Andreas E. Buss

\title{
The Economic Ethics of World Religions and their Laws
}

An Introduction to Max Weber's Comparative Sociology 


Andreas E. Buss

\section{The Economic Ethics of World Religions and their Laws}

An Introduction to Max Weber's Comparative Sociology 
Die Deutsche Nationalbibliothek lists this publication in the Deutsche Nationalbibliografie; detailed bibliographic data are available on the Internet at http://dnb.d-nb.de

ISBN

$$
\begin{aligned}
& 978-3-8487-2424-6 \text { (Print) } \\
& 978-3-8452-6583-4 \text { (ePDF) }
\end{aligned}
$$

\section{British Library Cataloguing-in-Publication Data}

A catalogue record for this book is available from the British Library.

ISBN $\quad 978-3-8487-2424-6$ (Print)

978-3-8452-6583-4 (ePDF)

\section{Library of Congress Cataloging-in-Publication Data}

Buss, Andreas

The Economic Ethics of World Religions and their Laws

An Introduction to Max Weber's Comparative Sociology

Andreas Buss

$219 \mathrm{p}$.

Includes bibliographic references and index.

ISBN 978-3-8487-2424-6 (Print) 978-3-8452-6583-4 (ePDF)

\section{Edition 2015}

(c) Nomos Verlagsgesellschaft, Baden-Baden, Germany 2015. Printed and bound in Germany.

This work is subject to copyright. All rights reserved. No part of this publication may be reproduced or transmitted in any form or by any means, electronic or mechanical, including photocopying, recording, or any information storage or retrieval system, without prior permission in writing from the publishers. Under $\S 54$ of the German Copyright Law where copies are made for other than private use a fee is payable to "Verwertungsgesellschaft Wort", Munich.

No responsibility for loss caused to any individual or organization acting on or refraining from action as a result of the material in this publication can be accepted by Nomos or the author. 
To my grandsons Jona and Mika 



\section{PREFACE}

Max Weber is today perhaps the classic author in the cultural and social sciences, recognized by scientists in many subject areas and on all continents. But his widely felt intellectual presence has not eliminated wideranging discussions about his intentions and the foundations of his work. Many use his œuvre only as a quarry for concepts and ideas, unaware that only a coherent and systematic reading will penetrate to the foundations of his thought, open up its possibilities, but also its inner tensions.

This is particularly true with regard to his essays on «The Economic Ethics of World Religions» and to his much shorter writings on the laws of these religions, for they appear to be based on an inner contradiction. On the one hand, Weber insisted that only by specialization, by putting on blinders, so to speak, the scientist can achieve something that will endure. But, on the other hand, he wrote about religions and cultures and their legal systems - in India, China, Buddhism, ancient Judaism -, and he commented on other cultures - Islam, Orthodox Christianity, and occidental Christianity - about which he certainly could not claim much specialized knowledge. What characterizes his ouvre, however, is his approach: he proposed a refined and coherent method of comparative social study with a largely historical dimension which was intended to contribute to the understanding of the characteristics of Western culture even when he wrote about Asian cultures. At the same time he asked which attitude towards the world remains for Western man, and what kind of conduct and which price and sacrifices it requires.

Weber's questions are not self-evident for sinologists, indologists, semitists or historians of Christianity, and they are also new for scholars and students of comparative religions and of the comparative history of law. For Westerners they provide a wider than usual perspective. At the same time, Weber did not want to teach the people of Asia anything about how their cultures should develop. His approach allows people of all cultures to turn the mirror around and, while adapting Weber's approach to their perspective, to look at their own roots. May this book contribute to the dissemination of Weber's comparative macrosociological analysis and of his understanding of the peculiarities of Occidental rationalism. 



\section{TABLE OF CONTENTS}

$\begin{array}{ll}\text { ABBREVIATIONS } & 13\end{array}$

CHAPTER I INTRODUCTORY REMARKS

The Texts (15); What were Weber's intentions? (18); The Critiques (21);

Scientific Concepts and Points of View (25); Rationality and

Rationalisation (27); The Method of Analysis (29); A Short Outline of the Material (31)

CHAPTER II THE PROTESTANT ETHIC STUDIES 34

1. The Protestant Ethic and the «Spirit» of Capitalism of 1904/05 34

2. The Protestant Sects and the Spirit of Capitalism 40

3. The Anti-Critiques 42

4. The 1920 Version of the «Protestant Ethic» 44

CHAPTER III THE WORLD RELIGIONS AND THEIR ETHICS 48

1. Max Weber's Introduction 48

2. Confucianism and Taoism 57

The Patrimonial Domination (58); The Spirit of Confucianism (60);

Heterodoxies (61); Conclusion (63); The Result: Puritanism versus Confucianism (65)

3. Intermediate Reflection: Religious Rejections of the World and their Levels and Directions 
4. Hinduism and Buddhism

The Hindu Social System (76); The Hindu Spirit (78); Orthodox and Heterodox Salvation Teachings (79); Ancient Buddhism (82); Buddhism elsewhere in Asia (85); Excursus: Japan (87); Later Indian Developments (88); A Retrospective View on the Asian Cultural World (90)

5. Ancient Judaism

The Transcendent God, the berith, and the Prophets (93); Pariah People, Pariah Ethics, and Pariah Capitalism (95); Supplement: The Pharisees (98)

6. Islam

Islamic Patrimonial Domination (102); The «Spirit» of Islam (106);

Sufism and Conclusion (108)

7. Christianity

a. Ancient Christianity

The Roman Monarchic-Bureaucratic Empire (110); The Spirit of Ancient Christianity (111)

b. Eastern Orthodox Christianity

The Patrimonial State (116); The Orthodox Church (118); The «Spirit» of the Orthodox Church (119); Russian Old Believers (121); The Russian Sects (124); Result (126)

c. Occidental Christianity

The Institutional and Legal Transformations (127); The «Spirit» of Traditionalism and the Puritan Sects (133); The Characteristics of Modern Western Capitalism (136)

\section{CHAPTER IV THE WORLD RELIGIONS IN CONTROL TESTS}

1. Elective Affinity and Causal Adequacy

2. Adequate Causation according to v. Kries

3. Weber's Use of the Concept of Adequate Causation

4. Adequate Causation and «The Economic Ethics of World Religions» 
CHAPTER V THE WORLD RELIGIONS AND THE LAW

SECTION 1: MAX WEBER'S SOCIOLOGY OF LAW

Jurisprudence and the Sociology of Law (153); The Rationalisation of the Societal Spheres (155); Excursus on Eigengesetzlichkeit (159); The Rationalisation of the Law (160); The Carriers of the Rationalization of Law (166); The «England Problem» (168); Retrospective Considerations (171)

SECTION 2: LAW IN THE WORLD RELIGIONS

1. The Laws in Non-Occidental Cultures

China (174); India (176); Buddhist Countries and Japan (177);

Islam (179); Jewish Law (181); The Law within Russian Orthodoxy (183)

2. Canon Law

3. European Secular Law

Roman Law (187); Natural Law (188); Continental European Law (190); English Common Law (193); A Retrospective View of European Secular Law (194); 4. Coda on Modern Comparative Law (195)

\section{CONCLUSION}

1. The «Author's Introduction» as a Conclusion

2. Commentary

Science (201); Architecture, Art, and Music (202); Formally Rational Law and the Puritan Conduct of Life (204); The Contemporary Relevance of Weber's Comparative Sociology (206)

APPENDIX

BIBLIOGRAPHY 



\section{ABBREVIATIONS}

AC The Protestant Ethic Debate. Max Weber's Replies to his Critics 1907-1910. Edited and translated by D. Chalcraft, A. Harringston \& M. Shields. Liverpool University Press 2001

AJ Max Weber Ancient Judaism New York: The Free Press 1967

ASS Max Weber Gesammelte Aufsätze zur Soziologie und Sozialpolitik Tübingen: Mohr (Siebeck) 1924 (1988)

ASW Max Weber Gesammelte Aufsätze zur Sozial- und Wirtschaftsgeschichte Tübingen: Mohr (Siebeck) 1924 (1988)

CMW Max Weber. Collected Methodological Writings. Edited by H. H. Bruun \& S. Whimster, translated by H. H. Bruun, London : Routledge 2012

ES Max Weber Economy and Society New York : Bedminster Press 1968

FMW From Max Weber : Essays in Sociology Translated and edited by H.H. Gerth \& C. Wright Mills New York : Oxford University Press 1958

GARS Max Weber Gesammelte Aufsätze zur Religionssoziologie vol. 1 (1920); vol. 2 (Hinduismus und Buddhismus) 1921; vol. 3 (Das antike Judentum) 1920 Tübingen: Mohr (Siebeck)

GEH Max Weber General Economic History New Brunswick : Transaction 1981

HCP Max Weber The History of Commercial Partnerships in the Middle Ages Lanham : Rowman \& Littlefield Publishers, Inc. 2003

MWG Max Weber Gesamtausgabe Tübingen: Mohr (Siebeck) since 1984

PE Max Weber The Protestant Ethic and the Spirit of Capitalism. Translated by T. Parsons; London \& New York : Routledge 2001

PE 1 Max Weber The Protestant Ethic and the «Spirit» of Capitalism and Other Writings. Edited and translated by P. Baehr \& G. Wells. London : Penguin 2002

PE 2 Max Weber Kritiken und Antikritiken. Die protestantische Ethik II Gütersloh: Mohn 1978

PW Max Weber Political Writings (ed. By P. Lassman \& R. Speirs) Cambridge U. Press 1994

RC Max Weber The Religion of China New York/London : MacMillan 1951

RI Max Weber The Religion of India New York: The Free Press 1958

RSM Max Weber The Rational and Social Foundations of Music, Southern Illinois U. Press 1958

SAC Max Weber The Agrarian Sociology of Ancient Civilizations (transl. by R. I. Frank) London : New Left Books 1976

WG Max Weber Wirtschaft und Gesellschaft Tübingen: Mohr (Siebeck) 1972 



\section{CHAPTER I INTRODUCTORY REMARKS}

The German scholar Max Weber (1864-1920) left a wide-ranging oeuvre, including political and methodological essays as well as essays in the field of political sociology, the sociology of law, of economics, of religion and of music. Although some of his major publications remained fragments, the new German edition of his collected writings (MWG), including letters, contains more than forty volumes. Weber's work stands out by its combination of empirical research and systematic thought. What characterizes most of it is his comparative approach which includes his views of Western Antiquity and the Middle Ages as well as of the major Asian cultures. His studies of what he called the "world religions» are probably the most obvious and important example. In this introductory chapter the necessary foundations will be laid for the understanding and interpretation of Weber's comparative studies.

\section{The Texts}

«The Economic Ethics of World Religions» is the title of a part of Max Weber's Gesammelte Aufsätze zur Religionssoziologie (Collected Essays in the Sociology of Religion), Vol. 1-3, Tübingen 1920/21, a three volume publication which also contains his revised essays on the Protestant ethic and the Protestant sects. The essays on the world religions (mainly Confucianism, Hinduism, Buddhism and ancient Judaism) were originally published between 1915 and 1919 in the Archiv für Sozialwissenschaften und Sozialpolitik, a journal of which Weber was one of the editors. A year before his death in 1920 Weber revised and extended these earlier publications and started to publish them as a whole under the title Gesammelte Aufsätze zur Religionssoziologie.

Volume I contains a Preceding or Preliminary Remark (Vorbemerkung, translated, not quite correctly, by T. Parsons as «Author's Introduction»), the extended essay on «The Protestant Ethic and the Spirit of Capitalism» (originally published in 1904/05), and a revised version of an article entitled «The Protestant Sects and the Spirit of Capitalism». This is followed by the revised «Introduction» to the section on «The Economic Ethics of 
World Religions», then the substantially extended essay on "Confucianism and Taoism» and finally an «Intermediary Reflection». Volume II contains the slightly revised essay on «Hinduism and Buddhism», and Volume III contains «Ancient Judaism» and a short text entitled «The Pharisees».

Weber's early death prevented him from doing more, but readers of his letters, now published in the Max Weber Gesamtausgabe (MWG), will come to realize that his ambitions had gone further. He had also wanted to add studies on Islam and on Christianity (MWG II/9: 69-70) and, as an announcement of his publisher Siebeck in the fall of 1919 indicated, the depiction of Christianity was to be divided into ancient Christianity, oriental Christianity and occidental Christianity. ${ }^{1}$ In fact, after his tour of Asia Weber wanted to return to the Occident with a widened perspective and, as he also pointed out in the announcement, the object of all these completed and planned essays would be the question of the particular characteristics of the Occident and of the development of the European citizen. Today we can only draw some indications of what he might have written on the economic ethics of Islam and Christianity from some parts of his work which is traditionally known as Economy and Society (ES), particularly the sections on the sociology of religion, the sociology of domination and the sociology of law. These sections in Economy and Society were considered by Weber as complementary and explanatory to the collection of essays on the «Economic Ethics of World Religions». In particular the section on «The Sociology of Law» (Chapter VIII in ES) contains short paragraphs on the laws of all major world religions, including Islam). ${ }^{2}$

1 This announcement, prepared by Weber himself, has been quoted in Johannes Winckelmann: Max Weber's hinterlassenes Hauptwerk, Tübingen: Mohr (Siebeck) 1986, p. 45/46; now also in MWG I. 19, p. 28

2 According to F. Tenbruck (in his article of 1980 on the thematic unity in the works of Max Weber) the continuing insights of Weber's sociology cannot be found in Economy and Society, but in the sytematic chapters of the Collected Essays in the Sociology of Religion, namely the «Preliminary Remark», the «Introduction», and the «Intermediate Reflection», where the realization of the inner logic of religious ideas came to him. But it should not be forgotten that Weber himself saw the relationship between Economy and Society and the Collected Essays in the Sociology of Religion as complementary and explanatory, as clearly stated in the first footnote of the «Introduction» to the «Economic Ethics of World Religions» which, regrettably, has not been translated by Gerth and Mills in their volume From Max Weber. The editorial history of Economy and Society contains a number of disputes. A new controversy has flared up since its publication in five volumes in the Max Weber 
The Collected Essays in the Sociology of Religion have never been translated into English as a whole. Instead, separate translations which leave the reader unaware of the interrelations have been published of the various parts. The «Prefatory Note» or "Author's Introduction» which introduces the whole three-volume series and which at the same time sums up the results, has been included by Talcott Parsons with his translation of «The Protestant Ethic and the Spirit of Capitalism» in a separate volume. The «Introduction» and the «Intermediate Reflection» which are of major importance for the understanding of the theoretical structure of the argument, have also been published separately under partially new and misleading titles («The Social Psychology of World Religions» and «Religious Rejections of the World and their Directions» respectively) by Gerth and Mills in their From Max Weber: Essays in Sociology (FMW). The essay on "Confucianism and Taoism» has been translated and published separately by $\mathrm{H}$. Gerth under the misleading title The Religion of China and the essay on «Hinduism and Buddhism» has been translated and published separately by $\mathrm{H}$. Gerth and D. Martindale under the equally misleading title The Religion of India. The Sociology of Hinduism and Buddhism. No wonder, then, that the interrelations between these works which must be interpreted in each other's light, are often misunderstood in the English-speaking scholarly community.

Equally important, however, for the understanding of many reactions to Weber's writings among specialists of Asian studies is the poor quality of some of the translations. Some of them are a disgrace. ${ }^{3}$ Not only have most English translations been given new titles which do not reflect Weber's intentions, but passages of major importance have been subjected to major changes. One example should suffice here:

Indian scholars, especially if they were interested in modern development, have often taken exception to the following statement:

«It is quite evident that no community dominated by inner powers of this sort (caste order and karma theory - A.B.) could out of its substance arrive at the

Gesamtausgabe. What was known as Weber's sociology of law is now called «Die Entwicklungsbedingungen des Rechts» in MWG I, 22-3. (The developmental conditions of the law). Vide H. Orihara «From a torso with a wrong head to five disjointed body parts without a head» in Max Weber Studies 3,2 (2003).

3 A revealing article on the subject of the English translations of Weber's studies on world religions has been Kantowsky's Max Weber on India and Indian interpretations of Weber» in: Contributions to Indian Sociology (NS) vol. 16, no. 2 (1982) 
«spirit» of capitalism. It was also unable to take over the economically and technically finished form as an artifact, as occurred in Japan.There appeared here clearly and undoubtedly greater difficulties than in Japan.» (RI: 325).

If we compare this translation with the German original, we find that the statement «It was also unable to take over the economic and technically finished form as an artifact» simply does not appear in the German text. Therefore, a more correct translation would be:

«It is quite evident that no community dominated by inner powers of this sort could out of its substance arrive at the «spirit» of capitalism. Even the takeover of the economically and technically finished form as an artifact, as occured in Japan, encountered clearly and undoubtedly greater difficulties than in Japan...» (GARS II: 359)

Clearly, this passage expresses a very different idea from what the English reader, interested in modern development, is led to believe. In fact, the breakup of the closely interrelated essays into seemingly unrelated monographs and the plethora of incorrect or misleading translations of passages in Weber's essays have produced a certain lack of interest in Weber's general intentions, and it is therefore not surprising that many misunderstandings have arisen. For the moment we may leave aside the fact that an appropriate understanding of these essays is possible only on the basis of some knowledge of Weber's methodological writings and of his sociology of domination and of law.

\section{What were Weber's intentions?}

It was not Weber's intention to provide us with a well-rounded picture of major world religions, or with a series of monographs.

«The studies do not claim to be complete analyses of cultures, however brief. On the contrary, in every culture they quite deliberately emphasize elements in which it differs from Western civilization. They are, hence, definitely oriented to the problems which seem important for the understanding of Western culture from this view-point.» (PE: XL).

Weber knew that a more balanced presentation would have to add other features, but he was interested in certain features of religions from a definite point of view, namely how they related to economic rationalism of the type which has developed in the modern Occident. In other words, he studied Asian cultures only to the extent that he deemed necessary to find points of comparison with Occidental characteristics as all his questioning 
turned around the uniqueness of the West. Moreover, Weber was well aware of the sketchy charcter of these studies and of his inability to read the sources in their original language. If he published them nevertheless, it was because he thought that they might perhaps be useful as a supplement to the problems raised in the sociology of religion and in the sociology of economics. That studies of this kind or, in fact, of any kind, can never be «final», was obvious to him.

Before considering Weber's intentions in «The Economic Ethics of World Religions», it is necessary to remember his purpose in the essay on The Protestant Ethic and the Spirit of Capitalism. There he had analysed the economic impact and relevance of the Protestant ethic for the spirit of capitalism (as opposed to its economic determinedness), and he had not been concerned with the exact extent or degree of its cultural significance but only with a general elective affinity or perhaps with its causal adequacy (more on this in chapter IV).

But then he wrote at the end of his revised essay in1920, that he wanted to correct the isolation of his study on Protestantism which, as has been mentioned, originally appeared in 1904/05, and to place it in relation to the whole of cultural development (PE: 262). This may have meant that

1. he wanted to validate his PE thesis by means of comparisons or control tests (AC: 54$)$ and thus to ascertain that only in the Occident modern rational capitalism could develop from indigenous sources. But, while this was probably one of Weber's intentions, it was not the only one;

2. while he had earlier investigated the significance of ascetic Protestantism for the development of the modern capitalistic mentality, he would now want to reverse the point of view which he had taken in the Protestant Ethic and to investigate how religious ethics were in turn influenced by the totality of social conditions (PE: 125), for he thought that both interpretations are equally possible. In fact, in the «Economic Ethics of World Religions» both sides of the relationship are considered.

3. But there is more: the essays on the economic ethics of world religions are not limited to an investigation of the religious influences on the economy and on the economic influences on religious ethics, but they also contain investigations about the relationship between religion, economics, political domination and law. Why was there this extention of the topic area? As Wolfgang Schluchter has suggested, Weber had begun to realize, perhaps as a result of his comparative study in the sociology of music (RSM) which also touched on Asian music, that a 
particular kind of rationalism pervaded not only Western music but the whole of modern European culture. ${ }^{4}$ The subject matter of capitalism or of the capitalistic spirit thus turned into the more general subject matter of the development of modern Western rationalism, and this in many areas of life: not only in economic ethics, but also in the politicolegal orders. And thus, even in his essays on Asian cultures Weber wanted to come to grips with the particular kinds of rationality which he found in all areas of occidental social life, and he realized that his essays turned out to be «contributions to a sociology and typology of rationalism» (FMW: 324). Rationalism, according to Weber, exists in all cultures, but cultures have rationalized different areas of life. Weber wanted to explain the peculiarity of Occidental rationalism as compared to the forms of rationalism elsewhere. He thought, for instance, that Protestantism had rationalized an attitude of world domination, Confucianism had rationalized world adaptation and the Indian soteriologies had rationalized world renunciation. But, as will be seen, there was not only a certain kind of rationalization of world domination in the Occident, but also a certain kind of legal rationalization. This would have become clearer, if Weber had been able to complete a study on Christianity.

There is, however, a certain tension in these essays to the extent that they permit two different interpretations of the view which Weber had of the place of Western civilization in relation to the cultures of Asia. On the one hand, it can be said that Weber produced a typological comparative universal history or that he conceived his essays on the ethics of world religions as «contributions to the sociology and typology of rationalism». Here, Western rationalism is considered as simply one among many, so that, for instance, Confucian rationalism can be opposed to to Puritan rationalism. On the other hand, China and India are also viewed by Weber as impregnated by traditionalism, and this places Western civilization on a more advanced level of development. It is not easy to integrate these two views, even if it must be said that Weber looked towards the future of Western civilization with apprehension as he foresaw mechanized petrifaction and a lack of brotherliness. It cannot be stressed enough that We-

4 Weber's wife Marianne wrote that according to her husband the process of rationalization in the Occident moved on several tracks; it penetrated the economy, the law, the sciences and art and combined both theoretical and practical rationality (Max Weber. Ein Lebensbild, 1984, p. 348). English version p. 333/4 
ber's interest in rationality and in the typologies of rationalization did not imply a preference for the Western type of rationalization or a normative «ethnocentric» treatment of other cultures. Weber viewed Western civilization as diseased, a dead-end street or an iron-cage without escape which suffocates the individual and which certainly does not have anything to offer to other civilizations. To be convinced of this, one need only read the last pages of The Protestant Ethic and the Spirit of Capitalism: «For the last stage of this cultural development, it might well be truly said: Specialists without spirit, sensualists without heart; this nullity imagines that it has attained a level of civilization never before achieved»(PE: 124). 5

\section{The Critiques}

Essentially three kinds of critiques have been formulated with regard to Weber's ceuvre in the fields of Asian studies. The first kind is related to the so-called «Protestant Ethic thesis», supposedly contained in Weber's writings. Weber himself hoped that nobody would be so simplistic as to impute to him the thesis that «confessional membership alone would conjure up a specified economic development to a degree that Baptist inhabitants of Siberia would automatically become wholesale traders and Calvinistic inhabitants of the Sahara would turn into factory owners» (AC:34). In

5 On occasion it has been claimed that Weber's comparative sociology is a classical statement of sociological orientalism (in the sense proposed by Edward Said), implying a) the opinion of the superiority of the West over the more or less homogenous and immobile East, and b) the importance of internal factors and a disregard for the role of colonialism. The above quotation about «specialists without spirit» should take care of the first claim, and with regard to the second claim (the influence of colonialism) it can simply be stated that there is hardly any disagreement in the scholarly community about the distinctness of the European path prior to the advent of colonialism. A more detailed analysis of these arguments can be found in Mohammad Nafissi «Reframing Orientalism: Weber and Islam' in: Ralph Schroeder (ed.) Max Weber, Democracy and Modernization, London: MacMillan 1998

Moreover, it should not be forgotten that Said connected his concept of orientalism mainly to the practices of British colonialism whereas German orientalists (in the original sense of the term) on whom Weber mainly relied, were not tied to colonialism and were rather interested in religious ethics and world views. Vide Kippenberg (2005: 169) who mentions J. Wellhausen, a specialist of Judaism, I. Goldziher, an islamist, and H. Oldenberg, an indologist. 
spite of this, many Asian readers of Weber seem to have felt that they must either refute what they believed to be the «Protestant ethic thesis» or accept lack of development and stagnation for many years to come. Others, perhaps under the influence of functionalist interpretations of Weber's ceuvre, have tried to point to functional equivalents of the Protestant ethic or to capitalistic «strands» in their own countries or cultures. Weber himself never considered the issues of industrializing and modernizing less developed countries, at least not directly, and he certainly knew that the thesis about a relationship between Protestantism and capitalism was not his own, but almost as old as Protestantism itself. Only the characterization of this relationship was open to debate. While many Asian and Western authors have tried to prove that there is a potential for capitalistic developement in their region - in some regions proof is obviously not necessary any longer -, Weber would not have denied that possibility. Predictions of trends were abhorred by him; more than anyone else he foresaw the possibility of unexpected consequences of historical phenomena and actions and he would not have tried to predict a future of any kind.

The second kind of criticism is related to the interpretation of details which the simple advance of historical research and anthropological research would have made unavoidable. We may note, as examples for China, the too close identification of literati and gentry, or Weber's limited understanding of Neo-Confucian philosophy; and, as examples for India, some interpretations of Indian sects and of the bhakti movement. Many facts and details which have been made available by modern research, obviously were unknown in Weber's time and, as far as these new findings are concerned, Weber must be corrected. But Weber's arguments cannot be judged merely by the yardstick of what is historically true from today's point of view. His were arguments which formulated new questions and new problems. His purpose was different from that of the historian (of the historicist tradition) and of the modern ethnographer who consider all historical epochs and cultures as totally different and unique and who want to paint a picture «of life as it really was» (Ranke) or is. It is precisely here that the third kind of critique is often advanced.

The third kind of critique relates to questions of ethnocentrism and comparative sociology. The accusation of normative ethnocentrism or Eurocentrism cannot be raised against Weber because he certainly did not consider the Western world as superior to other cultures, but he had a heuristic ethnocentric perspective as he looked upon world history from a consciously Western standpoint in order to understand by constant com- 
parison the distinctiveness of the West's development. Max Weber's wife Marianne $^{6}$ wrote in the biography of her husband that the essays on world religions were contributions to the characterization of Western man and his culture. In fact, Weber's points of comparison and his concepts have an Occidental origin because the comparisons are made to better understand certain aspects of the Occident. For instance, central to the understanding of Weber's sociology of religions is the concept of theodicy which may have to be redefined in non-monotheistic contexts like India. Weber championed comparative research because, among other reasons, he believed that without comparisons it is impossible to arrive at causal explanations (always of a probabilistic nature) in history and social science. No matter how clear an interpretation appears to be from the point of view of meaning, Weber thought that it cannot, on this account, claim to be a causally valid interpretation. Rather, it remains a hypothesis; and, in order to determine the degree of probability of such hypotheses, it is, according to him, necessary to compare a large number of historical and contemporary events by means of «mental experiments». For example, in order to test the probability of his hypothesis about the Protestant ethic, Weber studied the world religions.

In fact, the motives for studying another culture than one's own can be manifold, but they can generally be divided into two categories. There are those who proclaim the desire to understand the other culture as such, out of pure curiosity perhaps or as a result of an attitude of escapism, the longing for a «better» political system or a «truer» religion or the intention to use the knowledge gained to better dominate that culture; and, on the other hand, there is the motive pursued by some who study a different culture to better understand their own. Men like Alexis de Tocqueville or Louis Dumont in France and Max Weber in Germany belonged to this second category. In Tocqueville's The Old Regime and the Revolution the centre of interest is France, although we learn a lot about England and Prussia. France is the positive case, the others are negative cases used for comparative purposes. But what makes England England and Prussia Prussia obviously cannot be discovered in a theory of France. Similarly, Louis Dumont in his Homo Hierarchicus on the Indian caste system wrote: «We (occidental man) must convince ourselves that the castes can teach us some-

6 Marianne Weber Max Weber. Ein Lebensbild. Tübingen: Mohr (Siebeck) 1984 (1926), p. 346; Engl. p.331 
thing about ourselves», and he continued: "what good is there in going to India, if not in order to discover how Indian civilization... represents a form of the universal?». ${ }^{7}$ To see our culture in its specificity, we must see it in perspective by contrasting it with other cultures. It is possible here to speak of heuristic ethnocentrism or eurocentrism, but not of normative eurocentrism.

This is precisely the purpose of comparative sociology as opposed to those scientific endeavours which purport to study the uniqueness of other cultures. ${ }^{8}$ We are dealing here with a philosophical question which is at the very heart of the debate between comparative "Weberians» and specialists in the various fields of Asian studies. In fact, the more one rationalizes one method or scientific approach, the more there is the likelihood that a tension is created with other principles of rationalization, with other scientific approaches.

But one can legitimately ask what Weber's approach can mean or give to a scholar from Asia who is not, in the last analysis, interested in the charcterization of Western man and culture, but rather in the tradition or in the more recent developments and styles of modernization of his or her own culture and conduct of life. It has been suggested that a scholar from Asia should look at the history of his country and should then ask the basic questions which Weber asked when he attempted to understand the European situation: Who are we? How did we get here? Where should we go? Weber's essays on India and China and his views on Islam and Ortho-

7 Louis Dumont Homo Hierarchicus. Essai sur le système des castes. Paris: Gallimard 1966, p. 14 \& p. 16.

8 There is a humorous Hassidic parable which was recounted by Heinrich Zimmer in Myths and Symbols in Indian Art and Civilization (Princeton U. Press 1972) and which describes well the way of comparative sociology: A rabbi of the name of Eisik lived in the ghetto of Cracow in Poland. He had several dreams which enjoined him to go to Prage where he should discover a hidden treasure beneath a bridge. Finally, he went to Prague and discovered that sentries guarded the bridge day and night. Therefore he did not venture to dig, but loitered around until a captain of the guards inquired whether he had lost anything. The rabbi recounted the dream that he had had and the officer stood back and laughed: «Poor fellow», he said, «what sensible person would trust a dream? Look, if I had been one to go trusting dreams, I should be doing just the opposite now.» And he recounted of a voice which had commanded him to search for a great treasure in the house of a rabbi in Cracow whose name was Eisik. The rabbi listened eagerly and then hurried straightway back to his home, dug in a neglected corner of his house and discovered the treasure which put an end to all his misery. 
dox Russia would then be no more than a quarry from which fruitful hypotheses can be extracted, although his method might still be useful Because of the undoubted impact of Western culture in Asia, Indian or Chinese or Muslim scholars may also ask themselves whether they agree with Weber's analysis of the West. Is Western civilization, which is in the process of penetrating the East, such as Weber sees it? If the answer is in the affirmative, then Weber's essays may also be of some value to Asians who are interested in precisely those aspects of their own culture which present the greatest contrast and the greatest challenge to the West, because these are aspects which Weber intended to stress. To be sure, this approach will not grasp the «essence» of any culture. At best, it will help to comprehend those aspects of it which are meaningful and important to the scholar at the given time and under the given circumstances. Science cannot do more.

\section{Scientific Concepts and Points of View}

It has been mentioned earlier that, according to Weber, whatever approach one chooses, one will not grasp the essence of any culture. In fact, there is no «objective» scientific analysis of cultural life (CMW: 113), independent of one-sided points of view. The scientist or scholar starts from an interest which may come from his cultural environment or his personal views and which directs his questions. This is unavoidable, but it is important to realize it. In his address «Science as a Vocation» Weber explained that science can lead the scholar to clarity about himself, his own stand and the subsidiary consequences of his choices which will likely occur (FMW: 151), but it cannot prescribe the values according to which one should live nor the point of view which directs one's scientific endeavours.

Reality is a multiple chaos or a «heterogeneous continuum» of an infinite number of facts or appearances which the scholar approaches from a precise perspective provided by certain values. As human beings are endowed with culture, they have the capacity to take a position, to evaluate the events and to consider certain aspects of reality as significant, Weber wrote (CMW: 119). In contrast to the situation in the natural sciences which reduce the empirical reality to laws, no law can inform the cultural scientist in what sense reality is significant as this is determined by the values or the meaning context in the light of which we look at any culture. Moreover, not only the questions which the scholar asks are tied to the 
values of his culture, but also the concepts which he formulates. In fact, Weber accepted the distinction of his philosopher-friend H. Rickert between generalizing (in the natural sciences) and individualizing concept formation (in the humanities). Concepts may be simply classificatory (as in Linné's classification of plants, formed according to the schema genus proximum, differentia specifica) and are then applicable to many cultural environments. They describe what is common to empirical phenomena. In this case they are likely to have fluid boundaries (such as «capitalism» which, according to Weber, has existed everywhere in the world and can be subdivided into adventure capitalism, political capitalism, tax farming etc.). But there are concepts like for instance «romantic» or «entrepreneur» or «modern capitalism» which it would be difficult to use in a classificatory way. In fact, the more we are dealing with the conceptual shaping of complex historical relationships which are culturally significant and are related to a particular culture and epoch, the more the concepts will have the character of ideal types of an individual character, although some classificatory characteristics are also assumed to exist. They will be used for heuristic purposes which accentuate unilaterally a point of view in order to understand a section of reality in its significance for modern culture. They will not be intended to grasp any «substance» or «true» reality (CMW: 127); rather, they will diverge from empirical reality which can only be compared or related to them. If for example the scholar takes the concept of sect, he can try to understand the meaning context of the religious dogma which predominates in sects and form it into a homogenous thought-out structure towards which all sects or sect members must strive if they take the logical consequences of their confession seriously. ${ }^{9}$ The aim of this ideal-typical concept formation is always, according to Weber, to bring out the individualising aspects and not what is general in cultural phenomena. Weber's «Protestant ethic» also is such an ideal type, a «historical individual», as it accentuates those aspects which were significant for modern culture. Many other concepts which Weber used are also ideal types, and their use implies several things:

1. They never describe the substance or the essence of reality which rather is characterized by the infinity of its aspects.

9 Dieter Henrich Die Einheit der Wissenschaftslehre Max Webers Tübingen: Mohr (Siebeck) 1952, p 93 
2. They are the result of a utopian construction which can never be found as such in empirical reality.

3. This utopian construction should not be confused with an ideal. It is simply the result of a unilateral choice of certain factors in reality which seem to be significant to the researcher from his point of view.

The one-sidedness and also intensification of certain aspects of reality gives coherence to the ideal type while reality itself is much more unstructured and confuse. The scientific task is then to estimate to what extent the empirical data approach the ideal type.

As for the rest, Weber's theory of science implies that it is impossible to construct a complete and definitive synthesis of reality. We are necessarily limited to partial views, and other ideal types regarding the «same» relity are always possible and will in fact be constructed as soon as «the light shed by the great problems of (our) culture moves on» (CMW: 138). ${ }^{10}$

\section{Rationality and Rationalisation}

Among the ideal-types which Weber used in order to project a mental order unto the «chaos» of reality of Western society were, of cause, capitalism, and then the process of rationalisation which, according to him, had penetrated all the spheres of Western social life: not only economics, but also religion, law, and even music. When Weber published his essay on the Protestant ethic in 1904/05, he tried to establish an elective affinity between the ethics of certain Protestant groups and the «spirit» of capitalism. But, as has been mentioned earlier, when he published the augmented essay in 1920, his interests and preoccupations had become wider and, as he explained in the «Preliminary Remark» of the Collected Essays, capitalism had become for him only an aspect of a more general process of rationalisation. Rational scientific research practiced by specialists, rational bureaucracy, the corner stone of the modern state, rational harmonic music, a rational juridic doctrine, a rational organization of business with rational accounting and based on the existence of formally free labour - all of these are examples of the specific rationalism of Western civilization.

10 Weber's reflections on the ideal type can be found in his «The robjectivity of knowledge in social science and social policy» (CMW: 100-138). 
One must remind oneself that Weber repeatedly insisted that the term rationalism or rationalisation may refer to extremely diverse things and that the areas of social life as well as whole civilizations may be rationalized in regard to very different ends and values. What is rational from one point of view may become irrational from another standpoint so that, for instance, for the unbeliever every religious way of life is irrational. It is possible to talk of the rationalisation of mystical life in India although this kind of life may be considered irrational from our economic point of view. Even magic can be rationalised and systematised, for the first therapeutics which may be considered rational implied the refusal to treat empirical symptoms by potions and rather tried to get rid of the presumed «true causes» of an illness by exorcism. Nevertheless, Weber tried to find the distinctive characteristics of Western rationalism and then to analyse the different forms of modern rationalism

The rationalisation of life in the Occident does not imply a collective or individual progress; it is not an ideal but rather an ideal-type which Weber used to structure reality. Living in modern rationalised society human beings have not become less aggressive, and they have not always become more free. On the contrary, rational modern bureaucracy encloses us, according to Weber, in an «iron cage» which drove him to despair. Similarly, there has perhaps been rational progress in the technique of painting since the discovery of the perspective, but this does not imply that primitive art was less beautiful. But rationalisation implies an increase, a specialization and a systematization of knowledge on the societal level. Although it may be true that the passengers of an air plane or the users of a computer do not normally know the principles of their functioning, they know that they could learn them if they wanted, and that there are no mysterious magical forces in this machinery which cannot be mastered. To the extent that modern man has ceased to believe in magical forces, the world has become «disenchanted», in Weber's terminology, and there is the belief in the calculability of all events.

Rationalisation can appear in several forms: There is, of course, the scientific and technical rationality, but in his essays on the world religions Max Weber was mainly concerned with practical rationality, referring to orientations in the conduct of life and to the ensuing kinds of personality; he was also concerned with metaphysical rationality which is the consequence of the need of man to understand the world as a coherently structured cosmos which has a meaning. In his sociology of law Weber was concerned with the institutional orders of life, and there he distinguished 
between formal and substantive rationality. Weber thought, though, that there is an inevitable tension between certain kinds of rationalism and that if, for instance, one produces more rationality in the scientific or technical sphere, the rationality on the metaphysical level - the meaning structures of the cosmos as a whole - will diminish. Moreover, Weber was also aware of the limits of rationalism and that the rational in the sense of inner consequence, although it may have power of man, is always limited and unstable (FMW:324) and he pointed to the fact that the rationally most coherent solutions often collide with the «injustices of the world» (FMW: 275/6).

\section{The Method of Analysis}

All social phenomena have, according ot Weber, an exterior and an interior side. To the exterior side belong the economic, political, and legal circumstances which can affect peoples» situation in a positive or negative way. The inner side refers to the disposition of humans to lead a certain rational conduct of life. With regard to capitalism Weber distinguished between the capitalist system or form (the exterior side) and the capitalist spirit (Geist, the inner side). ${ }^{11}$ By system or form he meant the capitalist organization within a formally rational and predictable legal system, the technically rational means of production, double entry accounting, the separation of household and enterprise, and free labour; by spirit of capitalism he meant a methodical-ethical conduct of life in one's profession and a rational tempering of the irrational impulse of gain. The form of capitalism had totally different origins than the spirit, but both may exist in close affinity (Wahlverwandtschaft) with each other even if the form would have been unable to produce the spirit out of itself. In the answers to his critics (AC) Weber pointed out that a capitalist spirit has sometimes existed without a capitalist system, and a capitalist system without a capitalist spirit - in the same way as we might find an army organized according to the German model of an army but without a militaristic spirit. A historically given form of capitalism, Weber wrote, can be filled with very different kinds of «spirits» which may have varying degrees of affinity with the

11 The opposition of spirit and form had already been used by Nietzsche in the first part of his Unzeitgemäße Betrachtungen where he wrote about the defeat if not the extirpation of the German spirit for the sake of the German Reich after 1871. 
form (favorable, indifferent, or even obstructive). But when the form or system and the spirit have a particularly high degree of affinity, a development of unbroken homogeneity is likely to commence. If, however, the degree of affinity is low, there will be tension between the economic system and the spirit, the ethical life-style, as was the case in Florence (AC: 49 , fn.2)

Western man lives today, according to Weber, in an iron cage (Talcott Parson's translation of stahlhartes Gehäuse), namely the shell or form of capitalism from which the spirit has escaped long ago (PE: 123). With regard to India, Weber talked of the «spirit» of the whole system (RI: 112), and he also mentioned the shell (Gehäuse), namely the caste system (RI: 121); with regard to China, Weber wrote of the firm shell (festes Gehäuse) of patrimonial bureaucracy (RC: 61) which was the seat of the "spirit» of the literati and of Confucianism (RC: 129; 203). There can be little doubt then that any study of the development or the diffusion of capitalism, modernization, or industrialization in Asia, if it claims Weberian roots or a Weberian frame of reference, must specify whether it refers to the inner «spirit» of these phenomena or simply to the outer form or structure. The diffusion of and the adaptation to the outer form of capitalism or modernization or of a Western legal system is one thing, the development of the «spirit» from within is quite another. This is particularly so because Weber saw affinities not only between the capitalist system and the capitalist spirit, but also between the occidental politico-legal system and its worlddominating spirit.

As already mentioned, Weber distinguished between the exterior system and the inner spirit in all world religions. With regard to the spirit, a further comment is necessary, for it is not simply a shorthand term for religious foundations or dogmas, constructed in a coherent way by intellectuals or theologians. Besides the constructed dogmas there are always also the salvational interests and psychic reactions of the faithful. Religious ideas have an influence on the course of historical development only through the interaction between them and the salvational interests of the believers or the psychological premia which they hope to attain. It is this interaction which produces the spirit. Weber repeatedly pointed to the fact that while the doctrines of the theologians may well require a certain kind of conduct, for instance frugality and hard work, these doctrines do not necessarily create in the people the psychological motives which will produce the required type of conduct. Nor do worldly wisdom or the doctrines of the literati create such motives. Catholic doctrine, for instance, insists 
on hard work, but the highest premia which the Catholic can attain are the result of other kinds of conduct, and there is, moreover, in the confession a means to relieve one's conscience. Protestantism, on the other hand, sets a very high psychological premium on the methodical conduct of life in providing the idea that only by proving oneself in one's life and vocation can one attain the inner reassurance of salvation (certitudo salutis).

Weber's insistence that he is concerned with the psychological sanctions created by the religious and institutional context, and not simply with the theories of theologians and literati, must be kept in mind by anyone who wishes to find equivalents of the Protestant ethic in Asia. The analyst needs sources of the respective religious foundations as well as of the salvational interests of religious communities. It must be conceded, though, that Weber used both types of sources in the Protestant Ethic, but that in the essays on the world religions he often contented himself with an analysis of the dogmatic foundations.

\section{A Short Outline of the Material}

Chapter II is concerned with Weber's Protestant Ethic studies. It provides a summary of the original version of 1904/05, followed by a summary of Weber's article on the Protestant sects. Furthermore, there is a section on Weber's replies to his critics in the years following the original publication, and, finally, a short analysis of the main additions which Weber introduced in the 1920 version of the Protestant Ethic.

Chapter III provides summaries and commentaries of Weber's published essays on the economic ethics of world religions (China, India/ Buddhism and ancient Judaism) as well as Weber's views of the economic ethics of those world religions on which he was unable to publish complete essays (Islam, ancient Christianity, Orthodox Christianity and Occidental Christianity). In some cases, when Weber's analysis seems too sparse from today's point of view and knowledge, short additions have been inserted in accordance with Weber's general trend of thought. All of this is, of course, preceded by Weber's «Introduction» and augmented by his «Intermediate Reflection». The analysis of each world religion is divided into parts: 1 . the sociological foundations (the political and administrative system), 2. the religiously motivated orientation of life of the religious carrier groups, 3. the distinction between orthodox and heterodox movements, and 4 . the distinction between elite and mass religiosity in the 
respective religious tradition. With regard to each religion the major critiques which have been addressed to Weber's essays and views are pointed out and commented upon in extended footnotes.

Chapter IV intends to show how Weber's comparative studies of world religions serve as «indirect causal validation» of Weber's Protestant ethic thesis. It starts with an analysis of the concept of «elective affinity» and shows that it can be divided into two aspects: adequacy on the level of meaning and causal adequacy. Whereas Weber's Protestant Ethic shows mainly an adequacy on the level of meaning between the Protestant ethic and the spirit of capitalism, his essays and views of the economic ethics of world religions try to establish a causal adequacy. They verify and validate the PE-thesis, they also suggest an adequate causal relationship between certain kinds of sects in other cultures and a generalized concept of capitalism, they exclude other theories related to technical advances, precious metals, population increases etc., and they finally underline the power and efficacy of religion in the formation of cultural and social phenomena.

Chapter V is to a certain extent the counterpart of chapter II. Whereas in chapter II the Protestant ethic, the inner side or the spirit of Western development, is analyzed, chapter $\mathrm{V}$ analyzes the exterior side and particularly its main aspect, the law.

The first section is merely an introduction to Weber's sociology of law. It shows the distinction which Weber makes between the sociology of law and jurisprudence; and it then disusses four kinds of law, based on Weber's distinctions between rational and irrational as well as between substantive and formal law. There are, moreover, two kinds of formally rational law: English common law and continental European law, based on codes. The developmental conditions of the rationalisation of law can largely be derived from its inner logic and from its carrier groups.

The second section provides a short outline of the legal ideas and systems within all the cultures which were considered in chapter III. Weber's own observations are left intact but are often complemented and, as in the case of Buddhist and Russian-Orthodox law, completely new observations have been added with Weber in mind. Again, the critiques addressed to Weber and recent advances in scholarship have received some comments in the footnotes. The center of this section, however, is the development of European secular law. In the comparison with Confucian, Indian, Buddhist and Islamic legal concepts and ideas, the particular characteristics of the 
modern Occidental legal structures, their unique formal rationality, becomes visible.

Although Weber had integrated some considerations of the respective laws in his essays on India and China, it has seemed preferable here to reconsider these laws in a separate chapter, based mainly on his «sociology of law» in Economy and Society, in order to clearly establish the difference between Western and Asian laws and also to clearly characterize Western law as an exterior counterpart of the interior spirit of capitalism.

In the Conclusion, Weber's Preliminary Remark («Author's Introduction») is examined and interpreted. After viewing the panorama of the other world religions and their laws, Weber's focus, saturated with comparative information, returns to his original question about the distinguishing features of the West (of his time), he describes briefly the rationalisation which took place in Western science and music, and then points to the particular kind of rationalisation which took place in Western law and in the Western «spirit», as well as to the elective affinity which combined and strenghtened them. It becomes apparent, though, that Weber had an ambivalent attitude to all these kinds of rationalisation. 


\section{CHAPTER II THE PROTESTANT ETHIC STUDIES}

\section{The Protestant Ethic and the «Spirit» of Capitalism of 1904/05}

\section{Basic Literature}

Max Weber The Protestant Ethic and the "Spirit» of Capitalism and Other Writings (edited and translated by Peter Baehr \& Gordon Wells) London: Penguin 2002

Max Weber «Die protestantische Ethik und der 〈Geist〉 des Kapitalismus» in: Archiv für Sozialwissenschaft und Sozialpolitik 20 (1904) pp 1-54 and 21 (1905) pp. 1-110

Max Weber noted in the «Introduction» to his essays on «The Economic Ethics of World Religions» that he assumes that the reader has knowledge of his studies on Protestantism. Let us therefore turn to these studies and start with his essay «The Protestant Ethic and the «Spirit» of Capitalism» as it appeared in its original version of 1904/05.

A glance at the occupational statistics of European countries of mixed religious composition brings to light, according to Weber, the mainly Protestant character of capital ownership and a reduced participation of Catholics in modern business life. Weber believes that the prevailing explanations of his time which underline the «other-worldliness» of Catholicism and the «materialism» of Protestantism are not tenable. On the contrary, it might be possible to see an affinity between other-worldliness and Protestant asceticism on the one hand and capitalistic acquisition on the other. Already the Spaniards of the seventeenth century knew that the «heresy» of Calvinism promoted the desire for trade, and the Quakers and the Mennonites became rich although no joy of living can be ascribed to them. Indeed, the affinity between certain aspects of Protestantism and the modern capitalistic culture does not seem to lie in its alleged joy of living but rather in certain religious characteristics. 
What is to be understood by the «spirit» ${ }^{12}$ of capitalism? Weber does not provide a definition but rather an illustration. The writings of Benjamin Franklin are evidence of an ethos: the obligation which the individual feels to work with prudence and honesty for the increase of his capital as an end in itself. The summum bonum (the highest good) of this ethic, the acquisition of more and more money while avoiding all spontaneous enjoyment of life, is completely devoid of any hedonistic or eudaemonistic aspects.

The outer form of an economic order and the spirit which lives in it or in the people can find themselves in some sort of adequate relationship to each other (but not in a relationship of necessary interdependence). When Weber used the expression «spirit of capitalism» to describe that style of life which seeks profit rationally and systematically (like Benjamin Franklin), he felt that this was justified by the historical fact that this attitude or spirit has found its most adequate form in the capitalist enterprise.

But the capitalistic spirit and the capitalist form or order may well occur separately. At the beginning of modern times capitalistic enterprises were often led in a traditionalistic spirit. When this spirit, in some cases, turned into a capitalistic one, this was interpreted by others as the result of the auri sacra fames (greed for gold). For the idea of money-making as an end in itself, as a calling, was contrary to the ethical feelings of the Middle Ages and, in fact, of most epochs; money-making was at best considered as ethically indifferent, it was tolerated, but deo placere vix potest (it was not thought to be pleasing to God).

How, then, did the idea of gain in Franklin's sense grow out of traditionalism and how can the affinity between the spirit of capitalism and certain religious characteristics of the Reformation be illustrated? The de-

12 The term «spirit» was fashionable in Weber's time. One of Nietzsche's books was entitled The birth of tragedy from the spirit of music, and v. Ihering had written The Spirit of the Roman Law. The use of the term can be traced to the eighteenth century when the French esprit de siècle turned into Herder's Volksgeist. (spirit of a people) and then, in the nineteenth century, into Hegel's Weltgeist (world spirit). Geist (spirit) was for Weber the quintessence of values, motivations and goals of the dominating strata of a society and also something related to style. In the PE:17 Weber described the capitalistic spirit as an «ethos in the sense of an ethically coloured maxim for the conduct of life» and in his so-called anticritical writings (AC: 64) he added that it is a habitus or a conduct of life within the orders of the world (as opposed to an ethos of monks) which is characterized by matter-of-factness, calculability, rational consequence and specialization. 
velopment of this new conduct of life and of a calling which is completely irrational from the point of view of purely eudaemonistic self-interest, needs to be traced.

Before the development from traditionalism to the modern capitalistic spirit is analysed, Weber interjects some methodological remarks. The founders of the Protestant religious movements did not intend to promote what has been called the spirit of capitalism. To the extent that they contributed to it, it was the unforseen and even unwished-for result of their labours. ${ }^{13}$. Besides, Weber's inquiry is limited to the question of what in modern culture which is itself the result of innumerable different historical factors, can be imputed to the influence of the Reformation. Therefore, there is no intention of maintaining that the spirit of capitalism (or even the capitalistic system) could only have arisen as the result of certain effects of the Reformation; rather, it will only be ascertained whether and to what extent religious forces have taken part in the qualitative formation and in the quantitative expansion of that spirit throughout the world. This will be done first by ascertaining at what points certain elective affinities between forms of religious beliefs and practical ethics (Berufsethik) can be recognized. In this way it may be possible to clarify the manner and the general direction in which the religious movements have influenced the development of economic life. Afterwards, one could attempt to estimate to what extent modern culture can be attributed to religious motives.

The German word Beruf as well as the English word calling, in its modern meaning among the Protestant people, has its source in the Bible translations as the result of the spirit of the translators, not that of the original text. The meaning of the word - a life-task, a definite field of work -, took on a new colour: the valuation of the fulfilment of duty in worldly callings as the highest goal which the moral activity of the individual can achieve. The Catholic division of ethical precepts into praecepta (commandments for lay people) and consilia (supererogatory recommendations for monks) was discarded. To surpass worldly actions in monastic asceticism had become impossible: for Luther, the fulfilment of innerworldly duties was the

13 Here, as quite often in Weber's writings, the reader is reminded of an aphorism of the German writer and poet J.W. Goethe whom Weber knew well: «Everything that we do has a consequence. But wise and just actions do not always produce something favourable. and wrong actions do not always produce unfavourable consequences; on the contrary, just the opposite sometimes happens.» Goethe to Eckermann, 25 december 1825. 
only way of living acceptably to God. But as Luther insisted on the sola fide (justification can be achieved only by faith), his concept of calling remained traditionalistic, and one's calling and status were things which man had to accept as a divine ordinance, to which he must adapt himself. Moreover, mystical influences played a role in Luther's thought. The idea of calling in the Lutheran sense is, therefore, of questionable importance for the development of the conduct of life which concerns Weber in his Protestant Ethic.

A very different relationship between religious life and worldly action in a calling can be found in Calvinism to which Weber now turns. Here, without any doubt, the doctrine of predestination was of particular cultural and historical significance. By God's absolutely free decree, and without human merit or guilt playing a role in it, one part of humanity is saved, the rest is damned. To apply earthly standards of justice to God's double decree is meaningless in the context of this doctrine. In this situation nobody can help, no priest, no sacraments, no Church and no God (Christ had died only for the elect) and the individual is torn away from the close ties with which he was bound to the community. The consequence of this doctrine was a disillusioned individualism and it would have led to fatalism without the development of another doctrine and other ideas and motivations. Weber can show these motivations as he is less concerned with the question of what was theoretically and officially taught in the ethical compendia of the time than with the psychological motivations which originated in religious belief and practice.

It seems at first an enigma how the superiority of Calvinism in social organization could combine itself with this tendency to tear the individual away from the closed ties which bound him to this world, but a comparison with Luther's thought can clarify the issue. In Calvinism the Lutheran unio mystica, in which the soul is thought to be the vessel of the Divine, was impossible. Because of the absolute transcendency of God (finitum non est capax infiniti, i.e. finite man is incapable of grasping the infinite), the community with God could only take place to the extent that man's actions were influenced by God, that man felt himself to be the tool of God, a tool in maiorem Dei gloriam (to the higher glory of God), God's tool to dominate the world by work in one's vocational calling.

Moreover, Calvinism added to the doctrine of predestination the idea of proving one's faith and election in worldly activity and it thus provided a positive incentive to innerworldly asceticism. Although good works and an ascetic lifestyle were not considered to be the means of attaining salva- 
tion, they were indispensable as a sign of election - on condition that they were not simply individual good works but the result of a unified and systematic conduct of life. This idea of proof as a psychological basis for a methodical way of life can be studied in its purest form in connection with the doctrine of predestination, but it is a recurring framework for the understanding of the connection between faith and ethical conduct not only in Calvinism, but also in other Protestant denominations.

The monastic rules of the Benedictines, the Cistercians and even more the Jesuits had all rejected any planless otherworldliness and had developed a systematic method of rational ascetic conduct; they had brought the monks' actions under constant self-control and had turned them into workers in the service of God. And, as Weber mentioned, it is the paradox of all rational asceticism that it creates the very wealth that it rejects, that monasteries become the very loci of rational economies and occidental monks the first men of vocation (Berufsmenschen). But what was new after the Reformation was the fact that one was now forced to work in a calling and to pursue ascetic ideals within mundane occupations. Christian asceticism had slammed the door of the monastery behind it and strode into the world (PE: 101). While the monks had practiced an outworldly ascesis in conformity with the consilia evangelica ( in Catholicism the recommended ascetic life-style of monks), now every Protestant had to lead an ascetic life in the world.

Lutheranism did not yet create the same motivations for a methodical regulation of one's life and the non-Calvinistic ascetic movements, considered purely from the view-point of the religious motivation of an ascetic and methodical conduct of life, formed an attenuation of the inner consistency of Calvinism. In Pietism, one finds a greater emphasis on the emotional side of religion; it practically led its followers to strive for the enjoyment of salvation in this world rather than to engage in the ascetic struggle for certainty about the future. The doctrine of predestination was tempered by the doctrine of «terminism» (grace is offered by God once only). In comparison with Calvinism one finds a lesser intensity of the methodical conduct of life. The dogmatic theory, for instance in Spener, lacked consistency, as he was influenced by mysticism.

Also the Methodist ethic appears to have rested on a foundation of uncertainty and inconsistency. The aspiration to the «second blessedness» served as a sort of substitute for the doctrine of predestination. The Baptist movement, finally, and the sects which adopted its religious thought (the 
Baptists, Mennonites and Quakers) is an independent source of Protestantism.

On the whole, in the non-Calvinistic Protestant movements the religious community was no longer looked upon as a sort of trust foundation, including both the just and the unjust, for supernatural ends, whether for increasing the glory of God (Calvinistic) or for bringing the means of salvation to men (Catholic and Lutheran), but solely as a community of personal believers and of the reborn. In other words, not as a church but as a sect. All Baptist communities desired to be pure in the sense of the blameless conduct of their members. They could also be characterized by the expectant waiting for the «inner light», but with time an accommodation took place to worldly activity in a calling. Their attitude implied a weakening of the Calvinistic conception of the calling although the intensity of interest in economic occupations was considerably increased by their refusal to accept office in the service of the State.

The decisive point in all Protestant denominations was the conception of the state of religious grace which could not be attained or guaranteed by any magico-sacramental means, by a confession or by any individual good works but only by proving oneself in a specific type of conduct. From this followed for the individual the incentive methodically to verify his own state of grace in his practical conduct, a rational planning of the whole of one's life in accordance with God's will.

After having shown the religious foundations of the Puritan idea of the calling ${ }^{14}$, Weber examines the effects of this idea in the business world. Since English Puritanism which grew out of Calvinism gives the most consistent religious basis for the idea of the calling, he places the writing of one of its representatives, Richard Baxter's «Christian Directory», at the centre of the discussion.

There is a continually repeated passionate preaching of hard, continuous bodily or mental labour; waste of time is the deadliest of sins; the real moral objection is to the relaxation in the security of possession; what God demands is not labour in itself, but rational labour in a calling, although a change of calling is not objectionable. While successful work is proof of salvation, to strive for riches in order to live well is sinful.The spontaneous enjoyment of life is rejected whereas the specialized division of

14 Only in passing Weber mentions another cultural influence of Puritanism: It is, according to him, one of the fathers of modern military discipline (PE: 196). 
labour is ethically justified. The ascetic compulsion to save while living frugally leads to an accumulation of capital. Weber also underlines the pharisaically good conscience of the Puritans in the acquisition of money. Every trace of the Deo placere vix potest (the Catholic idea that the accumulation of wealth cannot please God) has disappeared.

Although the ascetic literature of almost all religions is saturated with the idea that faithful labour is pleasing to God, the Protestants deepened this idea and created the psychological motives for it which alone are decisive: the conception of labour as a calling and as the best, often the only means of attaining certainty of grace. It may therefore be said that one of the fundamental elements of the spirit of modern capitalism: rational conduct on the basis of the idea of the calling, was born from the spirit of Christian asceticism.

Already Goethe expressed the idea that the limitation to specialized work and the renunciation of the Faustian universality of man is a precondition of any valuable work in the modern world. The Puritan, as Weber said, wanted to work in a calling while we are forced to do so. Routinization has set in and the spirit which was under discussion here, today has left the «iron cage» of the capitalist system; the victorious system no longer needs its support in order to determine with irresistible force the lives of all those who are born into it. At the end, Weber asks with Nietzsche whether mechanized petrifaction is about to paralyse us or whether we are about to become specialists without spirit or sensualists without heart.

\section{The Protestant Sects and the Spirit of Capitalism}

\section{Basic Literature}

«The Protestant Sects and the Spirit of Capitalism» in From Max Weber. Essays in Sociology. (translated and edited by H. H. Gerth \& C. Wright Mills) Oxford 1958 pp. 302-322

«Die protestantischen Sekten und der Geist des Kapitalismus» in Max Weber Gesammelte Aufsätze zur Religionssoziologie vol. 1 Tübingen: Mohr 1920, pp. 207-236

While in the essay on the Protestant Ethic Weber had considered only one of the factors which had contributed to the conduct of life in the worldly activity of a calling, the essay on the Protestant sects provided the opportunity to consider another factor: the influence of religious institutions and 
communal forms, i.e., the external conditions rather than the inner motivations, which contributed to the conduct of life of the Protestants.

The distinction between church and sect is relevant here. A church is an institution of sacramental grace, membership is obligatory for all and does not prove anything with regard to the members' qualities; a sect is a voluntary association which one can only join after a religious probation. Membership in a sect signified that the person involved had certain moral qualifications and it especially certified a certain level of business morals. It was particularly important for the conduct of life of the members of a sect that the congregation as a self-governing and sovereign local community was jointly responsible for keeping unworthy individuals away from participation in the Holy Communion, that the congregations were small enough in order to guarantee church discipline and that the administration of church discipline was vested in the hands of lay people. A member, before he was allowed to join, had to have certain qualities which happened to be important for the development of modern rational capitalism, and then he had to prove repeatedly within the circle of his sect that he was endowed with these qualities, that he was worthy of being a sect member. There is, according to Weber, no stronger means of producing a desired conduct of life than through the necessity of holding one's own in the circle of one's group if one's whole existence in this world depends on «proving» oneself to its members, certainly much stronger than if in a church one can obtain forgiveness.

Membership in a sect had an influence on credit-worthiness, for the «children of the world», so it was said, distrusted one another in business but they had confidence in the religiously determined honesty of the pious, controlled by sect discipline.

The predominance of clubs in American society is largely the product of a process of secularization of these voluntary religious associations, the sects. Until relatively recent times it has been important, if one wanted to succeed in business, to be recruited by ballot as a member of a sect, a club or an association. 


\section{The Anti-Critiques}

\section{Basic Literature}

The Protestant Ethic Debate. Max Weber's Replies to his Critics 1907-1910 (edited and translated by D. Chalcraft, A. Harrington \& M. Shields) Liverpool University Press 2001

Max Weber Die protestantische Ethik II. Kritiken und Antikritiken (edited by J. Winckelmann) Gütersloher Verlagshaus 1978

In his replies to the critics of his Protestant Ethic essay during his lifetime Weber attempted to clarify once again some often misunderstood points. He underlined in particular that he had never thought of identifying the economic system of capitalism with the capitalist spirit, and he stressed that it is quite possible in the study of history to find at certain times the capitalist spirit without the capitalist economic system, while at other times one may encounter the capitalist system without a capitalist spirit (AC: 71 ) - just as it is possible to have an army which is organized according to the Prussian model but without a militaristic spirit (AC: 94).

The distinction between, on the one hand, a system or form and, on the other hand, a «spirit» which lives in this form, was central for Weber. When, as he said, the capitalist economic system was at its highest point of development in Italy before the Reformation, a capitalist spirit in his sense of the word was absent. Rather, among serious men there was the feeling of a profound tension between the economic system and the ethical conduct of life, or between action and conscience, with all the compromises which resulted from the conviction that economic efforts are not pleasing to God (deo placere non potest) AC: 74). Even today capitalism as a system may exist comfortably without a capitalist spirit as a fatalistically accepted necessity.

A historically given form of capitalism, Weber said, can be filled with very different «spirits» and can have very different levels of elective affinity with a historically given spirit. Form and spirit can be in a relationship of high or low adequate affinity or even without any adequate affinity. There is no doubt that the level of adequacy is not without influence on the historical course of development and that in those cases when a system and a spirit of high adequacy or elective affinity meet, a development of high inner homogenousness sets in (AC: 75).

Such a high elective affinity was present in the economic development of the seventeenth and eighteenth century when the great inner tensions 
and conflicts which often exist between professional life and ethics, were adjusted and reduced by Puritanism in a characteristic way and in a geographical area where the traditions of Antiquity and of the Middle Ages pointed to different directions and where today again, as Weber believed (AC: 73), we experience cultural tensions of the highest order.

Weber rejected the foolish idea that the Reformation alone has created the capitalistic spirit or even capitalism as an economic system for, as he insisted, important forms of capitalism are older than the Reformation and Calvinist inhabitants of the Sahara do not automatically become factory-owners. He was really only interested in the analysis of one component of the capitalist spirit, a component which had a particular affinity to the capitalist system: the ethos of a bourgeois conduct of life or the rational conduct of life on the basis of the idea of the calling which gave a specific direction to the methodical conduct of life.

While during the Middle Ages the entrepreneur felt at best tolerated by God, so that an inner tie between economic activity and the ethical centre of the personality was lacking- with the consequence that money earned by usurious profiteering was often returned at the end of one's life -, Weber found among the Protestants the entrepreneur with an unbroken good conscience, the professional who felt at one with his actions. The specific characteristics of a conduct of life which was completely impregnated by the spirit of capitalism, i.e., impersonalism, a calculating spirit, rational consequence, a specialized narrowing of the outlook, a seriousness of outlook deprived of all naïveté, had found here their ethical self-justification. When elsewhere or at other times these religious motivations of the Protestants were lacking in the life-style of entrepreneurs, their capitalist activities were not normally the expression of a style of life based on the unity of the personality - and it would be an error to believe that this fact would be without consequence for the position of capitalism within the whole culture, its cultural effects and its destiny (AC: 102).

Thus, the primary purpose of Weber's anti-critiques is the differentiation between the capitalist spirit and the capitalist system ${ }^{15}$ and, further,

15 The difference between «spirit» and «system» in Weber's writings can be interpreted in such a way that the spirit motivates people from the inside and produces an inner habitus while the system is the net of actions which people complete because of exterior circumstances. 
the accentuation of a high elective affinity ${ }^{16}$ of one component of the capitalist spirit, created by Protestantism, with the modern capitalist system. At the same time, though, Weber mentions - just as in his essay on the Protestant sects - that besides the religiously induced motivations for economic action there were also those motivations which were supported by the religious and social institutions created by the sects. This becomes particularly apparent in the central sacrament of the Eucharist. For, on the one hand, every Protestant asked himself whether he was qualified to participate in the Eucharist - and this question was not answerable by a precise accounting of particular sins and merits, but only by an evaluation of the ethical conduct of life as a whole, the total personality -, but, on the other hand, he was under the constant control of his equals, the members of his congregation who, as the guarantors of congregational discipline, had the responsibility to see to it that the Eucharist would not be desecrated by the unworthy who bore the visible signs of rejection, and thus to maintain the ekklesia pura. This congregational discipline had a considerable influence on the conduct of life, particularly if one adds to it the ethical training which was given to the members and also the necessity for businessmen to legitimize themselves and to prove their ethical standards by their membership in a sect (AC: 110).

\section{The 1920 Version of the «Protestant Ethic»}

\section{Basic Literature:}

Max Weber The Protestant Ethic and the Spirit of Capitalism (translated by T. Parsons with an introduction by A. Giddens) London: Routledge 1992

Max Weber Gesammelte Aufsätze zur Religionssoziologie vol. 1 Tübingen Mohr 1920

16 The so-called «Weber thesis» has sometimes been interpreted as referring to a causal hypothesis and at other times to an «adequate relationship» between the capitalist structure and the capitalist spirit. Weber himself, particularly in AC: 95, referred to an adequate relationship, but he did not indicate whether the relationship was «meaningfully adequate» or «causally adequate» - whether the meaning relationship of the parts should be considered as typical or whether in our experience there is a chance that a sequence of events always happens in a similar way (as formulated in the chapter «Basic Sociological Terms» in ES: 11). Instead of adequacy, Weber sometimes uses the term «elective affinity». 
The essays on the Protestant Ethic and on the economic ethics of world religions which had originally appeared in the Archiv für Sozialwissenschaft und Sozialpolitik were republished by Weber in 1920/21 with some changes and additions as parts of the Collected Essays in the Sociology of Religion. The essay on the Protestant Ethic which appeared in the first volume of the Collected Essays in 1920, and on which most English translations are based, was not a verbatim reproduction of the original essay of 1904/5. This was already visible in the title, for the quotation marks which in the original version were set around the word «spirit» were omitted in 1920. Weber insisted, however, in a footnote on the first page that he had not changed, reinterpreted or softened a single assertion and that he had not added any divergent assertions.

In part the newly added passages are repetitions or continuations of Weber's Replies to his Critics (AC), sometimes without naming the addressee. Repeatedly and with much insistance Weber tried to clarify that there exist different kinds of capitalism. ${ }^{17}$ Capitalistic phenomena in the sense of a class concept ${ }^{18}$ can be found everywhere in the world and at all times, in China, India, Babylon and Antiquity. But this was the capitalism of adventureres, usurers, war suppliers, tax farmers and financial magnates and had no relationship whatever with the specifically modern capitalism and its particular ethos.

Secondly, it mattered to the Weber of 1920 that his readers understand the difference between simple ethical teachings and concepts and the psychological motives created by religions. ${ }^{19}$ It was important to him to show that Protestantism put psychological premia on diligent work. In a four pages long footnote (PE: 140, fn. 12) Weber analyzed the worldly wisdom

17 In many places of the final version of the $P E$ Weber inserted such comments, e.g. PE:135: fn.13; PE: 17; PE: 22; PE: 148: fn. 22 \& 23; PE: 229, fn. 7; PE: 122.

18 As mentioned earlier, Weber distinguished two kinds of concepts: one kind is a class concept which describes in conceptual purity that which is everywhere the same (capitalism in general), the other is of an individual character, an ideal type, and underscores those features which are unique (e.g. modern Western capitalism).

19 These allusions to the fact that Weber was interested in religiously created psychological premia and not in ethics or wisdom literature can for instance be found in PE: 141, fn. 12 (a five pages long footnote) or in PE: 236, fn. 31. But even in the original version of 1905 Weber had said: «What a religion has sought after as an ideal and what the actual result of its influence on the lives of its adherents has been, must be sharply distinguished» PE: 137, fn. 24 or PE1: 47, fn. 17. 
teachings of the versatile genius of the Renaissance, Leon Battista Alberti, and he attempted to show that this kind of literary theory, quite unlike any religious ethic, did not have at its disposition any psychological sanctions of a non-economic character and did not produce a life-transforming power from within. In the case of Alberti, he said, we simply find a paradigma of immanent economic rationalism. Further on Weber mentioned some theologians of the fourteenth century who presented the profit of the merchant as a reward for his industria and therefore ethically justified. But the most important thing was lacking, according to him: the proof of one's own salvation in a calling and thus the psychological sanctions which Protestantism set on diligent work. In the examples discussed by Weber there was only ethical teaching or concessions to practical necessity and not religious premia.

The distinction between ethical teachings and psychological motivation was also used by Weber in regard to new examples which he had unearthed while examining the other world religions. Thus he noted that Indian religious teaching connected economic traditionalism with the chances of a favourable rebirth (PE: 236, fn. 31), an excellent example by which to show the difference between mere ethical theories and psychological motives. And with regard to ancient Judaism and its ethical dualism which permitted a behaviour towards strangers which was not permitted towards brothers, Weber stressed that success in the area of simply permitted behaviour (an ethical adiaphoron) cannot become a sign of religious proof and a motive for a methodical conduct of life, for the psychological motivations led to a different result (PE: 244).

In the already mentioned footnote on Alberti (PE: 144/5) Weber applied his distinction between ethical teachings and psychological motivations to the whole of his essays on the economic ethics of world religions ${ }^{20}$ : "What ... a religiously oriented rationalization of conduct looks like may be seen, outside of the Puritans of all denominations, in the cases of the Jainas, the Jews, certain ascetic sects of the Middle Ages ... the Skoptsy and Stundists in Russia and numerous monastic orders. The essential point is that an ethic based on religion places certain psychological sanctions (not of an economic character) on the maintenance of the attitude pre-

20 While Weber did emphasize that it is not enough to study religious doctrines without considering their psychological effects in a given context, it is nevertheless true that in large parts of his essays on world religions he limited himself to the interpretation of classical texts. 
scribed by it, sanctions which merely worldly wisdom like that of Alberti does not have at its disposal. Only in so far as these sanctions work, which is often very different from the doctrine of the theologians, does such an ethic gain an influence on the conduct of life and also within the economy. This was the point of the essay on the Protestant Ethic»».

The aforementioned additions in the version of 1920 may be considered as clarifications of what Weber had written in 1904/5 or as comparisons and examples drawn from the essays on the economic ethics of world religions. But one also finds in the PE version of 1920 completely new insights which would have been impossible without the knowledge of the results of the studies of the world religions. There is for instance Weber's allusion to the great historical process of the disenchantment (Entzauberung) of the world which had begun with the old Hebrew prophets and, in conjunction with hellenic scientific thought, had repudiated all magical means of salvation and came to its logical conclusion in Protestantism (PE: 61). The concept of religious disenchantment did not appear in the original edition of the $P E$, as it presupposes the essay on ancient Judaism, but can be found several times in $1920 .^{21}$

Furthermore, Weber turned in 1920 to the concept of theodicy: «The complete elimination of the theodicy problem and of all those questions about the meaning of the world and of life which had tortured others, was as self-evident to the Puritan as, for quite different reasons, to the Jew» (PE: 65). Indeed, in his study of ancient Judaism he had already pointed to the economy of psychic ressources which manifests itself if all rumination about the meaning of the cosmos is precluded.

And, finally, Weber mentioned for the first time the immense tension which it was the unavoidable destiny of the Calvinist to endure as no priest and no sacrament could provide him with certainty with regard to salvation (PE: 71). This tension in which the Puritan, as opposed to the Confucian, found himself played an important rôle in the last part (Result) of the essay on Confucianism and Taoism.

21 The English translation by T. Parsons does not use the term disenchantment at all, but rather uses «elimination of magic from the world» (e.g. PE: 61, as translated from GARS I: 94) or «rationalization of the world» (PE: 71, as translated from GARS I: 114). Weber's terminological precision is lost in the process. 


\title{
CHAPTER III THE WORLD RELIGIONS AND THEIR ETHICS
}

\author{
1. Max Weber's Introduction
}

\section{Basic Literature}

Max Weber «The Social Psychology of World Religions» in: Gerth \& Mills (transl.\& ed.) From Max Weber. Essays in Sociology Oxford University Press 1958, pp. 267-301

Max Weber «Einleitung» in Gesammelte Aufsätze zur Religionssoziologie I, Tübingen: Mohr (Siebeck) 1920, pp. 237-275

The «Introduction» is fundamental for the understanding of Weber's «Economic Ethics of World Religions»; it provides some basic interrelated concepts and a method of comparing religions in their socio-economic context, as socially relevant as well as socially conditioned. ${ }^{22}$ Weber remarks at the outset that by «world religions» he understands those systems of life-regulation which have had a large multitude of adherents, such as the Confucian, the Hindu, the Buddhist and the Christian religious ethic, and also ancient Judaism because of its historic significance for the modern economic ethic of the Occident. Later in this text Weber discusses salvation religions (which promise the release from suffering), and it will be-

22 H. Kippenberg (1995) has suggested that in the newly developing discipline of the history of religions Weber found ideas which, in contrast to the ideas of the Enlightenment, saw religion as an independent phenomenon, having its own value and right to exist and the possibility to follow «the laws of its own» (ES: 341), not those of the economy. This allowed him to suggest that a historic process in the religious development of the Occident led to the foundation of modern rational culture as well as to different kinds of rationalization in other cultures. From scholars in the history of religions (Max Müller, C.P. Tiele, Troeltsch) Weber may also have taken many of the concepts which he used in his essays on the world religions, for instance the distinction between nature religions, cvilizational religions, and salvation religions, the distinction between a personal and an impersonal god, the idea that there are levels and directions in religious development, and the suggestion that the experience of the irrationality of the world is the driving force of salvational conceptions and of theodicies (FMW: 123). 
come possible to say that Confucianism and Islam are world religions or civilizational religions, whereas Hinduism, Buddhism and Christianity are also salvation religions. All world religions, however, have this in common, that they have broken out of magical world views and developed a conduct of life, oriented by a coherent and systematized set of values, that their adherents follow duties and ritual and do not live with tabu-like norms or magical coercion, or that they distinguish between what is and what ought to be. ${ }^{23}$

Weber mentions two kinds of religious ethics: on the one hand, there are ritualistic and legalistic ethics which lead to stereotypes of ethical behaviour, and on the other hand, there is the ethic of conviction which systematizes the religious requirements and leads to a distinction between morals and law. It results in a coherent conduct of life, the constancy of one's inner relations to ultimate values and the formation of a personality.

When Weber talks of the economic ethic of a religion, he does not refer to the ethical theories of theological compendia, but he points to the practical motivations for action, founded in the psychological and pragmatic contexts of religions. Economic ethics are not simply «functions» of a form of economic organization; rather it may be possible to say that among the determinants of an economic ethic is the religious influence on the conduct of life, combined, however, with the constellations of interests and the respective personality formation. It is true, moreover, that externally similar forms of economic organization may be compatible with very different economic ethics.

23 A more extensive distinction between magic and religion is provided by Weber in Economy and Society. He stresses that the magical world view consists of a complex of heterogeneous oracles, prescriptions and prohibitions which cannot be unified or systematized (ES: 437). «Magical ethics» can be seen as benefit calculating coercion of a god or spirit so that the distinction between the two oppositions useful/harmful and good/bad is blurred. The religious world view, on the other hand, particularly the world view of the so-called axial religions characterized by Karl Jaspers (1949), is dualistic; it assumes that behind the real things and events there is something else, of which real events are only symptoms or symbols, and it presupposes the concept of a radically other world, meaningfully ordered, coherent and systematized (ES: 451), and a tension between this world and that other world. It also includes a system of norms, so that not coercive magic, but a conduct of life according to these norms can influence the fate of humans. But, even when the religious world view turns away from magic, it is rare that magic is completely eliminated. 
In the following essays, Weber writes, it will be attempted to uncover the conduct of life of the social strata which have most strongly influenced the practical ethics of their respective religions: Confucianism was the status ethic of secular-rational prebendaries, the mandarins, earlier Hinduism was borne by the hereditary caste of the Brahmins, Buddhism was propagated by world-renouncing monks, post-Exile Judaism was the religion of a pariah-people and Christianity that of urban artisans, citizens of the quite singular occidental city. However, in spite of these social influences, religious ethics received their stamp primarily from religious sources. Even Nietzsche's theory of resentment of the disadvantaged and of the «slave revolt in morals» does not change this fact although his references to suffering have, according to Weber, some justification.

Suffering was originally considered to be a symptom of the wrath of a god, for the fortunate is seldom satisfied with the fact of being fortunate: he also wants to know that he has a right to his good fortune. Thus, religion was often used to legitimate the good fortune of the propertied, the mighty, the victorious or the healthy. But before, on the other hand, the religious glorification of suffering could arise, it was necessary to realize that certain forms of abstinence and of chastisement could awaken or further the charisma of ecstatic or visionary states that were considered as holy. It was assumed that certain kinds of suffering provoked through chastisement are avenues to the attainment of superhuman powers. To this must be added the development of cults of salvation which took a new position in the face of individual suffering. While the primeval cults of political associations left all individual interests out of consideration, there developed within or besides them myths of a saviour (and hence a rational view of the world) who promised salvation from suffering for individuals qua individuals, particularly among the less favoured strata. In many cases, some kind of theodicy of suffering has originated from the hope for salvation, and such rational theodicies provided individual suffering with a positive valuation.

The need for an ethical interpretation of the meaning of suffering and of the distribution of good and bad fortunes among humans furthered a growing rationalization of the conceptions of the world; the experience of the meaninglessness of the world led the religious development on the path of rationalization or of an inner logic which systematized the explanations. Among the many explanations of suffering and injustice which one encounters, only three gave rationally satisfactory answers: the Indian doctrine of karma, Zoroastrian dualism and the predestination decree of the 
protestant deus absconditus (the God whose reasons for his decisions are inaccessible and thus hidden to the human mind).

The theodicies of suffering may indeed sometimes be coloured by resentment; but the distrust of wealth and power which as a rule exists in genuine religions of salvation, must be explained by the fact that those strata which are satiated and favoured in this world, have generally only a small urge to be saved and are less «devout». Moreover, the development of a rational economic ethic in the lower strata has the following reason: while the sense of dignity of the higher strata tends to feed on their actual or assumed being, the sense of dignity of the lower strata is often nourished by the belief that they have a special mission or that they follow an ethical imperative. The source of the power of ethical prophecies among the socially disadvantaged strata lies in this fact.

Salvational goods, even when they are understood as "otherworldly», have a this-worldly character. The Puritan certitudo salutis (feeling certain of one's salvation), the Indian's bhakti (fervent love in the possession of God), the radenie (joyful ecstasy) of the Khlysts in Russia were sought because of their psychic extraordinariness. Even if the rationalized religions imputed a metaphysical meaning to these goals, the salvational good was for the devout a psychological state in the here and now. One can distinguish between religious and profane states only by referring to the extraordinary character of the religious states.

The kinds of salvational goods that are sought after by religions have varied according to the social strata which were foremost in adopting them. The business classes (merchants and artisans) have often been the exponents of practical rationalism while a more theoretical rationalism has been advanced by intellectuals. It has always been the work of intellectuals and priests to sublimate orgy into sacrament and to transform unformed and irrational religious beliefs into a rational system of thought concerning salvation. It depended on these rational systems of religious thought or world views, be they Confucian, Indian, Islamic or Calvinist, from what and for what one wished to be saved, what in the actual world appeared to be particularly meaningless and to what kind of salvation one aspired. Even if material or ideal interests determine men's conduct, these 
rationally constructed world images have, like switchmen, determined the tracks along which human action has been pushed (FMW: 280). ${ }^{24}$

Hierocracies have sought to monopolize the administration of religious goods of salvation in the form of sacramental or institutional grace; political bureaucracies have generally been suspicious of individual pursuits of salvation and have insisted on social obligations and on the ritualistic character of religion; peasants have generally been inclined towards magic.

Bourgeois strata are the most ambiguous with regard to the religious options they have chosen, yet elective affinities or mutual attractions between these strata and certain special types of religion stand out. Because of the nature of their way of life which is detached from economic bonds to nature and because their whole existence is based upon technological and economic calculations, there existed the possibility that a tendency towards an ethical and rational conduct of life might develop, particularly if a prophecy provided a religious basis for it.

Weber distinguishes, on the one hand, exemplary prophecy which points out the ideal of a contemplative life-style, of being a vessel of the divine, by exemplary living ${ }^{25}$ and, on the other hand, emissary prophecy which addresses demands of an ethical and ascetic character to the world in the name of a god and where the individual regards himself as an instrument of this god. The active asceticism propagated by emissary prophecy has often been the preferred religious attitude of bourgeois strata - in opposition to the contemplative mysticism of exemplary prophecy which was preferred by intellectuals. Moreover, emissary prophecy and asceticism have had a profound elective affinity to the conception of a supramundane personal god of creation, in contrast to the impersonal and immanent supreme being of exemplary prophecy. The first conception has dominated the Near-Eastern regions and the Occident, the second one has dominated Indian and Chinese religiosity. ${ }^{26}$

24 Weber thought that interests are blind, and no continuous rationalization can proceed from them, as adventurer or booty capitalism have often shown. Images of the world, articulated by ideas, must discipline and lead the interests in the sense of a methodical and in this sense rational conduct of life. All societies have faced this situation, but they have found different solutions.

25 Another aspect of exemplary prophecy, according to Weber, is the Socratic dialogue in which the opponent is led ad absurdum by rational arguments (RI: 225).

26 Peter Berger has developed the contrast between a transcendent god and asceticism on the one hand and an immanent god and mysticism on the other hand in 
The rational elements of a religion, its «doctrine», e.g. the Indian doctrine of karma or the Calvinist concept of predestination, have their inner logic (Eigengesetzlichkeit), and the rational pragmatism of salvation which flows from them, for instance from the nature of the conception of God (transcendent or immanent), has often had far-reaching results for the fashioning of a practical conduct of life. The mystic Meister Eckhart, for instance, could not realize the pantheist experience of the mystic without sacrificing some of the decisive elements of the Occidental belief in a transcendent God, and the Muslim mystic al-Hallaj was executed in Baghdad in 922 for his formula «I am truth», implying identification with God.

It may therefore be said that, on the one hand, the nature of the desired salvational goods has been strongly influenced by the external interests and the conduct of life of the ruling strata but that, on the other hand, the direction of the conduct of life, in so far as it was methodically rationalized, was profoundly determined by religious values of the doctrinal system and its inner logic.

In this context it is important to point to the fact that men have unequal religious qualifications: heroic or virtuoso religiosity is opposed to mass religiosity, the religiosity of those who are religiously «unmusical». The hierocratic and official authority of a church which organizes the masses, fights principally against all virtuoso-religion and its autonomous development: the religiosity of the Ulema stood against that of the Dervishes in Islam, the early Christian bishops against the pneumatics, the Russian state church against the sects, the Confucian officials against Buddhist and Taoist pursuits of salvation. Religious virtuosi have often seen themselves compelled to adjust to everyday religiosity in order to maintain ideal or material mass-patronage. The nature of their concessions has been of primary significance for the way in which religion has influenced everyday life. In most parts of the Orient, the religious virtuosi allowed the masses to remain entangled in magical traditions while in the Occident they have undertaken to ethically rationalize the life of the masses.

Clearly also the peculiar nature of the virtuoso-religiosity has been of decisive importance: wherever it was of a contemplative or orgiastic-ecstatic character, there has been no bridge between it and everyday life, because no psychological motives for innerworldly economic action could

more detail. He calls it the opposition between Jerusalem and Benares. P. Berger The Heretical Imperative London: Collins 1980 
be derived from it. Contemplative and ecstatic religions are rather hostile to economic life, and where they are dominant, a deep abyss separates the way of life of the «laymen» from that of the virtuosi. While the virtuoso might be a directeur de l'âme (spiritual guide) of the «laymen» - as the Buddhist bhikku or the Russian starets - the influence would be in merely ritualist and conventional particulars, for action in this world remained in principle religiously insignificant.

Things were very different where the religious virtuosi attempted to mould the world according to the will of a god. In this case, the salvational goods were not of a contemplative character, like a unio mystica, nor were the means of salvation of a magical or sacramental kind, for these means tend to devalue action in this world as insignificant and they do not link salvation to practical and everyday events. Thus, two things were achieved: the disenchantment of the world and the turning away of the path of salvation from a contemplative «flight from the world» towards an active fashioning of the world. Apart form small rationalist sects which are found all over the world, this has happened mainly in Occidental Protestantism. Why did this happen?

Partly it was the influence of the stratum that was decisive for this religion, i.e., the bourgeois stratum, partly, however, it was the conception of a supra-mundane God and the specificity of the method of salvation. Where the religious virtuoso saw himself as an instrument of God, under the necessity to prove himself or his ethical qualifications before God, he might reject the world as it is (in the sense that he despised the values of dignity or beauty or worldly power), but he would not flee from the world, as in the case of contemplative mysticism. He remained oriented towards the world in a more specific and thoroughgoing sense than did the naive «affirmation of the world» of unbroken humanity in Antiquity or in layCatholicism. Thus, the Occidental sects of religious virtuosi have fermented the methodical inworldly rationalization of conduct, including economic conduct. Between the polar opposites of world-fleeing contemplation and world-dominating asceticism, however, one finds the most varied transitions and combinations.

On the whole it can be said that, with regard to salvation religions Weber uses in the «Introduction» four criteria for their characterization. 1. Their concept of God (transcendent or immanent), 2. their method of salvation (world fleeing contemplation of world dominating asceticism), 3 . their salvational goods (knowledge of the world or knowledge of personal destiny) and 4. the carrier strata of these religions (intellectuals/monks or 
bourgeois strata). The characterization of the other world religions is more pale: Confucianism, based on a stratum of secular prebendaries and with the concept of an impersonal eternal order, pursues «cultural» qualifications or the ideal of a «cultivated» man, and Islam, a warrior religion with a transcendent God.

The «Introduction» concludes with some methodological comments. The world religions which are to be discussed here, are not simply types which represent stages of development. Neither a systematic typology of religion nor a purely historical work is intended. The essays are typological in the sense that they consider what is typically important in connection with the great contrasts of the economic mentalities of the world; the world religions are presented in greater logical consistency and unity than has ever been the case in their actual development in order to underscore the differences of those features which have been decisive for the practical way of life. These features interest Weber primarily from a definite point of view, namely their relationship to economic rationalism, i.e., that type of rationalism which, since the sixteenth century, has come to dominate the Occident.

It must be underscored here that «rationalism» may mean very different things. The systematic rationalization of a conception of the world by means of abstract concepts is very different from the methodical-rational attainment of a given practical end by means of precise calculation and adequate means. And even the rationalization of the conduct of life, which is of particular interest here, can assume enormously different forms: Confucianism is «rational» in the sense of the absence of all metaphysics and almost all residues of religious anchorage; the artistic ideal of the Renaissance was «rational» in the sense of a belief in a valid canon; the Indian practice of yoga and certain aspects of later Buddhism are «rational» in the sense of methodicalness; finally, all practical ethics which are systematically oriented to fixed goals of salvation, are «rational» in the sense of methodical conduct and also in the sense that they distinguish between valid norms and the empirically given reality. It is this last type of rationalization process which will play a major role in the following presentations.

The ethics of individual religions are presented more systematically than they have ever been in their actual development. The presentations do not claim to offer a well-rounded picture of world religions in the same sense as monographs do. 
Finally, some terminological peculiarities which recur in the following presentations and which concern the external conditions under which economic ethics develop, should be clarified. All ruling authority, political or religious, can be considered as a variation of three ideal types constructed on the basis of the legitimacy which the ruling authority claims to have.

1. «Charisma» should be understood to refer to an extraordinary quality of a person, be it actual or only presumed. The magician, the prophet, the demagogue may have it. Charismatic rule does not follow general norms and in this sense it is irrational. It is revolutionary as it does not feel bound to the existing order.

2. «Traditionalism» is the belief in the everyday routine as an inviolable norm. Its most important type is patriarchalism, the authority of the father, the senior of the household, the lord of servants and officials and, as a variety of patriarchalism, the patrimonial lord, the sovereign over his subjects. Central norms are considered sacred, but there is also an area of arbitrariness where the lord makes decisions in terms of personal considerations.

Throughout history only charismatic leaders were able to integrate new laws into the sacred tradition and custom, but, as charismatic periods never lasted very long, the charismatic leaders and the staff supporting them (disciples, apostles, military followers) soon succumbed to routinization. The followers soon depended on their leader for maintenance through income in kind, usufruct of land, appointments, or more generally prebends, and felt entitled to them. In this way the leader's prerogatives became patrimonial in nature.

But often there developed a struggle between the patrimonial leader and the erstwhile followers who as a status group felt to have a right to their prebends and privileges. If the struggle was decided in favour of the ruler so that he could attach to himself a staff of officials who depended solely on him, he acquired administrative means and finances of his own and gradually expropriated the privilege holding groups. The new stratum of officials was often composed of literate clerics, in the Middle East of slaves and clients, of secularized literati in China and of jurists in the modern Occident. It must be noted that the triumph of princely power has often resulted in the introduction of a rational administration which, however, could take two forms: substantive and formal rationalization. The former is utilitarian, the patrimonial leader bestows social blessings upon his subjects; the latter appears when trained jurists carry out a rule of general laws applying to all citizens. 
The «triumph of formalist juristic rationalism» (FMW: 299) leads to the third category besides charismatic and traditional authority: legal authority.

3. Legal authority is based on rationally established rules (enactments, agreements), in turn resting upon a rationally enacted constitution. Officials hold their power as trustees of an impersonal Anstalt (compulsory institution $)^{27}$ and this is not only true in regard to the state but also in regard to the hierocratic association, the church. In fact, legal authority based on formal rationalization gave birth to the modern occidental «state» as well as to the Church as an institution. In its purest form it is bureaucratic rule and implies an impersonal bond of the office holder to the duty of office, the obligation to work sine ira et studio (neither with anger nor with affection) according to rationally established norms and regulations.

Weber did not claim that all empirical structures of domination must correspond to one of these ideal types. On the contrary, most are in a state of transition between several of these types so that he often felt compelled to form new expressions like «patrimonial bureaucracy» which point to its hybrid status. But Weber felt that his concepts are useful for orientation.

\section{Confucianism and Taoism}

\section{Basic Literature}

Max Weber The Religion of China New York / London: MacMillan 1951

Max Weber Gesammelte Aufsätze zur Religionssoziologie I Tübingen: Mohr (Siebeck) 1920 pp. $276-536$

Wolfgang Schluchter Rationalism, Religion and Domination (Chapter III, Confucianism and Taoism), University of California Press 1989

Weber begins with an historical analysis of the Chinese monetary system, the fluctuating availability of monetary metal and the difficulties with paper money, and he then immediately points out that, although a strong in-

27 Weber defined Anstalt as an organization which imposes, within a specified sphere of operations, its order on all action conforming with certain criteria - as opposed to an organization which claims authority only over voluntary members (ES: 52). For a slightly different explanation of Weber's use of this legal term, vide footnote 85 in the section on Occidental Christianity. 
crease of wealth in precious metals can be detected since the 16th century, this did not stimulate a capitalist development. Nor was capitalist development stimulated when, after the pacification of the empire under the Qing and after the edict of 1713, the controls of occupational choice and the barriers to free mobility were eliminated and an astounding population increase occurred (from 50-60 million people in the middle of the 17th century to $350-400$ million at the end of the 19th century). While the intensity of Chinese acquisitiveness at all times cannot be doubted, and while it is certain that entrepreneurial communities, small-capitalist in nature and organized as communal workshops (ergasteria), did exist, large private capitalist factories can scarcely be traced in Chinese history. It is Weber's central problem, then, to explain why, despite apparently many favourable conditions, not the slightest beginnings of capitalist development did appear. He finds the reasons in the structure of the Chinese state and in the interests which supported it, on the one hand, and, on the other hand, in the intellectual and religious circumstances.

\section{The Patrimonial Domination}

Weber's distinction between the time of the Warring States and the united empire is fundamental for his understanding of China. The competition of the Warring States (before 221 A.D.) for political power caused their leaders to initiate rational economic policies as well as a rational administration and organization of the army; but the elimination of political competition after the creation of the world empire put an end to the rationalization in administration and in economic policies. Moreover, during the period when the Warring Kingdoms competed for political power, there existed a capitalism of moneylenders and purveyors, and under the Han dynasty, there are said to have lived multimillionaires in mining and trade, but the political unification in the world empire, like the unified orbis terrarum of Imperial Rome, resulted in a regression of this capitalism. Finally, the unified empire eliminated the competition of the intellectual doctrines and imposed a unified orthodox doctrine: Confucianism. It is noteworthy that Weber's evaluation of the smothering effects of the unified Chinese patri- 
monial empire is closely related to his understanding of the development in the Roman empire. ${ }^{28}$

This unified empire - characterized mainly by its bureaucracy - prevented, according to Weber, all industrial capitalist development. It is a patrimonial bureaucracy we are dealing with here, to be distinguished from modern bureaucracy. While modern bureaucracy means the purposively rational organization with a staff of specialized officials trained in the law who apply the law and the decrees without respect of persons, patrimonial-bureaucratic organization does not distinguish between office and person, between legal procedure and administrative procedure, between formal law and material justice. In China, incidentally, the relationship of the official to the patrimonial and caesaro-papistic emperor was one of personal subjection. ${ }^{29}$

28 Weber's «Agrarverhältnisse im Altertum» of 1909 in Handwörterbuch der Staatswissenschaften (Agrarian Sociology of Ancient Civilizations - SAC) is important for the understanding of his essay on China, for the study of the social conditions of the Roman empire first called his attention to the smothering effects of a large bureaucracy for capitalism. Certainly, in ancient Rome there was no modern capitalism, but only tax farming, slave labour and political capitalism, but while republican Rome had favoured these kinds of capitalism, the increasing bureaucracy during the Monarchy obstructed all sources of profit, according to him.

29 G. Hamilton in «Patriarchalism in Imperial China and Western Europe» (Theory and Society vol 13, no.3 (1984), p. 393 sqq.) has argued that Weber generated some of his concepts, such as patrimonialism and charisma, from an analysis of Western history. For instance, patriarchalism is based on the patria potestas in Roman law, the fathers's authority over the household which demands piety toward tradition and to the master (ES: 1008) who can exercise personal discretion. State justice stopped at the threshold of the household. Patrimonialism, according to Weber, is a variety of patriarchalism and refers to the ruler's authority over the state. In China, on the other hand, there is xiao, filial piety or rather faithfulness to the duties of one's position in life: not only the duties toward one's father but towards all persons to whom one is related. It implies a denial of individual desires and, as Hamilton writes, a negation of personal magic which Weber calls charisma. Not personal loyalty towards one's father or relatives or to the emperor is required, but loyalty to one's rôle. Patria potestas and xiao cannot be equated as the first is related to power and the second to an order created by a relationship of roles, and therefore the concepts of patriarchalism and patrimonialism are inadequate for the analysis of China, according to Hamilton, as they are not useful in developing a genuine understanding of Chinese history (ibid. 419).

Although this seems to be a serious challenge to Weber's use of terminology, it must nevertheless not be forgotten that a «genuine» or «true» understanding of China or of anything else was not in Weber's intentions. In fact, he considered this 
Appointment to office in the bureaucracy was generally reserved to the literati-class whose members had qualified themselves in the official examinations. Such positions were treated as non-hereditary prebends, offered on the basis of individual qualifications.

The officialdom as a whole had good reasons for the traditionalism which characterized it. While it is true that their prebends were not individually appropriated, they were, nevertheless, appropriated by the whole stratum of removable literati. Therefore, the literati opposed collectively all interventions which conflicted with their interests. They were able to prevent the refeudalisation of the administration by the nobility as well as the introduction of oriental sultanism by the imperial eunuchs; they were in a position to thwart the creation of an expert officialdom in the $11^{\text {th }}$ century because it would have threatened their prebendary interests.

The administration of this patrimonial bureaucracy was not intensive at all so that in the villages the power of the sibs was able to blossom: the sibs supported the self-sufficiency of the households, thereby reducing the necessity of a market. The professional organizations, merchant and craft guilds, were in fact autonomous, but the cities had less guarantees of selfgovernment than the villages, and they were therefore unable to create the legal foundations for capitalist «enterprise» which can already be found in the commercial law of the Italian cities of the Renaissance. The character of the patrimonial form of state which upheld a sacred tradition alongside a realm of prerogative and favouritism impeded the development of industrial capitalism, for it lacked a rational and calculable administration and law enforcement.

\section{The Spirit of Confucianism}

In this patrimonial structure there lived the «spirit» of Confucianism. It was acquired during the course of the literary-Confucian education and during the preparation for the official examinations and expressed in the conduct of life of the officials and the literati. In fact, patrimonialism was

impossible. His comparative sociology produces questions from a specific perspective, pointing the investigation in a particular direction within a thought-out reseach program. The cultural sciences consist, according to him, in a constant process of reshaping our concepts by means of which we seek to grasp reality (CMW: 133/4). 
the form of state fundamental to the Confucian spirit. The spirit of a lifelong «pennalism» was instilled by unceasing study of the old classics combined with grace and dignity in the sense of a ceremonially ordered court-style, and the examinations leading to official positions tested whether the candidates possessed the ways of thought suitable to a cultured man. This education towards the ideal of a «cultured man» was in accordance with the material and ideal interests of a literary officialdom.

The idea of (religious) salvation was completely absent from the Confucian «spirit». Abhorring orgiastic and any kind of ecstatic behaviour, the Confucian literatus desired only to be saved from the undignified barbarism of social rudeness to a virtuous life. His god was an unpersonal power, no supra-mundane lord creator made ethical demands on him; magic, although he did not doubt its existence, appeared to him without significance for salvation, but he did not try to systematically transform the magical popular cults.

For this Confucian «spirit» economic income represented the «little path»; it viewed specialized professional training as a conditioning in philistinism for, as it was said, «a cultured man is not a tool», nor is he a means for a specified useful purpose. Thus, specialized training in any field, be it law or economics for administrative purposes, as in modern Western societies, was not the desired outcome of the Chinese education process. Rather, the examinations tested whether or not the candidate's mind was thoroughly steeped in literature and whether or not he possessed the ways of thought suitable to a cultured man (RC: 121). One could not achieve anything in the world, not even in the most influential position, without the virtue derived from this kind of education - nor, it is true, without influential position. And therefore the Confucian literatus coveted such a position, not profit.

\section{Heterodoxies}

Weber then asks whether perhaps the non-classical popular religion, particularly Taoism, a heterodoxy which was not rejected by Confucianists ${ }^{30}$, has been the source of a differently oriented methodical way of life. Again

30 As opposed to sects which are in an inner conflict with the socio-political system, heterodoxies are not directly connected with it because of exterior circumstances, but do not reject it in principle. Heterodoxies can sometimes turn into congrega- 
he uses a comparison with classical antiquity. While in ancient Greece the cult of the Homeric gods was recognized as an official institution and the teaching of the philosophers an optional private matter, quite the opposite relationship between popular cult and philosophical teaching was found in China: here the Confucian teachings had been canonized by a caesaro-papistic regime while the popular cults were suspiciously tolerated and viewed as a private affair. On the other hand, there existed officially unauthorized cults, often of a soteriological kind, in the Roman Empire; but while here the development led to an alliance between one of these soteriological communities, i.e. Christendom, and the state, Chinese history followed a different course.

While it seemed for a time as if Buddhism in China might play a role similar to Christianity's role in the West, the interests of the Confucian bureaucracy prevented such a development. The Chinese adoption of Buddhism, the effect which it had on the conduct of life and the kind of individualism which was introduced by it, will be touched upon in the section on Hinduism and Buddhism.

Among the popular religions Weber discusses mainly Taoist mysticism which, although it minimized action, did not lead to the conclusion of the absolute rejection of the world, for it did not reject in principle the ideal of the educated literatus and gentleman. It is a paradox, a lack of inner consequence in Lao-tse's system, ${ }^{31}$ that he does not completely reject innerworldly action. As, moreover, a supra-mundane personal god was lacking, the possibility to develop an asceticist ethic which contrasts God and creature was precluded. All religiously motivated, active antagonism to the world was lacking, and lacking was also, finally, a vocational ethic which could only have sprung from an asceticist ethic of laymen, originating from a tension between God's will and the conditions of the world. Taoism did not have its own «ethos": magic, not conduct of life, was decisive for man's fate.

tional religion as in the case of Judaism, early Buddhist monachism or Russian Old Believers.

31 A lack of inner consequence or an inner contradiction in religious systems (not only in Taoism, but also, for instance, in Jainism) has generally led, according to Weber, to a reduction of intensity of innerworldly or otherworldly activity because clear tracks for the conduct of life (as in Puritanism or Hinduism) in the pursuit of interests were not provided. 
The toleration of magic within the Chinese conception of the world in general and its positive cultivation by Taoism was particularly stressed by Weber. Astrology, pharmacology, geomancy, etc. transformed the world into a magic garden the fruits of which were enjoyed by the masses of the people. There was no path leading from Taoism to a rational method of life, be it inner - or other worldly, but Taoist magic necessarily became one of the most serious obstacles to such a development.

\section{Conclusion}

The Confucian bureaucracy largely succeeded in confining sect formation to occasional flare-ups, for the specific aspect of sectarianism that the value and worth of the personality are guaranteed and legitimated not by blood ties or publicly authorized degree, but by being a member of and by proving oneself in a circle of specifically qualified associates, was particularly odious to the caesaro-papistic state. The formation of religious communities for the laymen - a sociologically decisive fact - was lacking, and for this reason magic has never been displaced by a great prophecy of salvation.

It is of decisive importance that the patrimonial structure of state, and the Confucian spirit which lived in it, were not opposed by strong and independent forces, that no divine or human authority entered into competition with them:

Not the power of a citizenry which has been of such a fundamental importance in the Occident. The city in China lacked political autonomy: it was not a polis in the sense of Antiquity, nor was it a «commune» with political liberties of its own. Rather, it was the seat of a mandarin, without privileges of self-government or a charter. A citizenry in the Occidental sense could not develop here (RC: 13);

No estate of jurists and no formal jurisprudence, as it was developed in Roman law, nor a doctrine of natural law, for this would have presupposed a tension between philosophical or religious postulates and the «world» (RC: 148);

No ethical and asceticist religion which might have been able to shatter the fetters of the sibs (RC: 237); 
No science in the Occidental sense, for the power of the logos, of defining and reasoning, as well as a systematic and naturalist thought failed to mature (RC: 150 ); 32

No independent hierocracy which, as in the Occidental Middle Ages, could have produced a tension between the sacerdotium (priesthood) and the regnum (political authority) (RC: 142);

And finally no socially powerful prophecy and no salvation religion conducive to an ethic of conviction and a methodical way of life and being able to shatter the fetters of the sibs. (RC: 95).

Therefore, Weber believed, the "strong cage» ${ }^{33}$ of prebendary interests, the cause of the ossification of the Chinese state, could only be shattered by military conquest of the country or by a successful military or religious revolution.

Such strong and independent forces did exist in the Occident and produced revolutions of major importance for the destiny of Western culture: the development of independent cities in Italy in the $12^{\text {th }}$ and $13^{\text {th }}$ centuries, the Netherland revolution in the $16^{\text {th }}$ century, the «glorious revolution» and bill of rights in the $17^{\text {th }}$ century, and finally the American and French revolutions of the $18^{\text {th }}$ century. They did not, however, exist in

32 N. Sivin («Chinesische Wissenschaft. Ein Vergleich der Ansätze von Max Weber und Joseph Needham.» in: Wolfgang Schluchter (ed.) Max Webers Studie über Konfuzianismus und Taoismus, Frankfurt a. M. 1983) wrote, with regard to the sciences in China, that contrary to the picture that Weber drew of them the sciences were sophisticated enough for us to be able to evaluate them at the same level as their contemporary European counterparts until the seventeenth century (Sivin: 354). However, the level of scientific achievements and sophistication in China, to which the monumental work of J. Needham draws attention, was not Weber's major concern when he wrote about Chinese sciences. He rather wanted to draw attention to the fact that the Chinese sciences were not systematic and were not an independent force which could compete with the bureaucratic attitude towards life (RC: 151). And this interpretation seems to be accepted by Sivin when he writes that the Chinese sciences were not integrated by anything corresponding to the scientia of the West, that there was no science in China but only sciences. It should be added that the continued existence of magic, although it was devalued by the higher strata, may have had some influence on Chinese scientific development. Magic does not include the awareness that its concepts or actions may be erroneous or falsified or submitted to critique as it is expected in the West. Vide: R. Horton «African Traditional Thought and Western Science» in: Rationality, Oxford: Blackwell 1979 pp. 131-171.

33 The use of the expression «strong cage of prebendary interests» (RC: 61) seems like a weak echo of the «iron cage» (PE: 123) of modern Western civilization. 
China, and, therefore, no elements of the specifically modern rationalism were standing in competition with the patrimonial bureaucracy.

\section{The Result: Puritanism versus Confucianism}

In a chapter entitled Result Weber compares the rationalism of Confucianism with that of Protestantism. To judge the level of rationalization of a religion, he says, there are two interrelated yardsticks. One is the degree to which the religion has discarded magic, the other is the degree to which it has systematized the relationship between God and the world and therewith man's ethical relationship to the world (theodicy or, in Asia, cosmodicy).

China did not divest itself of magic for the Confucian ethic never penetrated the masses; it was in fact one of the basic tendencies of Confucianism to preserve this magic garden, while, on the other hand, a complete disenchantment of the world was carried through by Protestantism. With regard to the systematization of religion, Weber mentioned that naive stand of Confucianism towards things of this world, as opposed to Protestantism's grandiose tension towards the world.

It is the fate of every religion which upholds ethical imperatives, to find itself at some point in a state of tension with the irrationalities of the world. At what points these tensions will set in, will depend on the respective salvational goals and on the paths or means of salvation, and the degree of religious devaluation of the world is not identical with the degree of its rejection in actual practice, for the world may be rejected as salvational goal but at the same time accepted as means of salvation.

Confucianism reduced the religious devaluation of the world as well as its practical rejection to an absolute minimum: all tensions between the imperatives of a supra-mundane God and a creatural world were absent ${ }^{34}$.

34 Thomas Metzger in Escape from Predicament, Neo-Confucianism and China's Evolving Political Culture 1977 considered the denial of the existence of any transcendental tension to be a major error in Weber's interpretation of China. Particularly the Neo-Confucian tradition which was not treated by Weber in any detail, contained, as Metzger tried to show, the awareness of tension between the cosmic ideal and the worldly reality (a tendency towards transcendence of the status quo), as well as the realization that all attempts of the Confucian sage in his search for perfection and to overcome that tension are inadequate. By having demonstrated that there was «tension» in Neo-Confucianism, Metzger believed that he had also 
This ethic of unconditional affirmation of and adjustment to the world presupposed the continued existence of magical religion while, at the same time, every form of salvation religion and of congregational religion was eliminated and every prophecy of a supra-mundane God who raises ethical demands, was absent.

A true prophecy, says Weber, creates and systematically orients conduct toward one internal measure of value. Confucianism, however, favoured adjustment to the conditions of the world, it did not require a systematic unity of conduct which in the Westerner's mind is associated with the idea of personality (RC: 235), but rather a combination of useful particular traits: not an inner- but an outer-directed personality.

The duties of a Confucian always stressed the piety toward concrete people, never toward a sacred cause or an idea. They tied him to his sib members, not to functional tasks or enterprises. In contrast, the ethical religions like Protestantism shattered the fetters of the sib and established communities founded solely on their common ethical way of life.

As opposed to the adjustment to the world of Confucianism there is, according to Weber, the rejection of the world of Puritanism, a rejection which did not lead to a flight from the world but rather to rationalization of the world. The world was rejected by the Puritans as a goal of salvation but it was a means of proving one's self in successful enterprise.

While, on the whole, China produced different kinds of capitalism (politically oriented capitalism etc.), it did not develop modern capitalism out of its own sources. ${ }^{35}$ Weber reminds us that neither acquisitiveness nor

shown that there has been continuity in China between tradition and modernity because tension belongs to modernity. Weber's interpretation, on the other hand, would imply that there has been a complete break with the Chinese tradition since the Communist revolution. Metzger's standpoint seems to imply a modified Protestant ethic thesis: the researcher tries to find tension within a religion or culture and, if he succeeds, this indicates why that culture is or was able to modernize (although not necessarily able to produce modern capitalism from within itself).

35 This does not mean, of course, that China or the Chinese would not be able to adopt capitalism from the outside. Weber wrote one hundred years ago that the Chinese "in all probability would be quite capable, probably more capable than the Japanese, of assimilating capitalism" (RC: 248), for he distinguished clearly between invention and diffusion. Gordon Redding (1993) has described the «spirit» in successful overseas Chinese family businesses as based on paternalism, networking and filial piety, not on individualism. The ideas of the key actors are clearly linked to cultural (Confucian) sources while they live within a Western-influenced economic structure with legal, financial and commercial institutions. It 
high esteem for wealth nor utilitarian rationalism have any connection as yet with modern capitalism. Rationalism was embodied in the Confucian as well as in the Protestant «spirit». But while Confucian rationalism meant rational adjustment to the world, Protestant rationalism meant rational mastery of the world.

In comparison with the Occident, there were many conditions which externally favoured the origin of capitalism in China. On the other hand, many circumstances which hindered capitalism in China, similarly existed in the Occident. Therefore, according to Weber, we have to conclude that the mentality, i.e. the «Confucian spirit» had effects strongly counteractive to capitalist development.

\section{Intermediate Reflection: Religious Rejections of the World and their Levels and Directions}

Basic Literature

«Religious Rejections of the World and their Directions» in From Max Weber (translated and edited by H.H. Gerth \& C.Wright Mills) Oxford \& New York: Galaxy 1958, pp. 323-354

«Zwischenbetrachtung» in Max Weber Gesammelte Aufätze zur Religionssoziologie I, Tübingen: Mohr (Siebeck) 1920 pp. 536-573

India which will be considered next, is, in contrast to China, the cradle of the most world-denying forms of religious ethics. Before turning to her religions it must first be clarified in a schematic way which are the motives from which world-denying religious ethics have originated and in which directions they have developed.

The constructed schematic picture will indicate conflicting life-orders in an ideal-typical way. The theoretically constructed types of life-orders are prepared with a rational consistency which is rarely found in reality. To this extent, the construction will be ideal-typical in order to facilitate a clear general view and a precise terminology. But it is also true, as Weber insists, that rationality, in the sense of logical or teleological «consistency» of an intellectual or ethical attitude, has some kind of power over

may be asked whether the authoritarian capitalism of present-day China, lacking an impartial bureaucracy which has no clear idea of acting sine ira et studio, would increase its stability by revitalising the Confucian spirit. 
$\operatorname{man}^{36}$ (FMW: 324): religious interpretations of the world and ethics of religions created by intellectuals have been strongly exposed to the imperative of consistency even if they integrated points of view which could not be rationally deduced. Thus, the presentation of the otherwise multifarious reality will be facilitated by the idealtypical construction of the internally most consistent forms of ethical conduct that can be deduced from the given conditions.

Above all, these lines are intended as a contribution to a typology and sociology of rationalism. The argument proceeds from the most rational forms reality can assume, and then asks to what extent certain rational conclusions, pertaining to the conduct of life, were drawn or why they were not drawn.

Weber returns to the conception of a supra-mundane God (as in the Introduction) and notes that this conception, in spite of its affinity to emissary prophecy, did not operate alone in the production of an ascetic religious ethic (in opposition to a contemplative and mystical quest), but that this was possible only in conjunction with the nature of the religious promises and the paths of salvation which they determined. In this context, the polar concepts «asceticism» and «mysticism" need to be clarified.

Both asceticism (action in conformity with the demands of God; the actor considers himself as God's tool) and mysticism (the individual considers himself not as a tool but as a «vessel ${ }^{37}$ which is in contemplative possession of the divine; action in the world appears as endangering the otherworldly religious state) are forms of world rejection. Asceticism contrasts radically with mysticism if asceticism operates within the world and tries to master the world (inner-worldly asceticism) and if mysticism draws the

36 This is a theme which Weber alluded to on several occasions. In the Protestant Ethic (PE: 56) Weber had already mentioned that in order to understand the specific importance and influence of religious ideas, one has to study their most consistent and logical forms. In the replies to his critics (AC: 113) he wrote: the style of life of the ascetic communities in confessionally mixed regions rubbed off on the style of life of the other denominations; an assimilation to the most consistent expressions of Protestant ascetism almost always took place.

Even in the field of legal doctrine one can, according to Weber (ES: 789), discover the power of pure logic on legal practice.

37 The poet Rainer Maria Rilke whom Weber regarded highly and about whom he commented in 1910 in a letter to his sister Lili, calling him a mystic (MWG II, 6: 615), wrote in 1899 in the collection of poems entitled Stundenbuch (Book of Hours): 
full conclusion of fleeing from the world (world-fleeing mysticism). The contrast is tempered, however, if the ascetic confines himself to overcoming the creatural wickedness in his own nature and enhances his active redemptory accomplishments to the point of avoiding any action in the world (world-fleeing asceticism) or if the contemplative mystic does not draw the conclusion that he should flee from the world (inner-worldly mysticism). But always, even when the mystic accommodates to the orders of the world, he resists the temptation to take the ways of the world seriously. Like Lao-tse, he proves himself against his action in the world and not, like the inner-worldly ascetic, through his actions. Moreover, Judaism and Islam with their transcendent god developed mysticism but hardly any asceticism. Quite obviously, the concept of a transcendent god, in spite of its affinity to active asceticism, did not operate alone but rather in conjuction with other circumstances, particularly the religious promises and the paths of salvation which they determined.

After these remarks on the polar concepts of asceticism and mysticism Weber considers the tensions existing between religion and what he terms the other orders of life. A methodical conduct of life which may form the germ of either asceticism or mysticism, originally grows out of magical preconditions. The magician has been the historical precursor of the prophet. But while it is true that the prophets legitimized themselves through the possession of a magical charisma, it was the substance of their prophecy to direct their followers' conduct of life to the pursuit of a salvational good. This has been particularly so in the case of «salvation religions» that promised deliverance from suffering to their adherents. The more inward, the more principled the essence of suffering was conceived, the more it was important to attain a permanent state which would guarantee salvation.

Such religions have lived in a permanent state of tension in relation to the world and its orders. The tension has been the greater, the more rational the ethic has been and the more the original ritualism was sublimated towards a «religion of conviction». Equally, the further the rationalization

What will you do, God, if death takes me,

I am your vessel, if Time brakes me,

I am your drink, if curdling cakes me,

You 'll lose all meaning losing me.

Perhaps Weber found here the image of the mystic as a vessel or jug of God? 
and sublimation of the possession of «worldly» goods proceeded, the stronger has the tension on the part of religion become, for this development made conscious in the minds of the individuals the inner logic (Eigengesetzlichkeit) of the religious and worldly spheres and the consequences of these different inner logics. This is a typical result of the conscious endeavour towards rationality. Weber now considers a series of these recurring tensions.

To begin with, there was the tension between salvation religion and the traditional sib. For it was taken for granted in the prophetic religions of salvation that brothers in the faith should, in the last analysis, be closer to each other than to their relatives in the community into which they were born. Shattering the magical ties and the exclusiveness of the sibs, they created a new community characterized by a religious ethic of brotherliness. The original distinction between in-group and out-group morality was transferred to the religious community and the members were required to help the poor and the sick of the community; but, the more rational the idea of salvation became and the more it was sublimated into an ethic of conviction, the more the barriers of faith and even the existence of hatred were conceived as the result of suffering and of the imperfections of empirical reality. Therefore, the ethical demand has tended towards an objectless acosmism ${ }^{38}$ of love, a universalist brotherliness which broke all barriers of societal associations and often also the barriers of one's own religious community. The more consistently the demands of this religious brotherliness have been carried through, the sharper they clashed with the orders and values of the world. This clash became the wider the more the values of the world have been rationalized according to their own inner logic.

This became particularly obvious in the economic sphere. A rational economy is a functional organization, depending on monetary calculations. Money is the most abstract and «impersonal» element in human life. The modern rational capitalist economy, therefore, is not accessible to a religious ethic of brotherliness, and the salvation religions have always watched the impersonal economic activity with profound suspicion for, as

38 In philosophy the term «acosmistic» is used for a system of thought which denies the existence of a cosmos outside of God or the devine. Weber uses the term to designate mystical world rejection and generally any religiosity which rejects the possibility to have an active and formative effect on the world and which, while disregarding reality and social orders, obeys the rule of brotherly love. 
mentioned in Weber's «Protestant Ethic», deo placere non potest (it cannot please God).

The most radical rejection of individual economic property can be found in the world-fleeing asceticism of monks. And yet, the paradox of all rational asceticism which often creates the very wealth it rejects, has made monks in all ages stumble: monasteries everywhere became the very loci of rational economic activity.

There are, according to Weber, only two consistent avenues for escaping the tension between salvation religion and the economic sphere in a principled and inward manner: the Puritan vocational ethic which renounces all universal love, serves God's incomprehensible and positive will and accepts the depersonalization of the economic cosmos as Godwilled. In truth, this standpoint of unbrotherliness was no longer a genuine salvation religion. The other consistent avenue is the mystic acosmism of love, the giving to anybody who accidentally comes one's way, the objectless devotion to anybody, not for the person's sake but for devotion's sake.

Thirdly, there developed tension between the religious ethic of brotherliness and the political sphere. While the religion turned to a God of love and demanded an ethic of brotherliness, the bureaucratic state proceeded without regard to the person, sine ira et studio (without either hatred or love) and thus conflicted with the religious demands. Moreover, every state's absolute end is to safeguard itself, if necessary by the appeal to naked force, - indeed, the state is an association that claims the monopoly of the legitimate use of force -, and accepting the responsibility for any possible injustice, ${ }^{39}$ contrary to the teaching of the Sermon on the Mount not to resist evil.

And as force generally breeds more force, the «reasons of state» tend to follow the tracks of their inner logic. The more matter-of-fact and the more effective politics is, the less brotherly it will appear to a rationalized ethic of brotherliness.

39 The translation of this passage in FMW: 334 is quite flawed. It suggests that there might sometimes be injustice if the state does not intervene by force. Weber, on the contrary, suggests that there might be injustice in any case, but that the politician, as he pursues an ethic of responsibility and not an ethic of conviction, has to shoulder any possible injustice resulting from his actions. On the distinction between the ethic of responsibility and the ethic of conviction vide Weber's «Politics as a Vocation» in FMW: 77-128, particularly p. 120. 
There are only two solutions of the tension between religion and politics: 1. The Puritan belief that the commandments of God should be imposed by force on the creaturely world in the interest of God's cause, and 2. the mystic's radical acosmistic brotherliness which, with the maxim «then turn the other cheek» of the Sermon on the Mount, withdraws from the pragma of violence which no political action can escape. Some compromise solutions, however, may be of interest as types. Lutheranism, for instance, has rejected the right to active resistance against any secular coercion in matters of faith and has known only passive resistance in this matter. It also accepted obedience to secular authority, even if it had given the order for war - and it thus accepted its ethical autonomy. Luther's religiosity was, like all mystic search for salvation, apolitical or anti-political, but he stopped short of drawing the full conclusion: he did not infer consistently the radically diabolic character of the world.

The use of religious organizations for the political domestication of the masses or for the religious consecration of the legitimacy of those in power were, of course, forms of the relativization of religious values and of their inner logic. The most important type of these relative forms has been the «organic" social ethic, whose conception of vocational work has been the most important contrast to the idea of the calling, as found in innerworldly asceticism. The organic social ethic rejects the idea that salvation should be accessible only to some and not to all and it attempts to synthesize the inequality of charismatic qualifications with the secular social strata into a cosmos of God-ordained services. It thus comprehends the world as an at least relatively rational cosmos, but it also represents, from the point of view of the acosmistic ethic of brotherliness, an accommodation to the interests of the privileged strata and, on the other hand, from the point of view of innerworldly asceticism, a lack of a rational-methodical conduct of life.

While the organic social ethic is eminently conservative, a virtuoso religiosity may have revolutionary consequences. Inner-worldly asceticism, whenever it opposes a divine «natural law» to a given political order, leads to Puritan revolutions and to the obligation to crusade. In the case of the mystic, on the other hand, when the possession of God turns into possession by God and when eschatological expectations of an acosmistic and brotherly millennium appear, this may lead to chiliastic anomism.

Also every other rational action (apart from economic and political action) carries within itself a profound tension. It results from the question whether the value of an action lies in the action per se or whether it should 
be determined by its success. The attitude, resulting from an ethic of conviction, «to do right and to leave the success to God» will, because of the inner logic of the world, prove irrational in its effects - as has been shown theoretically in the Bhagavadgita, a part of an Indian epos.

Fourthly, there is tension between the ethic of religious brotherliness and the spheres of esthetic and erotic life. Magical religiosity (with its idols or ecstatic dances) stands in an intimate relation to the esthetic sphere, but for the religious ethic of brotherliness art as a carrier of magical effects in suspect. Salvation religions have stressed meaning and have devalued form, and they have completely rejected art, when it takes over the value of this-worldly salvation. In religion's eyes, such inner-worldly salvation is no more than irresponsible indulgence and secret lovelessness.

Besides, in our intellectualistic age men tend to avoid moral judgements or to transform them into judgements of taste («in poor taste» instead of «reprehensible») - and this may very well be regarded by salvation religions as a very base form of unbrotherliness.

On the whole, universalist mass religions have always entered alliances with art, but genuine virtuoso religions have clearly shown their reservations.

Also sexual love was very often part of magic orgiasticism, but most prophetic religions have regulated it in favour of marriage and they thus expressed the contrast between a rational conduct of life, on the one hand, and magical orgiasticism and all sorts of irrational ecstasies, on the other. But when, later, sexuality was sublimated into «eroticism», it appeared as an escape from the mechanisms of rationalization, as equivalent to the «having» of the mystic, and extramarital sexual life appeared as the only tie which still linked man with the natural fountain of life.

A principled ethic of brotherliness is radically opposed to this kind of innerworldly salvation. Inner-worldly and rational asceticism can accept only the rationally regulated marriage, best demonstrated perhaps in the Quaker ethic of William Penn ${ }^{40}$ which underscores the ethical responsibil-

40 Weber here mentions the letters of William Penn to his wife. It is perhaps noteworthy that Weber more than once quoted letters of famous men to close female friends: for instance the letters of the German poet Goethe to Frau v. Stein (Critical Studies in the Logic of the Cultural Sciences, CMW: 154 sqq); and the letters of Abélard to Héloise (RC: 168). The three volumes of Weber's Collected Essays in the Sociology of Religion were dedicated to three women close to him: his wife Marianne as well as Mina Tobler and Else Jaffé-Richthofen. 
ity for one another and which rejects all eroticism as idolatry of the worst kind.

Finally, the tension is greatest and most principled where the religion of salvation faces the sphere of intellectual knowledge. Wherever rational empirical knowledge has disenchanted the world, it unavoidably meets the claim of the ethical postulate that the world is a somehow meaningfully organized cosmos. As the empirical as well as the mathematically oriented view of the world rejects all questions which inquire about the «meaning" of inner-worldly occurrences, they tend to push religion from the rational into the irrational realm. Although religions again and again have tried to justify and to rationalize their dogmas, the fundamental inner tension which at some point demands the "sacrifice of the intellect", proclaiming credo non quod sed quia absurdum (I believe - not what is absurd but because it is absurd), could not be resolved. For salvation religion does not claim to offer intellectual knowledge, it offers an ultimate stand towards the world by virtue of a direct grasp of its «meaning».

The directions of world rejection and of the striving for salvation which have been discussed so far, depended on the question which spheres of the "world" had been rationalized or had been left to their inner logic (the tribal, economic, political, aesthetic, erotic or intellectual sphere). Proceeding from the religious claim that the course of the world is somehow meaningful, Weber now tries to construct a theory of the degrees of world rejection. The claim emerged first in the context of the customary problem of unjust suffering, but it then progressed to an ever-increasing devaluation of the world. For not only unjust suffering, but the existence of suffering as such soon appeared to be irrational: the world itself was conceived as imperfect. That an imperfect world may not be eternal, appeared reasonable; but then this transitoriness devalued the highest inner-worldly goods so that the whole empirical world was rejected. Even the most highly cherished cultural values were indicted for they run counter, as has been seen, to the demand for brotherliness, they are characterized by the unbrotherly charisma of the mind and of taste and the impersonality of the economic cosmos.

Furthermore, something will adhere to the possession of cultural values which is bound to depreciate them with still greater finality: their meaninglessness. The inner-worldly perfection and cultivation of self is meaningless because death is meaningless when viewed from the inner-worldly standpoint. The man of culture cannot die "satiated with life" like the peasant, for, just as his cultural values, his perfectibility in principle pro- 
gresses indefinitely; and the more differentiated the cultural values become, the more it appears unlikely that he has achieved a meaningful selection at the moment of his death. Thus culture or the striving for it cannot have an inner-worldly meaning. Even all intellectual and mystical attempts at salvation in the face of these tensions succumb in the end to the reign of unbrotherliness, because their charisma is not accessible to everybody and also, because under the social conditions of rational and vocational work only the economically independent strata can afford to lead the life of a Buddha or a Jesus.

The various ethics of salvation choose different points of departure for their world-rejection on this purely rationally constructed scale. Besides other circumstances, a rational element, the respective theodicy, does play its part. Among the three consistent types of theodicy there is, to begin with, Zoroastrian dualism which maintains the coexistence of the powers of light and darkness. Its consistent form which involves renouncing the omnipotence of a god, has been given up by most mass religions and has been replaced by a less consistent form in which the god of light finally triumphs over the god of darkness. While this conception restores God's sovereignty, it willy-nilly sacrifices some of the divine love because it admits a (subordinate) power of darkness, sin and hell's punishments.

In that case, only renunciation of God's love and benevolence, as in the Puritan dogma of predestination, is consistent. Man's acknowledged incapacity to understand the ways of God means that he renounces any accessibility to a meaning of the world. Outside of a circle of virtuosi the belief in this consistent dogma has not been permanently endured.

The third form of consistent theodicy was peculiar to the religiosity of Indian intellectuals and world renouncers. It stands out by virtue of its combination of strict world-rejection with an organic social ethic, of contemplation with an inner-worldly vocational ethic. It is to this Indian religiosity that Weber now turns.

\section{Hinduism and Buddhism}

\section{Basic Literature:}

Max Weber, The Religion of India. The Sociology of Hinduism and Buddhism, New York: The Free Press 1958 
Max Weber, Gesammelte Aufsätze zur Religionssoziologie II, Tübingen 1921

Wolfgang Schluchter, Rationalism, Religion, and Domination University of California Press 1989 Chapter IV Hinduism and Buddhism: World Flight and Organic Relativism)

Wolfgang Schluchter (Hg.), Max Webers Studie über Hinduismus und Buddhismus, Frankfurt a.M. 1984

The structure of Weber's essay on «Hinduism and Buddhism» is quite similar to that on «Confucianism and Taoism». After some introductory comments regarding the fact that India has always been a land of trade, that the princes pursued rational financial policies, that the political capitalism of tax farming and state contracting was well known and that Indians had cultivated rational science in some areas (including mathematics), Weber nevertheless notes that modern capitalism did not develop indigenously but is an imported product. This raises the question as to whether Indian religiosity, as one factor among many, may have been responsible for the absence of modern capitalism. In order to answer this question, Weber first analyzes the Indian social system and then the «spirit» which lived in it.

\section{The Hindu Social System}

While in China the patrimonial bureaucracy was the dominating social structure, the shell (Gehäuse) in which the Confucian spirit lived, in India everything revolved around the caste system in which, in turn, there lived the Indian spirit. But what is a caste? Weber approached the notion by comparing it with other social forms. In contrast to a tribe, a caste is without a fixed territory nor does it form a political body. Moreover, the admissible kinds of occupation of caste members are strictly limited. This leads to a comparison of the caste with merchant and craft guilds. Here it must be stressed that membership in a caste is hereditary and that the «spirit» of the caste system was totally different from that of the guilds. The Occidental medieval city rested on the fraternization of the guilds and of the citizenry. Since Paul's letter to the Galatians (II, 12 sqq.) Christians had shattered, according to Weber, the voluntary ghetto of the Jews, the ritual barriers against commensality at the Holy Communion. This had been the hour of conception for the Occidental citizenry. The Indian caste order, on the other hand, excluded the possibility of commensality as well as the connubium (marriage between members of different castes). There- 
fore, the possibility that town dwellers became citizens in the medieval Western sense did not exist and the corporate character of the city was unknown (ES: 1228). Nevertheless, castes are, according to Weber, status groups, if status implies a quality of social honour or a lack of it, and expresses itself through a specific conduct of life - even if the status differences of the castes are easily transposed into the magico-religious sphere.

And how were the castes combined into a caste system? Weber starts from the classical brahmanical theory which divides the system into four varnas (categories), the brahmins (representing the sacerdotal status), the ksatriyas (representing the political power), the vaishyas (representing commerce and trade) and the shudras (servile occupations), and thus establishes a hierarchical ${ }^{41}$ succession of ranks; but he leaves no doubt that the relative ranks between concrete castes were always and everywhere disputed. The concrete system was not established once and for all but was continuously submitted to change in the various local and political situations. Considered over a longer time period, its importance seems to have increased.

Kings naturally belonged to the ksatriyas. Their administratiion was patrimonial-bureaucratic, the responsibilities of the administrators (often the kings» relatives) were fluid. The kings often claimed monopolies in trade, and tax farming arrangements evolved into prebends and not fiefs. A prebendalization of the patrimonail state occurred (RI: 67-71).

Weber sees the origin of the caste system in the importance of the magical lineage charisma, reinforced by the existence of several races (RI: 126). This social situation favoured a division of labour based on the concept of guest peoples - with an external resemblance to the helots of the Spartan state in ancient Greece. The brahmins were in a position - without any formal organization and although they depended on the political pow-

41 The meaning of «hierarchy» with regard to India has received a modified and more nuanced interpretation by Louis Dumont in his Homo Hierarchicus. It does not consist of units of successive orders or of a ladder of command as in a modern army or in modern bureaucracy. Rather, it here implies a holistic and relational view which gives everything its value and characteristics in relation to the englobing whole. Thus, this view valorizes the social whole and subordinates the human individual or the individual group. The opposition between brahmin and ksatriya, for instance, is a hierarchical one in which the brahmin is superior to the ksatriya although he depends on him materially, because the religious sphere is englobing the political sphere, or, put differently: brahmins are superior because they are inferior only at an inferior level. 
er of the kshatriyas - to occupy an eminent place in this system. Partially, this may have been the result of the fact that the great Hinduistic patrimonial empires found support of their legitimacy among the brahmins, partially also because the patrimonial rules supported the caste system in order to limit the power of the guilds, and finally because the Islamic conquest since the tenth century reduced the political power of the ksatriyas and thus implicitly supported the position of the brahmins. For all these reasons the caste system slowly became dominant.

\section{The Hindu Spirit}

The system had, according to Weber, a traditionalistic and anti-rational effect in the economic sphere - not because ritual caste antagonisms made the development of large enterprises impossible or because of other related difficulties, but because of the «spirit» which lived in the whole system (RI: 112).

Hinduism is generally a very tolerant religion with regard to dogma and teachings, but it stresses the ritual duties (dharma) of the castes. No Hindu rejects the two central doctrines: samsara (the transmigration of souls) and karma (the doctrine of compensation for one's actions), according to which the human fate and one's position within the caste system is determined by the fulfillment of ritual and ethical duties in one's previous life. This karma doctrine was, according to Weber, the most consistent theodicy ever produced in historical times. It promised the highest premium for the fulfillment of one's caste duties: rebirth in a higher caste, perhaps even as a king or as a god.

This brilliant combination of ritual caste duties and caste legitimacy with the karma doctrine was the product of rational ethical thought and not of economic conditions (RI: 131); and only the wedding of this thought product with the real social order by means of the promise of rebirth gave this order the irresistible power over thought and hope of the people. The devout Hindu, even if he was not conscious of this grandiose context, was a captive in this intellectual and social cage (RI: 121). Action according the the caste dharma had salvational significance. In the context of these concepts, however, ideas of progress or revolution were inconceivable; work was prescribed by tradition and the rationalization of economic life an impossibility. 


\section{Orthodox and Heterodox Salvation Teachings}

If one wanrs to understand the brahmins, a comparison with the intellectuals of other cultures is unavoidable, in particular with the intellectuals of the Greek polis and with the Confucian mandarins.

In contrast to the intellectuals of the polis, the brahmins were tied to ritual and magic. On the other hand, both mandarins and brahmins were a status group of genteel literati whose charisma rested on «knowledge»; both rejected all types of orgiasticism and all irrational forms of salvation. But in China we find a stratum of officials and candidates for office, whereas careers in office were not typical for the brahmins who could be princely chaplains, teachers, jurists, priests and sometimes even farmers. The Chinese patrimonial bureaucracy did not recognize other autonomous forces whereas the Indian brahmins stood independently beside the political rulers.

The brahmins had their own duties (svadharma), different from those of the political rulers; both followed the inner law (Eigengesetzlichkeit) of their respective castes. There was no universally valid ethic, no natural law, no natural equality of human beings, no concept of radical evil, no concept of the state (RI: 144). Only the caste dharma existed, the inner law of the respective castes. It was the dharma of the brahmin to perform sacrifices and other priestly activities and it was the dharma of the kshatriya to conduct wars for the sake of pure power and, if necessary, by cunning and fraud, which led to an astonishing Machiavellianism unheard of in the Occident (RI: 146). The same can be said about other areas of life: in contrast to the rejection of specialization in Confucianism, Hinduism accepted the special knowledge and inner laws of all spheres of life: the conduct of war and administration became specialized fields of knowledge and there existed a rational science in mathematics and grammar.

The seemingly so consistent and well-rounded picture of caste society and karma theodicy in which the goal of salvation of each person is a better rebirth and in which the means of salvation is action in conformity with one's caste dharma is, however, relativized by Weber by the observation that the «wheel» of recurrent rebirths and deaths must appear meaningless to the human being. The question arose how one can avoid or escape the transitoriness of life.

Therefore, besides the conduct of life according to one's caste dharma, there was the alternative of the conduct of life of the sramana, the world renouncer who, leaving the holistic social order by renouncing his existing 
rôle in society (as a member of a caste, family etc.) and sometimes living alone in the wilderness, tried to achieve salvation from the wheel of rebirths as an outworldly individual. Ritual and virtuous actions within the caste order might improve the rebirth chances, but true salvation could only be achieved by world fleeing asceticism or contemplation (RI: 152). The sramana relativized the innerworldly goals of salvation by his radical rejection of the world, the desire to be saved from the world itself - and this not only because suffering devalues all creatures but because of an aversion to the world's meaningless turns and changes.

This state of affairs, full of inner consistency, was by no means universal, for the belief in fate or in an all-powerful god - both not logically compatible with the karma theodicy - can also be found. But the juxtaposition of caste dharma and the striving for otherworldly salvation produced a tension, said Weber, which was the root of orthodox as well as heterodox solutions.

One such solution can be foud in the Bhagavadgita, a religious poem inserted in the Mahabharata epos and of almost canonical significance for orthodox Hindus. The question is asked in what sense actions according to the caste dharma can have salvational significance, and the originality of the Bhagavadgita can be found in the answer that the man of knowledge should keep an inner distance from his innerworldly duties, that he should act in the world according to his dharma, but without ever seeking success and the fruits of his actions. This indifferent attitude towards innerworldly conduct represents, according to Weber, the crown of classical ethics of Indian intellectuals (RI: 185), although he does not attribute to it a complete inner consistency ${ }^{42}$ for there remained the question of the relative significance of action in the world while disregarding the results. In this inner-worldly mysticism (as opposed to world fleeing mysticism) both paths of salvation, right knowledge and right action, seem to be of equal rank. In any case, the fulfillment of the caste dharma was, according to the Bhagavadgita, rigidly traditionalistic as an activity in the world but not of the world (RI: 326).

Another response was Jainism which originated among intellectual kshatriyas at the time of the development of cities. It rejected the ritualistic

42 According to Weber, there are only two consistent solutions to the tensions between salvation religion on the one hand and the political and economic sphere on the other: the Puritan ethic and the acosmism of the mystic. All other solutions are compromises and relativisations. 
commandments and teachings of Hinduism's holy books, the Vedas, Just like in orthodox Hinduism, knowledge was the supreme means of salvation, but the path to salvation was asceticism to a much higher degree than in other sects (RI: 195). Jainism produced the typical dualistic organization of Hindu sects: a community of monks as the nucleus and the laity under the religious domination of the monks. This laity had to take special vows to fulfill obligatory duties and thus had the typical character of a sect into which one is especially received.

At the top of all ascetic rules was ahimsa (prohibition of the killing of living beings) which largely excluded the Jainas from many occupations, particularly agriculture as ploughing endangers the the life of worms and insects (RI: 199). This was followed by satya (to be free from falsehood) and, even for the laity, by aparigraha (to be free from worldly attachments or the limitation of possessions). While the acquisition of wealth was not forbidden, the attachment to riches was frowned upon - in a way similar to the Protestant ethic ${ }^{43}$ in the Occident (RI: 200). Furthermore, all deception and dishonest gain was prohibited. Only traders and bankers could truly practice ahimsa. The compulsory saving, familiar from ascetic Protestantism, worked also among the Jainas as they used accumulated possessions for investment rather than consumption, but they remained confined to commercial capitalism and banking and did not create indus-

43 It has been a recurring tendency to compare Jainism with Protestantism (already G. Bühler in Deutsche Revue 1894, vol. 19. 4, p. 223 sqq. drew a parallel between the Jainist organization and the Free Kirk of Scotland, later Glasenapp 1964: 331, and fianally B. Nevashkar in Capitalists without Capitalism. The Jains of India and the Quakers in the West. Westport, Connecticut: Greenwood 1991). In general, recent scholarship does confirm, while adding new aspects, Weber's interpretation of Jainism. Jainas believe that existing karma needs to be destroyed by the observance of austerities, tapas, (vows of fasting, giving up any attachment to the body etc.), and that they alone are expected to work out their salvation: no amount of intercession by others or even higher beings is helpful. A lonely individualism, similar to that of the Puritans, may be the result. But, on the other hand, there is the distinction between monks (sadhu, swami) and lay people (the rules prescribed to these two groups differing not in kind but in degree) which does not exist in the Protestant sects; the caste system is not absent, there is idol worship among at least some sub-sects, and the philosophical doctrine of syādvāda (the theory of the relativity of truths according to which contradictory statements may be true at the same time) seems to relativize the requirement of truthfulness itself.

It might be mentioned in passing that, according to Weber, also the Parsis (of Zoroastrian origin) are prosperous as businessmen because of their adherence to the rigid injunction to be honest (ES:556). 
trial orgnizations - perhaps because of the barriers set up by the patrimonial character of kingship.

Weber believed that the teaching of the Jainas contained an inner contradiction, for their highest goal was an inner habitus of tranquillity - as with all Indian soteriologies of intellectuals - (RI: 204), the path to its attainment, however, was detachment from the world and self-denial through mortification; but such asceticism does not easily lead to a feeling of security and tranquillity. In spite of the separation of monks and lay adherents, there was no separate goal of salvation for the lay community. Magic was never completely cast off, and the anxious control of ritual correctness prevented an inner rationalization and a coherent method of contemplative mysticism or active asceticism. After the Hindu Restauration Jainism did not escape the fate of Hinduization and the caste order took hold among them.

\section{Ancient Buddhism}

Early Buddhism, to which Weber then turned, is described systematically with regard to the points important to him, and as a coherent system of thought, even if at its beginning it may not have had such a rational consistency (RI: 206). Just as Jainism, it originated during a time of urban development and, as a soteriology of cultivated intellectuals, it was the product of positively privileged status groups. Kshatriyas, brahmins and rich citizens were its adherents, and the Buddha, himself a kshatriya, was in Weber's view, an exemplary prophet ${ }^{44}$ and not, like Mohammed or Jeremia, an emissary or ethical prophet. Ancient Buddhism represents the polar opposite of Confucianism and of Islam: it was an apolitical and even anti-political religious theory of salvation of intellectually schooled mendicant monks.

The goal of salvation was, as with all Indian intellectual soteriologies, internal peace; all means of salvation which were not directly related to this goal were eradicated - as for instance the ascetic characteristics of Jainism and all philosophical speculation. Buddhism did not doubt the common Indian karma theodicy and the belief which followed from it that

44 India seems to be characterized by exemplary prophecy until the time of Mahatma Gandhi. This kind of prophecy does not lead to any revolution (which would be contrary to the caste spirit) but at the most to passive resistance (ES: 447). 
salvation is the solely personal act of the single human being («be a lamp unto yourself», as the Buddha said). But it rejected the belief that there is a soul as a lasting unit. There is in Buddhist teaching no immortal soul and no God who gives commandments. Buddhist precepts are recommendations. Human beings consist of many factors or elements which all are impermanent. What appears to be a personality is simply a bundle of different factors which have combined into an apparent whole and which after the individual's death will combine into a new individual, just as if a light might pass from one lamp to another: nothing substantial passes from the former to the latter. ${ }^{45}$ What constitutes the individual is the will to exist, the «thirst» for life and actions, pleasure and power, producing new karma, illness and death. «Thirst» and acting, even good deeds, are obstacles to salvation, contemplation and inner enlightenment lead to bliss in the here and now. The person who has achieved this goal, the arhat, is free from fear and desire and has attained nirvana. There is no bridge between the arhat ideal and the world of rational action (RI: 213). In later Buddhist philosophy (Prajnaparamita) even samsara and nirvana are only conceptual constructions. There is a metaphor of crossing a river where Buddha's teachings are the raft which one does not need any more after the crossing so that the distinction between samsara and nirvana becomes meaningless. ${ }^{46}$ Neither is a reasonable object of desire and the sensible Buddhist will therefore desire nothing, said Vasubandhu (between 300 and 500 A.D.).

Salvation is thus an absolutely personal achievement and no one can help; there is no grace and no prayer. There is a certain contradiction in the fact that the Buddha who was quite aloof from forming a church or a community gave life to an order of monks, although the organization of this order was minimized intentionally and with great consistency. The monastic rules (quite different from the Benedictine ora et labora, namely pray and work) did not include work and they lacked what has been developed in Occidental monasticism: a rational conduct of life (except with regard to a systematization of meditation and contemplation). A rational economic ethic could hardly develop in this sort of religious order (RI: 216); there was only an ethic of non-action and of contemplation which

45 This metaphor is given in the Milinda Panha (Milinda's Questions 71.16), an old Buddhist text, translated by I. B. Horner

46 Heinrich Zimmer Philosphies of India Princeton University Press 1951, p. 474 sqq. 
alone was thought to provide salvation. Salvation by work was considered heretical.

Anyone who offered alms to the wandering monks could be considered as a member of the laity. The Buddhist lay ethic, an insufficiency ethic of the weak, as Weber called it, as they did not seek complete salvation, contained the prohibition against the killing of living beings (ahimsa) and promised innerworldly goods: riches and better rebirth chances. Any attempt to form a methodical lay ethic was lacking for any sort of religious premium for a specific economic behaviour was absent (RI: 219). Because of the lack of any kind of planned influence on the conduct of the laity there developed ritualism and hagiolatry. The acquisition of wealth was not forbidden, for wealth did not imply wrong, but it was thought to lead to the temptation to succumb to «thirst».

The Buddhist «acosmism of love», as Weber called it, was cool and egocentric. Just as in Jainism and in Puritanism the own salvation (certitudo salutis) was at the center of all preoccupations, not that of one's neighbour or the love of one's enemy. Buddhist altruism was not active brotherliness but just a step to the final goal: the stoic equanimity of the one who has achieved knowledge. If it is asked why ancient Buddhism became a missionary religion, the motive can be found in the material interests of the monks to increase the number of providers of food, of the lay population.

Ancient Buddhism had been the most consistent of the soteriologies of Indian intellectuals. Its inner consistency (and exterior weakness) had lain in the fact that it reserved salvation to the monks and hardly bothered about the laity. There was lacking what Jainism had produced, an organization of the laity. Soon after the expedition of Alexander, the patrimonialism of «world-reigning» kings (cakravartin) replaced the ancient petty kingdoms. Under the great king Ashoka the beginnings of Buddhist political theory emerged, particularly the ideal of the welfare state, welfare being understood as the increase of the chances of salvation and of charities, but not as rational economic welfare ${ }^{47}$. Moreover, the religious needs of the literate officials and petty bourgeois who did not wish to attain nirvana

47 The translation in RI: 242 is plainly incorrect; vide the original German text in GARS II, p.262 which states clearly that Ashoka's policy was not meant to be rational economic welfare.

With regard to Buddhist political theory the Anguttara Nikaya 4. 70 of the Buddhist Pali Canon states that if kings are without virtue, then officials will be with- 
needed to be satisfied, and the patrimonial ruler Ashoka saw in Buddhism - originally a religion of intellectuals - an instrument to domesticate the masses. ${ }^{48}$ As soon as Buddhism became a popular religion, it transformed itself into a saviour religion with hopes for the world beyond guaranteed by deeds of mercy and purely magical motives (ES: 628).

\section{Buddhism elsewhere in Asia}

Wherever Buddhism was diffused in the Orient, it considered the gods of the respective cultures as subordinate to the Buddha and it generally underwent some striking transformations. For emotional mass religiosity there are generally but two possible soteriologies: magic or a saviour (RI: 237). The necessary adaptation process produced the Mahayana version of Buddhism (as opposed to the earlier Hinayana). The idea of the Bodhisattva who, instead of entering nirvana, becomes a helper in need for life here and now, was developed. There also appeared, besides the world-fleeing mysticism of early Buddhism an inner-worldly mysticism, the idea of a world-indifferent life which proves itself within and against the world - a Buddhist version of the ideas of the Bhagavadgita (RI: 253). But a rational inner-worldly conduct of life was not to be established on the basis of the Mahayana. Miraculous and magical interventions of the Bodhisattvas predominated, and the world remained a magic garden.

The Buddhism of Ceylon developed from the ancient Buddhist orthodoxy. Monastic landlordism was supported by kingship based upon a magnificent irrigation system and the requisite bureaucracy. Buddhist lay rules were not very demanding, belief in demons and magic art dominated

out virtue, and then also citizens and peasants will be without virtue. And then it will not rain, seeds will grow poorly and humans will get ill.

48 In an interesting article, the indologist Heinz Bechert has given an evaluation of Weber's view of Buddhism. According to him, Weber's assessment of primitive Buddhism was surprisingly correct, and also still pertinent is Weber's description of the factors that caused the transformation of the old soteriology for intellectuals into a religion of the masses. But Weber's treatment of the later development of Buddhism is India was unsatisfactory. Among Bechert's critiques is Weber's comparison between the Indian emperor Ashoka and the Byzantine rulers and Weber's overlooking of the graded character of the Buddhist ethic regarding monks and laymen. (Heinz Bechert «Max Weber and the Sociology of Buddhism» in: Internationales Asienforum vol. 22 (1991) no.3-4, pp. 181-195). 
their life. In the outlying Indian territories of Burma and Siam the Hinayana may well be co-responsible for the inferior technical and economic development which it tolerated at best. The monasteries were not places of rational work and the absence of castes in these territories had a negative effect on the lay population, for, although they do not lead to modern rational development, castes do at least motivate a traditonal loyalty to one's vocation.

Mahayana Buddhism spread in China where it encountered the Confucian stratum of literati. The policies of the Chinese government towards Buddhism wavered between support, toleration, quota regulations, confiscation of temple treasures and violent persecutions. Buddhism here was of a rather plebeian character, the monks belonged to the non-literary strata, the monasteries were places of irrational ascetism, and meditation and pagodas were apotropaic means to defend against demons. Any beginnings of a systematic ethical rationalization of conduct of the laity were out of the question (RI: 268) ${ }^{49}$

49 These affirmations are too short and sweeping, for Weber practically ignored the rich Chinese Buddhist tradition,. While it is true that the Chinese nobility and literate families did not embrace the ways of the Indian renouncers and begging monks, they were impressed by the reinterpretation of Buddhism by the life style of Vimalakirti, a rich aristocrat who denied himself no luxury, "who wore the white robe of the layman, but lived according to the rules of monks, who lived in a house, but kept away from the world of desires» (E. Lamotte L'enseignement de Vimalakirti, Louvain 1962 p. 127). It also appears that Buddhism brought a universal ethic to the prevailing familism and particularism of the indigenous traditions, according to A. F. Wright in: Buddhism in Chinese History, Stanford University Press 1959 , p. 75 . Li (order) was now interpreted as the transcendental absolute as opposed to the empirical data of experience. Wang An-Shih, a minister of the Sung dynasty who wrote Buddhist poems, tried to raise the condition of the farmers and undertook various economic experiments. Contrary to the Confucian tradition, he believed that the literati should also have specialized knowledge in ancient and modern laws and political economy. (Williamson, H. R. Wang An Shih, London: Arthur Probsthain 1935, vol. 2, p. 331).

There have also been numerous rebellions and secret organizations of Buddhist inspiration, such as the White Lotus and the Maitreya Society who had millenarian or chiliastic hopes and envisaged a new world order. Finally, there was the T'ai P'ing rebellion in the nineteenth century which built on these millenarian hopes but also borrowed from Protestant Christian ideas. Thus, Chinese Buddhism produced to a certain extent the «tension» in the form of millenarian and messianic ideas and of ethical prophecies which Weber denied to Confucianism. Building on these traditions modernization, at least in the form of socialism, could be introduced into China. 
Excursus: Japan

From China, Buddhism was introduced to Japan and encountered a nonBuddhist state cult (Shinto). Although Japan was a country of some interest even in Weber's time, he dealt with it only briefly, perhaps because he thought that Buddhism (and Confucianism) did not have a serious influence on the important aspects of the «spirit» of the Japanese conduct of life in the economic context, for the Japanese spirit, according to him, was in its main outlines not produced by religious factors but by the feudal character of the political and social structure (RI: 271). ${ }^{50}$ Japanese feudalism did not represent a complete feudal system and ended in the quasi-patrimonial regime of the Tokugawa: the granting of land to the daimyos resulted in an administrative office for them rather than in a fief in the Occidental sense (ES: 1075). Since the Tokugawa regime Buddhist monks belonged more and more to the non-literate strata. Only the Shin sect can be compared to Protestantism in the Occident, but, for the same reasons as Lutheranism, did not produce rational innerworldly asceticism.

The concept of the city as an autonomous seat of jurisdiction was absent in Japan - as it was in India and China (ES: 1227/8). The samurai, entitled to bear arms and to hold fiefs or rather military prebends, were personally free whereas merchants had no political rights. A people among whom a stratum of professional warriors played a decisive rôle could not attain a rational economic ethic on their own (RI: 275), but the feudal rela-

50 In an influential book Robert Bellah has tried to show that, on the contrary, Japanese religions - several Buddhist sects - and bushido, the moral code of the samurai, have furthered economic rationalisation by stressing diligence, frugality and, in general, the work ethic (R. Bellah Tokugawa Religion New York 1957/1985). These were functional equivalents of the Protestant ethic. This view has been questioned by a Japanese author (Maruyama Masao) on the basis that the magical elements of religion (particularly in Shinto) prevent a complete rationalisation. Another Japanese author (Morishima Michio Why has Japan succeeded? Western Technology and the Japanese Ethos. Cambridge 1982) was interested in the effects of Confucianism on East-Asian development, but he distinguished two kinds of Confucianism: Chinese Confucianism which expects loyalty to family and clan, and Japanese Confucianism, especially since the Meiji reforms, which stresses kokutai, loyalty to the state and to the tenno (emperor).

It should not be forgotten, though, that the religious or «inner» factors of the develpment of the capitalistic system, are, according ot Weber, insufficient for an explanation ; they must be seen in connection with the «exterior» factors, in particular the legal and political system. 
tionships based on contractual legal obligations offerred a basis for the development of an individualism in the Occidental sense. ${ }^{51}$ Therefore, as a result of the Meiji reforms, the administration of «fiefs» could be replaced by a bureaucratic administration, and Japan was easily able to take over capitalism as an artifact from the outside, although it had been unable to create it out of its own spirit.

\section{Later Indian Developments}

Turning back to India proper one notes that during the first millennium of our era Buddhism was pressed back and was finally almost completely eliminated. The princes strengthened their ties with the brahmanical intellectual strata and the caste organization. Hindu sects with an organized professional monkdom supported the slowly commencing restauration which was based on the non-literary plebeian strata. The Vedanta commentator Shankara initiated a monastic reform with the intention of fighting the heterodox Buddhist and Jainist monastic orders. Each monk and each lay person who belonged to a sect now had his guru (spiritual teacher). Thus, besides the caste order and its anchorage in the samsara and karma doctrine which the sects did not question, the veneration of gurus, almost living saviours, played and important rôle. Indian intellectuals up to this time had ignored the orgiastic, ecstatic and magical parts of popular religion, but now slowly an adaptation process took place: the cults of the old fertility gods Shiva and Vishnu were transformed according to orthodox ideas of vegetarianism and sexual abstinency.

Shivaism tried to free the old phallus (linga) cults of their sexual-orgiastic character and to create a ritualistic and ascetic temple cult. But the simple linga worshipper hardly knew Shiva and the meat and sexual orgies continued. Therefore, the insertion of the non-classical linga cult into the classical ritual was diffcult and the split between orgiastic and ascetic orientation continued. These latent difficulties were particulary evident in the Lingayat sect. The Lingayats rejected the caste order and had doubts with

51 According to Tu Wei-Ming, the Western concept of individualism (the lonely self) does not exist in Confucianism; rather, the self is a center of relationships («The Confucian Dimension in the East Asian Deveopment Model» in: Josef Kreiner, ed. The Impact of Traditional Thought in Present-Day Japan. Munich 1996, pp. 31-48). 
regard to the samsara dogma; they developed some rational and almost puritan characteristics, but they remained unbendingly ritualistic. The means of salvation of the intellectuals was meditation about the linga, the popular soteriology was magical and sacramental and obedience to a guru was stressed. For these reasons the rational characteristics of the Lingayats were unable to efface their traditional ritualism.

While Shivaism addressed itself to Brahmins as well as to peasants, Vishnuism found followers among the middle strata. It tempered and replaced orgiasticism by a passionate devotion to a saviour. Not sacred knowledge or ritual was at the forefront, but bhakti, the passionate godcentred devotion or belief in a redeemer and his grace. It was an inactive attitude of life, typical of pure belief-religiosity, including Lutheranism (RI: 384, n.36). ${ }^{52}$ The Vallabhacarins in particular, were a merchant and banker sect ${ }^{53}$ who did not seek salvation in the intellectual traditions of India, in asceticism or contemplation, but in refined sublimated orgies ${ }^{54}$ under the strong influence of gurus. The means and goals of salvation were graded and not ethically rational. It is evident in this sect, concludes Weber, that ascetic religiosity does not, as is often maintained, develop out of the inner nature of bourgeois capitalism - quite the contrary. Sects which considered innerworldly action as a path to salvation, nevertheless considered meditation as the higher path and disinterested action as superior.

52 Belief, according to Weber, is not an acknowledgement of facts or teachings, but the religious reliance, the faithful obedience and the orientation of one's whole life to a God or saviour (RI: 187). Weber also mentions Augustine, according to whom the assertion of intellectual propositions is the lowest level of faith (ES: 566). Weber thus uses the term in its older sense, as described by Wilfred Cantwell Smith in Faith and Belief (1979): In old English the word believe meant to be loyal and faithful. Shakespeare and Hobbes differentiated between belief and opinion. But since the nineteenth century the word to believe simply meant «to have an opinion» regardless whether the opinion was correct of false.

53 The term sect must be used with caution, as sects born from within the caste system are quite different from the Western notion of sect which Weber opposed to concept of church (vide Dumont, 1967, p. 349).

54 But vide: Jürgen Lütt «The Doctrine of the Vallabhacarya Sect and the Economic Performance of its Followers» International Sociology 2 (3) 1987 
One of the Vishnuit sects, the Kabir Panthi ${ }^{55}$, was strongly pacifistic, comparable to the Quakers, but their non-ascetic character and their obedience towards Gurus made an innerworldly autonomous conduct of life ot he occidental kind impossible.

But the dogma of the unchangeability of the world order remained common to all orthodox and heterodox Hindu thinking and it is quite evident that a community dominated by inner powers of this sort could not out of its own arrive at the spirit of capitalism. It was even relatively difficult to take over the economic and technically finished form as an $\operatorname{artifact}^{56}$ even if the Indian worker may be highly diligent. It never occurred to a Hindu to see in the success of his economic professional integrity a sign of his state of grace or to undertake the rational reconstruction of the world as a realization of God's will (RI: 326). The masses of the contemporary Hindus know nothing about salvation; they have this-worldly interests wealth and perhaps better rebirth chances. The religion of the intellectuals may have some indirect effects on their conduct of life, but not in the sense of innerworldly methodical rationality.

\section{A Retrospective View on the Asian Cultural World}

Asia was in principle the land of the free competition of religions and of tolerance ${ }^{57}$. There were both orthodox and heterodox religious forms. In

55 Kabir (1440-1518) was a mystic poet who combined Hindu bhakti and Islamic Sufism. Weber did not mention Sikhism, founded by one of Kabir's disciples, Guru Nanak. As the term Sikh, derived from a Sanskrit term for disciple, already suggests, the Sikhs had Gurus. They retained the Indian ideas of transmigration and karma, but at the same time they were monotheistic and forbade the representation of God in pictures. They practised commensality, at least «at the kitchen of the guru», and their caste structure was less rigid than among Hindus. At the beginning, their syncretic tendencies were encouraged by the tolerant Moghul ruler Akbar, but when persecutions set in under subsequent emperors, the brotherhood of Khalsa was founded: soldier-saints with a spartan code of conduct. It is this syncretism of Indian and Islamic ideas which may well have made a consistent innerworldly conduct of life difficult.

56 The English translation in RI: 325 regarding the take-over of capitalism in India is incorrect and misleading. Vide the German original in GARS II, p. 359

57 Critics of Weber's PE essay had pointed out that tolerance had a paramount rôle for the economic development of the Occident. Weber's mention of tolerance in Asia (India \& China) which had not in any way furthered a capitalistic develop- 
China, the upper social strata which rejected any kind of salvation religion stood against the folk soteriology of the masses; and at the same time the same relgion dispensed different forms of goods of salvation to different social strata. Everywhere in Asia one finds a gulf between the literarily educated and the non-literary masses. For the educated intellectuals of Asia literary knowledge and mystical gnosis were the absolute path to the highest good whereas the masses tended toward a saviour religiosity and indeed a hagiolatry of living saviours or gurus (RI: 335). This charismatic phenomenon was, beside the unbroken character of magic and the power of the sib, the main characteristic of the Asian social order. The world remained an «enchanted garden» (Zaubergarten), in which one revered or coerced the spirits.

While it is true that the circles of literary strata attempted to sublimate the orgiasticism and saviour belief of the masses - with limited success they only rarely succeeded in braking the grasp of magic. Not the rational miracle but magic remained at the centre of mass religiosity. ${ }^{58}$ This most highly anti-rational world of magic affected everyday economics, and there was no way to a rational inner-worldly conduct of life. Where the inner-worldly ethic was systematically specialized, as in the Indian caste ethic, it was simultaneously traditional and ritually stereotyped.

The unrestricted lust for gain, the «acquisitive drive» of tradesmen and artisans in Asia is probably unequalled in the rest of the world. Capitalism existed among all Asian religions, but not modern capitalism and not the capitalist spirit, for Asian religions were lacking in precisely that which was decisive for the economics of the Occident: the temperance of this lust for gain and its immersion into a system of a rational innerworldly ethic as produced by Occidental Protestantism (RI: 337), thus creating the religious motivation for seeking salvation through immersion in one's

ment, is an implicit rejection of his critics. Tolerance, he wrote, may be able to populate a country and to import foreign professionals, but Weber is rather interested in the question who might benefit from the tolerance. Only if Jews or ascetic Christian denominations benefitted from it, the result was the spread of the spirit of capitalism (AC: $66 \& 100)$

58 The «miracle» implies, according to Weber, a kind of belief in a rational guidance of the world or in a divine gift of grace and is therefore more innerly motivated than «magic» which is bereft of all meaning, is irrational and produced by pure arbitrariness (RI: 335/6). The English translation regarding the distinction between miracle and magic in RI: 335 is garbled and meaningless. Please see the German original in GARS II: 370 . 
worldly vocation. On the level of the privileged strata in Asia the patterns of life showed feudal characteristics in Japan, were patrimonial-buraucratic in China, and were a mixture of knightly, patrimonial and intellectualistic traits in India, whereas in the Occident the creation of a rational innerworldly ethic was bound up with the appearance if thinkers and prophets who lived in a social context which was foreign to Asian culture: the political burghers of the city without whom neither Judaism nor the development of Christianity are conceivable (RI: 338). The inner order of the real world remained concealed to the high-ranking intellectuals of Asia because it was of no interest to them. Their life was oriented to the imitation of exemplary prophets. To the plebeian strata, on the other hand, no ethical prophecy appeared to rationally form their conduct of life.

\section{Ancient Judaism}

\section{Basic Literature}

Max Weber, Ancient Judaism New York: The Free Press 1952

Max Weber, Gesammelte Aufsätze zur Religionssoziologie III Tübingen: Mohr Siebeck 1920

Wolfgang Schluchter, Rationalism, Religion, and Domination, University of California Press 1989 Chapter V: Ancient Judaism: Origins of World Mastery, pp 163-204)

Wolfgang Schluchter, Max Webers Studie über das antike Judentum Frankfurt a.M.: Suhrkamp 1981

Max Weber's essays on the economic ethics of world religions may be considered as analyses of an epoch of world history which the German philosopher Karl Jaspers later called the axial time ${ }^{59}$. Approximately between the years $800 \mathrm{BC}$ and $300 \mathrm{BC}$ there lived in China Confucius and Lao tse, in India the Buddha and in Persia Zoroaster, in Greece there lived Socrates and Plato, and prophets like Jeremiah and Isaiah appeared in Palastine. Weber's essays may be read as the result of an effort to describe the world images which were formed during the axial time and which de-

59 Karl Jaspers, Vom Ursprung und Ziel der Geschichte München: Piper 1949. Instead of using the concept of axial time, more recent scholars often talk of axial civilizations and include Akhenaton (vide Jan Assmann, 1992, p. 290) and Mohammed in the line of religious founders who initiated an axiological turn and systematised practical action to a conduct of life, thus producing a personality. 
termined the tracks along which the great cultural traditions were pushed forward by the dynamic of interests. In this way Weber thought to be able to seize the specificity of the Occidental evolution.

In this context Weber attributes a crucial position to ancient Judaism. Because of its rational religious ethic of innerworldly action, free of magic, it was worlds apart from the paths of salvation offered by Asian religions; at the same time it was a crucial contributor of Western development. Only hellenic intellectual culture, Roman law, the Catholic Church resting on the Roman concept of office, and Protestantism equal ancient Judaism, according to Weber (AJ: 5), in world-historical significance. But Weber then asks why, in spite of all, Judaism nevertheless did not contribute to the development of the modern capitalistic mentality.

Weber's analysis comprises the time of the confederacy of peasants and herdsmen before the year $1000 \mathrm{BC}$, the time of kingship of the city-based culture until the conquest of Jerusalem by Nebuchadnezzar (597/587 BC), the consequences of the Babylonian exile for the development of the religion, and some hints about the time of the hierocracy after the return from Babylon. In general, Weber discovers a great independence of intellectual culture in ancient Israel, and he observes that rarely entirely new religious conceptions have originated in the respective centers of rational cultures, not in Babylon, Rome, or London, but in Jerusalem, in the late Roman province of Africa, in Geneva or in New England. For humans who are distant from the great culture centers have not yet unlearned how to face the course of the world with questions of their own (AJ: 206).

The Transcendent God, the berith, and the Prophets

Israel's god was a god of heaven, just as originally in China. But while China became a pacified world empire and its heavenly god an impersonal and order-forming power, Israel remained a politically endangered small state and Jahweh a transcendent personal creator and war god, conceived as a partner of a covenant (berith) between himself and the Israelitic tribes, a god of political events, a superhuman and yet comprehensible personal master whom one must obey and whose positive commandments are to be followed. The supporters of Yahweh opposed the sexual-orgiastic character of the Baal-cults and the kind of religiosity influenced by them; they also opposed any kind of magic as it was considerd impossible to coerce Yahweh by magic. The representatives of this turn against orgiasticism 
and magic were mainly levitic priests, bearers of the knowledge of Yahweh's commandments, to be found in the Thora, mainly in Exodus 20, 2-17 and Deuteronomium 5, 6-18.

Weber sees the difference between magic and religion tentatively in the fact that magic contains bans in the form of tabus, but no duties and no law, that it delivers oracles and concrete maxims of wisdom, but no sermon and no rational law and coherent register of commandments like the decalogue. While elsewhere one may find magic spells, in Israel one finds miracles, for the miracle is, as opposed to magic spells, a more rational construct, sprung from meaningful, understandable intentions of the godhead. According to Weber, Israel was not an irrational magic garden like India, but it was penetrated by the idea of a fundamentally understandable god who directs the fate of his people, and by the idea of a rational providence (AJ: 223). And while for instance in Egypt there were magical substitutes for the fulfillment of the commandments (for the use of a scarabaeus allowed the dead to hide their sins before the judge of the dead), in Israel this kind of magic was absent and the ethical commandments had greater practical impact. Their relatively extensive rational systematization was the product of the work of the Levitic priests.

Moreover, all promises of Yahweh were tied to the good behaviour of the people who as an association of free compatriots were jointly responsible for keeping the commandments of the god of the convenant; all had to fear the vengeance of God if they tolerated a violation of God's commandments in their midst.

In this constellation there appeared the phenomenon of prophecy, a kind of demagogy to a certain extent, which would have been impossible without the precarious situation of Israel in the world-political situation between Egypt and Babylon. The question which these prophets/demagogues asked was not as in Athens: how does one become a good citizen, but rather: how does one fulfill Yahweh's commandments. For the obedience to these commandments was the special duty of Israel because of the berith. In the mind of the prophets Yahweh was the god of the political union, an acting god, not the god of an eternal order. Moreover, since the prophet Amos he was not only the originator of all possible good, but also of doom.

Prophets never claimed the right to be worshipped in the manner of hagiolatry. And when they were «seized» by the spirit of Yahweh, this was not the tranquil euphoria or mystic union of the god-possessed, as in India, but a stormy demand. Their concept of God directed the interpretation 
which the Jewish prophets gave to their ecstatic experiences and determined the selection of such psychic states which might qualify as truly prophetic (AJ: 313). Because of this a priori of the Jewish concept of god the prophets could not be mystics. Their god was understandable by man and he was a ruler of whom one desired to know how to obtain his grace.

The prophets never raised the question of the «meaning» of the world and especially of life. Yahweh's being and his decisions contained nothing beyond understanding, and even world events were considered by the prophets to be rational in character. There was much economy of psychic resources in the fact that all rumination about the meaning of the cosmos was precluded and that only conduct according to the commandments of God behoved man (AJ:317). Essential for the prophets was the central religious mentality, the faith in Yahweh's omnipotence. Obedience and humility were the ensuing virtues, an abject submission to God's counsels which would have been shocking to the Greek hero's sense of dignity and which, according to Weber, can develop only in the neighbourhood of world monarchies.

\section{Pariah People, Pariah Ethics, and Pariah Capitalism}

Why did this mentality not lead to innerworldly action on the basis of an ethic of conviction and to a modern bougeois conduct of life? Weber provides two connected reasons. The first reason can be found in the fact that the Jews, living either in the neighbourhood of or within large monarchies, became a pariah people ${ }^{60}$, a guest people who were ritually separated, formally or de facto, from their social surroundings (food restrictions and the interdiction of the connubium with outsiders). This ritual separation of the Jewish community had its beginnings during the Babylonian exile and was

60 A lively discussion has taken place about Weber's thesis that the Jews lived in a voluntary ghetto as a pariah people, a thesis which Weber derived from a comparison with India's outcastes. Critics have advanced the argument that the Jews expected a complete upheaval of the social organization of the world - contrary to the situation in India where the caste system was considered as permanent and unchanging. Whatever one may think of the well-foundedness of this concept, it serves Weber to describe a background against which he characterizes the Pauline mission as liberating the Christians from the ritual segregation which was at the root of the Jewish pariah position. Vide ES: 622 and also W. Schluchter, Handlung, Ordnung und Kultur Tübingen: Mohr (Siebeck) 2005, p. 55 
further developed after the return from exile by the priestly hierocracy under the Persian protectorate: prohibition against mixed marriages, commensality, observance of the Sabbath. It was mostly self-imposed, but the term pariah also seems to refer to the politically and legally precarious situation of the Jews as a guest people within their non-Jewish environment.

But why did an increasingly bourgeois community - for the observance of the ritual was made extremely difficult for the peasants - voluntarily adopt a pariah-situation? The answer can be found in the prediction of the prophets, namely that the social order of the world will be turned upside down by Yahweh and that a glorious future awaits those who patiently endure in their pariah-situation. These were political predictions about the future of this world. Deutero-Isaiah in particular (Isaiah 40-55) has produced, on the basis of the pariah situation in Babylon, the only serious theodicy of ancient Judaism, an apotheosis of suffering, misery and humiliation and the patient enduring in it, a plebeian view according to which only the wretched, the poor and the powerless are good. ${ }^{61}$ The situation of the pariah people was here elevated to the highest station of religious worth and honour before God. In this way the religious Jew proved himself; his piousness showed itself in the endurance of his pariah situation, not in rational domination of the world, and not in rational economic activity.

The second reason was found by Weber in what he called a pariah ethic. With regard to the legends of the patriarchs (which, however, were written down much later) Weber refers to this pariah ethic (AJ: 50), a certain pacifism and lack of heroism and a rather questionable commercial ethic (a play to outwit each other goes on between Jacob and his father-inlaw); as well as the passing off of their beautiful wives as desirable sisters and surrendering them to their prospective protectors - Gen. 12.13; Gen. 20.2; Gen. 26.7. Moreover and more in relation to economic activity, the separation of economic in-group and out-group morality was decisive for the religious evaluation of commercial activity. The dualism of the economic ethic precluded the possibility that, as in Puritanism, rational economic activity was ever seen in a positive religious light, for if a form of behaviour, e.g. interest taking, was strictly forbidden towards brothers in belief, but was considered as an adiaphoron (neither good nor bad) in rela-

61 Weber was probably inspired by Nietzsche's Antichrist, a critique of Christianity in which Nietzsche described a mutation of all values in the sense of an overthrow of aristocratic values and a religion based on the resentment of the masses. 
tion to outsiders, the possibility of proving oneself religiously through innerworldly asceticism became unavailable. ${ }^{62}$ In contrast to this attitude the Baptists and Quakers had pointed with pride to the fact that precisely in economic relationships with the godless they had substituted legality, honesty and fairness for falseness and unreliability. In the Jewish economic ethic, however, there was no soteriological motive whatever for ethically rationalizing out-group economic relations. Even the (traditionalistic) high esteem for religiously pursuing one's daily work by Jesus Sirach could not alter this fact. Economic activity could not become, as in Puritanism, an area of ethical and religious proof.

On the whole, as Weber wrote, the legally and factually precarious position of the Jews hardly permitted continuous, sytematic and rationalized industrial enterprise with fixed capital (ES: 614), and the pariah ethic implied a non-rational economic attitude. No trace can be found of an appreciation of economic activity as a virtue (AJ: 254); the area of proving one's piety lay in a quite different region from that of rationally mastering the world or the economy. The pariah capitalism which resulted from this situation consisted of state provisioning, trade, and money lending, but not of industrial production or manufacturing. And although pious Jews did not reject colonial capitalism, tax farming or political capitalism, as Weber pointed out, the East European regions where Jews had been at home for a long time, failed to develop specific traits of modern capitalism (AJ: 345).

Weber's Judaism thesis contains an inner tension: on the one hand, the Jewish conception of a transcendent and acting God conducted to innerworldly action, based on an ethic of conviction; on the other hand, the religious prophecies and the paths of salvation connected to them tended to stress the obligation to endure in the given situation. In this can be seen the Janus-like position which Weber attributes to Judaism within the history of the Occident. The Jewish conduct of life was an important historical precondition of the spirit of capitalism, but it did not contain the possibili-

62 With regard to the dual ethic, Freddy Raphel in «Max Weber and Ancient Judaism» (Leo Baeck Institute Yearbook 18.1, 1973) has pointed out that at least Joseph Caro's code (sixteenth century), an authority on Jewish tradition, formally forbid the exploitation of Gentiles by usury and that at least in some cases strict legality was required towards outsiders while supplementary solidarity was expected towards one's own people. 
ty to demonstrate one's ethical merit by means of modern business activity (ES: 616). ${ }^{63}$

\section{Supplement: The Pharisees}

Since Maccabean times a significant change took place which left a definitive imprint on Judaism. The motive for the rise of the movement of the Hasidim and then mainly of the Pharisees was a reaction against Hellenism. The Pharisees gave their movement the form of an order or of a «brotherhood» whose members lived in the most rigid Levitical purity. The charisma of the hereditary priests was devalued in favour of personal religious qualifications based on conduct and education.

It was decisive that the Pharisees segregated themselves not only from the Hellenes but also from the less ritually observant Jews, the «countrypeople» with whom they avoided connubium and commensality. We are faced here with an inter-local sect of like-minded persons. The rise of the Jewish diaspora since Maccabean times and the unshakability of its communities was the work of this brotherhood. The community of the «chaber», and not any more the hereditary charisma of the priests now became the bearer of the religion.

The Pharisees created the synagoge, the central institution of late Judaism which for the Diaspora Jew replaced the priestly cult in the Temple of Jerusalem, and they introduced instruction in the religious law which became foundational for Judaism. Above all, one now consulted the teach-

63 As W. Schluchter (2005: 83) has suggested, this passage in the section on the sociology of religion in ES was Weber's response to W. Sombart's thesis in Der Bourgeois (1913) that Judaism equals Puritanism in its effect on the spirit of modern capitalism. According to Weber, Judaism and Puritanism (and worldly wisdom teachings of philosophers, economists and others) have different potentials of efficiency. For pious Jews many economic transactions were at best permissible on the basis of a lax interpretations of their religious code, or they might be ethically indifferent so that success might be a sign that one had done nothing objectionable or that one had acted appropriately in non-economic contexts. The pious Puritan, however, could demonstrate his religious merit precisely in his economic activity, based on absolutely reliable business practices (ibid.). «Not the doctrinal teachings in general develop a life-changing force, but religious beliefs which are able to set sanctions of a non-economic character on the fulfillment of a particular conduct of life.» (PE: 145 - footnote). 
er learned in the law rather than the priest if one was in external or inner difficulty or doubt.

Philosophical speculation was rejected as Hellenistic and practical rationalism or common sense, characteristic of petty bourgeois strata and their economic interests, was favoured. There was also, for practical reasons, some accommodation to the prevailing mass beliefs of plebeian strata, for instance to the messianic hope in the resurrection of the dead which the high-ranking Sadducees (priestly sibs) absolutely repudiated.

The final dominance of the Pharisees began with the second fall of the Temple: then all Judaism became Pharisaic. This was also the time of the rise to dominance of the rabbis.

The rabbis were not at the begginning an exclusive organization: people simply consulted those who legitimized themselves through charismatic knowledge of the law. They were plebeian intellectuals who gave advice and counsel while also holding down a secular occupation (vide the Pauline «if any would not work, neither should he eat»), for there was a rigid prohibition against teaching the law for compensation. The rabbis were no magicians ${ }^{64}$ or mystagogues (as their Indian counterparts); their activity and influence was based on teaching and writing only. With the idea of charismatic prophecy 65 the learned rabbis lived in a state of tension, as is characteristic of any scripturally learned men who are ritualistically oriented to a law book. Finally, they were no bearers of an esoteric salvation doctrine, a gnosis, for any gnostic pusuit of salvation devalues the law and the ritualistically and ethically correct conduct. The Jewish rabbi dispensed neither sacramental grace, nor was he a charismatic helper in need. His special religious gift was knowledge. His personal authority rested in serving as a model by leading an exemplary life. He taught the law and he gave responsa in the manner of the Roman jurists.

There were expectations of a Messiah for the Jewish people and they imparted a tremendous pathos to the piety of the Jews (the difference from

64 Magic had no place in post-prophetic Israel; the idea that one may coerce a transcendent God through magic was completely eliminated. But, according to Weber, magic continued to exist in two forms: exorcism and healing. In these particular cases not the coercion of God but of demons was involved. In any case, these activities did not belong to the normal activities of the rabbis.

65 The teaching of the closure of the prophetic age led to the assumption that the holy spirit had vanished from the world and that all that remains is the spirit required for the correct interpretation of the sacred law. 
all Indian cyclic saviour religions rests precisely in the presence of such expectations of a last day), but for the individual Jew only the law and its fulfillment came into consideration. But «world rejection» or world devaluation followed in no way.

Pharisaic Judaism was also far from rejecting wealth or from thinking that its enjoyment endangers salvation although the unbrotherly exploitation of economic power as shattering the old neighborhood ethic was condemned. Stipulations against usury and in favour of debtors and slaves were casuistically elaborated. But any point of departure for an economically oriented methodic of innerworldly asceticism was lacking. The dominant attitude of the Talmud thus differs greatly from the Ebionic ${ }^{66}$ hatred of wealth in the Gospel of Luke (AJ: 403).

The Pharisees did not demand a separation from economic and innerworldly life, but this was not the case of Essenism, a Pharisaic sect. They segregated themselves from the less pure not only by excluding connubium and commensality but all contact (AJ: 406). The fear of ritualistic defilement was extremely intensified, secular enjoyments were considered objectionable and copulation was restricted to Wednesdays. The commandment not to steal was intensified to the effect that no economic gain was permissible. They therefore shunned trade and the possession of money. They preached to «love one's enemy» and they lived by a disciplina arcani ${ }^{67}$. The motive for the way of life of the Essenes can probably be found in their secret teaching, consisting apparently of an allegorical reinterpretation of Jewish holy books. With regard to rituals, the rejection of the animal sacrifice was characteristic.

The organization and religious conduct of the Essenes have often been compared to original Christian practice: they knew the baptism, the lovemeal (agape), the support of the poor, they had a strongly pacifistic ethic and they estimated the hopes for salvation of the poor higher than the hopes for the rich. 68

66 The Ebionites were a Jewish-Christian sect which stressed poverty and common property.

67 The obligation to keep one's doctrine secret from outsiders. Disciplina arcani was also practiced by Shiite Muslim sects (e.g. the Druzes in case of danger) and some Russian sects.

68 By centering on the Essenes rather than on the Sadducees, Weber seems interested in the influence of rabbinic-talmudic Judaism on later Jewish developments in the Middle Ages and on its closeness to ancient Christianity (vide: E. Otto in his «Einleitung» to MWG I / 21-1, p. 140). 
The Pharisaic purity ritualism resulted in higher ritual barriers against both outsiders and other Jews (AJ: 415). The Essenes segregated themselves by avoiding connubium and commensality and all contacts with other Jews, the Pharisaic brotherhood segregated itself from the «country people», those influenced by the Jerusalem priesthood segregated themselves from the Samaritans. Thus, there emerged a caste-like structure of the old Yahweh believers whereas towards the outside world Jewry increasingly assumed the type of a ritualistically segregated guest people, a pariah situation which was voluntarily created and not one suffered under the pressure of external rejection. While antisemitism did indeed exist, it was the negative attitude of the Jews themselves - the refusal of the connubium, of commensality and of any sort of fraternization even in business life - which was decisive for the mutual relations with the outside world.

\section{Islam}

\section{Basic Literature:}

Toby E. Huff \& Wolfgang Schluchter (eds), Max Weber and Islam New Brunswick \& London: Transaction Publishers 1999

Wolfgang Schluchter, Max Webers Sicht des Islams Frankfurt a.M.: Suhrkamp 1987 Max Weber, Economy and Society University of California Press 1978

Max Weber never published an essay on Islam. But it is possible, by drawing together his comments on it in his Economy and Society, particularly in the chapters on the sociology of law, of domination and of religion, to arrive at a relatively clear outline of what he might have written on the economic ethics of Islam, at least with regard to early Islam. W. Schluchter has tried this and this chapter has been inspired by his effort.

The structure of Weber's analysis would certainly have been similar to that which he employed in all other cases: it would have been divided into two parts, the institutional factors (also called by him the exterior form) and the motivational factors (the interior spirit). With regard to the Occident Weber made this distinction between institutional and motivational factors when he said that there are political and legal as well as attitudinal presuppositions for the development of modern capitalism, or, in his words, «only the Occident knows the state in the modern sense ..., only the Occident knows rational law, made by jurists and rationally applied, 
and only in the Occident is found the concept of citizen, because only in the Occident does the city exist in the specific sense of the word... Finally, Western civilization is distinguished from every other by a rational ethos for the conduct of life» (GEH: 313).

\section{Islamic Patrimonial Domination}

Islam was the latest product of Near Eastern monotheism after Judaism and Christianity, the other two «religions of the book». At the very beginning it may have developed in pietistic urban conventicles, but it then rapidly transformed itself into a warrior religion with a strong status emphasis, a religion of masters, as Weber wrote (ES: 624).

As opposed to the Jewish prophets and to Jesus, Mohammed was a religious and a political leader, he was not just a proclaimer of Truth, but also the rightful ruler. In Mecca and Medina he established the umma (the religious and political community) in place of the rule of Arabic families and tribes. As in all cases of charismatic leadership, the question of succession posed a problem, and the history of Islam was decisively influenced, as Weber notes, by the fact that one branch, the Shia, recognized the hereditary charisma of Ali's (Mohammed's cousin and son-in-law) family and descendents, while the other branch, the Sunna, was based on tradition and ijma (consensus). The astonishing thrust of the new Islamic movement which within a few dozen years spread from the Arabian peninsula and was able to conquer large parts of the Middle East and North Africa, and later India and beyond, may be related to the connection of religion and politics: there were ideal and material interests which resulted in the «elevation of the believers through the subjugation of the unbelievers to their political authority and economic domination» (ES: 474). But not only the conversion of unbelievers was at stake, writes Weber; the primary purpose was revenue or the payment of tribute by the members of other religions.

Non-believers not only were conquered, they also had to be administered, and soon, under the Abassids (750 - 1258), the caliphate separated from the sultanate, dividing spiritual and worldly tasks, but both subject to the same religious law (sharia). A caesaro-papist solution was never at- 
tempted, but in Shiite Islam short-term theocratic solutions have sometimes appeared. 69

Weber characterizes the kind of patrimonial domination in traditional Islamic countries as sultanism and prebendal feudalism. Contrary to Western medieval fief-based feudalism which was at least an approximation of a rule based on law (ES: 1082) and in which the feudal relation resulted from an exchange of a beneficium (fief) and a homagium (the promise of loyalty, particularly in war) by way of a free contract, leading to a conduct of life based on fealty and honour as opposed to filial piety, one finds in Islamic states armies of purchased slaves (Janissaries) and military fiscal prebendalism. This was so, with some modifications, not only during the Abassid, but also during the Mamluk and Ottoman dynasties.

Weber writes that already the Abassids bought militarily trained Turkish slaves who were totally tied to the ruler's domination (ES: 1015). By creating an elite troop of purchased slaves, the central power now had at its disposal an instrument that freed it from dependency of the quarreling Arab tribes. Prebendal fiscal feudalism then developed when slave generals began to function as tax collectors and then as tax farmers in specific areas. A consequence was the legal insecurity of the tax paying population in face of the arbitrariness of the troops, and this, in turn, particularly since the period of the Seljuks, paralyzed commerce (ES: 1016).

The two institutions, the military slave system and the military (tax farming) prebends increased the possibility of arbitrary discretion and lessened the calculability of the administrative/legal processes. One of the consequences, according to Weber (ES 1096), was an artificial immobilization of wealth by means of religious foundations (waqfs) in order to evade its arbitrary seizure. In a more general way Weber claimed that the patrimonial state lacks the political and procedural predictability and the trustworthiness and objectivity of the legal order which is indispensible for capitalist development as it is provided by modern bureaucratic administration (ES: 1095).

69 In the Shia tradition, as for instance in Persia, an entrusted imam (a qualified theologian who replaced the hidden imam, a descendent of Ali) was to uphold Allah's command as the true interpreter of the Koran. In times of crisis there was the hope that a Mahdi, a messianic deliverer, will fill the earth with justice and equity. Weber called such messianic or chiliastic hopes which scorn every thought of a rational order in the world, irrational (ES: 550). 
The second point of comparison was that between the medieval Northern European city and the oriental city. Weber asked why the oriental city tends to obstruct rather than favour the development of rational capitalism although it also had merchant and artisan guilds with autonomous statutes.

Weber distinguished cities according to which stratum rules in them (patrician or rentier city versus plebeian or producer city) and also with regard to the question of whether they have political, administrative, military and legal autonomy and autocephaly, legitimated only by the principle of the corporate urban commune. The city as an autonomous corporate commune in which the fraternity of the burghers stood above the solidarity of tribes and guilds existed only in the Occident while in the Islamic world the prerogatives of patrimonial rule were never broken and the traditional statusses of lord and subject were never replaced with membership status in the city commune.

Mecca, for instance, was a kind of clan city (ES: 1231), with divisions according to tribes and clans as the basis of military organization. Although the city was a location of powerful economic interests, it was not a communal organization. The umma, the religious community, was too weak to cause a break with tribal and clan bonds because the legal institution which might have been able to do this, the concept of the corporation, was lacking. The central organization of military prebendalism prevented it.

As neither the city nor the church developed as independent corporate bodies in the Orient, there were no counterforces to challenge Islamic patrimonialism; the heterogeneity or structural pluralism of the West was lacking and thus one of the prerequisites for the development of rational industrial capitalism.

Finally Weber pointed out that in the Occident, in contrast to Islamic countries, a technically and juristically schooled administration was available because of a clear dualism of sacred and secular law and because these laws were able to develop according to their own inner logic (ES: 828). Why could trained specialists at a culturally dominant level only be found in the West? Weber provided two reasons. On the one hand, the development of secular law was able to take the Roman and Germanic legal traditions as guides and was closely connected to the development of the medieval occidental city and, on the other hand, the West had organs of rational sacred law making in the Church Councils and the papal powers of jurisdiction. 
Islamic law (sharia) is sacred law, the product of four major law schools (ES: 820); it was developed by theological jurists (mufti) who must be distinguished from judges (qadi) whose decisions were often based on personal discretion. Since the so-called closing of the gates of ijtihad (the accepted view - since the tenth century - that independent interpretation of the law is no longer necessary nor advisable) it was stereotyped and opposed secularization (ES: 820). On the other hand, as religious rules were not comprehensive, there were certain administrative institutions governed by human profane law although this law was considered to be of an inferior kind.

Islamic sacred law also was an impediment to the establishment of a unified legal system because its realm of validity was limited to Muslims (ES: 821) while the particular laws of the subjugated people continued to exist. Originally the Shiites, perhaps under Zoroastrian influence in Persia, even tried to prohibit as unclean all economic intercourse with unbelievers who followed different laws, but various legal fictions prevented this outcome. The dominance of sacred law was, moreover, a decisive impediment to the establishment of a predictable legal procedure, for it did not allow for a formal juridical systematization. Neither the spiritual nor the the worldly jurisdiction developed an abstract logic in legal thinking, both were oriented toward concrete and law-transcendent fairness and appropriateness (ES: 823). The reason for this can be found in the fact that legal interpretation of sacred law became stereotyped since the introduction of the theory of the closing of the gates of ijtihad in the tenth century and that profane law was dominated by sacred law and the gulf between sacred and profane law could be overcome only by circumventing strategies and doubtful casuistry, i.e. in an opportunistic manner (ES: 821/2). Therefore, in typological terms, Islamic justice was for Weber a theocratic qadi-justice (ES: 1116) because of its spirit of material justice based on extra-legal postulates which prevented a logical systematization of law in terms of formal juridical concepts and procedures.

Patrimonial governments lack the political and procedural predictability which is indispensible to capitalist development (ES: 1095), and it is therefore not surprising that capitalistic industrialization was impeded by 
the religiously determined structure of the Islamic empires, their officialdom and their particular kind of jurisprudence. ${ }^{70}$

\section{The «Spirit» of Islam}

Weber's view of the «spirit» of Islam can best be approached if one starts from the observation that there are a number of aspects in which Islam and Calvinistic Protestantism are not different. In both of them there is one transcendent God who is omnipotent and omniscient and the gulf between this God and human beings is unbridgeable. Moeover, in both religions the rôle of mediators between God and humans is significantly reduced: Mohammed was simply an ethical prophet and the Jesus of the Calvinists died only for those whom God had chosen. The idea of a church as an institution of grace and salvation is foreign to both religions.

But these are external aspects which did not prevent two very different outcomes: the spirit of traditionalism in Islam and the spirit of rational capitalism in the West. These diffenrent outcomes are largely related to the idea of proof of being chosen by God in Calvinism and to the interpretation of providence.

In Islam, original sin and the idea that human beings are incapable of being good is absent. Moreover, while Calvinism demanded of its believers not single good works but a systematic conduct of work and life in or-

70 Interesting is the description of the Mughal goverment as patrimonial-bureaucratic, based on the A'in-i Akbari (Regulations of Akbar by Abu al-Fazl) and the remarkable congruence between these regulations and Max Weber's ideal type of patrimonial-bureaucratic domination. Vide: Stephen Blake «The Patrimonial-Bureaucratic Empire of the Mughals» in: Journal of Asian Studies 39, no. 1 (1979), pp 77-94. In these regulations the emperor Akbar (1542-1605) is depicted as a «perfect man», a Sufi phrase which describes a person who enjoys a special and intimate relationship with God (more on Sufism below), the emperor's household as the central element of government, members of the army as reporting directly to the emperor, the administration as a loosely sructured group of men controlled by the imperial household, and travel as a significant part of the emperor's activities. There were no clear-cut lines of authority, officials (who often received prebends) were rotated from post to post and were not allowed to specialize in either civil or military matters (the mansabdari system). The urban organization (capital cities, provincial headquarters) revolved around the resources and requirements of imperial and noble households which dominated not only political but also economic activity as the central institutions of production, exchange, and consumption. 
der to prove that one is chosen by God, in Islam no one is considered incapable of being good or of fulfilling Allah's commandments, and the final judgement functions according to the principles of bookkeeping. The fulfillment of one's duty is the real foundation of salvation (the five pillars: repetition of the creed, prayer, almsgiving, the fast during Ramadan, and pilgrimage) and not, as in Calvinism, a mere indication of grace. Allah guides those who show themselves open to his revelations and follow his positive commands. Therefore, the ethical concept of salvation is really alien to Islam so that Islam cannot be considered as a religion of salvation (ES: 625). The original bearers of the religion, people of knightly status, had no sense for concepts such as sin, humility and redemption (ES: 472).

This leads to Weber's comments on the concept of providence in Islam. It knew nothing of Calvin's «double decree» and did not attribute to Allah the predestination of some people to hell and of others to everlasting life (ES: 574). Not original sin and saving grace for those who are chosen, but offence and just punishment are the focus of thought. One's fate in the beyond is secured by observing the five pillars of Islamic faith, and Allah guides the faithful who are in distress; it is not linked to the idea of proof. Rather, in Islam providence is related to one's fate not in the world beyond, but in this world; it is predetermination, as Weber writes (PE 227, $\mathrm{n}$. 36) rather than predestination. The Islamic doctrine of providence is thus not developed as consistently and coherently as its Calvinistic counterpart, for it simply juxtaposes two lines of thought: the absolute power of Allah and the self-determination and responsibility of man.

Therefore, the most important thing in Calvinism, the search of the believer for proof of his election, played no part in Islam. Only the fearlessness of the warrior could result because the time of his death was predetermined and needed not worry him, but not any rationalization of life as there was no religious reward for it. The Islamic doctrine thus leads to fearlessness in battle and war (ES: 574/5), but daily life remained unsystematic, utilitarian and and even fatalistic (kismet); in extraordinary situations it unifies and disciplines, in everyday life, however, it loses its influence. 
The economic ethic was feudal ${ }^{71}$, and the most pious enriched themselves by military booty. The rôle played by wealth was diametrically opposed to that played in Puritanism. Muslims took pleasure in luxury (luxurious raiments, perfume etc.). Weber quotes the traditional saying that when God blesses a man with property, he likes to see the signs thereof visible upon him (ES: 624). The Koran rejects every kind of monasticism, though not all ascetism (e.g. fasting). Avoidance of certain unclean foods, of wine, and of gambling is required - which had consequences for speculative business.

\section{Sufism and Conclusion}

Since the $12^{\text {th }}$ century, Sufism with its orders of dervishes, originally from Persian and Indian sources, penetrated the petty-bourgeois strata almost

71 Bryan Turner (Weber and Islam, London: Routledge \& Kegan Paul 1974) wrote that Islam was an urban religion of merchants and state officials, and that many of its key concepts reflect the urban life of a mercantile society in opposition to the values of the desert and of the warrior. When Weber attempted to show that Islam was a religion of warriors and produced an ethic which is incompatible with the spirit of capitalism, he was, according to Turner, hopelessly incorrect (ibid. p. 2). Islam may well have experienced a permanent division between the ruling institutions (sultanate, military, legal experts), the merchants, and the tribal desert dwellers, each group with its own ethic ; Ibn Khaldun may then have been correct when he described how beduin tribesmen with their tribal loyalty (asabiyya) from time to time plundered and took control of the cities where such asabiyya did not exist, and how they then acquired the culture of the cities and watered down their loyalty and group feeling.

But Turner's reference to an article by Goitein in the Journal of World History («The Rise of the Near-Eastern Bourgeoisie in Early Islamic Times», vol 3, (1957), pp. 583-604), with comments on Muhammad Shaibani's On Earning hardly supports Turner's argument. Shaibani (died 804) tried to show that striving for a decent living and even for luxuries was not opposed by Islam but regarded as permissible, lawful, and even desirable. But the arguments advanced are ambivalent. There are sayings extolling poverty and sentences in canonical collections urging man to strive for a prosperous living. There seem to have been no social prejudices against business, although it was natural, according to Goitein, that the honoured and more lucrative posts in the administration and army attracted the more enterprising brains. In any case, the striving for and showing of luxuries was not part of the Protestant ethic, nor can the permission or the advice to acquire wealth in any way be compared with the psychological sanctions which Protestantism set on diligent work. 
everywhere $^{72}$, from Tunisia to Indonesia, but it was even further from developing innerworldly ascetism as it followed orgiastic, pneumatic and mystical paths and was essentially irrational and otherworldly (FMW: 269 \& ES: 626). The Sufis conceded the legitimacy of the sharia and of kalam (rational theology), but they also claimed intuitive insight which can be expressed for instance in poetry (e.g. Rumi). Although the principles of Islam do not recognize an intermediary between Allah and the individual believer, the Sufi orders expected absolute devotion to their respective pir (leader). They also required poverty, although often in a metaphorical sense, namely poverty as non-attachment. Both irrational Sufism and the official traditionalistic ethic directed the conduct of life of Muslims into paths whose effect was opposite to the methodical control of life found among Puritans in the Occident (ES: 626). There were also diversions from any methodical control of life by the advent of cults of local saints and by magic, tolerated by the consensus of the community.

On the whole, Islam did provide the motivation of a status group of warriors for world conquest and for innerworldly action, but its economic mentality, particularly to the extent that merchant strata later moved to the forefront, was traditional and world-adjusted. As a warrior religion it was tied to the concept of holy war (jihad) and to the division of the world into the house of Islam and the house of war (dar al-Islam, dar al-Harb), but Islam lacked, according to Weber, all promises of a messianic realm (ES: $626)^{73}$, at least to the extent in which they were linked with meticulous fidelity to the law, as in Judaism. More importantly, Islam did not provide a force to transform the conduct of life from within because it lacked the Calvinistic idea of proof. The ideal personality type of this religion was not the literatus (as in China), nor the ritualistic priest (as in Hinduism), nor the wandering monk (as in Buddhism), but the world conquering warrior.

72 An exception may have been the Mevlevi order which penetrated the higher strata of the Osmanic empire, as Annemarie Schimmel (Sufismus, Müncher: Beck 2000) writes.

73 But vide footnote 69. 


\section{Christianity}

a. Ancient Christianity

\section{Basic Literature:}

Max Weber, Economy and Society University of California Press 1978

Wolfgang Schluchter, Rationalism, Religion, and Domination University of California

Press 1989 Chapter VI Ancient Christianity: Origins of World Mastery

Wolfgang Schluchter, Max Webers Sicht des antiken Christentums Frankfurt a.M.:

Suhrkamp 1985

Max Weber. The Agrarian Sociology of Ancient Civilizations London: NLB 1976

The Roman Monarchic-Bureaucratic Empire

Max Weber characterized the Roman economy during the time of the principate as coastal, urban, and based on slave labour. There were no facories in the modern sense (no industrial enterprises which deserve this name because of their size, their continuous existence and their division of labour), although there existed the so-called ergasteria (work shops), an undifferentiated accumulation of slave workers.

Weber asked whether a capitalist economy existed in Antiquity to any culturally relevant degree (SAC: 48). In order to answer this question, he had to define the term «capitalist». If we want to talk of capitalism, he said, the enterprise needs a market-oriented basis in a double sense: the products must be sole in the market place, and the means of production must have been bought in the market place for the purpose of economic profit. From this point of view, an enterprise consisting of purchased slaves is a capitalist enterprise, for the slaves were normal market objects which could be bought and sold.. But, of course, it was not a modern capitalist enterprise based on free labour.

Capitalism in Antiquity was not modern rational capitalism, not only because of the use of slaves, but also because capital was used in a different way from today: not in modern factories or enterprises, but by means of tax farming, mining, plantations and ergasteria. Capitalistically used slave property had certain peculiarities. The use of slaves increased the amount of invested capital (as compared to free labour), implied greater risks and largely prevented specialiation and the division of labour. Most importantly, though, it depended on regular new supplies to the slave market by means of military conquests. 
During the time of the polis (the city as an institution in republican Rome, but also in ancient Greece) which had been based on the synoikismos (confraternization and commensality of the urban clans), and when free arms bearing citizens who equipped themselves constituted the military power, capitalism had seen its strongest development. At that time, militarism affected all aspects of social life, in fact, the polis was essentially founded for military purposes (SAC: 346 ) so that ancient capitalism was based on the exploitation for private profit of the political conquests (SAC: 364 ). But during the time of the principate and later, the monarchy in Rome slowly plugged all sources of profit because it became more and more bureaucratized ${ }^{74}$ and relied more and more on liturgical services (supplying its needs by holding specified groups responsible for public tasks). The most important obstacles to capitalism in the Roman empire were therefore political and organizational. Only in passing does Weber consider the possibility that the peoples' mentality may have played a rôle as an obstacle to capitalism as he mentions the contempt of trade and tradesmen by the leisured upper classes and the fact that businessmen were not sustained by any ethical motivation of working in business (SAC: 67).

As soon as Rome declined and the wars of conquest ceased, the regular supply to the slave market dried up. This and the suffocating presence of the bureaucracy which tended to make subjects out of citizens, led to the gradual disappearance of economic trade, the rejection of urban coastal communities in favour of large interior estates, and a barter economy. Civilization became rural until much later during the Middle Ages the city with new characteristics came to life again.

\section{The Spirit of Ancient Christianity}

As in the case of Islam, Max Weber had completed all the preparatory work for an essay on Christianity ${ }^{75}$ when his death intervened. Neverthe-

74 Weber also writes that in the liturgy state created by Diocletian, capitalism found no anchorage (SAC: 364 ). The regulation of the tax system curbed the arbitrary power of the tax farmers ; the tax collecting system was «nationalized» and tax farmers were transformed into state officials.

75 This is mentioned by his wife Marianne Weber in her foreword to vol. III if his Gesammelte Aufsätze zur Religionssoziologie (GARS) Tübingen 1920 
less, there are at least some indications in his published work which can lead to a short outline of his views on ancient, Eastern-Orthodox and Occidental Christianity. This outline has again been partially inspired by Schluchter's work.

Weber believed that the earliest communities of ancient Christianity were strongly urban, to the extent that the word for countryman, paganus, acquired the meaning of heathen. Weber also thought, although the evidence is not strong, that ancient Christianity was characteristically a religion of artisans and wandering journeymen, both slave and free (ES: 481). In fact, Christianity did not originally reject slavery as is confirmed in Paul's letter to Timothy 1.6. ${ }^{76}$ This was a world-rejecting religion and, although the acquisition of money was not forbidden, and Jesus nowhere explicitly stated that preoccupation with wealth leads to unbrotherliness, this notion was at the heart of the matter: the attachment to Mammon constituted one of the most difficult impediments to salvation (ES: 632).

It appears that Weber would have wanted to trace the development of the Jesus movement from within Judaism, particularly in its Pharisaic version, into a distinct and independent religion. He saw the first step in this direction in a sublimation of the Jewish law, i.e. in a revolution of ideas which stressed inner conviction and integrity or the fulfillment of the inner sense of the commandments rather than outwardly correct behaviour and the rational study of sacred law, and which combined this inner conviction with a non-rational attitude of unlimited trust in God (ES: 567). According to Weber, only those who were willing to sacrifice even their own intellect for this relationship of trust were considered to be true disciples of Jesus.

In fact, an inner anti-intellectualism belonged, according to Weber, to the constitutive conditions of ancient Christianity, taking stands against the legalistic scholarship of Judaism as well as against ancient philosophy (ES: 512) and affirming that the «poor in spirit» rather than philosophers and scholars are exemplary Christians. Weber also points in this regard to the formula credo quia absurdum («I believe because it is absurd», a formula often attributed to Tertullian) which may refer to a belief in truth which is superior to reason but perhaps also antagonistic to reason. Even

76 Slavery was justified by natural law theory in its relative form: slavery and political subordination had to be accepted after the Fall as remedies for man's wickedness. Slaves were not even accepted as members of monastic congregations, just as in ancient Buddhist times they were not accepted in the sangha (the order of monks). 
the position of Athanasius (Jesus as being of the same substance as God the Father - an absurd view from a rational point of view, according to Weber) against Arius was for Weber (FMW: 351) an attempt to protect the faith against the intellect or a sacrifice of the intellect. ${ }^{77}$ The virtuosi of the law in Judaism are replaced by the virtuosi of belief, and Christianity's fundamental quality as a religion of belief (pistis) is opposed by Weber to the religiosity of (gnostic) knowledge of Asian salvation religions and to intellectualism in all its forms (ES: 512). ${ }^{78}$

A second step came with Paul who, as Weber conceived him, methodically undertook missions with the goal of organizing congregations on a permanent basis. He went beyond Judaism not only on the level of ideas, but also institutionally. One event, related in his letter to the Galatians II, 12/13, was, according to Weber, of epochal importance (RI: 37): Paul reproaches Peter for having eaten in Antioch with the gentiles and for having withdrawn and separated himself from them afterwards under the influence of the Jerusalemites. As this reproach of dissimulation was not effaced, it points to the shattering by Paul of the ritual barriers against commensalism which the Jews had imposed, the destruction of their voluntary ghetto; and it points to the universalism of Paul's mission which cut across nations, ethnic and status groups so that Christians of Jewish and gentile origins could participate together in the Eucharist. This event of Antioch was also, Weber believed, the hour of conception of the Occidental city even though it only began to flourish more than a thousand years later.

Already the Judaism of the Pharisees was a congregational religion, centered around the synagogues and based on legal and ritualistic principles, but the new Christian congregations since Paul can rather be understood as pneumatic and charismatic congregations. They were tied together, as Weber stated, by the overwhelming importance of the charismatic gifts of the "spirit» and by the expectation of the Second Coming (ES:

77 The idea that Athanasius tried to open a chasm between Greek philosophy and Christian belief (by proposing the doctrine of homousia) in order to avoid the complete Hellenization and secularization of religion and to limit rational thought had already been proposed by A. Harnack in 1889 (Dogmengeschichte, Tübingen 1991, p.178/9).

78 Weber could also have quoted Celsus, an educated Roman, who criticized the Christians for believing without reason ( $\alpha \lambda$ ó $\gamma \omega \varsigma \pi \imath \sigma \tau \varepsilon v ́ o v \sigma v)$ and for inventing dogmas without being able to justify them. Vide Wilhelm Nestle «Die Haupteinwände des antiken Denkens gegen das Christentum» in Archiv für Religionswissenschaften 37 (1941) p. 72 
634). The character of their life was otherworldly and there appeared to exist a total indifference among early Christians to social, political and economic problems, combined, however, with an attitude of caritas towards all and sometimes even with an objectless «acosmism of benevolence and love» (FMW: 330). Weber even talks of the radical rejection of the world in ancient Christianity as opposed to ancient Judaism which he describes as world-adjusted (ES: 633).

But these charismatic-pneumatic congregations which had overcome ethnic and national boundaries and in which the Jewish ritualism and legalism had become sublimated into an ethic of conviction, were not a church, yet.

Four features characterize the emergence of a church, according to Weber (ES: 1164): 1. The rise of a professional priesthood; 2. claims of universal (not just ethnic or national) domination; 3. dogma and rites must have been rationalized and recorded in holy scriptures; and, most importantly, 4. all these features must be realized in such a way that the charisma is separated from person or persons and becomes linked to the institution and particularly to the office. The last feature does not just describe routinization which is the fate of all charismatic domination everywhere, but depersonalization of charisma, i.e. the transfer of charismatic qualities of the original person or persons to social institutions. Office charisma, the belief in the specific state of grace of a social institution, was Weber's example of this phenomenon (ES: 1139), and this is what was developed after the period of the Jesus movement and Pauline Christianity in ancient Christianity.

At its final point of development in the Middle Ages the Christian Church was the first rational bureaucracy in world history, based on rational Roman law and the practical rationalism of the Roman aristocracy which rejected all forms of ecstasy. In order to arrive there, the Church not only followed the path of routinization, but it also received its inner stability from the depersonalization of the original Christian charisma: the ordination combined with the office and its character indelibilis and not any more the personal charismatic qualifications and life style of the priest determined the effectiveness of his distribution of divine grace and of the sacraments; the office was separated from the personal worthiness of the office holder although some, e.g. the Donatists, the first specific sect, strongly objected to this development (ES: 560).

The power of miracles that had emanated from Jesus had become institutionalized. It was realized every time a lay person was dispensed a sacra- 
ment by a priest: Weber saw the Church as a kind of trust fund of eternal goods of salvation (ES: 1164).

Weber judged, as he had mentioned in his essay on China, the level of rationalization of religions by two yardsticks: 1 . The degree to which religion has discarded magic and 2. the degree to which it systematizes man's relationship to the world. While there may have been in ancient Christianity an increase of rationalization in regard to the interpretation of God's commandments, compared to the legal casuistry of ancient Judaism, there was a setback with regard to the disenchantment of the world. Ancient Christianity did not maintain the anti-magical stance of Judaism, for Weber saw in the Christian sacraments an at least partially magical quality. Only Protestantism much later revoked this magical power of the sacraments.

\section{b. Eastern Orthodox Christianity}

\section{Basic Literature:}

Max Weber, Economy and Society University of California Press 1978

Andreas Buss, «The Economic Ethics of Russian-Orthodox Christianity», Part 1 \& 2 in: International Sociology vol. 4 (no. 3 \& 4) 1989

Andreas Buss, Max Weber and Asia München: Weltforum 1985 (Chapter 5: The Petrifaction of Western Science and Culture and Max Weber's Interest in Russia)

Richard Pipes, Russia under the Old Regime New York: Scribner's 1974

Weber's essays about the other world religions were written for the purpose of understanding aspects of Western civilization. His interest in Eastern Orthodox Christianity and particularly in its Russian expression, however, was also guided by his desire to find solutions and alternatives to the historical and political situation of his day. He studied the Russian language, wrote articles about the Russian revolution of 1905, and planned to write a book about Leo Tolstoy. He believed that in the characters of Russian fiction, e.g. Dostoyevsky's Brothers Karamazov or Tostoy's War and Peace, one finds represented antique Christian ideas which seem to have been lost in the Occident. Weber even started to look at Western civilization through the eyes of the Russian Slavophiles (Khomyakov, Kireevsky) who had pointed to and criticized the West's lonely individuals in an atomized society, its Roman heritage, the rationalism of its jurisprudence, and its social contract theories. According the the Slavophiles, the creation 
of the Western state as well as of the Occidental Church was the work of jurists, - a view, which Weber accepted. ${ }^{79}$ His views of Russian-Orthodox Christianity will be summarized here.

\section{The Patrimonial State}

Russia has been an inland area of strongly agricultural character where the yield was comparatively poor, but it also had a network of navigable waterways which facilitated trade. Since the Normans invaded Russia and made Kiev their headquarters in their trade with Constantinople around the tenth century, traders have sailed on the Russian rivers, and the city of Novgorod in the North-West was in close contact with the Hanseatic league.

But the rulers of Moscow who slowly expanded their power considered their country with the eyes of landlords as their property (votchina). The administration of the developing state evolved out of the patriarchal administration of the rulers' private domain into a patrimonial administration (ES: 1013). After the collaps of the Byzantine empire in 1453, the Muscovite princes increasingly thought of themselves as the defenders of Orthodox Christianity and began to adopt the title of tsar (Caesar); at the same time, though, they continued to consider themselves as the owners of the state and all the land, and the political administration as their private affair. The slowly growing patrimonial bureaucracy operated in purely personal submission to the ruler so that it served only him and not impersonal purposes. Russian feudalism did not develop a tradition of contractual agreement between the boyars (nobles) and the patrimonial ruler, and therefore had no vassals in the Occidental sense.

The population was easily divided into four groups: the nobility, the monastic and clerical estate, the peasantry and the urban population. They all were treated differently in regard to taxes, legal matters and military service. The old nobility, the boyars, slowly saw their freedoms reduced by the princes of Moscow so that their properties became tied to services to the ruler. Moreover, a service nobility (dvorianstvo) was created and received service fiefs (pomest'e) which could not be sold or bequeathed. In

79 Andreas Buss The Russian-Orthodox Tradition and Modernity Leiden: Brill 2003 p. 122 
fact, the concept of the sacredness of private property (allodial property) did hardly exist; property was generally tied to services, at least until 1785 (Catherine II). The system of mestnichestvo which determined social ranking forced the nobility to enter the patrimonial bureaucracy for the sake of preserving social status and career chances. The chin (rank) within the patrimonial bureaucracy later became the official basis of social prestige, and all opportunities for economic advancement depended upon office holding. Because the officials were often moved between the various branches of the administration (military, judiciary, diplomacy), modern specialized knowledge was generally lacking. Weber underlined (ES: 1068) that one fundamental feature of medieval Western nobility could not develop in Russia: an internalised conduct of life and a common social honour as it was created by the occidental knighthood. Economic interests and the desire of advancement propelled the nobles in Russia, not an inner standard of self-assertion based on fealty and a contractual relationship between a vassal and his king. This was a prebendal feudalism as it tends to develop under patrimonial domination.

Cities in the occidental sense with liberties and autonomous status have not existed in Russia or, as in the case of Novgorod, were soon subjected to the tsar. There were no guilds in Russia before they were created by the government in the eighteenth century according to the level of income of merchants and traders. But even the richest merchants made every effort to be raised into the nobility and into the public service rather than to invest and to expand their business, for every financial loss could result in the descent into a lower guild. Thus, there was no status solidarity among the citizens. Well into the middle of the nineteenth century there was virtually no commercial credit or banking nor a rational concept of corporation as it was produced in Western commercial law. The situation of the merchants was often precarious and they had to fear the nobles and even the Tsar who sometimes seized hold of their commodities.

During the Middle Ages the Russian peasants were free, but since the sixteenth century the bonds of serfdom gradually deprived them of their freedom of movement and tied them to the land, to the jurisdiction of the dvorianstvo (office nobility), and to their mir (village community). Russian law, as Max Weber has noted (ES: 725), recognized liturgical collective liability and the corresponding collective rights of the compulsory organizations, e.g. the village communities. Peasants as well as the merchant guilds owed the state a variety of obligations in money or labour, and they were jointly (as village community or as a guild) accountable for the ser- 
vices imposed on their group. The system of liturgies, as Weber called this system of the satisfaction of state needs (ES: 1097), was applied comprehensively by many patrimonial-bureaucratic empires of Antiquity, and everywhere it reduced private capital formation ${ }^{80}$ as it discouraged the most successful and entrepreneurial of the respective group who were expected to contribute more. The retention of the mir after the emancipation of the serfs inhibited the emergence of a vigorous farming class, because the enterprising members of the mir had to share the financial burdens with the incapable and unwilling ones.

On the whole, it may be said that the patrimonial state blocked the development of commercial capitalism (but not of political capitalism) because of the lack of a rationally calculable functioning of administration and jurisdiction, and because of the lack of a clear separation between them.

\section{The Orthodox Church}

When in 988 Prince Vladimir of Kiev was converted to the Christian faith of Byzantium, the classical conception of the emperor as rex-sacerdos (king and priest), a caesaro-papistic ruler, continued to survive. In Constantinople a strong state and an old civilization englobed the Church. Russian rulers since the beginning, and later the tsars, adopted the caesaropapistic conception of the ruler, totally different from what was to develop in the Western Christian tradition since the dictatus papae of Pope Gregory VII who claimed that the state was simply the political branch of the Church.

Moreover, a deadly conflict had developed between two kinds of monasticism in Russia: on the one hand the so-called hermitage monasticism which turned away from politics and church hierarchy and pursued missionary activities in northern Russia and Siberia, and, on the other hand, the cenobitic monasticism which was friendly towards the state and upheld the principle of monastic land-holding. The cenobitic Josephite monks prevailed with the help of the Moscovite princes (ES: 513) and this led to the petrifaction of religious life and to the idea that the Russian tsars

80 The notion of liturgy is derived from a Greek verb (leiturgeo) which means that someone administers a public office and defrays the costs connected to it out of his own pocket. 
(after the fall of Constantinople in 1453 to the Turks) should rule all Orthodox people as well as the Orthodox Church which became totally dependent on the state. The resulting caesaro-papism eliminated all possibility that Eastern canon law would develop further by means of conciliar legislation and would influence economic and political life. Later, under Peter the Great, even the patriarchate of the Church was abolished and became a branch of the patrimonial bureaucracy (ES: 830/1). Weber wrote that «magic- ritual forces were controlled most thoroughly in the ancient polis, rather well by the feudal powers in Japan and the patrimonial ones in China, and reasonably well by the bureaucratic state in Byzantium and Russia» (ES: 1161).

While in the West the dualism of emperorship and papacy during the Middle Ages developed as a form of status plurality and also strengthened other status positions (nobility, cities), any tension between state and church was lacking in Russia and no autonomous nobility or independent bourgeoisie could develop either.

Monasticism in the Eastern-Orthodox tradition was connected with the official church in a particular way. While in the West monasticism was subdivided into functionally different monastic orders which were active as the «auxiliary troops» of the Church in missionary work, hospital work, education, or even as orders of knights, and while in this way, as Weber said (ES: 1167), the monks left the monastic cell and tried to dominate the world, the Eastern Church in principle facilitated the complete separation of the monk from the «world» and his complete abandonment to prayer and contemplation. But a compromise was achieved already by a decision of the Trullan Council in 691 that only monks can become bishops (while the ordinary priests of the Orthodox Church had to be married). This relationship between Church and monasticism was, according to Weber, inconsistent (because of the mechanical combination of personal charisma and office charisma) and could be explained only because the development of an independent hierocracy had been deflected by caesaro-papism.

\section{The «Spirit» of the Orthodox Church}

The «spirit» which lived within this patrimonially governed church was composed of magical, ritual and mystical aspects. In reference to magical ideas, Weber mentioned the veneration of icons and that the fear of giving serious affront to two dozen saints by omitting in one year the days sacred 
to them has hindered the reception of the Gregorian calendar until the beginning of the twentieth century (ES: 405). In general, Weber believed, peasants much more than urban artisans try to coerce their gods by magical means. But there also existed, among the religious elites, a kind of antique mysticism which considered the rites of the Church as guides and direction to mystical experience and which revealed itself in the fact that the highest authority which decides who belongs to the Church and which religious teachings are dogmatically correct is the church as a communal group united in love, the consensus ecclesiae (ASS: 466), - and not the Pope as in the Catholic Church, nor the Scriptures, as in the Lutheran Church. ${ }^{81}$ The mystical vision of God, moreover, was not a heterodox movement, but it was central.

Mysticism, in Weber's terminology, is set in opposition to asceticism. $\mathrm{He}$ connected asceticism with activity proving one's religious merit in the world; in mysticism he saw passive contemplation and quiet repose in God. ${ }^{82}$. The ascetic affirms rational activity within the world as God's instrument, the mystic regards action within the world as a temptation against which he must maintain his state of grace as God's vessel. Activities of the mystic within the world are minimized and are characterized by a distinctive «brokenness», because success in the world has no significance with respect to salvation (ES: 549) and because of an inner conviction of the senselessness of this politically, socially and artistically formed life. The consequence is a relative indifference towards the world.

Eastern Christianity did not adopt the Western idea of a legal relationship between God and the human being (which was developed since Anselm of Canterburry and also appears in the doctrine of justification by

81 According to A. Khomyakov's epistemology, the possession of truth is not a function of individual consciousness ; truth is inaccessible to individual thinkers who have only partial knowledge or rationality. Only sobornost' (togetherness of people united in faith) makes true understanding possible (vide: Buss 2003: 122). Khomyakov was a leading figure among the Slavophiles.

82 Mysticism and asceticism have also been linked by Weber to the concept of the divine - be it the concept of a transcendent and omnipotent god in Western religious traditions, be it that of an impersonal immanent order as in the great religions of Asia. The concept of a transcendent god leads to asceticism and to seeing oneself as an instrument of God while mystics see themselves as passive vessels of immanent divinity. But there is no necessary correlation as can be seen in the Russian-Orthodox tradition which, in spite of its mystical tendencies conceived God as transcendent and is in this respect internally «broken» (ES: 551). 
faith in parts of Protestant theology). Orthodox Christians are convinced that sinful actions imply only a diminution of their goodness and not a violation of their legal relationship with God; they are convinced that they themselves can become similar to God and attain theosis.

An economic ethic in the narrow sense of the term which might have settled the question of the «just price» and of the justification of interest taking was not developed because of the Orthodox indifference towards the world. The highest psychological premia were not placed on vocational activity within the world but on contemplation and on the anchoretic life style of monasticism which was considered to be the perfection of human life. There was no religious motivation for a rational and methodical reorganization of the world or for capitalistic gain in the pursuit of a vocation. No inner motivation led out of the spiritual conditions of the Orthodox Church to a reorganization of political and economic life. The proof of one's own value was produced against the «world» and worldly activities, not in and by them.

No Renaissance, no Humanism, no Protestantism have opposed the «spirit» of Orthodoxy. Even a development of science out of its own roots did not take place, partially because the rational form of a systematic theology (the Summae of Thomas Aquinas) was not developed; and a formally rational law did not appear because Orthodox canon law remained stifled under the caesaro-papistic government. There were no strong and independent institutional or spiritual powers, no city bourgeoisie, no independent nobility or hierarchy and no ethical prophecy which could brake open the strong cage of the patrimonial state.

\section{Russian Old Believers}

In the seventeenth century, when the Patriarch Nikon, supported by Tsar Alexis, had introduced several liturgical reforms, a schism (raskol) split the Russian Church in two. It appeared about seemingly trivial questions, but, in the opinion of the Old Believers, as they were called, a religious ceremony, incorrectly performed, has no effect and no value before God. This insistence on correct ritual implied a fundamental difference from Western Protestantism which had little interest in what it considered to be mere exterior forms.

About the same time there was in Russia an eschatological mood, the expectation of the arrival of the Antichrist whose significance for the 
raskol should not be underestimated. The Old Believers who broke with the official Church and with the state - for the official Church was closely tied to the state and to the ruler, the tsar, considerd by them as the Antichrist - now faced many further decisions concerning not only the ritual but also their conduct of life. A Church Council excommunicated them, their leader Avvakum was burned at the stake, many of them fled into the uninhabited woods, they were excluded from elective offices and there were waves of mass suicide. Nevertheless, the number of Old Believers increased in the subsequent centuries and in general they became also more prosperous than the members of the official church. There was a preference for hiring Old Believers as industrial laboureres because of their honesty and their temperance, and they also enjoyed the reputation of being the most honest businessmen. But, although they were considered to be honest, frugal, industrious and thrifty, it can in no way be said that the connection which Max Weber saw between ascetic Calvinism and the development of modern capitalism can also be observed in the case of the Old Believers.

A practical problem of the Old Believers resulted from the fact that no bishop had joined the schism and that therefore no new priests could be ordained. One part of the Old Believers, the priestists (popovtsy), decided to accept priests ordained by the official church, the others, the so-called priestless (bezpopovtsy), arrived at the view that some sacraments ( the sacrament of marriage in particular) were not accessible any more and that they had to remain unmarried. Here is an example of the fact that religious positions can have other sources than the social conditions of the strata which support them, namely the inner consistency of logic which, against the requirements of interests and tradition, leads to certain consequences.

To the extent that the influence of the priests diminished, the Old Believers developed the character of a congregational religion, i.e. a religion which was influenced to a large extent by the laity. Weber talks of congregational religion when the laity has been organized permanently in such a manner that they can actively participate and make their influence felt - as opposed to a parish which is a mere administrative unit and delimits the jurisdiction of priests (ES: 455). ${ }^{83}$ This refers not only to the bezpopovtsy but also to the popovtsy, for they subjected the priests who deserted from

83 Rational ethical congregational religions have combined frequently in the past and in a striking manner, according to Weber, with capital rationally employed in a productive enterprise for the acquisition of profit (ES: 479). 
the official church and came to them to a humiliating procedure and treated them more as employees than as religious shepherds. Therefore, there was more self-responsibility and their conduct of life became more methodical and systematic. Nevertheless, the Old Believers, in contrast to ascetic Protestantism, kept the magical and ritualistic aspects of Orthodox Christianity and the world remained for them a magic garden.

The Vyg monastery near the White Sea, founded by a group of priestless Old Believers, where the severe northern climate often destroyed entire crops of grain, became a religious and cultural center. It followed strict norms of congregational discipline, the general assembly decided on questions of dogma and of ritual and about political questions. They put an emphasis on the benefits of hard work and on basic education, indispensible to read the Scriptures. The more or less passive resistance of the Vyg inhabitants towards the tsarist government can be characterized as pariahethical. Their attitude towards the world was not world-domination, nor world-indifference, but rather an attitude of world-endurance, combined with passive resistance.

The situation of the Old Believers was relieved under Catherine II who repealed many discriminating laws. Now, Old Believers took charge of most of the economic activities in the areas of the middle and lower Volga and of the state-owned iron foundries in the Urals. The Theodosians, an ascetic branch of the priestless Old Believers, founded during a plague epidemic in Moscow a cemetary combined with a home for the aged and a hospital; soon, some chapels and shops were added and the activities extended into the commercial field. But the Theodosians remained hostile to private property, sex and marriage and kept away from everything connected with the state as belonging to the Antichrist. While according to Weber the Puritans had a world-dominating attitude, it was the tendency of the Theodosians to strenthen the personality ideal of the world-renouncing monk.

In the nineteenth century, there were Old Believers among the richest merchants in Moscow, but Weber's opinion about them was full of nuances. The inner-worldly asceticism which can be noticed in the life-style of most Old Believers, was broken by traditionalism, ritualism and magical influences in the search for salvation. Thriftiness in the patriarchal household and insistence on hard work amounts to worldly wisdom and to literary theory (as for instance in the old Domostroi), in any case not to be compared with the religious motives of the ascetic Protestants who sought the proof of their own value in their inner-worldly calling. Nevertheless, 
the increase of personal responsiblility, produced by the development of congregational religion, moreover their solidary mutual help contributed to the economic success of the Old Believers. It goes without saying, that the persecutions by the government and the official Church as well as the exclusion from public life furthered individualism and commercial abilities as in the case of many other minorities (Jews, Parsis, Copts).

\section{The Russian Sects}

Russian sects, in contrast to the Orthodox Church and the Old Believers, had little interest in ritual and magical means of salvation.

The Khlysty, who are usually considerd to be the root of Russian sectarianism, believed in the repeated reincarnation of Christ in living human beings. Salvation for them consisted in the liberation of the soul from the body, and this was possible, according to them, at least temporarily, by ecstatic contemplation of the Spirit of God, the so-called radenie, during a religious-ecstatic dance. In order to prepare for the radenie the ascetic suppression of all physical urges and desires was required, including fasting and the avoidance of sexual relations even with one's own wife.

This was perhaps an attempt to turn monastic asceticism into the required life-style of everyone and thus a parallel to Western Protestantism, but Western Protestantism was inner-wordly and resulted in the attitude of world domination while the attitude of the Khlysty was world-fleeing, or at least world indifferent. For religious reasons, but also because of the persecutions by the tsarist government they upheld a strict disciplina arcani (they kept their beliefs and practices secret; officially they continued to belong to the Orthodox Church, but they disdained its practices and met in private locations). Their congregational discipline may help to explain their honesty and industriousness, but their world-fleeing asceticism and their ecstatic dances as means of salvation could not produce a rational conduct of life in the world, although their thrifty life-style produced relatively well-ordered economic conditions.

Occasionally, some Khlysty may have had sexual relations after their exstatic dances. The foundation of the Skoptsy sect by K. Selivanov reflected the desire to eliminate such possibilities (ES: 602). Selivanov castrated himself and considered castration as the only means of salvation. His followers, the Skoptsy (castrated), were an essentially ascetic sect in which castration was the highest means of salvation (ES: 540) and which 
in any case did not allow sexual relations, the consumption of meat, alcohol, gaiety and aimless strolls. Like the Khlysty, they followed the disciplina arcani in the belief that religious achievements lose their value if they are made known to other people. At the same time, their secrecy protected them from prosecutions. Theirs was an icy individualism which followed from the separation of the castrated from all societal life and produced an impersonal conduct of life similar to ascetic Protestantism, even in the political and economic field. They did not worship icons and they had only contempt for the sacraments of the Orthodox Church.

In their emphasis on asceticism, in contrast to the mysticism of the Orthodox Church, the Skoptsy were less inclined to consider themselves as vessels of the divine Spirit, but rather as tools in the plan of the world in which Christ and Selivanov had a central position: they considerd it to be their task to increase and complete the number of Skoptsy so that the Millennium of the Skoptsy may be created.

They lived mainly in urban centers and were active in commerce, industry and banking. Their striving for wealth was motivated in part by the financial possibility to bribe the officials in order to deflect the sometimes intense persecutions. But there were also inner motives: a cold individualism and an unbrotherly calculating attitude in human relations; further the rejection of all sacramental means of salvation and the ascetic life-style connected with it - and all this reinforced by their strict congregational discipline. Max Weber writes that the rational-ascetic Russian sects (not all sects) had economic features similar to those of ascetic Protestantism and that the Skoptsy produced the most extreme combination of business qualification with ethical world rejection (PE: 2: 154 \& 321).

In the Ukraine there appeared in the eighteenth century the so-called «Spiritual Christianity», mainly composed of the sects of the Dukhobors and the Molokans. They rejected the traditional forms of the Orhtodox ritual as well as fasting, icons and priesthood. Decisive for them was the gnostic opposition between spirit and matter. Only the inner spirit really exists, they said, and the body is but a temporary prison. The goal of salvation is to restore God's image in man and to break the material bonds. They rejected all government authority, refused military service and lived on the basis of common property.

The communities of the Dukhobors achieved considerable economic prosperity, and their religion must be mentioned among the reasons for this: the rejection of icons and of ritual as magical means of salvation as 
well as the control of their life produced by their congregational discipline.

The Molokans who split off from the Dukhobors were the most numerous sect in the nineteenth century and were considered by the government as particularly harmful. They taught that the sacrament of baptism is performed whenever someone leads a Christian life without sins. Thus baptism, instead of being a single ritual act, was for them a continuous conduct of life, expressed in sobriety, honesty and industriousness. They also taught that worldly authority and human laws are only meant for the "children of the world», but not for «Spiritual Christians»; they therefore rejected serfdom, military service and the taking of oaths. Russian anthorities have written that they were richer, in spite of the persecutions, than the Orthodox population and even the Dukhobors.

The Stundists, also mentioned by Weber, - the movement seems to have originated among German colonists - had particularly strong anti-ritualistic tendencies, rejected fasting, icons and priesthood, and were industrious and thrifty. They upheld private property but often opposed commerce and the use of money.

Result

The Orthodox religion offered several different forms of salvation according to the different social strata. The peasant masses with their magical world-views contrasted with the personality ideal of the monk with his mystical world view. The Old Believers and sects were unable to free themselves from the caesaro-papistic patrimonial state and this led to passive apolitism and sometimes to pariah-ethics. Weber also mentioned the specific character of the Russian natural law which is based on the concept of community and not of society (ASS: 467). The religion of both Old Believers and sectarians was generally congregational and lay people played an important rôle as intellectuals and administrators. The ecclesiastical discipline was, however, hampered, in the case of the Old Believers, by traditionalism and ritualism. The rejection of religious rites, icons and sacraments by many sects, i.e. the rejection of magical positions, led to the necessity for the sect members to attain the certitudo salutis by their own efforts without a mediator, it led to a more rational conduct of life, possible also in the economic sphere. This was the case particularly among the Skoptsy and among the Molokans. Russian sectarians also abolished the 
distinction between monastic ethics and lay ethics, but without the consequence of the Protestant Ethic in the Western sense.

\section{c. Occidental Christianity}

\section{Basic Literature:}

Max Weber, Economy and Society University of California Press 1978

Wolfgang Schluchter, Paradoxes of Modernity Stanford University Press 1996 Chapter 4: The Emergence of Modernity: Max Weber on Western Christianity pp. 179-243

Wolfgang Schluchter (Hg.), Max Webers Sicht des okzidentalen Christentums Frankfurt a.M.: Suhrkamp 1988

Harold J. Berman, Law and Revolution Harvard University Press 1983

Finally, Weber had the intention to set his Protestant ethic studies in the general framework of Occidental Christianity as a whole and to answer the question as to what constitutes the distinctive economic, social, and legal characteristics of the singularity of the development of the Occident. Of course, as he had done in his essays on India and China, he would have considered the institutional and legal characteristics and transformations as well as the motivational characteristics and finally their interconnections (the degree of affinity between the institutions and the inner motivational forces).

The Institutional and Legal Transformations

The institutional and legal transformations which interested Weber, as they produced the external historical preconditions of modern capitalism, took place from the eleventh to the thirteenth century: the so-called Papal Revolution (Weber did not use this more recent term) with the Investiture Struggle and the development of canon law, Western feudalism, and the rise of the Occidental city.

The reasons for the transformation of the outworldly situation of ancient Christianity to a more inworldly situation of later occidental Christianity have not been described by Weber in any detail, but a study by 
Louis Dumont will complete the view. ${ }^{84}$ While in early Christianity the individual as a value was conceived as outworldly, as apart from the given social and political organization (and similar to the religious renouncers or samnyasins in India), the conversion of Constantine and then of the Roman Empire to Christianity forced upon the Church a closer relation to the State. The first clear but still traditional result was Pope Gelasius' formula (around the year 500) about the relationship between the pope's auctoritas (authority) and the king's or emperor's potestas (power). But a dramatic change occurred in the eighth century when a Frankish king was given the rôle of protector of the Roman Church by a pope and when Charlemagne was crowned as emperor in Rome by another pope in the year 800 . The popes thus broke their ties with Constantinople and claimed superior political power in the western part of the Roman Empire, not only auctoritas but also potestas.

This claim was then based on the forged so-called Donation of Constantine (the Donatio Constantini, on the basis of which the popes also claimed sovereign political authority in a part of Italy), and later justified in the theory of the two swords. A significant ideological change occurred here, for the sacerdotium (the spiritual function) claimed to rule in worldly matters. The Church now became «inworldly», according to Dumont, and the difference between spiritual and temporal power became one of degree and not of kind. Conversely, the previously outworldly individual became more inworldly, for since the Church pretended to rule the world this meant that the Christian individual was now committed to the world and this was going to lead to the the formation of the modern individualist ideology (the ideology which makes us believe that we are autonomous individuals). The unified culture (Einheitskultur) of the Middle Age, as Troeltsch has characterized it, started to break up. Weber did not deny the existence of a unified culture based on the teachings of the Church, but he was more interested in the organizational diversity which was developing under the unifying canopy. The final stage will later be found in Calvin who suggested that the task of the individual is to work for God's glory in the world rather than taking refuge from it, and with whom the Church becomes a society of inworldly individuals and a mere instrument of discipline.

84 Louis Dumont «A Modified View of Our Origins. The Christian Beginnings of Modern Individualism» in: Religion (1982) 12, pp. 1-27 
While previously, just as in Eastern-Orthodox countries, there had been a tradition of caesaro-papistic domination, the Papal Revolution in the West - soon after the schism between Rome and Constantinople or between Eastern and Western Christianity - put an end to it and even attempted to impose a theocracy (Gregory VII in his Dictatus Papae of 1075, and then Innocent III), the pope claiming not only religious but also political superiority over the emperor in secular matters, including the authority to depose and to excommunicate emperor or king. Ultimately though, the Investiture Struggle resulted in a tension-filled dualism between the religious and the political domain in the Concordat of Worms of 1122 , a pact with the force of international law between the ecclesiastical and the secular authority.

The result was a clear dualism of jurisdictions, a separation of ecclesiastical and secular authority, and the systematization of canon law which became the first modern Western legal system and also, as Weber mentioned, one of the guides of secular law on its road to rationality. The Occidental Christian Church created for itself organs of rational law-making in the Councils, in its bureaucracy, and in the papal powers of jurisdiction which no other of the great religions did ever possess (ES: 792). The term «corporation» may be used in this context: in Roman law, the state was considered to be a corporation, and so were municipalities, with the right to own property and to conclude contracts; guilds of craftsmen and traders, churches and monasteries were also corporations and could act as juristic persons to the extent that these privileges were granted by imperial authority. But the canon law added a completely new idea: the whole Church, the Church Universal, became a corporation, independent of emperors and kings and able to create new positive written law for its members by rational enactments of church councils and synods.

Weber considered the medieval Catholic Church as the first rational bureaucracy in world history and he added that it took the form of a compulsory institution ${ }^{85}$, an Anstalt. Its canon law was a coherent ecclesiastical

85 Weber distinguished between corporation and institution/compulsory organization (Anstalt). In both cases there is a legal distinction between the whole and its members, but while the corporation is simply a fixed group of persons who can be replaced in prescribed ways, an Anstalt imposes, within a specifiable sphere of operations, its order (with relative success) on all action conforming with certain criteria (ES: 52); it has mainly administrative organs, rationally established rules and generally obligatory membership, although the members have no influence on the 
law which, although quite independent, markedly influenced the development of the secular corporation in the Middle Ages (ES: 714/5). Although the legal concept of the institution (Anstalt) was not fully developed before the modern period, as Weber admitted, he thought that it was bound to arise in some manner when the original charisma of the early Church leaders disappeared and the new official bureaucracy of the bishops needed technical legitimation for the exercise of ecclesiastical rights of property - for in Antiquity religious properties like temple assets or church buildings belonged to the polis (ES: 714).

Weber also considered the Gregorian reforms as a decisive step in the development of the Western Church as an institution of sacramental grace (ES: 560) in which the ultimate religious value is pure obedience to the Church which can provide absolution, and not the fulfillment of concrete ethical duties, not even the supererogatory duties of the monks. The Church was a hierocratic organization, an organization which claimed the monopoly of enforcing its order through psychic coercion by distributing or denying religious goods (ES: 54 ) - as opposed to the State which enforces its order by exercising the monopoly of physical coercion.

In fact, Gregory's reforms also addressed themselves to the monastic orders and introduced important reforms for them. Asceticism and monasticism no longer were ends in themselves, to be lived outside the «world», but they became means which served the general aims of the Church. Monks became the «auxiliary troops» of the Pope with well-defined roles; they were integrated into the bureaucratic ecclesiastical organization, subject to a specific discipline, living according to the consilia evangelica and removed from everyday life by the vows of poverty, chastity and obedience (ES: 1168). But even the mendiant monks, in contrast to Buddhist monks or even the monks of early Chistianity, were forced into the service of the Church and compelled to serve rational purposes (preaching, systematic charity, education etc.). Anchorites were not even mentioned in the canon law of the Catholic Church. The principle was: extra ecclesiam nulla salus (outside of the Church there is no salvation).

Moreover, for Weber the monastic communities of the Occident were the first rationally administered manorial organizations and the occidental

administration (ES: 707). Weber considered the Church to be an Anstalt, although he admitted that the transition between corporation and Anstalt is gradual and fluid. It should be noted that in Economy and Society the term is variously translated as institution or as compulsory organization. 
monk the first vocational man (ES: 1169). While in other religious traditions the monk is a mendicant or itinerant and represents the proptotype of an anti-economic seeker of salvation, in Occidental monasticism labour as an ascetic means of salvation and as an economic instrument - the Benedictine formula ora et labora (pray and work) may serve an an example was developed far more consistently (ES: 1170). The Cistercians with their rational organization of agriculture and their well-known achievements in colonization, can be said to have organized some of the first rational enterprises (ES: 1182). Only ascetic Protestantism made the additional step of transferring rational ascetism into the world. But while the monks were able to develop an ethically systematized method of life, according to Weber, they were still dependent on the institutional sacramental grace of the Church and thus somehow midway between Catholic laity and the future ascetic Protestants.

The state in the modern sense did not exist yet, but there were emerging secular legal systems in England under Henry II, and on the Continent Roman law started to take hold under the emperor Frederick Barbarossa. And there were secular legal subsystems. One aspect of the socio-political structure which Weber would certainly have considered was the rise of Occidental feudalism, based on fiefs and not, as for instance in the Islamic tradition, on prebends. ${ }^{86}$ This feudalism was not only a marginal case of patrimonialism, it was at the same time a routinized charismatic relationship, related to its military origins and to an education which favoured the individual heroic battle between warriors and a mentality based on honour. Rather contradictory elements were merged: strictly personal fealty between lord and vassal, contractual stipulations of rights and duties and finally a depersonalization of the personal relationship by virtue of a rentproviding fief (ES 1074). This Occidental feudalism led, according to Weber, to a unified code of conduct, based on an ethic of honour, clearly different from a religious ethic based on salvation. This conduct of life implied the complete opposite of a rational economic mentality and was, ac-

86 The prebend (benefice) is a lifelong remuneration for services within a patrimonial regime, the prebend-holder a rentier or usufructuary with official duties. In contrast, the free vassal who has a fief stands outside any patrimonial subordination and is subject to a code of duties and of honour. As opposed to dignity which pertains to the individual regardless of his position in society, honour implies that identity is essentially linked to institutional roles and dishonour implies a loss of face in the community (vide also Peter Berger 1973). 
cording to Weber, the source of a certain «nonchalance» in business affairs, but it was an innerworldly conduct of life nevertheless.

Apart from this conduct of life based on honour, feudalism also produced, because of the fief-holder's position through a bilateral contract with his lord, the idea of the contractual character of political power which, in comparison to pure patrimonial domination, introduced an approximation of a state ruled by law (Rechtsstaat; ES: 1082), of property rights and individual rights. In England this led to the Magna Carta (1215). The idea of a social contract, an idea which led to modern constitutionalism, is here anticipated in a primitive fashion.

And finally, there was the rise of the Occidental city which, according to Weber, had, in universal-historical terms, a special position if compared to Asian cities or the cities of Antiquity. While the hereditary caste structure in India, with its ritual separation of the occupations, precluded the emergence of the confraternization of the burghers into a city corporation, and while in fact in all Asian cities the kin group associations ruled out the existence of a city «commune», the Occidental medieval city was not only a seat of trade and crafts and their respective guilds, but it was also a sworn confraternity with its own charter (ES: 1248). Its citizens were subject to a special autonomous law, and they could be considered as a distinct «estate» with its own privileges and with the legal status of citizenship. The city was an autonomous, autocephalous and anti-feudal corporation. It imposed its own statutes, levied taxes and launched economic policies of its own, but it did not apply ecclesiastical law or perform sacred rites; its task was to maintain peace and justice, for the bearers of private enterprise, the citizens, needed peace for their affairs, whereas the citizens of the antique polis needed wars for their political capitalism. The city was economically oriented, the citizen was a homo economicus, whereas in Antiquity the citizen of the polis (city) was a homo politicus (ES: 1354). Weber reminds his readers of the Christian preconditions of the fraternization of the city burghers: the events in Antioch and the elimination of all ritual and kinship barriers, as described in Paul's letter to the Ephesans. ${ }^{87}$

In the cities, particularly in Italy, there also developed new legal principles in mercantile law which allowed the legal separation and the separation for accounting purposes of private and business spheres, of the house-

87 Described in more detail in the section on ancient Christianity above. 
hold and of the «firm», as Weber had noted ${ }^{88}$ : the commenda, a kind of joint stock company for a single venture, and a varation of it, the societas maris. Unlimited partnerships and the domestic system (GEH: 153) developed early, but more and more, continuous capitalist acquisition was performed in a separate enterprise. The identity of household and office fell apart, business assets and private property were separated. The advantage of these arrangements was that the liability of the partners was limited to the amount of their initial investment and it implied limited joint liability. The partnerships were corporations and therefore juristic persons. Bonds, stock certificates, bills of exchange, and the beginnings of bankruptcy law followed. This fundamentally important development was a characteristic feature of the Occident; it characterizes the qualitative uniqueness of the development of modern capitalism (ES: 379). Certainly, the medieval city was a historical interlude, but, though not the only significant antecedent developmental stage, it can be linked as one of the crucial factors with the rise of modern capitalism and the modern state (ES: 1323).

The «Spirit» of Traditionalism and the Puritan Sects

The economic ethics of the Middle Ages and even of the Renaissance were largely based on the «spirit» of traditionalism so that an inner affinity between commercial activity and the innermost core of the personality was lacking (AC: 117). The devout Catholic, as he went about his econonomic affairs, found himself continually behaving in a manner that transgressed papal injunctions. His economic behaviour could be permissible only on the basis of a lax probabilistic morality (ES: 615). Homo mercator deo placere vix potest (merchants can hardly please God) was a formula of the Corpus Iuris Canonici (canon law). Economic activity was not considered as immoral, but as morally neutral or indifferent. The Latin formula implied, in fact, a high degree of concession on the part of the Catholic doctrine to the financial powers in the Italian cities: they were allowed to make a profit, but this did not provide any hope of salvation.

88 In: Geschichte der Handelsgesellschaften im Mittelalter 1889, now translated as The History of Commercial Partnerships in the Middle Ages (2003). The theory of corporations which developed slowly distinguishes between the property, liabilities and assets of the corporation and those of individual members. 
The history of the prohibition of interest taking is rather complicated. The Christian Church, including the popes, took interest without any scruples in the early Middle Ages, but as in all salvation religions, there was hostility towards the power of capital which is impersonal and not amenable to ethical control, as Weber explained. However, there was also accommodation to practical needs as can be seen in the canonical distinction between interest and usury (shameful profit). Persecution of usurious lending arose as a concomitant of the incipient development of actual capitalist instruments; it was the result of a struggle in principle of ethical rationalization and the rationalization in the domain of economics (ES: 584). In any case, officially the prohibition of interest was not abolished until the nineteenth century (PE: 151, n. 29). The accommodation was possible because the Catholic Church remained a sacramental institution of grace. "Quite realistically the Church recognized that man was not a clearly defined unity to be judged one way or the other, but that his moral life was normally subject to conflicting motives and his action contradictory. Of course it required as an ideal a fundamental change of life. But the Church weakened this requirement for the average person by one of its most important means of power and education, the sacrament of absolution, the function of which was connected with the deepest roots of Catholic religiosity» (PE: 70). Institutional grace was provided by purely magical sacraments because the institution was deemed to control the accumulation of grace producing supererogatory achievements of its officials or of monks (ES: 560).

In general, Catholic traditionalism implied a non-methodological sequence of single actions. The Catholic knew that he could obtain absolution from his sins in the confession, for the Church gave grace to the just and the unjust. The veneration of the saints, according to Weber, led practically to polytheism, and even the Holy Communion contained magical aspects. Only the monks surpassed the lay ethics with supererogatory works and achieved a methodical (though outworldly) way of life.

But if economic traditionalism was to be broken, the toleration of economic acquisition was not enough, nor was worldly or economic wisdom sufficient. Only Protestantism in the sixteenth century eliminated all sacramental and institutional grace and insisted on the proof of one's salvation by innerworldly asceticism which led to a deep moralization of life, or to a life-transforming power from within. The Protestants did not think that any priest or church could help them to acquire the certitudo salutis (the psychological certainty to be saved); not simple good works or institution- 
al grace with regard to sins committed did suffice any more, but one was required to conduct one's whole life in a systematic and methodical way. A revolution in mentality took place, as the Protestants took a stance against the enjoyment of life. Not economic but religious premia (the prospect of salvation) were expected by an ascetic life style and the rational tempering of the greed for gain in one's profession. Moeover, the organizational structure of the sects which augmented social control and compelled the members to prove themselves among their peers added to the inner motivation a further pressure from the outside.

The systematization of canon law, the new ideas in mercantile law, the feudal contract and the rise of the ideal of the citizen all added to the legalization of life ${ }^{89}$, and Weber did indeed write that the rationalization of law and the increasing calculability of the functioning of the legal process constituted one of the most important conditions for the existence of the capitalistic enterprise (ES: 883) - but by no means the only one. Only when in the sixteenth century the social form of the sect became dominant in parts of Western Europe and North America ${ }^{90}$ and when the Protestant ethic was added to the above-mentioned legal developments so that one can talk of a bourgeois conduct of life, different from the seigneurial-feudal conduct of life or the modes of conduct of peasants or the Faustian life of full and beautiful humanity, only then a development of «unbroken consistency» could set in which could take advantage of the legal ideas and institutions discussed earlier and would lead to modern capitalism. Thus, Weber could say that «in the last resort the factors which produced (modern) capitalism were the rational permanent enterprise, rational ac-

89 Even the relationship of man to God became a sort of legally definable relationship so that salvation could be settled by a legal process - a theory later developed by Anselm of Canterbury (ES: 553).

90 According to Troeltsch (1911), Christianity has created three social forms: the church, an organization administering the means of salvation; the voluntary sect of committed believers ; and mysticism which denies the validity of any social order or formation of the world. Weber accepted this classification of the three types of religious forms (ASS: 462 sqq). The existence of these three social forms was the consequence of the influence of Stoicism on early Christian thought, distinguishing the idea of a perfect natural law (the ideal of mankind ruled by reason, which led to the formation of sects) from relative natural law (which recognizes the diversity of status and the existence of irrational passion, as in the church), while mysticism denies any natural order on principle because of the meaninglessness of political and social life (predominant in Orthodox regions). 
counting, rational technology and rational law, but again not these alone. Necessary complementary factors were the rational spirit, the rationalization of the conduct of life in general, and a rationalistic economic ethic» (GEH: 354).

Of course, when Weber wrote at the beginning of the twentieth century, he thought that the spirit of religious asceticism had escaped from the «iron cage», and he saw only mechanized petrifaction and the «last men» in a godless and prophetless age.

\section{The Characteristics of Modern Western Capitalism}

The resulting modern Western capitalism can be characterized by three complexes of criteria:

1. The modern capitalist enterprise, based on

a) formally free and specialized labour, based on machine production

b) the legal separation from the household (including separate accounting procedures)

c) a disconnection of the capital of the enterprise from the wealth of the individual owners (possibility of joint stock companies)

d) freedom of contract

2. A capitalist economic order, including

a) the openness of the markets for labour, capital and land

b) a formally rational and predictable legal system and public administration

c) the modern state (Anstaltsstaat)

d) rational technology

Weber considered these two complexes of critera as the conditions for obtaining a maximum of formal rationality of capital accounting (ES: 161/2). To this, however, must be added

3. The spirit of capitalism - a rationally moderated pursuit of profit for the purpose of proving oneself in one's vocation.

The causal connexion between religious ethics and capitalism will be further analysed in Chapter IV and the connexions between different kinds of legal systems and capitalism in Chapter V. 


\section{CHAPTER IV THE WORLD RELIGIONS IN CONTROL TESTS}

\section{Basic Literature:}

Weber, Max (2012) «Critical Studies in the Logic of the Cultural Sciences» part II in: Collected Methodological Writings London: Routledge pp 169-184

Kries, J. v. (1888) Über den Begriff der objektiven Möglichkeit Leipzig: Fues’s

\section{Elective Affinity and Causal Adequacy}

When Max Weber wrote his essays on the «Economic Ethics of World Religions» and when he planned additional essays on Islam, early Christianity and Orthodox Christianity, he thought that capitalism in a general sense has existed in most advanced cultures. Certainly, when he talked of capitalism Weber did not mean the uncontrolled impulse to acquisition, the simple pursuit of gain or of money, for this pursuit has been common at all times and in most countries among coachmen, dishonest officials, crusaders and waiters, and, as Weber said, this naïve idea of capitalism should be given up once and for all. By capitalism in a general sense Weber meant the pursuit of profit by means of continuous rational enterprise and by formally peaceful exchange ( PE: XXXII) ${ }^{91}$ which can exist among traders and moneylenders and can also take the form of political capitalism, for instance in colonial capitalism or tax-farming.

While being well aware of these different manifestations of capitalism in Western history as well as elsewhere, Weber was mainly interested in the particular kind of capitalism which developed in Western society in the last several centuries: modern Western capitalism. He described it as rational-capitalistic organization of formally free labour, based on free market exchange and on the separation of business from the household, for the satisfaction of the needs of the masses ( PE: XXXV). Within this system may be found - at least at the time of its early development - the

91 A more complete definition would distinguish between the capitalistic enterprise and the capitalistic system which can only develop under the rule of law and when the administration of the monetary system has been monopolized by the State. 
«spirit of capitalism», identified with the rational tempering of the irrational impulse of gain, based on calculations in terms of capital and resulting from the religious doctrine of proof (Bewährung). In his Protestant Ethic (PE) Weber mainly, although not exclusively, tried to understand (verstehen) this «spirit» of capitalism, a certain style and conduct of life which a century or two after the Reformation appeared to have a close elective affinity with the religiously oriented ethical rationalism of the Protestants.

Most present-day scholars of Weber's PE see the relationship between the Protestant ethic and the spirit of capitalism as one of elective affinity or of homologic structures and not of causality ${ }^{92}$. The theorem of elective affinity (Wahlverwandtschaft) originated in the natural sciences: The Swede Torbern Bergmann wrote Disquisitio de attractionibus electivis in 1782 , referring to the fact that in anorganic chemistry elements may form combinations which can later be dissolved in favour of others. The German poet J. W. Goethe, who had his own view of the natural sciences, interpreted these phenomena of natural law described by Bergmann as resulting from inclination, affection or attraction, and he transferred these ideas and the German term which described them (Wahlverwandtschaft) to the realm of interhuman relationships. ${ }^{93}$ Goethe's figurative use of the term was later adopted by Weber in two different contexts and he attached to it two different meanings. On the one hand, Weber used the term to indicate meaningful adequacy (Sinnadäquanz) or affinity of meaning of religious concepts and motives in relation to each other and in relation to the total construct of meaning to which they belong. For instance, ethical (emissary) prophecy had, according to him, a profound elective affinity to the conception of a transcendent personal God ( FMW:285), the dogma of predestination combined with the doctrine of proof had an elective affinity with a systematic conduct of life as opposed to single good deeds, and the Protestant feeling of being a tool and not a vessel of God fitted well into the whole monotheistic world view although no causal relationships are implied here. Similarly, the devout Hindu was accursed to remain within the structure (Gehäuse) of the karma doctrine ( RI:121) which formed a

92 E. Fischoff (1968) «The Protestant Ethic and the Spirit of Capitalism: The History of a Controversy» in:S. N. Eisenstadt (ed.) The Protestant Ethic and Modernization New York: Basic Books 1968, p. 81

93 See Benno von Wiese's Editorial Note on Goethe's novel «Die Wahlverwandtschaften» in GoethesWerke, Hamburger Ausgabe, Vol VI, 1989, p. 675 
meaningful whole resulting from the non-causal elective affinities of its parts. Elective affinity here points to an inner consistency of thought configurations as they develop in the theologies of major world religions, resulting from the fact often observed in the history of ideas that what is rational or logically consistent has some degree of «power» over humans and thereby tends to favor a coherent thought structure.

On the other hand, Weber wished to place his methodology beyond the one-sided alternatives of materialism and idealism so that when he spoke, for instance, of an elective affinity between the spirit and the form or system of capitalism ( AC: 75) or between Calvinism and capitalism (ibid.: 107), he wanted to reject any type of reductionism and generalization about causality between religion and economy and he also wished to imply that any assertion about the manner and the general direction of causal relationships, while not excluding reciprocal influences, must be the result of further historical research, not just a methodological one. At the same time, Weber suggested that the elective affinity of the spirit of capitalism with its social structure, or form, can produce a mutually favorable relationship or even a reciprocal intensification (Steigerung) and a development of unbroken uniformity. In this case, spirit and form do not stand in each other's way, as would be the case if capitalism were imposed on a social environment which contains a different spirit.

It is in this second sense which does not exclude causal relationships if they can be established by historical research that Weber used the term Wahlverwandtschaft in the PE. He knew that for the historian the method of verstehen provides no guarantee of empirical truth, if it is not complemented by a method which can establish causal relationships.

It may be useful here to refer briefly to Weber's methodology which has as a starting point the logical distinction between natural science and cultural science. As a cultural scientist Weber was concerned with the interpretative understanding (verstehen) of social phenomena. Religions, he thought, provide human actors with categories and with an intelligible context of meaning which can be ideal-typically reconstructed (as Weber did with regard to the meaning contexts provided by the world religions). Scholars are then able to understand social actions which are related to such ideal-typical meaning contexts and which are in this sense rational and adequate on the level of meaning. In fact, such rationally interpretable meaningful behaviour often constitutes the most appropriate ideal-type for sociological analysis, for it permits to become aware of irrational or emotional influences. Such understanding is, according to Weber's interpreter 
Henrich ${ }^{94}$, the result of the anthropological characteristic of human beings to take position in relation to meaning contexts.

But understanding on the level of meaning is never sufficient, it must be verified by causal adequacy. Weber stressed the complementarity of verstehen (understanding) and causal explanation (CMW: 273/4), the necessity to control any interpretation by the methods of causal imputation if it wants to be more than a plausible hypothesis; in fact, sociology is concerned with the understanding of social action and thereby with a causal explanation of its course and consequences (ES: 4), as subjective meaning, understandable by the observer, is often but one element in the causal process.

The essays on «The Economic Ethics of World Religions» (EEWR) were used by Weber as control tests to establish the causal adequacy of religion and thus of the validity of his PE thesis, and they could possibly also have been used to establish the validity of the projected thesis of his planned essay on Occidental Christianity. While Weber's wife Marianne ${ }^{95}$ wrote that the essays on the EEWR contribute to the characterization of Western man and his culture, and while it may also be true that before the publication of his essays on India and China there lay Weber's discovery, as Schluchter ${ }^{96}$ puts it, that the whole of Western culture - not only its economic aspects, but also its law, its organizational aspects and even its music - is permeated by a specific mode of rationalism which needed to be characterized further by contrasting it with the different modes of rationalism in non-Western cultures, it should nevertheless not be forgotten that these essays also constituted an attempt to verify and to validate the PEthesis within the context of a universal history of capitalism. In fact, it was one of Weber's main historical and sociological interests, particularly in his studies on the «Economic Ethics of World Religions», to establish the cause or the causes of those particular aspects of modern Western capitalism which distinguish it from all other forms and manifestations of capitalism.

As Weber talked of the causal imputation of the "spirit» of modern Western capitalism to the religious ethic of Protestantism, or more generally of the attribution of a concrete effect to a concrete cause, it may not

94 D. Henrich 1952: 50

95 Marianne Weber 1975, Max Weber. A Biography. New York: John Wiley, p. 333

96 Wolfgang Schluchter 1989 Rationalism, Religion and Domination. University of California Press p. 45 
be superfluous to ask ourselves how he thought to achieve this causal imputation and what he meant by the terms cause or causation in a socio-historical context. For an answer, we shall go back to the work of the «outstanding physiologist» v. Kries ${ }^{97}$ on which Weber heavily relied ${ }^{98}$ and then to the essays on «The Economic Ethics of World Religions» which can serve to apply v. Kries' theory.

\section{Adequate Causation according to v. Kries}

It is an axiom, said v. Kries, that every event which actually occurs, was necessarily produced by the totality of all previously existing circumstances many of which are often unknown to us. But if this is so, what do we mean when we attribute a concrete event to a single cause? In order to show this, we must first clarify the notion of objective possibility.

If we say that an event is objectively possible, we mean that we are uncertain about its occurrence or non-occurrence because we do not know all its conditions and all the surrounding circumstances, for under clearly defined conditions the notion of objective possibility cannot be applied. But the same notion imposes itself when the conditions and circumstances of an event are only partially or generally known and when we wish to consider the relationship of an effect to these general or partial conditions. For instance, it is indeed objectively possible that, while playing at dice, the six comes up ten times in a row, for there is nothing in the general conditions and circumstances of playing at dice which might necessarily prevent this particular outcome. But it is also objectively possible that the six never comes up. ${ }^{99}$

We also say occasionally that a certain person could have done or known this or that. In such cases we abstract from the given particular thoughts and preoccupations which existed at the time of the event in question, as well as from the psychological make-up of the person under consideration, and refer only to that part of the circumstances which is of particular interest to us, namely the physical or intellectual capacities or the social position of that person. We thus assert the compatibility of a

97 J. von Kries 1888 Über den Begriff der objektiven Möglichkeit. Leipzig : Fues 's

98 Max Weber «Critical Studies in the Logic of the Cultural Sciences» in : CMW, p. 171

99 von Kries 1888 : p. 5 
certain action with a part of the total conditions involved. It might be argued, for instance, that Chamberlain could have stopped Hitler by not accepting the Munich agreement, if one abstracts from the political situation in Europe at the time and from his personal characteristics and refers only to his position as prime minister of Britain. On the whole, therefore, we may talk of the objective possibility of an event under generally or partially defined conditions, if such determinations of the conditions are conceivable which would, according to our experience and nomological knowledge, produce the event.

This notion of objective possibility will now be used in the context of causal relationships. Without any doubt, only the total complex of all conditions which produced a result may be called its cause in the strict sense of the term. But sometimes another sense of the terms cause and causation plays an important role, and this was particularly so in German legal thought which in Weber's time was much concerned with the problem of causality. We might say, for instance, that certain generally defined conditions or circumstances represent a larger or smaller possibility of bringing about a given result (e.g.: driving under the influence of alcohol increases the possibility of an accident). The question is, then, how such general statements about causal relationships might influence the evaluation of concrete cases. ${ }^{100}$

Before we return to this question, some preliminary remarks are necessary. According to v. Kries, the question regarding the causality of a certain circumstance or factor is equivalent to the question of what would have happened in a particular case if from the total context of conditions this circumstance or factor had been absent while all others had remained unchanged. Therefore, we shall say that a circumstance may be considered to have caused an effect if it can be shown that the same effect would probably not have occurred without it. But what do we mean when we talk about the same effect?

To be sure, we deny the causality of any factor not only if without it the effect would have occurred in the same way, but also if its absence would have produced only an unimportant modification of the effect. It is clear, therefore, that we are not interested in the effect with all its concrete details, but rather in a generalized idea of it. For instance, if we ask whether a certain medication has caused somebody's death, we want to know 
whether he would also have died without taking this medication but not whether he would have died in exactly the same position or in the same corner of his room.

Finally, the following distinction needs to be made: if a given factor has caused an effect, the causal nexus may be either general or a peculiarity of the given case. The following example taken from v. Kries will clarify this.

If a coachman who is driving a passenger is drunk or falls asleep and thus misses his way, and if then the passenger is killed by lightning, it may be said that the sleep (or drunkenness) of the coachman has caused the death of the passenger. For if the coach had been on the right way, it would without a doubt have been at a different location at the time of the thunderstorm and the passenger would probably not have been hurt. But one can perhaps say that there is here no general connection between the above-mentioned cause and the effect in all cases of drunkenness, although a causal connection is undeniable in this particular case. Moreover, in general, a traveller can also be hit by lightning, if the coachman is awake. ${ }^{101}$

Matters are quite different if, in the same example, instead of being hit by lightning, the coach had been overturned and the traveller had in this way been hurt or killed. In this case one would have to assume not only an individual but a general causal relationship between the sleeping of the coachman and the accident; one might say that in our experience the sleeping of a coachman, although it does not necessarily always cause an accident, generally does increase the possibility and probability of an accident. ${ }^{102}$

The purpose of these reflections will become clear with the help of the notion of objective possibility as it permits a general or abstract consideration of a causal relationship between a single factor and an effect. A theory which knows of no other causal relationship than that $\mathrm{B}$ always is the effect of $A$ and which thus asserts the regularity of an effect without any exception, often appears to be fruitless, for the relationship between a single factor and an effect often is not of such nature. But, as opposed to a causal theory which assumes an absolute regularity of the causal relationship, it is often possible to say that a causal element augments the objec-

101 Ibid.: p. $25 / 26$

102 Ibid. :p. 26 
tive possibility of an effect or that the presence of a causal element produces a certain effect in a much larger variety of circumstances.

In order to have short terms to designate the two variations in the example of the sleeping coachman, v. Kries talks of adequate and of «chance» causation. A is called the adequate cause of $\mathrm{B}$, and $\mathrm{B}$ the adequate effect of A, if generally (in the large majority of possible circumstances) A may be seen to favour B; in the opposite case he talks of «chance» causation. In the above example the drunkenness of the coachman was the «chance» cause of the effect that the traveller was killed by lightning; it would, however, have to be considered as the adequate cause in the modified example where the overturn of the coach resulted in the death of the traveller. ${ }^{103}$

It is perhaps useful to point to a frequently occurring confusion which tends to result from the misunderstanding of the fact that there is a basic difference between an event which is considered to be the «chance» cause of an effect and an insignificant event. Weber (CMW: 179) used the example of the two shots fired in Berlin in March 1848 which were, according to him, causally insignificant. One would speak of «chance» causation and impute the March Revolution to those two shots only if it could be argued convincingly that without them the social and political circumstances would not have produced a revolution. In fact, though, it is only conceivable that the two shots have had an influence on the precise moment of the outbreak.

It must be stressed that the distinction between an adequate cause and a «chance» cause does not refer to the manner in which in a concrete case a causal factor produces an effect, but that it has an abstract meaning. It is assumed that the causal factor is a behaviour or an event which can be added in the scientist's mind to a manifold variety of circumstances. Equally, the effect which may or may not have been favoured by the cause, remains generally defined and not described in all its details. The distinction between adequate and «chance» causation is always based on a generalized consideration of a particular case, the result of mental manipulations and comparisons, by which the degree of objective possibility is intended to be grasped, not, however, on the objective causality of the events. ${ }^{104}$

103 Ibid. : p. 27

104 Ibid. : p. 27 
It should also be noted that in v. Kries' theory of causality, which, as has been seen, is based on the notion of objective possibility, a clear dividing line between adequate and «chance» causality cannot be drawn. The steady transition follows from the fact that the general causal conditions for any effect may take any value between 0 and 1 . If, for instance, a train accident forces a traveller to spend a few hours at an unexpected location where he catches an infectious disease and dies, we might say that the train accident was a chance cause of his death. We would, however, be inclined to consider the death to be slightly more adequately caused, if the accident had happened in an area which is known to be disease-ridden. In fact, in this particular case the increase in the risk may be great though the resultant probability is still small. It should perhaps be mentioned in passing here that, as Hart \& Honore have noted ${ }^{105}$, there is a standing danger of confusion, if adequacy theory is misunderstood, between the notion of a substantial increase of a risk and that of increasing the risk to a substantial one.

If one wanted to characterize the theory of adequate causation, one would have to view it at some distance from many modern scientific outlooks. Platonic thinking is nowadays rather rare, and yet one misunderstands the term "adequate causation» if one thinks of it in any but a Platonic sense - i.e. that «true» adequate causation is an ideal to which real life situations approximate more or less. Weber (CMW:180) said that it admits gradations but that one cannot arrive at numerical estimates. When Turner \& Factor ${ }^{106}$ who have tried to fit adequate causation theory into the Procrustean bed of modern probability theory criticize the concept by suggesting that its only requirement for a claim of causal connection was a plausible claim of a relationship of conditionality and a dependent probability of greater than zero - and that it is difficult to see what «proof»» means here, they think in the more modern terms of true/false which apply to propositions, rather than in the terms of less true/more true which apply to types or ideal types of reality itself.

The distinction between an adequate cause and a «chance» cause can, according to v. Kries, easily be used in criminal law where it has to be decided whether someone is responsible for a criminal act. Our sense of jus-

105 Hart, H. L. A. and Honoré, T. 1985 Causation in the Law Oxford : Clarendon p. 493

106 Turner, S. and Factor, R. 1981 «Objective Possibility and Adequate Causation in Weber's Methodological Writings» Sociological Review 29 (1) p. 25 
tice seems to suggest that a person is responsible only for the adequate consequences of his actions. If, for instance, someone who in a street fight was slightly injured by a knife later died of tetanus, one would normally say that the fight was the «chance» cause and not the adequate cause of his death, because in general experience superficial knife wounds do not result in death. In a legal system which accepts the notion of adequate causation, the opponent would then not be held responsible for the death.

\section{Weber's Use of the Concept of Adequate Causation}

Max Weber had been trained as a lawyer and was quite familiar with legal theory. Having seen the fruitfulness of v. Kries' work in German legal theory, especially in the work of Gustav Radbruch, he applied it to the historical and cultural sciences. Like v. Kries, Weber thought that reality is a «heterogeneous continuum», a stream of immeasurable events which, because of the interdependence of all events, is infinitely complex. But scientific investigation can only grasp a finite and ever changing portion of this infinite reality and of the causal connections within it by concentrating on those aspects which acquire meaning and cultural significance for us or for the historian, i.e., which become «historical individuals». Weber went beyond v. Kries in concentrating on those aspects of «the infinite web of reality» which acquire meaning and cultural significance for us, i.e., which become «historical individuals», and then in perceiving these historical individuals as genetic ideal types which the scientist constructs in order to clarify reality and in the expectation of a possible causal relationship, and which he then uses as hypotheses for causal imputations.

It seemed to Max Weber that - apart from the question of subjective guilt - the legal expert and the historian or social scientist ask exactly the same question: under what circumstances and in what sense can it be asserted that an event or a person has caused a certain effect - and therefore that the ideas developed by v. Kries can and should be applied to the study of universal history. Both the judge and the historian do not explain causally the total course of events as that would be impossible and meaningless. While the judge's deliberations take into account those components of the events which are pertinent for the subsumption under the legal norms, the historian is exclusively concerned with the causal explanation of those elements of the events in question which are of «general significance» and hence of historical interest (CMW: 173). 
The battle of Marathon serves as an example. By the end of the nineteenth century, the Greek victory in the battle of Marathon of $490 \mathrm{BC}$ between the Athenian army under Miltiades and the Persian army of King Darios the Great was considered to have been of such importance for the subsequent development not only of Greek culture but of Western culture in general that the Baron de Coubertin did not hesitate to add the Marathon run of approximately $42 \mathrm{~km}$ to the list of Olympic competitions, in memory of the Athenian soldier who had run the same distance from Marathon to Athens in order to announce the victory - and had then died of exhaustion. If the Persians had been victorious - so it was thought they would probably have imposed a theocratic regime in Greece as they had done in Israel and Egypt a few decades earlier; the providers of oracles and mystery cults would have dominated the polis, and Greek culture with its philosophy, tragedy, sculpture, etc., the seedbed of Western civilization, would never have blossomed. In Weber's formulation we attempt to grasp the real causal interconnection by constructing unreal ones. (CMW: 182)

In Weber's words, the battle «decided» between the independence of Greek culture and a Persian-dominated theocracy which, in the case of a Persian victory, would have been objectively possible (although we cannot state the degree, between 0 and 1 , of this objective possibility), for, according to our general knowledge of the Persians, the course of events would have been different in its general outlines and in those features the cultural values which depended on the Athenian victory - which are significant for Western man. (It should be added in passing that this is the reason why Western man, according to Weber, rates Marathon higher than a battle between two African tribes). Weber concludes that it is not the case that a Persian victory must have led to a quite different development of Hellenic culture - but a different development would have been the adequate effect of a Persian victory.

\section{Adequate Causation and "The Economic Ethics of World Religions»}

The notions of objective possibility and of adequate and «chance» causation are equally useful in the interpretation of Weber's investigation of the causes of the spirit of modern capitalism. The thesis of the causal relevance of the Protestant ethic meant for him that modern capitalism, with 
its unchanged general characteristics, and quite apart from all its concrete details, probably would not have appeared without this causal element.

This thesis, namely that the Protestant ethic is an adequate cause - and not simply a cause and definitely not the only cause and probably not even the only adequate cause and perhaps not the most important adequate cause - of the modern capitalist spirit, is at the centre of Weber's comparative sociology of religions. Within the field of the cultural sciences, according to Weber, we can only have knowledge of adequate causes, and to say that an event was necessarily caused by previous conditions, would be a pure a priori. A thesis about adequate causation presupposes, as has been shown, a judgement of objective possibility; in Weber's case it presupposes a judgement on what we can imagine to be the effect, according to the rules of experience, if in the total complex of the historical conditions of modern capitalism we assume the Protestant ethic to be either absent or modified. A judgement about what might have happened under different circumstances would at first sight perhaps be called irrational, but Weber does not simply rely on the imagination of what might have happened.

In order to be able to arrive at a reasoned judgement, Weber turns towards historical analogies of the most different time periods and cultural areas. Ideally he would like to find a historical course of events which coincides with the development towards modern capitalism in all economically relevant respects except for the Protestant ethic. Weber does not find this logical ideal but he can show that, in spite of conditions in India and especially China which were at times and as a rule favourable for the development of capitalism (high esteem for wealth, significant technological knowledge, wars between competing states, etc.), capitalism of the modern occidental kind was not born there (although political capitalism did exist), while in the occidental cultural area, wherever the Protestant ethic took root, modern capitalism developed, even sometimes under the most unfavourable and miserable conditions, for example among the Puritans of New England. Weber, therefore, draws the conclusion that the objective possibility of the independent emergence of modern capitalism, when the Protestant ethic is absent, must be considered as small, for, in the absence of this causal factor, the other existing conditions and circumstances lead us to expect a high degree of possibility of another development.

It is possible to go one step beyond this argument. Weber was not only able to show, by means of intercultural comparison that, when the Protestant ethic was absent, modern capitalism as a rule did not arise (although, 
obviously, it could be imported from outside), but he also indicated that similar rational-ethical influences among certain other sects in other cultural areas (e.g. some Russian Old-Believers and sects or the Jains and Vallabhacarins of India), although they did not produce capitalism of the modern Western kind, nevertheless resulted in economic rationalization and success (PE:145 fn 12;) compared with the surrounding population of the same cultural area. This seems to indicate an adequate causal relationship between the ethics of certain kinds of sects and a generalized concept of capitalism. It is the paradox of all rational-ethical asceticism - as can be seen in the history of many monasteries - that it itself produces the wealth which it rejects. Not only ascetic Protestantism but also certain other religious communities characterized by a religiously oriented asceticism and rationalism of the conduct of life have had a revolutionizing effect on economic activity and pushed it in the same direction - and the realization of this fact in turn strengthens the Protestant ethic thesis, if one wishes to interpret it not only as a thesis about elective affinity of meaning, as most scholars who know only the $P E$ and not the EEWR do, but also as a thesis about adequate causation. It is true, though, that the religious communities in question (some ascetic sects before the Reformation, some monastic orders, some Russian and Indian sects) have not been closely studied by Weber - with the partial exception perhaps of the Jains, about whom he wrote a few pages in his essay on India. The apparent positive relationship between religion and economic success in the case of the Vallabhacarins in India and of some Russian sects and Old Believers has been studied more recently. ${ }^{107}$

Some other possible explanations of the development of modern capitalism were rejected by Weber. Technical advances, for instance, can certainly favour capitalist growth, but historical experience teaches that they alone are not generally able to overcome traditionalism and to contribute to the formation of a new economic structure. In ancient Rome the capitalistic development was highest when the technological development had ended and the technical knowledge of the Chinese remained without practical applications (ASS: 451 and RC:243). Similarly, the increase of the reserves of precious metals can accelerate an already existing economic

107 Jürgen Lütt, «The Doctrine of the Vallabhacarya Sect and the Economic Performance of its Followers» International Sociology 2 (3) 1987; Andreas Buss «The Economic Ethics of Russian-Orthodox Christianity», Part $1 \& 2$ in : International Sociology 4 (3 and 4) 1989 
development, but historical experience (for instance in Ptolemaic Egypt) shows that precious metals alone do not create a new economic structure. It should also be remembered that after the discovery of America, the flow of gold and silver to Spain produced a recession and not an increase of capitalistic development (GEH:353). And, finally, the existence of rational law cannot generally, out of itself, change the prevailing circumstances in the direction of more modern capitalism. In Rome, for instance, the highest degree of rationality in the legal system was attained only after the conclusion of the capitalistic development. 108

Technical advances, precious metal-resources and rational law, therefore, although not irrelevant, cannot alone be held to be adequate causes of modern capitalism. Other possible causes mentioned by Weber, e.g. population increase, the development of autonomous cities or commercial routes, etc., would perhaps merit some consideration but have not been studied comparatively as causes of capitalism by Weber.

The low degree of the objective possibility of the independent development of modern capitalism without the Protestant ethic, the development of modern capitalism even under otherwise unfavourable circumstances where the Protestant ethic predominated, further the high degree of objective possibility of rational economic activity within the sphere of influence of rational-ethical sects in non-western cultural areas, and finally his rejection of other, though less investigated, possible causes of modern capitalism have led Weber to the conclusion that the causal influence of the Protestant ethic was very high (Weber AC:120), that it was the adequate cause of modern capitalism, although, obviously, it is never possible, in the historical imputation of an effect to a cause, to arrive at a numerical ratio.

It has thus perhaps been shown that «The Economic Ethics of World Religions» must not only be interpreted in relation to Weber's discovery of a specific mode of rationalism in Western culture, but also as the methodologically necessary consequence of his discovery in the PE that there is an elective affinity between certain aspects of Protestantism and the spirit of capitalism. In the EEWR Weber proceeded to establish a relationship of adequate causation - assuming the precise understanding of this delicate notion as formulated by v. Kries - between certain idealtypi-

108 Schelting, Alexander v., 1934, Max Webers Wissenschaftslehre Tübingen: Mohr (Siebeck) 1934, p 113 
cally refined phenomena, while in the PE he had, to a large extent, only established elective affinity. Weber had perhaps referred to a yet undefined plan of this kind in the sibylline remark, made in 1908 in response to one of his critics, that the Gegenprobe of his PE, although promised, was still lacking. ${ }^{109}$

The interpretation of the term Gegenprobe, apparently used by Weber only once, is not without difficulties, but it probably refers to what in the older anglosaxon literature on Weber is termed «control-test» and what the French interpreters call, much more clearly, «validation causale indirecte» ${ }^{110}$ or «l'expérimentation causale par comparaison historique» (Raymond Aron ${ }^{111}$ ).

This leads to a final point. When H. Tyrell ${ }^{112}$ sums up the premises and intentions of the PE-essay and then declares that Weber never plausibly or systematically explicated the power and efficacy of religion which he rather took, in the wake of Nietzsche, to be self-evident, he simply ignores all the Gegenproben of the EEWR which Weber had undertaken in his later years. By revealing relationships of adequate causation, Weber indeed also established the efficacy of religion, at least the «adequate» efficacy.

109 Max Weber Kritiken und Antikritiken. Die protestantische Ethik II (edited by J. Winckelmann) Gütersloh: Mohn 1978 p. 54. The term Gegenprobe is found in a footnote and refers to Weber's statement that he had promised further studies as supplements, interpretations and further testing of his PE thesis (AC : 45). Recent translations as «converse causal relationship» (AC:49) or simply as «counterargument» ( The Protestant Ethic and the «Spirit» of Capitalism and Other Writings, P. Baehr \& G. Wells ed. and transl.) London : Penguin 2002, p. 240 ) do not seem quite adequate.

110 Philippe Besnard Protestantisme et Capitalisme Paris: Armand Colin 1970, p. 19

111 Raymond Aron 1967, p. 543

112 H. Tyrell, 1990, «Worum geht es in der 〈Protestantischen Ethik»?» Saeculum, vol 41 , no. 2,130 sqq. 


\title{
CHAPTER V THE WORLD RELIGIONS AND THE LAW
}

\author{
SECTION 1: MAX WEBER'S SOCIOLOGY OF LAW
}

\section{Basic Literature:}

Weber, Max (2012) «R. Stammler's 〈overcoming the materialist conception of history» in: Collected Methodological Writings London: Routledge pp 185-226

Weber, Max (1968) Economy and Society Chapter VIII (pp 635-900) New York: Bedminster

As Max Weber had not been given the time to complete his tour of the world religions and then to address the characterization of Western Christianity and culture in a final and concluding essay, our understanding of this characterization is limited to the dispersed remarks in Economy and Society and, of course, to The Protestant Ethic. It can be asked, though, what he might have written, and there are good reasons to suggest that he would probably have given particular attention to the singular development of Western law in comparison with the laws of other religious and cultural traditions. This development was the result of the separation of law and religion since the so-called Papal revolution.

Max Weber's sociology of law belongs to the least accessible and the least known parts of his oeuvre, particularly in the English speaking world. But, although he is today considered as one of the fathers of classical sociology, as a student he studied law and he wrote his two doctoral theses on questions of commercial law in the Middle Ages (1889) ${ }^{113}$ and on the relationship between the law and the agrarian situation towards the end of the Roman Empire (1892) ${ }^{114}$. Besides these texts, there are also the two texts in Weber's Economy and Society: The chapter on the «Sociology of Law» in volume 2, and the text in volume 1 under the title «The Econo-

113 The History of Commercial Partnerships in the Middle Ages (transl. by L. Kaelber) 2003

114 The revised and enlarged version of 1909 was translated as The Agrarian Sociology of Ancient Civilization London, New Left Books 1976. It is the first major comparative work of Weber, treating Mesopotamia. Egypt, Israel, Greece, Hellenism and Rome. 
my and the Social Norms». Both these texts were originally translated into English and published together by Max Rheinstein under the title Max Weber on Law in Economy and Society (Harvard U. Press 1954) and then later as parts of Economy and Society. It should be noted, however, that the text which both in the German version and in the English translation was previously called «Sociology of Law» has now (in MWG I /22-3) acquired the title «The developmental conditions of the law» (Die Entwicklungsbedingungen des Rechts), pointing to the possibility that it may perhaps not be interpreted as a sociological text at all, but rather as a universal history of law. Moreover, there are many comments and remarks on the law in other cultures or civilizations in Weber's essays on the various world religions and in his General Economic History (which, however, is merely a reproduction of course notes of Weber's students). Finally, there is the long article on «Stammler's «Overcoming» of the Materialist Conception of History» which will be considered shortly. Weber's study on Stammler will serve as the point of departure, for it is here that Weber tried to clarify his distinction between the law as a system of norms (the object of jurisprudence) and the law as an empirical order (the point of view of the sociology of law) - a distinction which is perhaps easier to make in the context of the European civil law tradition than with regard to the common law of England or North America.

\section{Jurisprudence and the Sociology of Law}

Legal rules may be studied from several different points of view. They may for instance be considered as norms or as facts. Max Weber uses the following example ${ }^{115}$ : If I say that my digestion is regular, I may be stating the simple fact of nature that my digestion follows a certain temporal pattern. In this case, the norm is an abstraction of the regular natural process. But I can also come to feel the need to «regulate» my digestion by eliminating some disturbances, and then the norm becomes an ideal which one desires nature to conform to. The observed reality and the desired ideal may sometimes coincide, but conceptually they are different.

115 "R. Stammler's «overcoming» of the materialist conception of history" in: Max Weber: Collected Methodological Writings. (ed. H. H. Bruun \& S. Whimster, London: Routedge 2012) p. 207 
Before entering the sphere of law Weber tried to clarify the distinction between jurisprudence and the empirical or sociological analysis of law by an analysis of «the rules of the game». While he took as an example a game relatively little know outside Germany, the skat (ibid., p. 212 sqq.), it may be useful here to analyse a better know game, the football, in Weberian terms.

The rules of football are valid in the same way for the players as the rules of law are valid for the citizens of a state. The players accept these rules which determine how one should play correctly and who should be considered as a winner. If one wants, one can propose changes to these rules by addressing oneself to the International Football Association, perhaps in order to discuss the disastrous effect of the offside rule on teams which prefer an aggressive game, or in order to question the rule that the referee always has the last word. These are questions related to the politics of football. But as long as the rules are considered valid and in force, there are only questions of jurisprudence and questions of the interpretation of the rules, e.g., whether a given rule should be applied in the situation $\mathrm{x}$ or $\mathrm{y}$ or how the referee should decide if he wants to decide correctly. These are dogmatic questions.

The situation is completely different if one wants to explain a concrete football game. The rules of football are certainly a precondition of every game, although not the rules as interpreted by the jurists of football, but rather as conceptions or ideas which the players have of their content and of their importance. Weber calls these the maxims of the players. Moreover, the ideas which the players have of the rules are only one factor among others which influence their action. Other factors could be: their physical and psychological condition, their motivation, their level of intelligence and their fair play.

Finally, the rules of football are a precondition of what one might call the empirical knowledge of football, providing to those who are not familiar with the game the capacity to distinguish it from a game of rugby or field hockey. For those who are unfamiliar with football see only a bunch of adult men running here and there, pushing and shoving, and efforts to kick a ball in all directions. But if the observer has the impression that there is a certain probability or a chance that the actions of most players are influenced - at least to a certain degree and most of the time - by the rules of football, he will think that he actually sees a football game. 
Thus, one can distinguish three levels of analysis:

1. The ideal norm, analysed by the jurists of football;

2. The maxims of the players which contribute, together with other factors, to the empirical event;

3. The rules as a means of knowledge which serve to analyse the empirical facts; this analysis may be intended for classification, causal analysis or other purposes.

If the rules are considered as facts - the level of sociological analysis -, then Weber maintains that one cannot pass from these facts to values or norms; if, however, the rules are considered as norms, jurisprudence cannot demonstrate the necessity of the existence of these norms, it can only ascertain their validity according to the patterns of juridical thought processes. Passing from the analysis of the rules of football to an analysis of society, it may be said that any sociological analysis, for instance a study about the relationship between economy and law, cannot be concerned with the ideal normative order but only with its empirical validity or the extent of the probability that certain maxims contribute to certain legally acceptable actions.

Incidentally, the distinction between the sociological analysis and the doctrinal analysis reappears in Weber's essay on the Protestant Ethic. A superficial reading of it might lead to the belief that he attributed this ethic to the dogma of predestination as formulated by Calvin. But this is not the case, for the logical consequence of the dogma that God has predestined us to hell or paradise would be fatalism, as Weber admitted himself (PE: 192). The social result, however, was just the opposite because of the introduction of the idea of proof by Protestant ministers. The maxims of the Protestants and their comportment were formed under the influence of the psychological sanctions which the religious context as a whole (sermons, social pressure, and mainly the possibility of proving to oneself one's status of grace) placed on them.

The Rationalisation of the Societal Spheres

As already mentioned, Rheinstein's translation of Weber's sociology of law introduced it into the English-speaking world. In his introduction, Rheinstein informed his readers that Weber's main problem is the relationship between modern legal thought and modern capitalism, although 
he admitted that Weber never said so expressly. ${ }^{116}$ In the subsequent English literature on the subject, this opinion has been repeated like a mantra. ${ }^{117}$

The present analysis will disregard the idea that the relationship between law and economics constitutes Weber's main interest. It rather starts from the equally well-established position that Weber's research after the early publication of the Protestant Ethic centered on his idea that Western culture as a whole may be characterized by a process of rationalisation and that Weber wanted to retrace this particular process also in the field of law. It will be seen that this process of rationalisation had no necessary connection with other social spheres, for instance the economy, but that it followed, at least at the level of the ideal legal norms, its inner logic.

Hubert Treiber ${ }^{118}$ has suggested that Max Weber has described the process of the rationalisation of religion and of law in the Occident in very similar ways, although the rationalisation of religion has been described in more detailed fashion. Following Treiber's suggestion, the rationalisation of religion will here be used as a background for the analysis of the rationalisation of law.

The rationalisation of religion is defined by Weber by two related phenomena: systematisation and disenchantment. He wrote:

«For the level of rationalisation a religion represents we use two primary yardsticks which are in many ways interrelated. One is the degree to which the religion has divested itself of magic, the other is the degree to which it has systematically unified the relations between God and the world and therewith its own ethical relationship to the world.» (RC: 226)

In conformity with this definition Weber explored several ideal-typical levels of religious rationalisation. The world of magic was for him an «enchanted garden» with spirits and beliefs in animism. Demons could be pacified and even dominated by magical acts. But there was no separation between this world and the «other world». The cosmos was monistic. Upon the arrival of cults of salvation the division between human beings and

116 Max Rheinstein 1954, p. L

117 Kronman 1983; vide also Trubek (1972: 746) who advanced the opinion that according to Weber a greater rationalisation of law produces a greater calculability of economic action - but who then believed to discover that this hypothesis encounters a problem in the case of England.

118 Hubert Treiber «Elective Affinities Between Max Weber's Sociology of Religion and Sociology of Law» (1985) 14 Theory and Society, p. 809 sqq. 
that which was considered divine became more intense and the concept of god became more systematized. The gods became specialised and humans turned to them by means of sacrifices and prayers. The profession of priest came into existence, and these priests offered advice and became the specialists of the ceremonies of sacrifices and of prayers. They also received a specialised training. Ritual magic of the previous level was replaced by ethical commandments, pronounced by prophets. This led to a more methodical conduct of life. In opposing all casuistry, ethical prophecy led to practical rationality, for it systematised the norms and the style of life. The world was seen more and more as material which should be fashioned according to coherent interior norms. (RC: 235)

Finally, there were salvation religions with a now dualistic view of the world, assuming an abyss between this world and the world beyond. These religions completely systematised the concept of divinity and they completely eliminated all magic. In the Occident, this systematisation has been achieved by transcendental monotheism, while in the Orient one rather encounters cosmocentric concepts with an impersonal divinity.

The mention of different concepts of God or of the Divine leads to another way to conceive the rationalisation of religion. It is not about the level of rationalisation any more (from magic to salvation religions), but about different directions or orientations of rationalisation. One may encounter - in India or in Buddhism - a rationalisation of religious thought which produces an attitude of world rejection, or it might lead, as in Confucianism or Protestantism, to an attitude of world acceptance or even world domination. Moreover, to the different conceptions of the divine correspond different kinds of prophecies: exemplary prophecy which shows the path to salvation by personal example (Buddha or Gandhi), and emissary prophecy which requires obedience to ethical commandments (ancient Jewish prophets). In the Orient, the rationalisation of religious concepts leads humans to consider themselves as vessels filled by the divine presence, while in the Occident humans may see themselves as instruments used by a transcendent God to change the world. In the second case, the fundamental attitude is not contemplation but rather an ascetic life style, working within the orders of the world. A methodical conduct of life can thus result from different orientations of religious rationalisation. Be it world rejection as in Buddhism, world acceptance as in Confucianism, or world domination as in Calvinism, such an ethos is always the result of a set of ideas constructed as a rational and coherent whole. 
The different orientations of religious rationalisation are closely related to the problem of theodicy. In the Occident, this problem is: If there is a transcendent God who has absolute power, how can his existence be reconciled with the imperfection and the suffering in the world? Elsewhere, where there is no transcendent all-powerful God, the problem is different, but in any case Weber believed that, to the extent that the disenchantment of the world increases, it becomes more difficult to find a rational and coherent solution to the problem of theodicy and that humans are confronted by irruptions of the irrational (FMW: 281). Weber saw three rational solutions to the problem of theodicy: the karman doctrine of India, Zoroastrian dualism and the Protestant predestination - whereas all other solutions were considered by him as compromises.

Weber attached also great importance to the study of the carriers of religion: priests and prophets. While magicians, shamans or sorcerers received a mostly empirical and applied formation so that their thinking was stereotyped, priests underwent a more rational formation and could develop a more coherent system of ideas. In order for this to happen, the clergy needed to be organised in a way which was independent of political influence. This was not the case in Antiquity or in China, but Indian brahmins, belonging to a separate category of castes, were relatively independent. Independence of the Church and of the clergy also developed in the Occident since the Investiture Struggle.

Rational thought, developed by the clergy of an independent church, generally does not find its support among peasants who everywhere have to adapt to the force of nature and prefer to find support in magic, but rather among craftsmen in the cities who depend on rational planification of their work and also among the bourgeoisie and rational bureaucracies. Calvinism corresponded well to the expectations of citizens involved in trade and commerce. It provided a rational solution to the problem of theodicy by making God inaccessible to human understanding. The doctrine of predestination eliminated the usefulness of good works for salvation and made salvation by magic, sacrifices or sacraments impossible. No human aid to achieve salvation was possible, and a cold individualism descended on a society which rejected the traditional religious ideal of brotherliness. The only option which remained for the individual who wanted to make certain that he was among the elected, was a methodical and ascetic - and in this sense rational - conduct of life within society. This methodical ethic which wanted to transform the world for the glory of God had, according ot Weber, an elective affinity with the spirit of capitalism. An 
elective affinity, however, is different from a causal relationship. Weber did not say that the kind of rationalisation which was produced by Calvinism was the direct cause of capitalism.

«Not ideas, but material and ideal interests, directly govern men's conduct. Yet very frequently the «world images» that have been created by ideas have, like switchmen, determined the tracks along which action has been pushed by the dynamics of interests» (FMW: 280)

Religion is an independent sphere having its own dynamics and following its own process of rationalization. The more it is rationalized, the more it enters into a conflict with other spheres of social life. The tension between the religious sphere and the economic sphere may serve as an example.

The most primitive forms of magic manipulation of spirits or gods were aimed at health problems or related to the wish of descendents or wealth. A tension between economics and religion did not exist. This was the case in the old (Vedic) Indian, Chinese and Jewish religions. But, to the extent that religions proceeded on the path of rationalisation, their relationship with economic considerations became more strained. According to Weber, rational economic activity is impersonal and oriented towards profit on a market.. Without estimating a price in monetary terms, a calculation of profit is not possible. If the capitalistic activity follows its own inner laws, the relationship with religion which is oriented towards brotherliness and against the holding on to money and the taking of interest, becomes difficult.

Thus, there are two autonomous spheres, regulated by their own internal rationalisation, and a deep conflict develops between them. There are only two rational solutions to this tension: the Calvinist ethic which renounces brotherliness, and mysticism which escapes from the world. Tensions also develop between the religious and the political sphere. On the level of the magical world view this problem did not exist, but with the arrival of salvation religions and a god of love, an abyss opened up between these religions and the bureaucratic state which fulfills its functions objectively sine ira et studio (without hate or enthusiasm), which follows its own inner laws and can only appear as a caricature of ethics.

\section{Excursus on Eigengesetzlichkeit}

In the analysis of the tensions between the religious and the economic and political spheres, the terms «own laws» and «inner laws» have been used 
when reference was made to the evolution of these social spheres. The terms are approximate translations of a German term which may have been formulated by Weber himself ${ }^{119}$ and which has been translated into English (and other languages) in the most diverse and incoherent ways. A well-known collection of some of Weber's essays, for instance, uses the following translations: «internal and lawful autonomy (FMW: 328), «inherent logic» (FMW: 341), «own immanent laws» (FMW: 331) and «peculiarity of its technique» (FMW: 147). The reader does not easily realise that he is referred to a term of terminological precision and significance.

As Conrad has shown, Eigengesetzlichkeit does not mean autonomy in the sense of the freedom or right to establish or change one's own laws. It rather refers to the necessity and/or obligation to follow the logically deductible internal laws of a social sphere, be it religious, political or economic, or the subjection of a social sphere to its inner logic. Machiavelli has demonstrated it with regard to the political sphere, rational capitalism does it in the economic sphere. Everywhere, according to Weber, rational thought in the sense of a need of inner logical coherence has power over man. The various systems of thought confiscate the empirical experience and mould it in their own way. Rational coherence is an independent motive of human thought and activity, and Weber sometimes referred to it in order to overcome monocausal sociological explanations. The notion of Eigengesetzlichkeit which Weber had developed in the context of his sociology of religion then seeped into his sociology of law.

\section{The Rationalisation of the Law}

The term Eigengesetzlichkeit can indeed be found in the German version of Weber's sociology of law, but the English reader cannot easily recognize it for it is translated by «a high degree of independence» (ES: 650) and by «intrinsic necessity» (ES: 885) ${ }^{120}$. One needs to read the German

119 Dieter Conrad «Max Weber's Conception of Hindu Dharma as a Paradigm» in: D. Kantowsky (ed.) Recent Research on Max Weber's Studies of Hinduism. London: Weltforum 1986. Conrad suggested that Eigengesetzlichkeit may be a translation of the Indian term svadharma (the dharma of particular castes or a discipline imposed on one's group). Weber only used it after the completion of his research on India.

120 The corresponding German passages can be found in WG: 392 \& 506 . 
text in order to realize that Weber's concept has been obscured by the translation, a concept which Weber also hinted at when he wrote of «the intellectual needs of the legal theorists» (ES: 855) and of «the force of the purely logical legal doctrines» (ES: 789). In order to arrive at the stage where Eigengesetzlichkeit can develop, it was necessary that the law separated from religion and passed through several levels of progressive rationalisation. Just as in the case of religion, the rationalization of law can be characterized by disenchantment, generalization and systematization or, as Weber wrote, a body of law can be «rational» in several different senses: generalization (which often leads to casuistry), synthetic construction of «legal relations» and, in later stages, systematization (ES: 655).

Early law was irrational. There were trials by ordeal, magical concepts, oracles, and there was patriarchal authority within sibs and clans. A criminal act was a violation of a magical norm, i.e., a tabu, and the original procedure of mediation was determined by magical beliefs. Witnesses did not affirm that a «fact» was true, but confirmed the rightness of the party whom they assisted by exposing themselves to the divine wrath (ES: 811). Trials took place as forms of arbitration or conciliation between different groups or clans whereas within the clan the patriarch pronounced his decision according to customary law. The first rationalisation of customary law was the result of the delimitation of the powers of the patriarch by religious norms or by a political power above the clans. Where the clans remained strong, as in China, a rational law could not develop. At this level, there were no general norms but rather evaluations of each particular case, often related to the status of the person being judged as this determined the decision. In these cases Weber spoke of an irrational law from a substantive point of view and of qadi-justice. Surviving characteristics of this kind of law can be found even today, according to Weber, in "peoples' tribunals» as well as in the existence of lynching and of juries.

A certain formalisation has then been introduced by charismatic persons, for instance the Druids among the Gauls or the rachimburgi, charismatic «declarers» of the law, in German areas. Also, Roman law consultants offered advice (responsa) to judges, formulated as oracles. These law consultants were probably among the first legal professionals. The judges then formulated their sentence on the basis of a revelation or an oracle. This law was formal in the particular sense of an exterior formalism. In order to acquire something, for instance, one needed to touch it with one's hand (mancipatio). Weber wrote of an irrational law from a formal point of view when one applies in law making and law finding means which 
cannot be controlled by the intellect (ES: 656). Today, the oath is a remnant of this kind of law.

But the historical movement advanced from traditional law and charismatic law formulations to the creation of rational law. While in earlier times the law was revolutionized from time to time by prophets - the Decalogue or Koranic law come to mind - , law became more formalized since the arrival of salvation religion and particularly of Christianity, and the revolutionary powers then lay in the tension between the different orientations which this formalized law adopted. What contributed to the formalization of (Occidental) law was, on the one hand, the refusal of the Church to have any relations with the State, and, on the other hand, its great religious and intellectual influence which tended to eliminate magic and the power of the clans and had created a systematized belief system. Roman law had distinguished between fas (religious law) and ius (legal obligations), a distinction which facilitated the creation of a secular rational law by the law specialists in Byzantium and Italy. Only later did the Church, in a compromise with the secular powers, accept and adopt the natural law of the Stoics, «the sum total of all those norms which are valid independently of, and superior to, any positive law... and provide legitimation for the binding force of positive law» (ES: 867).

In order to eliminate the revolutionary tendencies which are immanent in all natural law, the Church adopted the Roman interpretation of natural law which distinguished between absolute and relative natural law, thus considering political subordination and even slavery as facts of life which one can soften but not eliminate. The adoption of natural law led also to to the reception of Roman law which in turn served as a basis of canon law. Canon law did not combine, as the sacred law of other cultures, secular elements with sacred law. In any case, the separation of secular law and the law of the Church, affirmed since Pope Gregory VII, strengthened the development of canon law and the development of the rational bureaucracy of the Church which, in order to impose discipline, needed rational legal procedures; it eliminated the ordeals and, during the Inquisition, even developed a certain concept of proof. By analysing this development Weber showed that the formal side of modern law in Europe had its origin in Roman law while its concepts are largely inventions of the Middle Ages or of even more recent origin (mortgages; company shares etc.).

In contrast to this formal rationalisation of canon law and of secular law, the rulers of the imperium, as Weber called the State of this period, often preferred a more substantive rationalisation which took account of 
the political and social necessities as well as of the material conditions and of any ethical concepts which purely formal rationality tends to ignore. But these exterior influences of the law were also systematized to the extent to which the centralized imperium developed a bureaucracy. Among the exterior ethical influences was the modern form of natural law (as opposed to the classical natural law which was the foundation of canon law): the idea that there are inviolable innate rights or natural human rights. This idea is the foundation of modern individualism and of the modern concept of the contract, the social contract as well as the contract between two individuals. The last (provisional) stage, however, was the formally rational law of the German Pandectists of the nineteenth century. On the whole, according to Weber,

«the formal qualities of the law emerge as follows: arising in primitive legal procedure from a combination of magically conditioned formalism and irrationality conditioned by revelation, they proceded to increasingly specialized juridical and logical rationality and systematization, passing through a stage of theocratically and patrimonially conditioned substantive and informal expediency. Finally they assume, at least from an external viewpoint, an increasingly logical sublimation and deductive rigor and develop an increasingly rational technique in procedure». (ES: 882).

This very short summary of Weber's very rich historical analyses may serve as the basis of a typology of law. Most commentators believe that Weber constructed a rather simple typology, based on two oppositions: 1 . Is the creation or the discovery of law rational or irrational? And 2. Is it rational or irrational from a substantive or a formal point of view? By combining the different possibilities, one arrives at four types of law:

a) Irrational law from a substantive point of view. In this case decisions are made on the basis of immediate feelings about a concrete case without recourse to general norms; no distinction is made between legal and extralegal criteria. This is a kind of traditional law, sometimes characterized by Weber as qadi-justice. (with reference to Muslim judges).

b) Irrational law from a formal point of view. Here the judge formalises his sentence, but he does it on the basis of means which are not controllable by reason: oracles, ordeals, responsa. Weber also refers to revealed law.

c) Rational law from a substantive point of view. This refers to the creation of legal rules which do not result from simple logical generalisation but which are based on extra-juridical norms such as a sacred 
book, an ideology ( such as the Soviet legal system) or utilitarian considerations.

d) Rational law from a formal point of view. The judge arrives at his decision by means of the internal juridical logic and on the basis of abstract rules within the systematized legal code.

Without doubt, these are ideal types which one encounters only rarely in their pure form, for reality is generally more complex. But these types have a heuristic value which permits to discern in which direction (e.g.: more formal or more substantive?) a given legal system orients itself. It is nevertheless surprising to what extent Weber's interpreters have disagreed in the application of these ideal types. English common law may serve as an example. Rossi ${ }^{121}$ affirmed that English common law is rational from a substantive point of view; Freund ${ }^{122}$, on the other hand, considered it formally rational; Rheinstein ${ }^{123}$ wrote that English common law approaches a law type which is irrational from a substantive point of view; and Kronman ${ }^{124}$ arrived at the conclusion that English comon law is mixed: it is rational if compared to oracles, but irrational if compared to the systematised law of the Pandectists.

But there are also those who seem to save the situation. Treiber and Rheinstein have suggested that Weber's typology does not contain four but rather five categories for, quite in conformity with Weber's text (ES: 657), they subdivide formally rational law into two subcategories: either the legally relevant characteristics are of a tangible nature and are perceptible as sense data (external characteristics of facts, e.g, the execution of a signature), or they derive from a logical analysis of their meaning when fixed legal concepts have been formulated. Thus, there may be formally rational law which is casuistic and another kind of formally rational law which is constructed as a legal system. Both these kinds of formally rational law (the «external characteristics» variety and the systematic abstraction variety) diverge from laws characterized by substantive rationality

121 Pietro Rossi «Die Rationalisierung des Rechts und ihre Beziehung zur Wirtschaft» in: M. Rehbinder \& K.P. Tieck (ed.)

Max Weber als Rechtssoziologe, Berlin: Duncker \& Humblot 1987, p. 52

122 Julien Freund «La rationalisation du droit selon Max Weber» Archives de philosophie du droit vol. 23 (1978), p. 69

123 M. Rheinstein Max Weber on Law in Economy and Society Harvard University Press 1954, p. L

124 A. Kronman Max Weber London: Edward Arnold 1983, p. 89 
(ES: 657). Indeed, Weber's typology of law can be systematized by the following diagram.

\begin{tabular}{|c|c|c|c|}
\hline & substantive & formal 1 & formal 2 \\
\hline rational & $\begin{array}{l}\text { norms drawn } \\
\text { from } \\
\text { outside the law; } \\
\text { holy book, ideol- } \\
\text { ogy }\end{array}$ & $\begin{array}{l}\text { general tangible } \\
\text { characteristics; } \\
\text { casuistic law; } \\
\text { English common } \\
\text { law }\end{array}$ & $\begin{array}{l}\text { norms obtained } \\
\text { by } \\
\text { logical analysis } \\
\text { within } \\
\text { a system of } \\
\text { thought: } \\
\text { Pandectists }\end{array}$ \\
\hline irrational & $\begin{array}{l}\text { evaluation with- } \\
\text { out } \\
\text { general norms; } \\
\text { qadi justice }\end{array}$ & \multicolumn{2}{|c|}{$\begin{array}{c}\text { formalisation which cannot } \\
\text { be controlled by reason; } \\
\text { e.g. ordeal }\end{array}$} \\
\hline
\end{tabular}

Even if one takes account of this more nuanced typology, it is necessary to add another precision which is tied to the difficulty of translating the German text into English. In the translation provided in Economy and Society (ES: 656) one finds the sentence «all formal law is, formally at least, relatively rational». But there are two different German words which have been translated by the English word «formal»: these words are 1) «formal» which may be translated by «characterized by the form or by formality», and 2) «formell» which might mean «in relation to the form or to formality». ${ }^{125}$ In fact, the German sentence in question does not only distinguish between the formal side and the substantive side of law, but it also asserts that the creation or the discovery of a legal system can be characterized by the aspect of the system which is emphasized. Thus, a given legal system can be considered as formal if the formal aspects are dominating the substantive aspects.

In this way Weber arrives at three distinctions: The first distinction opposes qadi-justice, based on the unique situation of an individual case, to judgments based on norms and general principles. This is the distinction between rational and irrational law. The second distinction opposes a law which separates legal and extra-legal norms, to a law which blends ethical and legal norms. This is the distinction between formal and substantive

125 The German text reads: «Formell mindestens relativ rational ist jedes formale Recht.»W.G. p. 326 
law. Finally, the third distinction opposes a law which attaches importance to empirical and tangible characteristics of factual situations, to another kind of law where juridical characteristics are underscored by logical interpretation within a legal system of thought. This is the opposition between two kinds of rationality within the realm of formal law.

Weber used this typology in order to answer the question as to why the purely logical construction of law was produced only in certain parts of the Occident, a logical construction which was the result of the transfer of Roman law into a new cultural environment. Weber described how Roman law was cleansed of all national characteristics and «elevated into the sphere of the logically abstract» (ES: 854), starting from the occasionally brilliant remarks of the Roman jurists and ending up in the creation of purely systematic categories such as «legal transaction» or «declaration of intention» and the proposition that what the jurist cannot conceive has no legal existence. Weber also showed that the consequences of purely logical constructions were often irrational with regard to the expectations of commercial interests and to the needs of ordinary life, and he particularly insisted on the fact that the internal rationalization of law, its Eigengesetzlichkeit, is always in conflict with those ideas which are related to substantive law and with non-juridical elements (ethical, religious or political) and which try to suggest solutions which appear more equitable or legitimate in a given historical context.

\section{The Carriers of the Rationalization of Law}

Among the phenomena which made the rationalization of law possible, there was writing and literacy. They made it possible to set down precedents and to reduce the irrational interpretation and decisions of legal questions. They also made it possible to produce codes like the Decalogue or the Twelve Tables, thus making the law more coherent. Just like the priests were the carriers of the rationalization of religion, legal experts were responsible for the rationalization of law.

«From a theoretical point of view, the general development of law and procedure may be viewed as passing through the following stages: first, charismatic legal revelation through «law prophets»; second, empirical creation and finding of law by legal honoratiores (cautelary jurisprudence and adherence to precedent); imposition of law by secular or theocratic powers; fourth and finally, systematic elaboration of law by persons who have received their legal training in a learned and formally logic manner.» (ES: 882) 
If one leaves aside the irrational charisma of legal prophets and the legal teaching in clerical schools which leads to a substantive rationalisation of law, it is possible to state that two kinds of juridical formation have shaped Western law. In England the teaching of law was traditionally offered by practicians, a technical training in the empirical sense of the term, while in Germany and France theoretical teaching was offered in the universities. English lawyers belonged to four inns of court and had to submit to strict corporate etiquette. Admission to the bar was a corporate monopoly. This was a craft-like specialization, based on a practically useful scheme of contracts and actions; no general concepts were formed by abstraction or by legal interpretation. In the purely empirical conduct of legal practice one moved from the particular to the particular and perhaps to analogies (ES: 787).

In continental Europe, because of the existence of a large number of princely courts and the decentralization of the administration of justice, a powerful guild or corporation of lawyers was not created. Lawyers received their education in universities. This was a learning of abstract norms of systematic character, stimulated by Roman law and removed from the daily needs of possible clients. The professors were theorists of law rather than practicians.

By opposing the English common law and the continental law Weber tried to show how the formal qualities of legal traditions can be influenced by the carriers of the law (Trägerschichten), i.e., by intrajuridical factors. On the European Continent the development of the law led to a logical systematization resulting from the intrinsic intellectual needs of the legal theorists formed in universities (ES: 855). In these intellectual needs of the doctors of law can be found the roots of the Eigengesetzlichkeit of continental European law.

Weber rejected the Marxist idea that the law is a reflection or the superstructure of the economy. No human activity and no sphere of social life, according to him, can be reduced to another. In other words, legal concepts are developed independently and may then sometimes be used in an economic context. Particularly in the Occident the law mostly resulted from interior conditions: the needs of the carriers of law as theorists and the political interests of the state which utilizes them. The theorists of law (priests, professors, legal advisors) and the political interests of the princes determined the orientation of the law (formal or substantive). It is also impossible to say, according to Weber, that the rationalisation of the law will 
necessarily lead to economic rationalisation ${ }^{126}$ and it is therefore not possible to agree with Rheinstein that in Weber's writings the categories of legal thought have «evidently» been conceived as parallels of the categories of economic behaviour. ${ }^{127}$ Rather, Weber tried to show that the forms of thinking have a greater significance and independence than what is ordinarily believed. One can only say that the economic structures offer sometimes a chance for the legal concepts to spread once they have been invented.

\section{The «England Problem»}

1. In general, the English literature on Weber's sociology of law has reacted rather negatively to Weber's classification and interpretation of the common law. Assuming that Weber wanted to study the relationship between law and economics (or between modern legal systems and capitalism), or the contribution of juridical ideas to the rise of capitalism, and in the conviction that one of capitalism's major geographic origins must certainly be found in England, anglo-saxon authors arrived at the conclusion that Weber considered the English common law as inferior to continental law or continental law as superior to English law and that this is a major difficulty for his theory. ${ }^{128}$ Berman bluntly stated that Weber's treatment of the English common law is ultimately flawed. ${ }^{129}$ They have overlooked Weber's comment that, wherever the two kinds of administration of justice and of legal training had the opportunity to compete with one another,

126 In this context Weber mentioned the amateurish notion of the litterateurs that Roman law promoted the development of capitalism, for the character of legal institutions of modern capitalism were completely unknown under Roman law and are of medieval origin (shares, bonds, bills of exchange etc.), and, moreover, Roman law never took roots in England (PW: 149, footnote).

127 Rheinstein 1954: LVIII

128 For instance Martin Albrow «Legal Positivism and Bourgeois Materialism: Max Weber's View of the Sociology of Law», (1975) 8 British Journal of Law and Society 14 -31, p. 22 and Bryan Turner For Max Weber; Essays on the Sociology of Fate. London: Routledge \& Kegan Paul 1981, p. 332

129 In: Stephen Turner The Cambridge Companion to Weber (2000: 230). It is perhaps noteworthy that continental writers do not seem to have addressed the socalled «England problem» at all. 
for instance in Canada, the common law has come out on top (ES: 892). Moreover, several general comments can be made in this context:

1. As has been shown in the preceding pages, Weber distinguished between two kinds of formally rational law, the English and the continental law, and also clearly stated that modern capitalism prospers equally and manifests essentially identical economic traits under legal systems which differ considerably from each other. (ES: 890)

2. Terms like rationalisation and formally rational law are ideal types and not ideals. That they are not ideals becomes clear if one remembers Weber's ambivalent attitude with regard to the rationalization of economic life, the «iron cage» which makes the soul wither away. As ideal types, on the other hand, they are heuristic concepts which accentuate unilaterally certain aspects of reality in order to make it appear coherent. In reality, however, both continental and common law contain aspects which may not be very formal and rational.

3. The critics who point to the «England Problem» neglect the distinction which Weber made between a legal order and empirical regularity, the law as a system of thought and the sociology of law. Rationalisation on the level of the law as a legal system does not necessarily imply a rationalisation on the level of empirical events or behaviour and, conversely, a rationalisation on the empirical level or of the maxims of the «players» does not necessarily lead to a more rational legal system. It is possible that this distinction between the sociological and the juridical point of view can more easily be made with regard to the continental law based on codes than with regard to the common law with its greater capacity to adapt to changing values and its closer relationship with substantive law. ${ }^{130}$ What Weber called the Eigengesetzlichkeit in the continental law systems would be much more difficult to find in the countries of the common law. This would also explain the explicit criticism of Albrow ${ }^{131}$ who believes that

130 Quite justifiably Michel Coutu (1995, p. 163) has complained that certain commentators, writing about the «England problem», did not sufficiently distinguish between the empirical and the dogmatic validity of legal propositions. He even suggests that the rationality on the level of legal dogma has no direct connection to empirical legal and rational economic behaviour (ibid. p. 152). The lack of a clear distinction between legal dogma and empirical behaviour might explain $\mathrm{H}$. Berman's and Charles Reid's surprising critique that Weber saw law, as he saw fortifications or a market, as a «fact» and that he failed to examine the values that are represented in law (Berman \& Reid 2000, p. 237).

131 Martin Albrow 1975, p. 27 
the distinction between the sociological and the juridical points of view is not well founded, and the implicit criticism of all those anglo-saxon authors (like Kronman) who simply ignore or neglect this contrast. The distinction between the two levels of the study of law makes also possible a comparison with a similar distinction in Weber's sociology of religion: the coherent and logical dogmatic teaching of the Calvinists was based on the ideas of a transcendent God and of predestination. But this dogma which logically would have led to fatalism does not explain the empirical economic behaviour of the Calvinists which was rather oriented by the idea of proof in the sermons and counselling of the Protestant ministers.

It is well known that according to Weber the capitalistic enterprise needs a calculable law on which it can rely «as if it were a machine». It needs a legal system which can guarantee contracts and investments, and this was particularly true in the early times of modern capitalism when the enterprise had to struggle against the hostility of previous kinds of law. What is less clear, however, is the meaning of the term «calculable law» in the discussions on the relationship between law and economy, for the notion of the predictability in law can have - as Coutu (1995) has alteady suggested - two meanings: 1 . On the systematic level it can refer to the possibility to deduct a juristic consequence of a given norm by logical manipulations; and 2. on the empirical level it may suggest an adequate relationship between a maxim of behaviour and real behaviour or a real judgement. The first level is the dogmatic level, the second is the sociological level to which one refers when one says that the capitalistic economy needs a calculable law. According to Weber, this kind of calculability is just as well achieved by the common law which is formal and empirical and tied to precedent as by the systematic and logically coherent law of the Continent (ES: 855).

In England and elsewhere the economy needs clearly defined legal concepts which only a formal law can provide. The concept of legal personality and all forms of limited liability which developed out of the commenda and the societas maris were useful in this context. But modern society is foremost an individualistic and contractual society. Weber discussed the freedom of contract in some detail. Before the rise of modern capitalism there existed mainly the status contract which led to a complete juridical modification of a person's social position and created a personal relationship (for instance the relationship between lord and vassal). This type of contract, according to Weber, was tied to magical and religious concepts: one felt dependent on a supernatural power which threatened 
those who acted contrary to the oath which concluded such a contract. The modern contract, on the other hand, called purposive contract by Weber, which in other times and places existed mainly to regulate relationships between clans or nations, became important after the decline of self-sufficient kin groups and the rise of the market economy. It contributes to the dissolution of traditional relationships between individuals and is based on impersonal relationships. It is of no importance whether modern contractual relationships are defined and supported by a formally systematic legal system or by the more empirical common law. Both types of law are part of an individualistic society which accepts the freedom of contract between individuals, and both are formal laws which guarantee the stability and predictability of procedure.

But there is a phenomenon in anglo-saxon countries which diminishes the formal character of the common law: the concept of reasonableness. Reason, which in the past was tied to religious concepts of an eternal order of nature, has turned into the «reasonable» adaptation to the laws of the country. According to Weber (ES: 870), the concept of «reasonable» contains the meaning of rational in the sense of practically useful, and it implies the idea that nature or reason do not want to lead to absurd consequences. These utilitarian ideas which clearly favorise commerce tend to show, according to Weber, that the common law is closer to the ideal type of substantive law than the continental civil law.

\section{Retrospective Considerations}

Modern law is separated from religion, but it has close ties with the political domain and the state. Substantively rational law has coexisted with the most diverse political structures: patrimonial kingdoms, the cities of the Middle Ages, the welfare state and the socialist state; it has also coexisted with the most diverse economic structures: non-capitalist economies, political, adventure, and colonial capitalism. Its principles may be diverse, but they have one characteristic in common: they are extra-juridical. This type of justice is rational in the sense of adherence to fixed substantive principles; its ideal type is the Solomonian judgement, or, as Weber wrote, Sancho Panza (in the novel Don Quixote) when he happened to be governor (ES: 845). English common law, although formally rational according to Weber, has a certain proximity to substantively rational law and has coexisted not only with modern capitalism in England, but also with adven- 
turer capitalism and political capitalism in the colonies. Formally rational law in the systematized continental sense, on the other hand, must be associated with the modern state and with modern rational capitalism. It was born since the systematizing efforts under the emperor Justinian in the sixth century, developed after the reception of Roman law in the Middle Ages and flourished in the code civil in France and the school of the Pandectists in Germany.

There is, however, in Weber's opinion a tension between the ideal of justice as it exists in substantively rational law, and the ideal of legal security and calculability of formally rational law, and this to the extent that, as formal rationalization increases, substantive irrationality also grows. ${ }^{132}$ Indeed, formal justice inevitably violates the ideals of substantive justice. There are efficiency, calculability and impersonality on the one hand, fraternity and personal relationships on the other, and Weber did not at all consider formal rational law in an optimistic way, but rather - to use a formulation of Julien Freund - as an expression of pessimism which organizes despair.

\section{SECTION 2: LAW IN THE WORLD RELIGIONS}

\section{Basic Literature:}

Weber, Max (1968) Economy and Society (Chapter VIII: sociology of law, pp 635-900) New York: Bedminster

Berman, Harold (1983) Law and Revolution Harvard University Press

What are the developmental conditions of the formally rational law of the Occident? Only a comparison with the laws of the other world religions

132 This has later been underscored by G. Radbruch (1980, p. 41), who had been a member of Weber's discussion circle in Heidelberg. He quoted from Bentham's panegyric about legal security: it makes foresight possible, the foundation of all planning, of all work and of all saving; it brings about that life is not only a sequence of events, but that it has continuity. But the tension between the ideal of justice and legal security (Rechtssicherheit) may lead, according to Radbruch, to a situation which can be characterized by the sentence summum ius summa iniuria (unconditionally and strictly applied law can in extreme cases lead to complete injustice). 
will render them visible. While in Western countries since the Middle Ages the sacred law is separated from secular law, so that the secular law and the juridical order can follow their own inner logic and systematization, supported by their own carrier strata, one finds in the context of the other world religions a conglomerate of mostly non-differentiated religious and legal prescriptions and therefore non-formal types of law, a nondifferentiation of administrative and legal procedures, and large areas of social life governed by customary law. These legal systems will be shortly considered here.

It should be clear that when we talk about the laws of the world religions, we do not consider complexes of ideas that are considered valid and can be analysed by legal scholars. Although such legal ideas may be important on another level, on the sociological level we are concerned with maxims which are adopted by legal actors and followed more or less consistently. As such they constitute a part of the exterior conditions which influence peoples' conduct of life and particularly their economic behaviour (as opposed to the interior conditions: the mentality or the spirit of the people). Weber also talked of the exterior form, as opposed to the interior spirit. ${ }^{133}$

133 W. Gephard believes that the talk about the law as a form makes no sense for there are levels of relevance of the influence of empirical legal orders (Gephard, W. Gesellschaftstheorie und Recht 1993, p. 503). Without a doubt, the empirical legal order is not a form in contrast to something else as a matter, as Weber himself wrote, but it is one of the external/exterior determinants of the behaviour of the acting human being (CMW : 220), in contrast to the «spirit» which motivates from the inside. With Kant, Weber thought that law is heteronomous and characterized by exterior force and constraints. It is true that Weber asked about the extent to which empirical legal orders are of causal importance for cultural phenomena and that he thought that for instance the facts that constitute the Sistine Madonna as a historical individual are irrelevant from a legal point of view (CMW : 221), but it remains that he considered empirical legal orders as relevant in regard to economic behaviour, even if it is true that not all the forms of social phenomena are as restraining as an iron-cage as it is possible to either adapt to it or to try to violate it. 


\section{The Laws in Non-Occidental Cultures}

China

In China there was no class of jurists nor any specific legal training. Chinese law did not arise from any religious revelation but rather from the code of conduct of a secular aristocracy. The high officials, the mandarins, had received a classical education and, to the extent to which they were involved in jurisdiction, they did not pronounce their decisions according to formal rules, but they took account of the concrete situtation and of the quality of the people before them. A specialised officialdom was lacking because of the magical idea according to which the virtue of the emperor and of the officials (their classical education and the performance of the prescibed ceremonies) keeps everything in order.

In a patrimonial state such as China the administration of justice can be rational in the sense of obeying firm principles, but this is not a rationality resulting from a formally precise and systematic construction of norms and thus is not calculable. It rather is of a substantive kind which is based on political or ethical principles. In fact, patrimonial law is imbued with substantive norms, and general administration and legal administration cannot be distinguished (ES: 844). Criteria of reasonableness, expediency and favor prevail, and Weber here used the concept of qadi-justice (RC: 102).

The power of the sibs in China was unbroken, and personal rather than formal legal relationships continued to dominate. The villages were largely self-administered according to local custom, based on the concept of piety (xiao) and with the help of informal dispute settlements within the sibs or clans. In fact, the clans were the most important source of private law and their agreement was often necessary in the case of a transfer of property. There was thus a relative absence of formal legal processes and the development of a private legal profession was discouraged as disruptive of the cosmic order. Moreover, among the ordinary Chinese there was a predisposition on grounds of expense, uncertainty and risk not to set off the rather brutal offical legal machinery. ${ }^{134}$

134 The relative absence of formal legal processes in traditional China was well described by Fei, Hsiao-tung in From the Soil. The Foundations of Chinese Society (transl. By G. Hamilton \& Wang Zheng, U. of California Press 1992). He described a society in which considerations of order, and not laws and individual 
The cities, because of the lack of the legal concept of corporation (RC: 91), were unable to show any autonomous legal development ${ }^{135}$. In official law, the cities existed only as organizations for enforcing the family liabilities for taxes and other charges (ES: 726). Commercial questions were hardly mentioned in the imperial codes and were mostly regulated by the associations of craftsmen and merchants. ${ }^{136}$ In case of arbitration, neither party might be granted an outright victory because of considerations of «face».

Formal calculable law did not exist, even with regard to property. Weber noted the possibility that a man who sold his house to another might return after some time and demand to be admitted as a non-paying tenant because he had since become poor (GEH: 342). Because of this lack of calculability Weber spoke of the irrationality of Chinese justice, related to patrimonial factors and the desire to preserve the honour and the «face» of all parties. On the whole, a rationally calculable functioning of administration and jurisdiction which is necessary for commercial capitalism did not exist, although politically determined capitalism quite often did flourish (RC: 103).

Even the Constitution of 1982 is different from the Occidental «rule of law» model; it does not assume that the State should control every activity and in this regard it is similar to the old Confucian division of legal activity between informal social justice and the official imperial code. Law is studied as a branch of administration and mediation and compromise are used by the state itself. 137

rights predominate - and where order means that each person must uphold the moral obligations of his ties with others. Ke ji fu li (subdue the self and follow the rites) is an old Chinese proverb, and Confucius wrote : what is necessary is to cause people to have no litigation (Analects, book 12, chapter 13). Fei further wrote that any litigation was considered shameful because it indicated a lack of proper education (ibid. 103), and the people who file cases in the courts of the modern judicial system are the same people recognized in the country side as being morally corrupt.

135 According to Karl Bünger, also the concept of limited company did not exist in China until quite recently because it limits the principle that debts must be paid. Even in modern times Chinese judges had difficulties with this concept.

(Karl Bünger «Das chinesische Rechtssystem und das Prinzip der Rechtsstaatlichkeit» in W. Schluchter, Max Webers Studie über Konfuzianismus und Taoismus Frankfurt a.M. 1983.)

136 S. van der Sprenkel, Legal Institutions in Manchu China. London 1977, p. 89

137 Vide Menski 2000 : 530 


\section{India}

Weber believed that in classical India all law was, according to Hindu doctrine, contained in the sacred books called the dharmasutras and dharmashastras, redacted by the priests (brahmins) ${ }^{138}$, whereas profane (customary) law was limited to the particular laws of certain professions and castes. These profane laws of the guilds and castes were not rationalized or systematized as they were not influenced by any intellectual or professional carriers (priests or others); in fact, there was no legal profession.

The means of coercion was the exclusion from the guild or caste. Proofs were sometimes formal, but irrational (magical ordeals), and often non-formal (hierocratically influenced). A disappointed creditor had magical procedures at his disposal: he would seat himself in front of the debtor's house and starve himself to death, thus compelling his sib to revenge him against the debtor. (ES: 678).

Because of the doctrine of karma (which derived one's place in the hierarchical system of castes from actions in previous lives), the juxtaposition of different ethics, even sharply contrasting with each other, did not pose a problem; moreover, society was ideally divided into four hereditary categories: the brahmins (priests), ksatriyas (political representatives), vaishyas (pursuing commerce and agriculture) and shudras (servants), each category having its own dharma (religious duty, obligation). The dharma of the ksatriyas, for instance, was quite Machiavellian: in the epic Mahabharata, Arjuna must kill his relatives in battle to fulfill his dharma.

But there was no place for the development of any kind of superior normative order, like the natural law concept in the Occident (RI: 144) which might have initiated a rationalization of the law ${ }^{139}$; there were diverse

138 These sacred «law books», concerned with the position of status groups and practical problems of life (ES: 792), did, however, not contain law in the modern Occidental sense of the term, but rather rules of guidance which were not binding and served as residual sources of law when no customary rules could be found. One might talk of a co-existence of local customary practice and the textual model. In the Manavadharmashastra (Manu 8.41) one reads that a king who knows the sacred law (dharma) must inquire into the customary laws (caritra) of castes, districts, guilds and families and thus settle the peculiar law of each. Vide Menski, Werner Hindu Law Beyond Tradition and Modernity, Oxford University Press 2003, Chapter 3. Vide also Lingat (1967 : 197 sqq.).

139 Scholars of India have questioned this ; they contend that, although there may be a difference in the material content, the dharma is a kind of natural law or an ide- 
ethics and customary laws, but there was no universal or absolute law. And there was no legally constructed state which might have provided legal guarantees for economic activities, for the all-pervading dharma doctrine did not provide an incentive for legal rationalization. There were royal edicts, but the king did not make law but was supposed to enforce the respective dharma and customary laws of the various groups. If from time to time a capitalistic development seemed to blossom, this was due to the power of the guilds and other groups which organized the use of arbiters and private tribunals. Nevertheless, credit relationships normally existed only among sib-members, and joint liability of partners was lacking as any law of corporations was rather undeveloped (RI: 52).

Weber did not mention the complicated development of Indian law after the arrival of the East India Company, for instance the ruling of the governor Warren Hastings in 1772 that in all suits regarding inheritance, caste and religious usages the laws of the Koran with respect to Muslims and the laws of the dharmashastras with respect to the Hindus should be adhered to, assuming that Hindu law can be found in books despite the crucial rôle of custom. Even in the apparently westernized Constitution of India - which remains remote for most rural Indians - many of the legal postulates of the old customary system (particularly with regard to personal laws) could not be legislated away. This Constitution of 1950 even specifies (III, 13, 3 a) that law includes custom having in the territory of India the force of law, and it also contains an article on fundamental duties $(51 \mathrm{~A})$, relating to the promotion of harmony and compassion and reminding the reader of the edicts of the emperor Ashoka. In fact, even Gandhi's stance against Western individualism and human rights was based on such legal postulates.

\section{Buddhist Countries and Japan}

Although Weber mentioned the legislative influence of Buddhist ethics in Southeast Asia (e.g. the protection of slaves), he also stated that a holy «law» as an object of particular learning could not develop because of

al law (Dumont, 1966, p. 333) or at least a functional equivalent of natural law. Decisive is its critical distance from customary law, royal edicts and practiced jurisprudence (Dieter Conrad Zwischen den Traditionen Stuttgart : Fritz Steiner 1999, p. 360). 
Buddhist ritual formalism and its ethic of conviction. These all too short comments need to be expanded on the basis of more recent research related to Thailand or Siam.

The Code of the Great Seals of 1805 consisted of a body of general rules, derived from the Siamese dhammasattam, a sacred and immutable code, first assumed to have been compiled under the legendary king Mahasammata (the great elected), and of royal ordinances which were not sacred and could be repealed. Royal ordinances could become permanent laws and part of the Code not because they emanated from kings, but only to the extent to which they were considered as illustrations or derivations of the eternal sacred law; they drew their authority from their conformity with the dhammasattam and merely supplemented it. Generally, though, the orders or proclamations of a ruler were only valid during his reign but could be reaffimed by his successor. Thus, the king was thought to be an upholder of cosmic law, he could give orders but not make law. Therefore, Siamese law was not considered as arbitrarily created by human authority or as the product of a legislative process. The calculability of the functioning of the legal process and legal security, so important for the development of modern capitalism, were in no way guaranteed.

Moreover, there were also what might be called autonomous legal domains: wide areas of unwritten customs of inveterate character, relating to family, commercial relationships and to the Order of the Buddhist monks (sangha). On the whole, according to Lingat ${ }^{140}$, there was no place in Siam for what we call modern law before the kings Mongkut and Chulalongkorn in the nineteenth century introduced Western - influenced legal codes.

Weber also treated Japan in his section on Buddhism, and it is true that Buddhism had, together with Confucianism, a strong influence on Japanese legal principles and unofficial law already since the Constitution of 604, formulated under crown prince Shotoku, which mentioned the Buddha, the Dharma and the Sangha. Nevertheless, more recent authors ${ }^{141}$ have insisted on the antilegal mentality of the Japanese and that Japanese law has largely been customary law, and Masaji Chiba has called Japan a Shinto society, pointing to the buraku spirit and the «community constitution» of local communities as well as to the prevalence of conciliation and

140 ,Robert Lingat «Evolution of the Conception of Law in Burma and Siam», 38.1 The Journal of the Siam Society (1950), p. 26.

141 D. F. Henderson Conciliation and Japanese Law Seattle 1965 
mediation, for «the notion that a justice measured by universal standards can exist independent of the will of the disputants is alien to the Japanese» ${ }^{142}$. Since the Meiji reforms there exists an interrelation and interaction between received Western laws (Prussian and, since the end of World War II, American law) and indigenous law.

Islam

Islamic law, Weber wrote, is a law of jurists which is a necessary condition of formalization and rationalization, although it is not a sufficient condition. The Koran may not be a code of law, but it contains sacred legal postulates, whereas human law is considered to be of an inferior kind, acceptable only if it is in accordance with Allah's will. ${ }^{143}$ The independent interpretation of Koran and hadith (collection of the prophet's sayings) was not seen as permissible after the «closing of the gates of ijtihad» in the tenth century, as prophetic legal capacity was now only attributed to the founders of the four orthodox law schools, and the consensus (ijma) of jurists became the basis of validity of any law.

Whereas in the Christian tradition and in canonical law the concept of the Pope's infallibility ex cathedra and the Church Councils were able to initiate adaptations and systematizations of the law, this was not possible, even in unavoidable cases, in the Islamic and particularly in the Shia tradition, except for the price of unsystematic casuistry and trickery ${ }^{144}$, as Weber said. Systematic law making with formal concepts was impossible, because the holy law could not be disregarded, nor could it be adapted to new situations which arose in practice. The assumption of the absolute correctness of the holy law (sharia) rendered impossible the formal element of occidental law which attributes a potential of rationalization and

142 Quoted from M. Chiba, Asian Indigenous Law. London 1986, p. 335

143 Since Shafi ( $9^{\text {th }}$ century legal scholar) a common methodology of interpretation has largely been accepted by all legal schools and the sources of law are seen in a hierarchical order: Koran, hadith (example of the prophet), consensus (of the community and of legal scholars) and analogical reasoning. This hierarchical view made the complete separation of sacred and secular law impossible.

144 To evade the sharia ban on interest (riba), the creditor, instead of lending the capital with interest, would buy something from the debtor for the exact amount of the capital payable in cash, and then resell it to him for a price amounting to the capital plus the interest, payable at a future date. 
of legality to the correct procedure. In Islam, the law is aimed at substantive justice or principles which is opposed to Weber's concept of formal rational law.

With regard to commercial activities, the concepts of corporation and of juristic person ${ }^{145}$ ( the business corporation, but, in fact, the concept of corporation in the Occident also extends to cities. guilds, universities etc.) were lacking, concepts which were of major importance for the capitalistic development of the Occident, but lacking were also the conceptual preconditions which allow the construction of a secular state as an «Anstalt» which is separated from religious life. ${ }^{146}$ On the contrary, the arbitrariness and unpredictability of the patrimonial rulers had the effect of strengthening the influence of sacred law, for instance by the immobilization of property in the form of waqfs to religious institutions which provided revenues to the founder and were protected against seizure by secular authorities (ES: 1096) ${ }^{147}$. Although Weber did not mention it, the Islamic rulers have always had the right to make administrative regulations and to set up the so-called mazalim courts which applied the rulers' regulations and even custom as long as they remained under the ambit of the sharia.

Official scholars, the mufti, gave authoritative legal opinions to the judges (qadi), but, like oracles, these opinions were given without any statement of rational reasons and thus increased the irrationality of the sacred law (ES: 821). The qadis (judges), on the other hand, interpreted the Koranic and hadith provisions largely as matters of personal discretion. Weber's term qadi-justice which he applied also to other legal traditions has its origin here. ${ }^{148}$ In the Shiite tradition (particularly in Persia) the ju-

145 This point is based on J. Schacht An Introduction to Islamic Law. Oxford 1964, p.155, whose analysis largely follows in Weber's footsteps. Moreover, while Weber mentioned only in passing the prohibition of interest taking in Islam

(ES: 583), - and not only of usury, as the English translation suggests -, Schacht is more explicit and also describes the various devices used in evading this prohibition (ibidem p. 78).

146 The state in Weberian terms: By means of agreed upon or imposed statutes rationally ordered institution (Anstalt), if for the enforcement of this order an apparatus for legal coercion exists.

147 Madrasas (Islamic colleges) were founded as charitable trusts under the law of waqf ; the founder could appoint himself as head, and nothing inimical to the spirit of Islam was allowed to be taught there. In this way, of cause, the sciences did not gain any institutional autonomy.

148 The Islamic tradition has also inspired Weber to formulate another concept: sultanism (arbitrary exercise of patrimonial power). 
risdiction of individual judges does not even seem to have been clearly fixed, for the parties could choose from among a number of judges from competing schools. (ES: 823)

Thus it was the religiously determined organization of the Islamic patrimonial states and the weakness of all legal guarantees of the patrimonial justice system which impeded a capitalistic development.

Today, at least in some countries, the closed doors of ijtihad may be slightly ajar as the so-called neo-ijtihad movement demands more independent judgement to adapt to the modern world.

\section{Jewish Law}

The positive law of Israel was created through berith with Jahwe and it was not impossible that it might be changed again, for it was not an eternal order like the dharma in India. The Torah and the interpretative holy tradition were considered as a norm in all areas of life. Like in Islam, the norm applied to coreligionists only, but, unlike the situation in Islam, the carriers of this legal tradition were not a dominating class or group but rather a pariah people. Commerce with outsiders was partially governed by relaxed ethical norms although the Jews tried to adapt themselves to the legal norms obtaining in their social and political environment.

In the pre-Christian centuries there developed the scholarly treatment of legal questions and the legal technique of consulting jurists (interpreters of the Torah) in Jerusalem and Babylon under an exilarch whose jurisdiction was officially recognized by the Parthian and later by the Islamic rulers, for the Jews enjoyed judicial autonomy and communal leaders imposed internal discipline and prevented Jews from resorting to non-Jewish courts. Only after the extinction of the office of the exilarch in the tenth century Western Judaism freed itself from the Eastern influence and from what Weber called the speculative and dialectical treatment of the Torah (ES: 825).

To obey the law was now all that mattered whereas magic was cast aside. But, besides the elimination of magic Weber pointed to the degree of systematization as a criterion for rationalization. Logically coherent systematization (ES: 828), though, was prevented by the technical nature 
of Jewish legal interpretation (AJ: 414) ${ }^{149}$ based on common sense and concrete casuistry while there was no opportunity for genuinly constructive rational thought and the formation of rational concepts as practiced by the Roman jurists. No distinction was made between legal and ethical or religious norms.

Weber considered it improbable that some legal instruments or techniques of capitalistic commerce were invented by the Jews or that they found in Jewish sacred law an appropriate context for their development. Restrictions on interest taking according to Deuteronomium 23, 21 were, in case of commercial credits, circumvented by the formation of a contract between bank and credit-taker (isqa) which interpreted the interest as a kind of profit-sharing. Contracts entered into for a lawful purpose were recognized and enforced even if a transgression was committed in drawing them up (e.g. written on a Sabbath), for the freedom of stipulation was assumed. It was thought that the Torah did not establish civil norms as ius cogens but rather as dependent on the will of the parties to the transaction, a ius dispositivum. ${ }^{150}$

To obey God's laws was the duty of Israel and of every Jew. But, as Guttmann who interpreted Weber's work on ancient Judaism, pointed out ${ }^{151}$, the Jews in their pariah situation did not feel responsible for the existing economic and political order where they lived (tax farming, slavery, political capitalism) and adapted to it to the extent that their laws and rituals permitted it. In this they were different from the Puritans who wanted to subject the world to God's domination. Therefore, the rational development of Jewish law was limited although the observation of the law and not ritual was the highest legal and religious duty.

149 Vide : Deuteronomium 4, 2 as well as the Talmud : Shabbat 63 a («a verse cannot depart from its plain meaning») and Sanhedrin 86 a (the necessity to consider the total context).

150 Menachem Elon «Law, Jewish» in: Dictionary of the Middle Ages vol. 7, p. 489

151 Julius Guttmann «Max Webers Soziologie des antiken Judentums» in: W. Schluchter Max Webers Studie über das antike Judentum. Frankfurt a. M. 1981, p. 326 
The Law within Russian Orthodoxy

Before the Revolution of 1917 there existed in Russia customary law, the legal codes imposed by the respective rulers, ecclesistical law and in the past the law of the city republics. Customary law was followed by the largest part of the population, the peasantry; it regulated mainly questions of property and of peace and order in the family and the mir (peasant commune).

The main legal codes, starting with the Russkaia Pravda (eleventh century), then the the Sudebnik (1497), the Sobornoe Ulozhenie (1649) and the Polnoe Sobranie Zakonov in the nineteenth century were imposed from above by the patrimonial rulers and often contained at least some foreign (Byzantian, Western) ideas. The application of these codes in daily life may be characterized by three observations: 1 . Judicial procedures often involved «God's justice», i.e. the judicial duel (supervised by state officials) and ordeals (water and iron). While in the West the Lateran Council ( 1215) had eliminated the ordeal from court procedure, Russia retained it well into Muscovite times and thus retained a formally irrational procedure. 2. As has been mentioned by many scholars ${ }^{152}$, although the law codes, e.g. the Sudebnik, paid particular attention to bribery, they were unable to eradicate it; in fact, justice often was but another name for the generation of income for the officials involved. 3. The law codes were occasionally supplemented or partially modified by decrees ( $u \mathrm{kaz}$ ) of the rulers which might be incoherent and modified again by subsequent decrees, particularly since Peter the Great, as the tsars were not tied by their own decrees. All this, of course, did not contribute to the formation of a calculable rational legal system.

With regard to legal concepts directly affecting economic life, Weber pointed out that Russian law recognized liturgical collective liability and the corresponding collective rights of the compulsory organizations (of the village commune, mir, and of craftsmen, artel, and merchant guilds), but

152 Daniel Kaiser The Growth of Law in Medieval Russia. Princeton University Press 1980, p. 121 and Leroy-Beaulieu L'Empire des Tsars et les Russes Paris: Robert Laffont 1990, p. 659 
that it did not know of the rational concept of the corporation as it was developed in the Occident (ES: 726) ${ }^{153}$

The government also created merchant guilds with liturgical responsibilities. In all cases of liturgical responsibility the hard-working members shared duties with the lazy ones - and this did not stimulate hard work.

Property was generally tied to services so that allodial property was largely absent. Moreover, there was no tradition of contractual agreements as it had been implanted in the Occident by feudalism. More generally it may be said that the idea of (commercial) contract can only flourish where the culture is ready for it. This was not the case in Russia, as Procaccia has shown on the basis of a comparison of Russian and Western iconography: there was no individualism in Russia, Eastern Orthodoxy had only contempt for worldly riches while in the West wealth was worthy of aspiration, and there was no tradition of empirical enquiry based on experience in Russia. ${ }^{154}$ Interest taking, though, was permitted already since the Russkaia Pravda. ${ }^{155}$

The population of the city republics of Novgorod and Pskov, governed by their own veche (general assembly) before their privileges were eliminated by the tsar Ivan III, lived by customary law and the Russkaia Prav$d a$, but Hanseatic tradesmen in Novgorod had their own court with territorial immunity and their own law, the Skra. ${ }^{156}$ Disputes between the native Russian population and the foreigners were the moving force behind ever new regulations.

153 Thomas Owen The Corporation under Russian Law 1800-1917. Cambridge U. Press 1991 describes the restrictive policies in Russia with regard to the received law of corporations in order to saveguard the essence of the Russian autocracy.

154 Procaccia (2007) opposes Russia's «icon society» (the Orthodox icon as a window to the Russian spirit) to the Western contract society. There was, according to him, no individualism in Russia as the art of portraiture never materialized there ; and there was no empirical enquiry as there existed no illusion of perspective on a two-dimensional surface as in Western Renaissance painting, but rather a reverse perspective in Rublev's Holy Trinity in which the depicted event is shown as happening outside of the laws of human existence.

155 Weber pointed out that in periods of natural economy the Christian Church condoned the taking of interest and that the persecution of usurious lending arose only with the incipient development of actual capitalist instruments. What was involved, according to him, was the struggle in principle between ethical rationalization and the process of rationalization in the domain of economics (ES: 584).

156 Feldbrugge Law in Medieval Russia. Leiden: Martinus Nijhoff 2009 
Ecclesiastical (canon) law governed clerics and lay persons residing on church property as well as matrimonial law. This law was written law and it required written documentation. As such, it was able to influence some areas of secular law (inheritance, testimony) where documentary proof was required for evidentiary puposes. But it was not able to initiate a more general shift towards more rational modes of proof as in Occidental jurisprudence.

In Russia there was no scholarly interest in law before at least the seventeenth century, and then it was based on Byzantine law and particularly the Ecloga ${ }^{157}$ rather than on Roman law. A formally rational law was not developed because Orthodox canon law remained stifled under Russia's caesaro-papistic rule. According to Weber, the patrimonial codifications of the nineteenth century before the liberation of the serfs constituted largely the status law of the small privileged strata and left untouched the peasantry (ES: 858).

\section{Canon Law}

The Christian emperors of Constantinople, characterized by Weber as caesaro-papistic, convoked the general church councils and they confirmed the decisions of these councils which then became part of the canon law. In the novella 131 the emperor Justinian also decreed that the canons of the previous ecumenical councils should have the status of law and thus be incorporated into the legal order of the state. This meant that holy canons might be abolished by imperial decrees ${ }^{158}$ and that in any case state laws were applicable within the Church concerning all questions in regard to which no canon law had been passed. No clear independent canon law development could take place ${ }^{159}$, at least in regard to the exterior or adminis-

157 D. Kaiser The Growth of the Law in Medieval Russia. Princeton U. Press 1980, p. 173

158 W. Hartmann \& K. Pennington (ed.) The History of Byzantine and Eastern Canon Law to 1500. Washington: Catholic University of America Press 2012, p. 128

159 In the ninth century the Patriarch Photios in the Eisagoge tried to at least relatively separate the duties of the imperium and of the sacerdotium (considering the politeia as the body and the church as the form), but these finally remained, in the view of the Eastern Church, two principles (archai according to Leo Diaconus, a Byzantine historian) and not two powers (potestates) as was later claimed during 
trative aspects of church life (Constantine was, according to Eusebius, the overseer of exterior church matters ${ }^{160}$ ); no law schools, even of the Islamic sort, existed, and it is not surprising that many collections of church laws came to be called nomocanons, an expression of the fusion of imperial and church laws, as they contained both imperial and canon laws. Eastern canon law, according to Weber, remained unchanging and without influence on economic life.

But important changes took place after the Schism between the Eastern and the Western Church and in the course of the Investiture Struggle and the Papal Revolution. Gratian, in his Decretum (Concordia discordantium canonum, 1140 A.D.) which distinguished between divine law, (Stoic) natural law, ecclesiastical laws, secular laws, and customs, on this basis created a hierarchized and systematized body of ideas and laid the foundation of Western canon law which differed significantly from the canon law of the East. It implied the idea that customs must yield to natural law so that custom lost its sanctity. ${ }^{161}$ Moreover, a clear dualism between secular and canon law developed, avoiding all hybrid structures as they exist in other sacred law traditions. In the medieval universities the teaching of secular law and canon law was separated.

The jurists did not concern themselves with responsa as elsewhere, but with conciliar resolutions and Papal decretals (and even created such sources by deliberate forgery: the Donation of Constantine and the Pseudo-Isidorian Decretals). Canon lawyers created the term positive law (laid down by human law makers, distinct from divine law and natural law). Legislation was thus produced by rational enactment and inconvenient previous regulations (as in the case of usury) could even be set aside $\mathrm{ra}$ tione temporum habita (because of the circumstances of the time). A decisive factor was the unique organization of the Catholic Church as a rational compulsory institution (Anstalt) with rationally defined bureaucratic offices (ES: 828) ${ }^{162}$.

the Investiture Struggle in the West.. The Leo Diaconus text can be found in B. G. Niebuhr (ed.) $1828: 101$ sq.

160 It is true, though, that there has been some debate about the Greek expression

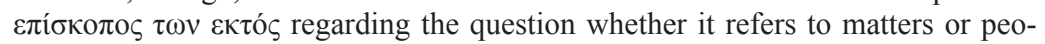
ple.

161 Berman (1983) p. 145

162 The Church included elements of the concept of Anstalt into the older concept of corporation. The concept of corporation in Roman law implied the separation of collective and individual property (ES: 715); the concept of Anstalt (often trans- 
But, as Weber mentioned (ES: 830), the theoretical claim to an all-embracing substantive regulation of the entire conduct of life which all systems of theocratic law share had few effects in the Occident because canon law had a serious secular competitor in Roman law since the «rediscovery» of Justinian's Digests.

Weber believed that the practical impact of canon law on commercial law was minimal, and there was indeed a strong opposition against all claims of the canon lawyers to settle secular affairs. With regard to legal contributions Weber wrote that the canonist concept of corporation opened the way to the concept of the state as a legal institution. But the canon law's main influence on secular law lay in the field of procedure and proof, in particular by an inquisition operating ex officio which tried to establish the true facts of a case. Procedure was now considered as part of natural law, and not of custom or positive law. In his Dictatus Papae (1075) the pope Gregory VII had declared that no one should dare to condemn one who appeals to his apostolic chair. But, as it was clear that an appeal from a decision of an ordeal (considered to be a judgement of God) was impossible, it followed logically that the old system of irrational proof by hot iron and water could not be used any longer and only proof based on evidence became acceptible. ${ }^{163}$ Since the Fourth Lateran Council (1215) written records of proceedings had to be kept in ecclesiastical courts and clerics were not allowed to participate in ordeals.

\section{European Secular Law}

Roman Law

When the Pandects (Digests) of the Roman emperor Justinian had been «rediscovered» in the eleventh century, the reception of Roman law created a profession of jurists who graduated from universities like Bologna and were employed throughout Europe. Already in Rome a secular literary stratum of legal advisors had developed a secular law (ius as opposed to

lated as institution), a legal concept developed much later, implies that it can act legally only though its organs, that its members have no influence on its management (ES: 707) and that it is bound by formal rational law.

163 K. Pennington «Due Process, Community and the Prince in the evolution of the ordo iudiciarius» in: Rivista Internazionale di Diritto Comune vol. 9 (1998), p. 12 
fas), and as there was no sacred law with any binding force and the mind was unencumbered by any theological or ethical concerns, as Weber wrote (ES: 854), the purely logical elements of legal thinking had increased.

The formal and logical qualities of Roman law brought it to supremacy in Europe ${ }^{164}$ with the help of the Bologna-trained jurists and legal glossators ${ }^{165}$ - except in England where there existed already a national system of legal training - while the substantive Roman law incited little interest. In fact, all specific legal concepts of modern capitalism (shares, bill of exchange, commercial company, land register, mortgage etc.) originated in the Middle Ages and not in Rome.

\section{Natural Law}

Natural law, according to Max Weber, is the sum total of all those norms which are valid independently of, and superior to, all positive law, and which provide the very legitimation for the binding force of any positive law (ES: 867). It is, Weber continued, the only consistent type of legitimacy of a legal order which remains once religious revelation and the sacredness of tradition have lost their force. The lex naturae (natural law) was a creation of Stoic philosophers. It was taken over by Christianity not in its original form (a golden age and a blissful state of equality of all human beings), but in its relative interpretation for the purpose of constructing a bridge between its own ethics and the norms of the world: political subordination, the diversity of status and even slavery had to be accepted, according to relative natural law theory, as facts of life after the Fall and as remedies for men's viciousness. As such, natural law was a cultural and not an ethical value. ${ }^{166}$

164 The prevalence of formal legal thinking even led to the theological idea that the relationship between God and man is a legally definable relationship and that salvation is settled by a legal process (Anselm) (ES: 553).

165 Weber's view has been complemented by Breuer's observation that Roman law left more scope to the individual than the laws of other advanced civilizations (in China the individual was «hors la loi»), and a connection between individuals needed to be found on a formal level (Stefan Breuer «Imperium und Rechtsordnung in China und Rom» in: S. Breuer \& H. Treiber (eds.) Zur Rechtssoziologie Max Webers. Opladen 1984, p.110)

166 Weber spoke of cultural ideals which the individual wants to realize, as opposed to ethical duties which he ought to fulfill (CMW : 104). 
Modern natural law theory stems from ideas indigenous to England that every member of the community has certain inherent natural rights (the rights of the barons in the Magna Carta, the rights of every human being in the seventeenth and eighteenth century). It led to the social contract theories of the seventeenth and eighteenth century, according to which society is the result of the decisions of autonomous individuals and as such artificially constructed. On the other hand, it was also influenced by certain Puritan sects. Jellinek, whom Weber mentioned approvingly, had shown this with regard to religious freedom in the Virginia Bill of Rights where he found the idea that inalienable innate rights of the individual have a religious and not a political origin. ${ }^{167}$ In any case, Weber insisted that only the Occident has known «natural law» and with it the complete elimination of personal laws and of the ancient maxim that special law prevails over general law (ES: 883).

Natural law can be either formal or substantive. In its formal version it had individualistic aspects and led to the principle of freedom of contract and the full development of the concept of property on the basis of contractual transactions. The substantive version was introduced by socialist theory and social welfare legislation which justified the acquisition of wealth by one's own labour only.

The «just price» of labour was one of the more important natural law elements of economic doctrine. Weber described how the labour value price corresponding to the subsistence principle was gradually replaced by the competitive price, considered as the «natural price» in the same measure as the market economy progressed. Among the Puritans and throughout the whole puritanically influenced Anglo-Saxon world this principle became dominant whereas the price which did not rest on competition in a free market (but was based on social welfare considerations) was considered «unnatural» (ES: 872/3).

Depending on the concept of nature and the concept of law, the most contrasting interpretations of natural law have been advanced. Nevertheless, Weber believed that many axioms of natural law have been discredited and lost their capacity to provide the metaphysical basis of legal systems as legal positivism advances irresistibly. Its continued significance lies in the fact that natural law dogmas have strengthened the tendency to-

167 Georg Jellinek Die Erklärung der Menschen- und Bürgerrechte. München: Duncker \& Humblot 1895 p. 57 
wards logically abstract law or the power of logic in legal thinking (ES: 873/4).

\section{Continental European Law}

By the end of the Middle Ages the courts in continental Europe had adopted the canonical judicial procedure based on Roman law (ordo iudiciarius). Moreover, Roman legal concepts were cleansed of all national associations and made more abstract; purely systematic categories such as «legal transaction» were created. Law was not taught by observing the actions of legal practitioners (judges) or by studying particular cases (as it was done in the English inns of court), but by professional teachers who expounded on rules of law contained in authoritative texts. These teachers considered it as their task to construe legal situations in a logically impeccable way and to see in law a logically consistent and gapless complex of norms (ES: 855). Thus, the logical systematization and Eigengesetzlichkeit ${ }^{168}$ of the law was the consequence of the intrinsic intellectual needs of the legal theorists and not always in step with the practical conditions of life and commercial interests. The law was now thought to be continually transformable and devoid of all sacredness of content. The school of the Pandectists in the nineteenth century around Carl von Savigny was characteristic of this tendency in continental European jurisprudence.

The practical need for a calculable law, Weber wrote, did not play any considerable rôle, for this need may be gratified as well by a formal empirical case law as in England where the judges are bound by precedents and thus by calculable schemata (PW: 148); nevertheless, the rationalization and systematization of the law and the increasing calculability of the legal process constituted one of the most important conditions for the existence of economic enterprise which cannot do without legal security (ES: 883).

But, on the other hand, there have been anti-formalistic tendencies and a movement against the methodology of the Pandectists. The enlightened despotism and patrimonialism of the eighteenth century led to more substantive justice (e.g. Prussia's Allgemeines Landrecht), even though the

168 ES: 885 translates: «intrinsic necessities of logically consistent formal legal thinking». 
formal qualities of the Roman law tradition can account for the fact that the patrimonial justice elements of continental Europe did not lead to the path of patrimonial administration as elsewhere so that the law retained its juristically formal character (ES: 853). Later, postulates of human dignity, good morals and bona fides as well as the idea of the welfare state led to more substantive justice, challenging juristic formalism so that - in nineteenth century Germany - systematization and codification could only be achieved in special fields with special interests, e.g. commercial law and the law of negotiable instruments (ES: 858). Nevertheless, the cultural significance of formal rational law was for Weber beyond any doubt.

Some legal concepts which were developed in the Middle Ages became unique to the Occident. In Florence and other medieval business-oriented cities the old identity of household and workshop/office and their solidary responsibility fell apart; fraternal relationships were replaced by business relationships and contracts, and business partners were not necessarily household members any more. Moreover, business activites were performed in a separate enterprise. This may at the beginning have happened in ad-hoc groupings for long-distance trade like the commenda ${ }^{169}$, but soon it became more permanent. Crucial was the separation of household and business not only on a spacial level but also for accounting and legal purposes, and the development of a corresponding body of laws such as commercial register, separate property of the firm, appropriate bankruptsy laws. ${ }^{170} \mathrm{In}$ its most rational form this meant the complete separation of the legal sphere of the household members from the separately constituted legal sphere of the business entity, its legal personality (ES: 707), and led to the development of the concepts of limited liability and to joint stock corporations in Germany and the corresponding legal constructions elsewhere.

The codification of a rational law system and its administration by trained officials was related to and dependent on the development of the modern institutional state (Anstaltsstaat) (ES: 653). Until modern times it

169 In the Middle Ages, the commenda was an undertaking in which a person made commercial use of the goods of another person, and at that other person's risk, in exchange for a share of the profit (HCP : 65).

170 ES: 379; In this context, Weber pointed to the fact that in China the joint liability of the family stood behind the debts of the individual, and that laws on a separate property of the firm seem to be absent. Credit was until recently dependent on the kinship group (ES: 380). 
has been known only in the Occident and it can be characterized by what has been called a double monopolization: 1 . The monopolization of law and law-making by the state and the elimination of all non-state and nonpositive law and 2. the monopolization of the legitimate use of physical force in the enforcement of the legal order.

The first monopolization had as a consequence that all local bodies of law as well as the laws of personally limited application which are seen as different from the body of rational law claiming universal validity were put on the defensive. Where reason wants to reign, Weber wrote, all law which has for its existence no other justification than the fact that it exists, especially customary law, must disappear or will at least be regarded as inferior. ${ }^{171}$ Perhaps not surprisingly, Weber wrote of the half-mystical concept of customary law and did not consider it very useful (ES: 319). All modern codifications have been at war with customary law (ES: 856). Elsewhere Weber wrote that modern economic life has destroyed all status-determined associations which used to be the carriers of law, and has led to the monopolization of one universalist coercive institution (ES: 337).

In Germany, the modern institutional state was called a Rechtsstaat (a state ruled by law) where the political authority made the laws and was bound by them. The basic form and source of law was now legislation rather than custom or precedent or equity; the positivist tendencies in nineteenth century continental Europe (Weber's Europe) did not presuppose a fundamental law which is derived from a source outside or above the state so that law in the large sense (Recht, droit, ius, pravo) was identified with law in a narrower sense (Gesetz, loi, lex, zakon). ${ }^{172}$

The fundamental characteristics of bureaucratic administration under formally legal domination were a. continuous rule-bound conduct of official business, $b$. the establishment of spheres of competence, $c$. the principle of hierarchy, d. specialized training, e. the separation of ownership

171 Since Weber's time this tendency seems to have spread even to international law. Weber had considered international law as an expression of a common culture (RI : 145), but in a quarrel between Thailand and Cambodia, both of common Buddhist traditions and customs, the International Court of Justice neglected to take account of them. Vide Buss 2010.

172 Harold Berman «The Rule of Law and the Law-Based State» in: W.E. Butler (ed) Russian Legal Theory 1996, p. 451 
from the means of production, f. no appropriation of positions and g. written records (ES: 217).

The situation in the common law countries to which we shall now turn was slightly different because the rule of law there implied that the basic principles of justice (Magna Carta, Bill of Rights, due process, civil liberties in America) may not be infringed by the law making authorities. It was also different, to a degree, because the continental Anstaltsstaat became rather a quasi-Anstalt in England as the state had no legal personality (only the Crown had it), and this permitted a stronger position for the individual than on the Continent. ${ }^{173}$

\section{English Common Law}

The kind of legal trainig which English lawyers and judges received in the Inns of Couts produced, according ot Weber, a formalistic treatment of the law, preoccupied with precedents and analogies (ES: 787). English law finding is not, traditionally, like that on the European continent, the application of legal propositions logically derived from statutory texts. No systematic and comprehensive treatment of the law has taken place; rather, as Weber said, a practically useful scheme of contracts and actions was aimed at. Weber considered the common law as formal, but also as an essentially empirical art based on external criteria where one can still observe the charismatic character of law finding (ES: 890), and he explained that no general concepts were formed by abstraction or by logical interpretation of meaning. In a purely empirical way, he wrote, the practitioner of common law always moves from the particular to the particular.

Weber distinguished two kinds of formal law. The relevant charcteristics of a legal question may be of a tangible nature, i.e., perceptible as sense data, or they may be formulated through the logical analysis of meaning and legal concepts in the form of highly abstract rules (ES: 657). This makes the difference between the English common law and European continental law.

In passing, Weber also mentioned the quite patriarchal and highly irrational jurisdiction of the justices of the peace, a kind of qadi-justice quite

173 Siegfried Hermes has described Weber's view of the Anstaltsstaat in England in much more detail ( S. Hermes ««Staatsbildung durch Rechtsbildung» in : Anter/ Breuer Max Webers Staatssoziologie Nomos : Baden-Baden 2007). 
unknown on the Continent (ES: 891), and the legal dualism, produced by the co-existence of common law and Equity in the Court of Chancery. ${ }^{174}$

Equity as well as the concept of reasonableness moved the English law tradition closer to the side of substantive law.

\section{A Retrospective View of European Secular Law}

As has been seen, Weber considered modern European secular law as formally rational. This formal rationality has two versions: Continental law which systematizes and English common law which works on a empirical basis. Formal rational law is enforced by the state as Anstaltsstaat (again in two slightly different versions), a universalist coercive institution which represses all other kinds of law, in particular customary law. Formal rational justice was for Weber (who in this matter quoted approvingly another legal scholar, R. v. Jhering - ASS: 480) the enemy of arbitrariness and the twin sister of liberty, it was a framework to regulate formally free people.

This modern secular law, influenced by natural law ideas, has an affinity to individualism in contractual relations. Before the rise of the modern capitalistic society there existed mainly the status contract which created personal relationships and produced a complete legal modification of status or social position of the persons involved (e.g. in the feudal contract). But to the extent that parental groupings declined and the economic system became more market oriented, the purposive contract (which in the past mainly described the relationships between clans or nations) has become acceptable in vast areas of social life. It contributes to the dissolution of traditional relationships for the purpose of economic exchange and assumes the existence of formally rational law.

While in the English Middle Ages legally binding private contracting had been possible only in circumscribed circumstances which were recognized by a writ (a form of action), modern purposive contracts trace their life in England to Slade's Case (1602) and on the European continent

174 Weber considered Equity as substantive rational justice, similar to Solomonian judgements or judgements by Sancho Panza when he happened to be governor (ES: 845). In sixteenth century England it was argued, based on Aristotle, that the nature of the equitable is a correction of law where it is defective owing to its universality. Vide J. H. Baker An Introduction to English Legal History. London 1971, p.42. 
around the same time to Leonardus Lessius who stated that a promise has a binding force. Only since then the parties were free to formulate their agreements as they wished and they did not any more depend for their validity on a simultaneous exchange. Quite in line with the Zeitgeist, Adam Smith in his The Wealth of Nations (1776) wrote that self-interest generates social welfare, and the state and the courts were willing to protect private agreements (contracts) so that the whole market economy was now based on commercial contracts entered into by individual interests.

The rationalisation of occidental law has been a formal rationalisation which does not guarantee a correspondent substantive rationalisation. Frequent eruptions of substantive considerations and demands, however, produce an increasing tension between legality and legitimacy or between efficacy, calculability and impersonality on the one hand, and personal relations, fraternity and equality on the other. Max Weber did not look at the rationalisation of law and rationalisation in general in an optimistic way but rather saw it as an expression of the organization of despair.

\section{Coda on Modern Comparative Law}

While in the last hundred and fifty years occidental law, sometimes in its more formal version and at other times with more substantive elements, has been adopted in most Asian countries, it has by no means simply replaced the traditional Asian laws. Western legal positivism is often considered to have a reductionist perspective which excludes the deeper structures of the law (legal culture, language, religion, custom). Quite often, therefore, traditional Asian law functions to undermine provisions of the newly introduced Constitutions that attempt to separate the State from religion and tradition; it supplements, modifies and undermines State law, thus becoming what has been called unofficial law. This is why Masaji Chiba (1986) distinguishes even in modern Asian countries between 1. official law (which may contain religious law, e.g. Islamic or Hindu law, and also the traditional laws of family and guilds insofar as officially sanctioned), 2. unofficial law which is not officially sanctioned but accepted in practice by general consensus and often studied as customary law, and 3. traditional legal postulates (sacred truths, national philosophies) which found or justify official or unofficial law.

All this has produced new orientations in historical comparisons since the advent of globalization. Not single societies or cultures, but their rela- 
tionships, borrowings, or adaptations to each other, or the clashes between them, have often become the subject matter of the comparative sociology of law for far from creating uniformity worldwide, the reception of Western laws has led to a complex pluralization and hybridization of legal systems all over the world. ${ }^{175}$ The idea of multiple modernities ${ }^{176}$ which asserts that modernity and Westernization are not identical and which distinguishes between ideological and institutional premises has become a powerful tool of understanding. Weber perhaps anticipated these ideas by his distinction between spirit and form and by his suggestion that societies which have been unable to create capitalism or its spirit may well be able to adopt its (legal and administrative) system from the outside. This is perhaps what Schluchter ${ }^{177}$ has called Weber's second thesis. While the first thesis relates to the development of modern occidental rationalism out of its own historical sources, the second thesis is concerned with the possibilities and difficulties of its spreading throughout the world. ${ }^{178}$

175 Werner Menski Comparative Law in a Global Context London 2000, chapter 1. An example can be found in the work of R. Sakrani (2009) who describes the hybrid legal structure in Tunesia where the formal character of occidental law collides with the lack of formality of Muslim law and where there are even differences with regard to the concept of contract (2009:201). Only good faith and the belief in the essential identity of the human spirit may be able to hold this together (2009: 204).

176 Of particular importance in this context is the work of S.N. Eisenstadt, e.g. his article published in 2000 .

177 Schluchter $2006: 316$.

178 Weber wrote that the Chinese may more easily adopt modern capitalism than the Japanese (RC:248) and the Japanese more easily than the Hindus (RI:325). 


\section{CONCLUSION}

\section{The «Author's Introduction» as a Conclusion}

\section{Basic Literature:}

«Author's Introduction» in: Max Weber The Protestant Ethic and the Spirit of Capitalism transl. by T. Parsons 1930, introduced by A. Giddens. London: Routledge 2004, pp. XXIX-XLI

«Vorbemerkung» in: Max Weber Gesammelte Aufsätze zur Religionssoziologie vol. 1 Tübingen: Mohr (Siebeck) 1920 pp.1-16

Weber's «Preceding Remark» prefaces the whole collection of the Collected Essays in the Sociology of Religion. It is one of Weber's last texts, and it does appear like a conclusion to these Collected Essays. The English translation, also entitled «Author's Introduction», has often been included, albeit misleadingly, with the English text of the Protestant Ethic and the Spirit of Capitalism. Weber here states that he intends to explain problems of universal history and to ask himself to what combination of circumstances the fact should be attributed that in Western civilization cultural phenomena have appeared which, «as we would like to think», are of universal significance. He makes it clear that he, as the son of modern European civilization, necessarily and justifiably chooses a culture-related perspective which admittedly is only of a heuristic value ${ }^{179}$, although he may not have doubted that European culture was of universal significance because of the effects which it continued and continues to have on other cultures. But universal significance does not imply universal validity

179 Certain modern authors have attributed to Weber an orientalist or «westocentric» ideology in Edward Said's sense. Sara Farris, for instance, accuses Weber of an unsympathetic and unflattering depiction of Asiatic «non-personalities» who lack the characteristics of the Western type of personality (Farris 2013: 207). Clearly, these authors are not aware of the fundamental distinction between normative eurocentrism which Weber avoided, and heuristic eurocentrism which he considered justified and even necessary from a methodological point of view. There should be no question that the conditions under which a science develops are one thing, and that the objective status of its discoveries or statements is another. 
Only in the Occident, he wrote, there exists a science which we today recognize as valid; elsewhere one does not always find rational proof, the rational experiment and the rational concept.

Only in the Occident there is rational harmonic music and, in fact, the rationalization of art by the utilization of the spatial perspective, and the utilization of the Gothic vault in architecture.

Only in the Occident there is trained and specialized personnel in a sense and to a degree which approaches its present dominant place in our culture, the trained official, the pillar of both the modern State and of the economic life - the cage in which we have to live. Only here we find the State itself with a rational written constitution and an administration bound to rational rules of law, administered by trained officials.

And the same is true of the most fateful force in our modern life, capitalism. How should modern capitalism be characterized?

The impulse to acquisition, the pursuit of the greatest possible amount of money and any acquisition by force has nothing to do with capitalism, for the auri sacra fames (the greed for gold) is as old as the history of mankind. Capitalistic economic action is rather based on the expectation of profit by the utilization of formally peaceful means. It is found where the acquisition is rationally pursued, and where a calculation of capital in terms of money is made with an initial and final balance. But even in this sense there has been capitalism in all civilizations, in China, India, Babylon, Egypt and elsewhere in the shape of money lenders, colonial entrepreneurs and as tax-farming and adventurer capitalism. But in modern times the Occident has developed a capitalism in form and direction which has never existed elsewhere: the rational capitalistic organization of formally free labour. It is connected to the idea of the citizen. The concept of the citizen and of the bourgeois did not exist elsewhere although there have been all sorts of legal differences between town and country in other cultural areas.

One can certainly name other important developmental elements of modern capitalism: the separation of the business from the household, rational bookkeeping, the legal separation of corporate from personal property, but all these peculiarities of modern capitalism derive their significance from their association with the capitalistic organization of labour (formally free labour) or rather: the bourgeois capitalism with its rational organization of free labour, for exact calculation is possible only on the basis of free labour. 
The peculiar modern Western form of capitalism has been strongly influenced by the development of technical possibilities and that means: by the peculiarities of modern science. On the other hand, the development (not: the origin) of these sciences received important stimulation from economic incentives and these, in turn, are derived from the peculiarities of the social order of the Occident: the rational structure of law and administration. For modern rational capitalism has need not only of the technical means of production, but of a calculable legal system and of an administration working on the basis of formal rules. And where did that law in its formalistic perfection come from? Capitalistic interests have no doubt helped to prepare the way for the predominance in law and administration of a class of jurists trained in rational law, but these interests did not create that law. And why did not capitalistic interests produce a similar outcome in China or India? Why did not the scientific, the political or the economic development there enter upon the path of rationalization which is peculiar to the Occident?

In all the above-mentioned cases it is a question of the specific rationalism of Western culture. Now, by the term «rationalization» very different things may be understood. Not only the most diverse spheres of life can be rationalized - mystical contemplation as well as war or economic activity and each of these spheres may be rationalized in terms of very different ultimate values. And what is rational from one point of view may well be irrational from another. To characterize the differences of the various civilizations it is then necessary to search what spheres of social life are rationalized and in what direction. Weber's concern was therefore to work out and to explain the special peculiarity of Occidental rationalism, and particularly of its modern form.

Obviously, every such attempt at explanation must take account of the economic conditions. But the opposite causal relationship must not be left out of consideration. The explanation of economic rationalism must not only take account of rational techniques and rational law, but also of the ability and disposition of humans to adopt certain types of practical rational conduct. Magical and religious forces and the ethical ideas of duty based upon them have always been among the most important formative influences of conduct. Weber is concerned with these forces.

In the Protestant Ethic Weber had attempted to consider only one side of the causal relationships, namely the influence of certain religious ideas on the development of an economic ethos. The later studies on «The Economic Ethics of World Religions» attempted to investigate both causal re- 
lationships as far as it seemed necessary to find points of comparison with Western development. For it is Western development which in the last analysis is intended to be analysed further, and only in the described way does it seem possible to attempt a causal attribution of those elements of the Occidental economic ethic which differentiate it from others. Weber's studies of the world religions, presented and analysed here in chapter III, do not claim to be complete analyses of civilizations. On the contrary, in every case they emphasize those elements in which it differs from Western civilizational development, for, in the final analysis, Weber was concerned with the understanding of Western culture.

Specialists like sinologists, indologists or semitists will have to make a final judgement about the factual correctness of the analyses. Weber was well aware of his limitations, being obliged to work with available translations. He undertook the studies only because expert studies with his special purpose and from his particular point of view were not available. ${ }^{180}$ Finally, Weber also admitted that the results of ethnographic research have hardly been used by him, but he believed that this might be excusable because he was mainly concerned with the religious ethics of the social strata which were the culture carriers of their respective regions.

\section{Commentary}

It was Weber's ultimate intention to describe and to explain the distinctive character of the whole of Occidental culture, the particular kind of rationality which pervaded all areas of life: the rational-methodical conduct of life, the rational capitalist enterprise, the rational state, the formally rational law, rational science, and the rational music based on harmonic chords. In order to achieve this goal he had compared the Occidental culture with the major other cultures and had tried to show why the abovementioned phenomena had not occurred in those cultures.

180 One is reminded here of Weber's remark in his «The 〈Objectivity» of Knowledge in Social Science and Social Policy» that by relating known facts to known viewpoints one can nevertheless create something new (CMW: 138). 


\section{Science}

With regard to science Weber pointed out that only the Occident's degree of scientific development is today considered as valid, although his writing on science is rather limited. In «Science as a Vocation» (FMW: $129-$ 156) he traced a short history of science, starting with the rational proof and the rational concept in ancient Greece, ${ }^{181}$ followed by the rational experiment in art (Leonardo and the experimenters in music who wanted to raise art to the level of science) during the Renaissance period, without which further scientific development would have been impossible. Since the School of Chartres (twelfth century) ${ }^{182}$ and since Abélard it was thought that through rational knowledge of the structure of the created world and thus by reason alone the individual scholar could achieve or contribute to the knowledge of the creator. There was no suggestion that individual reason was to submit to the consensus of scholars, as in Islam, or to the fellowship of the sobornost' (consensus ecclesiae) which alone can make true understanding possible in Eastern Christianity.

Weber's summary history of science can perhaps be complemented by Berman's contention ${ }^{183}$ that legal science as it developed in the eleventh and twelfth century under the impact of the Papal Revolution may be regarded as a progenitor of modern Western science, and this on the level of the value premises (objectivity, skepticism), on the organizational level (the newly emerging institution of the university as a corporation with legal personality and with free research and teaching), and on the methodological level (the law was systematized as an integrated body of knowledge so that the validity of particular legal rules could be demonstrated by their consistency with the system as a whole). To this should be added the emperor Frederick Barbarossa's authentica habita (1158), a legislative act which was issued for the protection of students studying Roman law in Bologna (as opposed to clerical students studying canon law), and which

181 Elsewhere Weber also mentioned the mathematical thought which is the Greeks' everlasting contribution to modern science and which was lacking, according to him, in China and India. (RI: 161)

182 R. Klibansky «The School of Chartres» in M. Clagett et al. (ed.) Twelfth Century Europe and the Formation of Modern Society U. of Wisconsin Press 1966

183 H. Berman (1983) p. 151 
strengthened the autonomy of the university as a corporation. ${ }^{184}$ It rescued the independent study of Roman law from the threat of absorption by its rival, canon law. ${ }^{185}$

According to Berman, neither the classical period of modern science (Galileo, Kepler, Newton) nor the later advances would have been possible without the methods developed by the early jurists and without independent universities which could enact their own statutes.

With the Puritan spirit of the «man of a vocation» (Berufsmenschentum) specialization entered the milieu of science, and the application of science to practical goals, and with specialized personnel, is mainly a Protestant achievement (AC: 129). The needs of industry (Weber mentioned particularly the mining industry in RC: 151) assisted the intellectual forces in transferring the experiment to the natural sciences, and the relationship of science to the economy did contribute to the process of modern capitalistic development but also to the growing impersonality of the economic sphere. And although Western science was in Weber's opinion unique, his attitude with regard to it was ambivalent. He pointed to the disenchantment of the world by science ${ }^{186}$ and its rejection of the religious idea that the world may have a meaning (FMW: 154). But in Weber's opinion science cannot replace religion. Quoting from Nietzsche's Zarathustra, he sarcastically criticized the «last men who invented happiness» and he turned to Tolstoi in whose opinion science is meaningless because it gives no answer to the question: "what shall we do and how shall we live?» (FMW: 143).

\section{Architecture, Art, and Music}

In architecture, art, and music Weber was interested in the determination of the technical instruments employed for a given definite purpose although, of cause, the history of art does not recognize a «progress» with

184 Such autonomy of the university was of cause non-existent elsewhere, for instance in the Islamic colleges (madrasas).

185 Walter Ullmann Scholarship and Politics in the Middle Ages London: Variorum Reprints 1978, p. 136

186 The disenchantment of the world had already begun with the old Jewish prophets who had repudiated all magical means of salvation (PE: 61), but the Puritans and then science then completed this process. 
respect to the aesthetic evaluation of works of art. The development of the Gothic style was the result of the technically successful solution of an architectural problem in connection with the building of vaults over spaces of a particular kind (CMW: 322). The discovery of perspective in painting was made during the Renaissance (although perspective of a different kind existed in traditional China) as a path to true nature (FMW: 142).

In his sociology of music (RSM) or, as he called it himself, in his history of music Weber asked why music oriented to harmony was developed only in Europe. He mentioned briefly the technical-rational preconditions for European musical culture: the modern system of notation (since Guido of Arezzo in the eleventh century), the setting down of the notes' relative time values, and a fixed scheme of bars so that the progression of the individual parts of a polyphonic piece in relation to each other becomes clear and unambiguous - which alone makes polyphonic compositions possible. All this, as Weber wrote to his sister Lili in August 1912, (MWG II/7 vol. 2: 638), was the work of monks.

But this was not enough. Weber's central concern was to characterize the peculiarity of the modern European tonal system in comparison with the tonal systems of other cultures and times (e.g. Indian ragas or the pentatonic system in China or ancient Greece). He found this peculiarity in chordal harmony and in the equal tempering of the pitch of the intervals between the twelve tones of the European scale. The Pythagorean «comma», a small, scarcely audible interval, symbol of the unrationalized pure tones of nature, was «eliminated» through a rational solution, the equally tempered pitch of the intervals (FMW: 281) since A. Werckmeister around the year seventeen hundred, so that greater rationality of the whole tonal system was now achieved and, for instance, the transposition of a melody from one key to another became possible. J.S. Bach explored the potentials of this newly established tuning method in his «The Well-Tempered Clavier». Our until recently exclusive education toward modern harmonic music is quite essentially supported by the piano.

But of course, Weber was well aware that the aesthetic sphere, including music, is a «life force» whose being is emotional and arational and often a means of ecstasy, in inner tension with all attempts of rationalisation. ${ }^{187}$ Music, wrote Weber, offers the power of this-worldly salvation

187 Christoph Braun «The Science of Reality of Music History: on the Historical Background of Max Weber's Study of Music» in: Sam Whimster (ed.), Max Weber and the Culture of Anarchy London: MacMillan 1999, 177-195 
from the routines of everyday life and from theoretical and practical rationalism (FMW: 342). There is indeed an inner tension, an irreconcilable conflict between Weber's music study which traces the rational solutions in Western music and his «Intermediate Reflection» where he writes about music in a very different way. Weber was not only a theoretician of rationality. ${ }^{188}$

\section{Formally Rational Law and the Puritan Conduct of Life}

Not the explanation of modern science as such nor the rationalization of music was Weber's primary concern, but rather what he considered the most fateful force in our life, modern capitalism, today's economic order with its rational organization of free labour. on the basis of rational science and technology, invested capital and machine production, and rational calculable law. What was his answer?

Harold Berman has praised Weber for confirming that the Investiture Struggle of the late eleventh and early twelfth century laid the foundations for the separation of church and state, that the new canon law was the first modern legal system, that the reciprocity of rights and duties of lord and vassal distinguished Western feudalism from that of eastern societies, and that the western city of the twelfth century was unique in conferring constitutional rights upon its citizens. Yet, Berman wrote, Weber was prevented from drawing the right conclusions from these facts by his historiography which postulates a sharp break in the sixteenth century between the Middle Ages and modern times. ${ }^{189}$ Berman did not spell out precisely what the right conclusions might be, but he clearly did not envision the possibility that there might be several great transformations in the history of a culture and even in different spheres of that culture, and that, moreover, there might be a meaningful adequacy between the results of these transformations. In fact, Weber saw two major transformations in the Occident as mutually reinforcing preconditions of the development of mod-

188 The philosopher Karl Jaspers who had been strongly influenced by Weber even during Weber's life time, seems to have come to the conclusion (after new revelations about Weber's personal life) that Weber's personal rationality revealed a complete openness to experience and its struggles, and not an essential oneness. Vide: Henrich's article in Mommsen \& Osterhammel (eds.) 1987, p.542

189 Berman 1983, p. 550 
ern capitalism. In the eleventh and twelfth centuries the Papal Revolution created the exterior preconditions, and between the sixteenth and eighteenth centuries the «Puritan Revolution» created the inner preconditions. Between the thesis of a mainly institutional transformation in the Middle Ages and the thesis of a transformation of the mentality after the Reformation Weber saw no contradiction. Each of these conditions developed independently and at different moments in history, but Weber saw an elective affinity (Wahlverwandtschaft) between them, creating a situation in which both favoured each other and a development of high inner homogenousness could set in.

In Asian religions there was customary law, qadi justice, formally irrational and substantively irrational law, even substantively rational law, but not formally rational and calculable law without which there may be adventurer or speculative trading capitalism, but no rational enterprise with fixed capital. And Asian religions offered magical, ritualistic and contemplative methods of salvation, there was the Indian bhakti and the institutional grace of Catholicism, but nowhere, with the possible exception of some sects (the Jainas in India and the Skoptsy in Russia) the methodical innerworldly ascetic work ethic can be found. (A schematic table can be found in the appendix).

Why did only the Occident develop a specifically «rational» culture with a particular formal orientation which in Weber's opinion has been of universal-historical significance? At the root of this development was the inner adequacy and even the mutual intensification of the kind and orientation of two rationalizations: the formal rationality of the exterior circumstances of life (the politico-legal circumstances) and the innerworldly practical rationality of the inner motivations of the Protestants. Having developed independently of each other, they created together the structure and the spirit of modern Western capitalism, supported, moreover, by rational science and technology. But this is not all, for the Protestant ethic in its secularized form was congenial and well suited not only for the modern capitalistic enterprise, but also for the officials of the bureaucratic state, based in turn on formally rational law, and for modern institutionalized and specialized science and technology. The specialized man of a vocation (Berufsmensch) has a cultural significance well beyond the economic sphere.

This double rationalization (the practical rationality of the Protestant ethic and the formal rationality of occidental law), supported by the goaloriented rational technology, is the fate of our age, and it implies bureau- 
cratization and specialization on the exterior level, and disenchantment and dehumanization/unbrotherliness on the interior level even as routinization has set, the religious roots have to a large extent died out and a secularized ethos, the spirit of capitalism, of the Beruf, is now left in the «iron cage» in which we are condemned to live. More than other times and circumstances, perhaps, Weber's statement that what is rational, or logically consistent, has some degree of power over humans (FMW: 324), characterizes the modern occidental situation. Weber showed no blind enthusiasm for this outcome, and he disdainfully wrote about today's «specialists without spirit, sensualists without heart» (PE: 124). His fundamental question remained: how can we live within modern «rational» culture and under modern capitalism which gives priority to the law of the market over ethical values? He wrote that «if one wishes to evaluate any ordering of societal relationships, one must in the last resort ... examine it with respect to the type of human being that it gives the best chances of becoming dominant, by way of external selection or inner selection of motives» (CMW: 321) $)^{190}$. Not the well-being of the people of future generations, but what kind of people they will be, what type of personality is encouraged by social development, was the question which moved Weber's thinking. He hoped that those characteristics which we think of as constituting the human greatness and nobility of our nature may survive in the future (PW: 15). The stagnation and ossification which characterized the decline of the Roman Empire and the imposition of a strict pax Romana were for him a discouraging example.

\section{The Contemporary Relevance of Weber's Comparative Sociology}

Weber's comparative studies can even today be more than a quarry of interesting concepts or a series of fragmented studies; they are also more than an array of hidden interlocking strategies and procedures which provide causal explanations of unique cases and developments, as Kalberg suggests. ${ }^{191}$ Their subjects are the major religious cultures of the world seen from the viewpoint of universal history, in which various complexes

190 Quoted from «The Meaning of 〈Value Freedom» in the Sociological and Economic Sciences» in CMW.

191 Kalberg 1994: 193 
of ideas and processes of rationalisation performed the role of switchmen which guided the respective interests.

Certainly, as Weber wrote in his essay on «Science as a Vocation» (CMW: 349 / 350), the (cultural) sciences can provide knowledge of techniques for controlling life (the concepts found in Weber's collected writings, used as a quarry), they can also provide methods of reasoning (strategies, procedures, as for instance Kalberg suggests), but, last not least, they can provide clarity and compel the individual to give an account to himself of the ultimate meaning of his conduct within his own cultural Weltanschauung as compared to all others, they make us realize that the inner consequences of our cultural choices in terms of meaning lead us, figuratively speaking, to serve this god and to offend that other god. Weber claimed that this is of value in our personal life. The historical and comparative sciences of culture are based on the assumption that it is interesting and responsible to participate in this awareness of ourselves as cultured beings or Kulturmenschen (CMW: 345), and that this is possible not by recourse to general laws, but only by reference to historical constellations, seen in the context of universal history. The Western Kulturmensch might then realize that different rationalities are deployed within the distinct spheres and orders of modern society (science, economy, law, bureaucracy etc.), but that rationality in the meaning structures of our life has diminished. 


\section{APPENDIX}

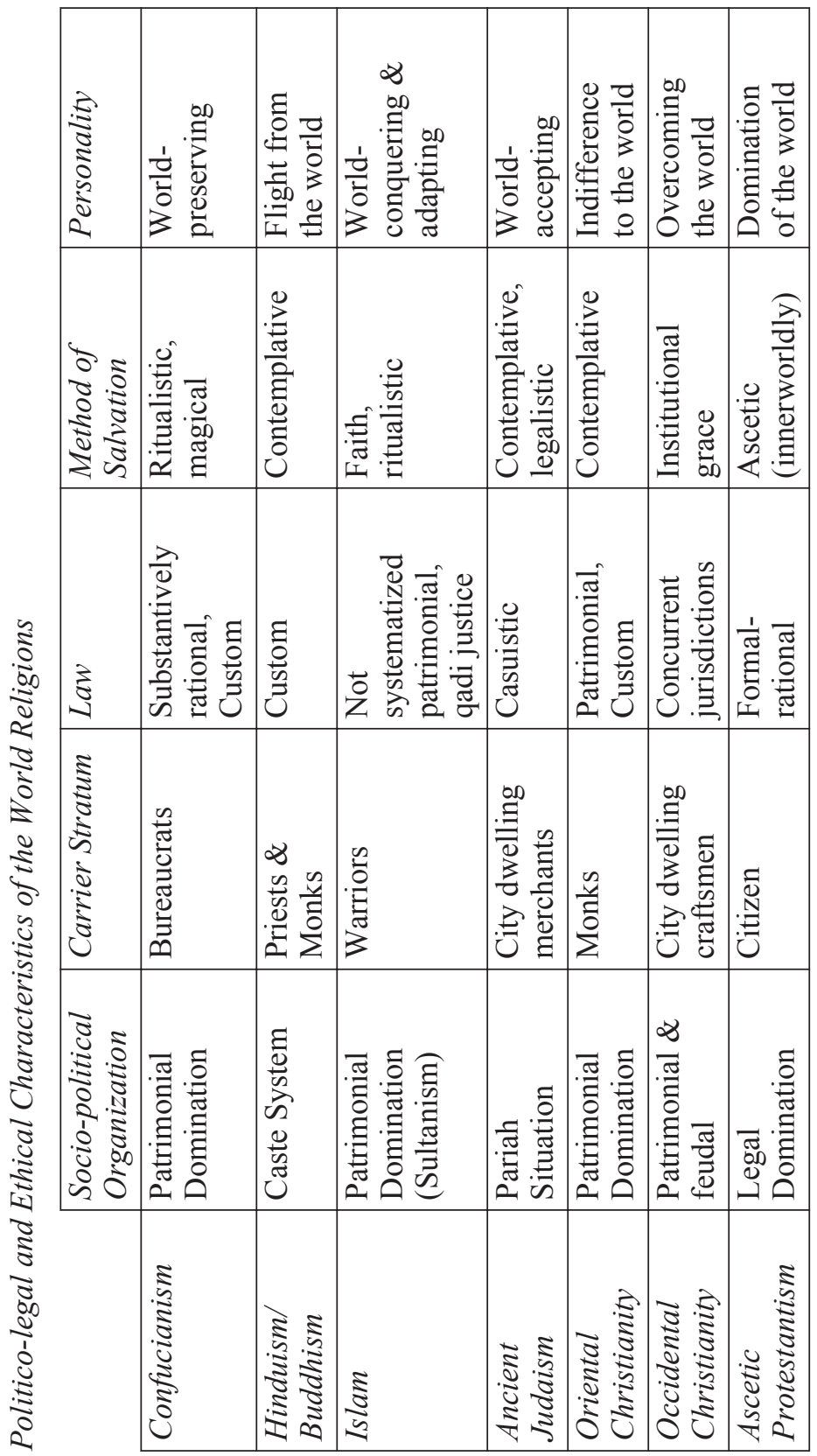




\section{BIBLIOGRAPHY}

Albrow, Martin (1975) «Legal Positivism and Bourgeois Materialism: Max Weber's View of the Sociology of Law» in: British Journal of Law and Society vol. 8, pp 14-31

Aron, Raymond (1967) Les étapes de la pensée sociologique Paris: Gallimard

-, (1969) La philosophie critique de l'histoire Paris: Vrin

Assmann, Jan (1992) Das kulturelle Gedächtnis Munich: C. H. Beck

Baker, J. H. (1971) An Introduction to English Legal History London 1971

Bechert, Heinz (1991) «Max Weber and the Sociology of Buddhism» in: Internationales Asienforum (International Quarterly for Asian Studies) vol. 22, no. 3-4, pp 181-195

Bellah, Robert (1957/1985) Tokugawa Religion New York, London

Berger, Peter (1980) The Heretical Imperative London: Collins

—, (1973) «On the Obsolescence of the Concept of Honour» in: P. Berger The Homeless Mind New York: Vintage pp. 83-96.

Berman, Harold (1983) Law and Revolution Harvard University Press

_, (1996) «The Rule of Law and the Law-Based State» in: W. E. Butler (ed.) Russian Legal Theory Aldershot: Dartmouth Publishing

— \& Charles Reid (2000) «Max Weber as legal historian» in: Stephen Turner (ed.) The Cambridge Companion to Weber Cambridge University Press

Besnard, Philippe (1970) Protestantisme et Capitalisme Paris: Armand Colin

Blake, Stephen (1979) «The Patrimonial-Bureaucratic Empire of the Mughals» in: Journal of Asian Studies 39 (1) pp 77-94

Braun, Christoph (1999) «The «Science of Reality» of Music History: on the Historical Background to Max Weber's Study of Music» in: Sam Whimster (ed.) Max Weber and the Culture of Anarchy London: MacMillan pp 176-195

Breuer, S. \& Treiber, H. (eds.) (1984) Zur Rechtssoziologie Max Webers Opladen

Bühler, G. (1894) «Indische Erbauungsstunden» in:Deutsche Revue über das gesamte nationale Leben der Gegenwart vol. XIX, 4 p 223 sqq, especially p. 227.

_, (transl.) (1967), first published in 1886, The Laws of Manu Delhi: Motilal Banarsidass

Bünger, Karl (1983) «Das chinesische Rechtssystem und das Prinzip der Rechtsstaatlichkeit» in: W. Schluchter Max Webers Studie über Konfuzianismus und Taoismus Frankfurt a. M.: Suhrkamp

Buss, Andreas (1985) Max Weber and Asia München: Weltforum

-, (1989) «The Economic Ethics of Russian-Orthodox Christianity»: Part I in: International Sociology vol. 4, no 3, pp 235-258 
-, (1989) «The Economic Ethics of Russian-Orthodox Christianity: Part II - Russian Old Believers and Sects» in: International Sociology vol. 4, no.4 pp 447-472

-, (2003) The Russian-Orthodox Tradition and Modernity Leiden: Brill

-, (2010) «The Preah Vihear Case and Regional Customary Law» in: Chinese Journal of International Law vol. 9, no. 1 pp 111-126

Chiba, Masaji (1986) Asian Indigenous Law. Interaction with Received Law. London: KPI

Conrad, Dieter (1986) «Max Weber's Conception of Hindu Dharma» in: D. Kantowsky (ed.) Recent Research on Max Weber's Studies of Hinduism London/ München: Weltforum

-, (1999) Zwischen den Traditionen Stuttgart: Fritz Steiner

Coutu, Michel (1995) Max Weber et les rationalités du droit Paris: L.G. D. J.

Dumont, Louis (1966) Homo Hierarchicus. Essai sur le système des castes Paris: Gallimard

—, (1982) «A Modified View of Our Origins. The Beginnings of Modern Individualism» in: Religion 12 pp 1-27

Eckermann. J. P. (1955), originally 1835, Gespräche mit Goethe Wiesbaden: Insel

Eisenstadt, S.N. (2000) «Multiple Modernities» in: Daedalus Winter 2000, pp 1-31

Elon, Menachem (1982) «Law, Jewish» in: Dictionary of the Middle Ages (J. Strayer, ed.) vol. 7

Farris, Sara (2013) Max Weber's Theory of Personality Leiden: Brill

Fei, Hsiao-tung (1992) From the Soil. The Foundations of Chinese Society U. of California Press

Feldbrugge, Ferdinand (2009) Law in Medieval Russia Leiden: Martinus Nijhoff

Fischoff, E. (1968) «The Protestant Ethic and the Spirit of Capitalism: The History of a Controversy» in: S.N. Eisenstadt (ed.) The Protestant Ethic and Modernization New York: Basic Books

Freund, Julien (1978) «La rationalisation du droit selon Max Weber» in: Archives de philosophie du droit vol. 23

—, (1968) «L'éthique économique et les religions mondiales selon Max Weber» in: Archives de sociologie des religions vol 26 pp 3-25

Gephart, Werner (1993) Gesellschaftstheorie und Recht Frankfurt a. M.: Suhrkamp

-, (2010) «Einleitung» in: Max Weber Gesamtausgabe I / 22-3 pp. 1-133

Glasenapp, Helmuth v. (1964) Der Jainismus Hildesheim: Olms

Goitein, S. D. (1957) «The Rise of Near Eastern Bourgeoisie in Early Islamic Times» Journal of World History vol. 3 pp 583-604

Guttmann, Julius (1981), originally 1923, «Max Webers Soziologie des antiken Judentums» in: W. Schluchter Max Webers Studie über das antike Judentum Frankfurt a. M.: Suhrkamp

Hamilton, G. (1984) «Patriarchalism in Imperial China and Western Europe» in: Theory and Society vol. 13, no. 3, 393 sqq. 
Harnack, A. v. (1991) Dogmengeschichte Tübingen: Mohr (Siebeck) (first published in $1889 / 91)$

Hart, H. L. A. \& Honoré, T (1985) Causation in the Law London: Clarendon

Hartmann, W. \& Pennington, K.(eds.) (2012) The History of Byzantine and Eastern Canon Law to 1500 Washington: Catholic University of America Press

Henderson, D.F. (1965) Conciliation and Japanese Law Seattle

Henrich, Dieter (1952) Die Einheit der Wissenschaftslehre Max Webers Tübingen: Mohr (Siebeck)

Hermes. Siegfried (2007) «Staatsbildung durch Rechtsbildung» in: Anter/Breuer (eds.) Max Webers Staatssoziologie Baden-Baden: Nomos

Horner, I. B. (transl.) (1969) Milinda's Questions London: Luzac \& Company

Horton, R. (1979) «African Traditional Thought and Western Science» in: Bryan Wilson (ed.) Rationality Oxford: Basil Blackwell

Huff, Toby \& Schluchter, W. (eds.) (1999) Max Weber and Islam Transaction Publishers

Jaspers, Karl (1949) Vom Ursprung und Ziel der Geschichte München: Piper

Jellinek, Georg (1895) Die Erklärung der Menschen- und Bürgerrechte Leipzig: Duncker \& Humblot

Kaiser, Daniel (1980) The Growth of Law in Medieval Russia Princeton University Press

Kalberg, Stephen (1994) Max Weber's Comparative-Historical Sociology University of Chicago Press

Kantowsky, Detlef (1982) «Max Weber on India and Indian Interpretations of Max Weber» in: Contributions to Indian Sociology (NS) vol 16, no.2 pp 141-174

Kippenberg, Hans (1995) «Max Weber und die vergleichende Religionswissenschaft» in: Revue Internationale de Philosophie 2/1995 - no. 192 pp. 127-153

- , (2005) «Religious Communities and the Path to Disenchantment» in:Camic, Gorski,Trubek (eds) Max Weber's Economy and Society. A Critical Companion pp. 164-182 Stanford University Press

Klibansky, Raymond (1966) «The School of Chartres» in: M. Clagett et al. (eds.) Twelfth Century Europe and the Formation of Modern Society University of Wisconsin Press

Kries, J. von (1888) Über den Begriff der objektiven Möglichkeit Leipzig: Fues's

Kronmann, A. (1983) Max Weber London: Edward Arnold

Lamotte, Étienne (1962) L'enseignement de Vimalakirti Louvain: Publications Universitaires

Leroy-Beaulieu, A. (1990), originally published 1893-97, L'empire des tsars et les Russes Paris: Robert Laffont

Lingat, Robert (1950) «Evolution of the Conception of Law in Burma and Siam» The Journal of the Siam Society

—, (1967) Les sources du droit dans le système traditionnel de l'Inde Paris: Mouton 
Lütt, Jürgen (1987) «The Doctrine of the Vallabhacarya Sect and the Economic Performance of Its Followers» in: International Sociology 2 (3)

Menski, Werner (2003) Hindu Law. Beyond Tradition and Modernity Oxford University Press

-, (2000) Comparative Law in a Global Context London: Platinium

Metzger, Thomas (1977) Escape from Predicament. Neo-Confucianism and China's Evolving Political Culture New York: Columbia University Press

Mommsen, W. \& J. Osterhammel (eds.) (1987) Max Weber and his Contemporaries London: Allen \& Unwin

Morishima, Michio (1982) Why has Japan succeeded? Western Technology and Japanese Ethos Cambridge University Press

Nafissi, Mohammad (1998) «Reframing Orientalism: Weber and Islam» in: Ralph Schroeder (ed.) Max Weber, Democracy, and Modernization London: MacMillan

Needham, Joseph (1969) The Grand Titration London: George Allen \& Unwin

Nestle, Wilhelm (1941) «Die Haupteinwände des antiken Denkens gegen das Christentum» in: Archiv für Religionswissenschaften 37 pp. 51-100

Nevashkar, B. (1991) Capitalists without Capitalism. The Jains of India and the Quakers of the West Westport: Greenwood

Niebuhr, B.G. (ed.) 1828 Corpus Scriptorum Historiae Byzantinae pars XI (Leo Diaconus) Bonn

Orihara, H. (2003) «From a torso with a wrong head to five disjointed body parts without a head» Max Weber Studies 3, 2

Otto, Eckart (2005) «Einleitung» in: Max Weber Gesamtausgabe I / 21-1 (Das antike Judentum) 1-144

Owen, Thomas (1991) The Corporation under Russian Law 1800-1917 Cambridge University Press

Pennington, K. (1998) «Due Process, Community and the Prince in the evolution of the ordo iudiciarius» in: Rivista Internazionale di Diritto Comune vol. 9

Procaccia, Uriel (2007) Russian Culture, Property Rights, and the Market Economy Cambridge

Radbruch, Gustav (1980), originally published in 1913, Einführung in die Rechtswissenschaft Stuttgart: Koehler Verlag

Raphael, Freddy (1973) «Max Weber and Ancient Judaism» in: Leo Baeck Institute Yearbook 18.1

Redding, Gordon (1993) The Spirit of Chinese Capitalism Berlin/New York: de Gruyter

Rheinstein, Max (1954) Max Weber on Law in Economy and Society Harvard University Press

Rickert, Heinrich (1910) Kulturwissenschaft und Naturwissenschaft Tübingen: Mohr (Siebeck)

Rossi, Pietro (1987) «Die Rationalisierung des Rechts und ihre Beziehung zur Wirtschaft» in: Rehbinder, M. \& K.P. Tieck (eds.) Max Weber als Rechtssoziologe Berlin: Duncker \& Humblot 
—, (2003) «Universalgeschichte und interkultureller Vergleich» in: G. Albert, A. Bienfait, S. Sigmund, C. Wendt Das Weber-Paradigma. Studien zur Weiterentwicklung von Max Webers Forschungsprogram Tübingen: Mohr (Siebeck)

Said, Edward (1979) Orientalism New York: Vintage

Sakrani, Raja (2009) Au croisement des cultures de droit occidentale et musulmane. Le pluralisme juridique dans le code tunisien des obligations et des contrats. Hamburg: EB Verlag

Schacht, Joseph (1964) An Introduction to Islamic Law Oxford University Press

Schelting, Alexander von (1934) Max Webers Wissenschaftslehre Tübingen: Mohr (Siebeck) 1934

Schimmel, Annemarie (2000) Sufismus München: Beck

Schluchter, W. (ed.) (1981) Max Webers Studie über das antike Judentum Frankfurt a.M.: Suhrkamp

—, (1983) Max Webers Studie über Konfuzianismus und Taoismus Frankfurt a. M.: Suhrkamp

-, (1984) Max Webers Studie über Hinduismus und Buddhismus Frankfurt a. M.: Suhrkamp

—, (1985) Max Webers Sicht des antiken Christentums Frankfurt a. M.: Suhrkamp

-, (1987) Max Webers Sicht des Islams Frankfurt a. M.: Suhrkamp

-, (1988) Max Webers Sicht des okzidentalen Christentums Frankfurt a. M.: Suhrkamp

—, (1989) Rationalism, Religion, and Domination Berkeley: University of California Press

—, (1996) Paradoxes of Modernity Stanford University Press

-, (2005) Handlung, Ordnung, Kultur Tübingen: Mohr (Siebeck)

—, (2006) Grundlegung der Soziologie, vol. 1, Tübingen: Mohr (Siebeck)

Schroeder, Ralph (1992) Max Weber and the Sociology of Culture London: Sage

Schwentker, Wolfgang (1998) «Western Impact and Asian Values in Japan's Modernization» in: Ralph Schroeder (ed.) Max Weber, Democracy, and Modernization London: MacMillan

Sivin, Nathan (1983) «Chinesische Wissenschaft. Ein Vergleich der Ansätze von Max Weber und Joseph Needham» in: W. Schluchter (ed.) Max Webers Studie über Konfuzianismus und Taoismus

Smith, Wilfred Cantwell (1979) Faith and Belief Princeton University Press

Sombart, Werner (1913) Der Bourgeois Leipzig/Berlin: Duncker \& Humblot

Sprenkel, S. van der (1977) Legal Institutions in Manchu China London

Tenbruck, Friedrich (1980) «The problem of thematic unity in the works of Max Weber» in: British Journal of Sociology vol. 31, 3 pp 316-351

Treiber, Hubert (1985) «Elective Affinities Between Max Weber's Sociology of Religion and Sociology of Law» in: Theory and Society vol. 14

Trubek, D. (1972) «Max Weber on Laws and the Rise of Capitalism» in: Wisconsin Law Review 3 
Troeltsch, Ernst (1969) The Social Teaching of the Christian Churches New York: Harper (originally published in German 1911)

-, (1911) «Das stoisch-christliche Naturrecht und das moderne profane Naturrecht» in: Verhandlungen der Deutschen Soziologentage, vol 1 (Oct. 1910) Mohr (Siebeck) pp. 166-192

Tu, Wei-Ming (1996) «The Confucian Dimension of the East-Asian Development Model» in: Josef Kreiner (ed.) The Impact of Traditional Thought in Present Day Japan München: Judicium

Turner, Bryan (1974) Weber and Islam London: Routledge \& Kegan Paul

-, (1981) For Max Weber. Essays on the Sociology of Fate London: Routledge \& Kegan Paul

Turner, S. \& Factor, R. (1981) «Objective Possibility and Adequate Causation in Weber's Methodological Writings» Sociological Review 29 (1)

Tyrell, Hartmann (1990) «Worum geht es in der 〈Protestantischen Ethik〉 ?» in: Saeculum vol. 41 (2)

Ullmann, Walter (1978) Scholarship and Partisanship in the Middle Ages London: Variorum Reprints

Weber, Marianne (1984/1926) Max Weber. Ein Lebensbild Tübingen: Mohr (Siebeck) (Max Weber. A Biography New York: Wiley 1975)

Weber, Max (1920/21) Gesammelte Aufsätze zur Religionssoziologie vol.1 (1920); vol. 2 (1921) Hinduismus und Buddhismus; vol. 3 Das antike Judentum (1920) Tübingen: Mohr (Siebeck)

—, (1988 / 24) Gesammelte Aufsätze zur Soziologie und Sozialpolitik Tübingen: Mohr (Siebeck)

—, (1988 / 24) Gesammelte Aufsätze zur Sozial- und Wirtschaftsgeschichte Tübingen: Mohr (Siebeck)

-, (1951) The Religion of China New York / London: MacMillan

-, (1958) The Religion of India New York: The Free Press

-, (1958) The Rational and Social Foundations of Music Southern Illinois University Press

-, (1958) From Max Weber: Essays in Sociology. (translated and edited by H.H. Gerth \& C. Wright Mills) New York: Oxford University Press

-, (1967) Ancient Judaism New York: The Free Press

-, (1968) Economy and Society New York: Bedminster Press

-, (1972) Wirtschaft und Gesellschaft Tübingen: Mohr (Siebeck)

-, (1976) The Agrarian Sociology of Ancient Civilization London: New Left Books

-, (1978) Die protestantische Ethik II. Kritiken und Antikritiken Gütersloh: Gerd Mohn

-, (1981) General Economic History New Brunswick: Transaction

-, (1984 - ) Max Weber Gesamtausgabe Tübingen: Mohr (Siebeck)

—, (1994) Max Weber: Political Writings (edited by P. Lassman \& R. Speirs) Cambridge U. Press 
-, (2001) The Protestant Ethic and the Spirit of Capitalism (translated by T. Parsons) London \& New York: Routledge

-, (2001) The Protestant Ethic Debate. Max Weber's Replies to his Critics 1907-1910. (edited \& transl. By D. Chalcraft, A. Harringston \& M. Shields) Liverpool University Press

-, (2002) The Protestant Ethic and the «Spirit» of Capitalism and Other Writings (edited \& transl. by P. Baehr \& G. Wells) London: Penguin

-, (2003) The History of Commercial Partnerships in the Middle Ages Lanham: Rowman \& Littlefield Publishers

-, (2012) Max Weber: Collected Methodological Writings (edited by H. H. Bruun \& S. Whimster; translated by H. H. Bruun) London: Routledge

Winckelmann, J. (1986) Max Webers hinterlassenes Hauptwerk Tübingen: Mohr (Siebeck)

Wiese, Benno von (1989) «Editorial note on Goethe's novel «Die Wahlverwandtschaften»» in: Goethes Werke, Hamburger Ausgabe vol. VI

Williamson, H. R. (1935) Wang An Shih London: Arthur Probsthain

Wright, A. F. (1959) Buddhism in Chinese History Stanford University Press

Zimmer, Heinrich (1951) Philosophy of India Princeton University Press

-, (1972) Myths and Symbols in Indian Art and Civilization Princeton University Press 


\section{INDEX OF AUTHORS}

Italicized numbers refer to the text of footnotes

Albrow, Martin 168, 169

Freund, Julien 164, 172

Aron, Raymond 151

Assmann, Jan 92

Gephart, Werner 173

Glasenapp, H.v. 81

Baker, J.H. 194

Bechert, Heinz 85

Goethe, J. W. v. 36, 40, 73, 138

Bellah, Robert 87

Goitein, S.D. 108

Berger, Peter 52, 131

Berman, Harold 127, 168, 169,

172, 186, 192, 201, 204

Besnard, Philippe 151

Blake, Stephen 106

Braun. Christoph 203

Breuer, Stefan 188

Bühler, Georg 81

Bünger, Karl 175

Guttmann, Julius 182

Hamilton, G. 59

Harnack, A.v. 113

Hart \& Honoré 145

Hartmann, W. \& Pennington 185

Henderson, D.F. 178

Henrich, Dieter 26, 140, 204

Hermes, Siegfried 193

Horner, I.B. 83

Buss, Andreas 115, 116, 120, 149, 192

Horton, R. 64

Huff, Toby 101

Chiba, Masaji 179, 195

Conrad, Dieter 160, 177

Coutu, Michel 169, 170

Dumont, Louis 23, 24, 77, 128 , 177

Jaspers, Karl 49, 92, 204

Jellinek, Georg 189

Jhering, Rudolf v. 35, 194

Kaiser, Daniel 183, 185

Kalberg, Stephen 206

Kantowsky, Detlef 17, 160

Eckermann, J.P. 36

Kippenberg, Hans 21, 48

Eisenstadt, S.N. 138, 196

Klibansky, Raymond 201

Elon, Menachem 182

Kries, J.v. 137, 141 sqq.

Kronman, A. 156, 164, 170

Farris, Sara 197

Fei, Hsiao-tung 174

Lamotte, Étienne 86

Feldbrugge, F. 184

Leroy-Beaulieu, A. 183

Fischoff, E. 138

Lingat, Robert 176, 178 
Lütt, Jürgen 89, 149

Menski, Werner 175/6, 196

Metzger, Thomas 65

Morishima, Michio 87

Nafissi, Mohammad 21

Needham, Joseph 64

Nestle, Wilhelm 113

Nevashkar, B. 81

Niebuhr, B.G. 186

Nietzsche, Friedrich 29, 35, 40, $50,96,151,202$

Orihara, H. 17

Otto, Eckart 101

Owen, Thomas 184

Parsons, Talcott 15, 17, 30, 47

Pennington, K. 187

Pipes, Richard 115

Procaccia, Uriel 184

Radbruch, Gustav 146, 172

Raphael, Freddy 97

Redding, Gordon 66

Rheinstein, Max 153, 156, 164, 168

Rickert, Heinrich 26

Rilke, Rainer Maria 68

Rossi, Pietro 164

Said, Edward 21, 197

Sakrani, Raja 196
Schacht, Joseph 180

Schelting, Alexander v. 150

Schimmel, Annemarie 109

Schluchter, Wolfgang 19, 57, 64, $76,92,98,101,110,127,140$, 196

Schroeder, Ralph 21

Sivin, Nathan 64

Smith, Adam 195

Smith, Wilfred Cantwell 89

Sombart, Werner 98

Sprenkel, S. van der 175

Tenbruck, Friedrich 16

Tocqueville, A. 23

Treiber, Hubert 156

Trubek, D. 156

Troeltsch, Ernst 48, 128, 135

Tu, Wei-Ming 88

Turner, Bryan 108, 168

Turner, Stephen 145, 168

Tyrell, Hartmann 151

Ullmann, Walter 202

Weber, Marianne 20, 23, 74, 111, 140

Winckelmann, J. 16, 42

Wiese, Benno v. 138

Williamson, H.R. 86

Wright, A.F. 86

Zimmer, Heinrich 24, 83 


\section{INDEX OF SUBJECTS}

Italicized numbers refer to the text of footnotes

affinity, elective 19, 30, 44, 137, 205

Anstalt 57, 129, 180, 186, 191, 193

axial age 49,92

Baptists 39

Beruf 36

Bhagavadgita 73,80

Buddhism

_ , ancient Buddhism 82

- , Mahayana 86

bureaucracy

- , modern 59, 114, 192

_ , patrimonial 59, 103, 106, 116

Calvinism 37 sqq., 158

canon law 185

capitalism (general) 26, 45, 59, 91, 92, 110, 137

_ , modern capitalism 136, 198

- , spirit of capitalism 35, 43, 136,138

caste 76 sq.

causation, adequate 140,147

charisma 56,59

- , office charisma 114

church / sect 41, 89, 124

city

_ , in China 63

_ , in India 77

- , in Islam 104

- , , in Japan 88
_ $\quad$, in the Occident 76, 132

_ , in Russia 117

comparative sociology 23, 60

contract 131, 163, 184, 194

corporation 129, 133, 191

- , lacking

in China 175

in India 177

in Islam 180

in Russia 184

disciplina arcani 100, 124

disenchantment 28, 47, 202

dogma / psychological motivation $30,40,45,98,108,155$

Donatists 114

Dukhobors 125

ethnocentrism 22, 23, 197

Eigengesetzlichkeit 53, 70, 79, 159, 160, 166, 167, 190

feudalism $87,103,116,131$

Gegenprobe 151

heterodoxy 61

hierarchy 77,186

ideal type 26, 169

individualism $37,66,81,88,124$, $128,163,184,194$

intellectualism 74, 112 
interest taking 96, 134, 179, 180, 182,184

Jainism 46, 62, 80, 205

Japan 87, 92, 178, 196

Khlysty 51, 124

law

- , canon law 185

- , customary law 186, 192

- English common law 168, 193

- , formal / substantive 163, 189

- , mercantile 132, 191

- , natural law 126, 135, 160, 176, 188

law

_ , in ancient Rome 187

_ , in Buddhism 177

_ , in China 174

_ , in India 176

_ , in Islam 105, 179

_ , in Judaism 181

_ , in Russia 183

Lingayats 88

liturgy $111,117,183$

magic 49, 63, 65, 94, 99

miracle 91,94

Molokans 126

music 19, 203

mysticism/ asceticism 37, 68 sq., 72,120

orientalism 21, 197

Old Believers 62, 121

Pandectists 163, 190

Papal Revolution 129, 205 pariah ethic 96, 123

pariah people 95

Parsis 81,124

patrimonialism $56,58,102,116$

personality 28, 43, 66, 92, 197

Pharisees 98

prophecy, exemplary / emissary

$52,82,94,157$

psychological motivation / ethics

$30,40,45,98,108,155$

Quaker 39

rationality (in general) 20, 27, 55, 199

rationalisation of law 160 ,

- , of religion 65,159

Rechtsstaat 132, 192

science

- , in China 64

_ , in India 79

_ , in Islam 180

- , in the Occident 201

- , in Russia 121, 184

Shivaism 89

Sikhism 90

Skoptsy 46, 124, 205

spirit / system 29, 42, 139

Sufism 106, 108

Taoism 62

theodicy $47,48,51,75,158$

Vallabhacarins 89, 149

verstehen 139, 140

Vishnuism 89

Zoroastrianism 50, 75 